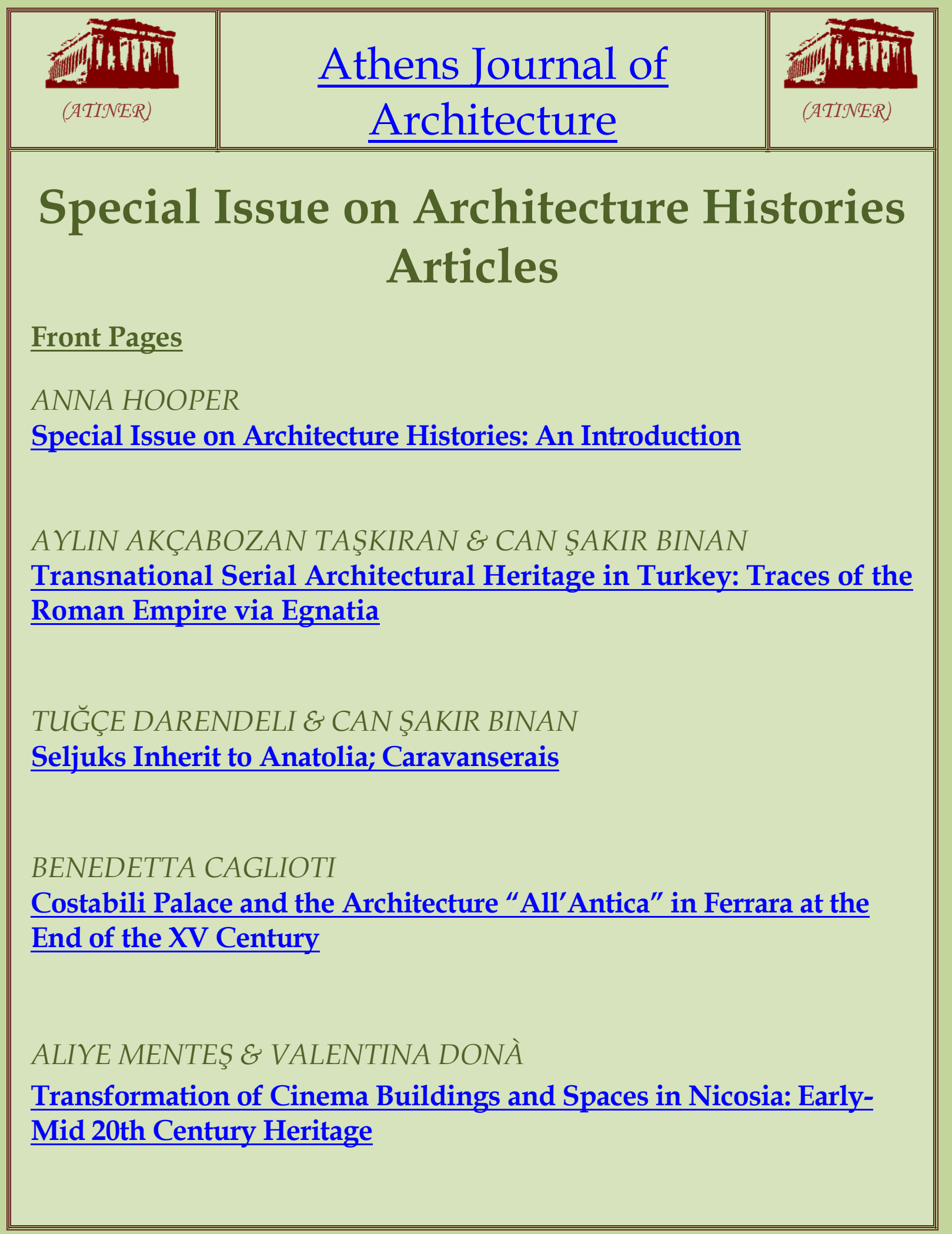




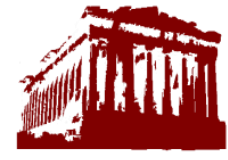

Established in 1995

(ATINER)

\section{Mission}

ATINER is an Athens-based World Association of Academics and Researchers based in Athens. ATINER is an independent and non-profit Association with a Mission to become a forum where Academics and Researchers from all over the world can meet in Athens, exchange ideas on their research and discuss future developments in their disciplines, as well as engage with professionals from other fields. Athens was chosen because of its long history of academic gatherings, which go back thousands of years to Plato's Academy and Aristotle's Lyceum. Both these historic places are within walking distance from ATINER's downtown offices. Since antiquity, Athens was an open city. In the words of Pericles, Athens"... is open to the world, we never expel a foreigner from learning or seeing". ("Pericles' Funeral Oration", in Thucydides, The History of the Peloponnesian War). It is ATINER's mission to revive the glory of Ancient Athens by inviting the World Academic Community to the city, to learn from each other in an environment of freedom and respect for other people's opinions and beliefs. After all, the free expression of one's opinion formed the basis for the development of democracy, and Athens was its cradle. As it turned out, the Golden Age of Athens was in fact, the Golden Age of the Western Civilization. Education and (Re)searching for the 'truth' are the pillars of any free (democratic) society. This is the reason why Education and Research are the two core words in ATINER's name. 
The Athens Journal of Architecture

ISSN NUMBER: 2407-9472- DOI: 10.30958/aja

Special Issue on Architecture Histories

Download the entire issue $(\underline{\mathrm{PDF}})$

Front Pages $\quad$ i-viii

Special Issue on Architecture Histories: An Introduction 113 Anna Hooper

Transnational Serial Architectural Heritage in Turkey: 117 Traces of the Roman Empire via Egnatia Aylin Akçabozan Taşkiran \& Can Şakir Binan

Seljuks Inherit to Anatolia; Caravanserais

Tuğçe Darendeli \& Can Şakir Binan

Costabili Palace and the Architecture "All'Antica" in

Ferrara at the End of the XV Century

Benedetta Caglioti

Transformation of Cinema Buildings and Spaces in

Nicosia: Early-Mid 20th Century Heritage

Aliye Menteş \& Valentina Donà 


\section{Athens Journal of Architecture Editorial and Reviewers' Board}

Editor

- Dr. Nicholas N. Patricios, Vice President of Strategic Planning \& Analysis, ATINER and Professor \& Dean Emeritus, School of Architecture, University of Miami, USA.

\section{Co-Editors}

- Dr. Clara Germana Gonçalves, Head, Architecture Unit, ATINER \& Researcher, CITAD (Centro de Investigação em Território, Arquitectura e Design), Lusíada University and Associate Professor, ISMAT (Instituto Superior Manuel Teixeira Gomes), Portugal.

- Dr. Fatih Rifki, Academic Member, ATINER \& Professor, Montana State University, USA.

- Dr. Jesus J. Lara, Academic Member, ATINER \& Associate Professor, The Ohio State University, USA.

- Dr. Giulia Pellegri, Vice Dean \& Associate Professor, Architecture-Polytechnic School, University of Genoa, Italy.

\section{Editorial Board}

- Dr. Arthur Chen, Academic Member, ATINER \& Director, Center for World Heritage Studies, School of Architecture, University of Minnesota, USA.

- $\quad$ Dr. Fatih A. Rifki, Professor, Montana State University, USA.

- Dr. Nico Kotze, Professor, University of Johannesburg, South Africa.

- $\quad$ Dr. Eren Erdener, Professor Emeritus, The University of Oklahoma, USA.

- $\quad$ Dr. William Douglas, Professor \& Associate Dean, College of Art \& Design, Louisiana State University, USA.

- Dr. Angus Shuenn-Ren Liou, Professor \& Vice Dean, College of Planning and Design, National Cheng Kung University, Taiwan.

- Dr. Vimolsiddhi Horayangkura, Professor, Faculty of Architecture and Planning, Thammasat University, Thailand.

- Dr. Stefania Mornati, Professor, Department of Civil Engineering and Computer Science Engineering, University of Rome, Italy.

- Mr. Ryadi Adityavarman, Associate Professor, Kansas State University, USA.

- Dr. David A. Badillo, Associate Professor, City University of New York, USA.

- $\quad$ Dr. Wah Sang Wong, Associate Professor, Department of Architecture, The University of Hong Kong, Hong Kong.

- $\quad$ Dr. Milica Muminovic, Assistant Professor, University of Canberra, Australia.

- $\quad$ Dr. Levent Kara, Assistant Professor, School of Architecture and Community Design, University of South Florida, USA.

- $\quad$ Dr. Nik Nikolov, Assistant Professor, Lehigh University, USA.

- $\quad$ Dr. Zeynep Akture, Assistant Professor, Izmir Institute of Technology -Department of Architecture, Turkey.

- Dr. François Blanciak, Lecturer, Faculty of Architecture, Design and Planning, University of Sydney, Australia.

- $\quad$ Dr. Nick McCullen, Lecturer, Department of Architecture and Civil Engineering, University of Bath, UK.

- Dr. Gehan Selim, Lecturer, School of Architecture, Planning and Civil Engineering, Queens' University Belfast, United Kingdom.

- $\quad$ Dr. Anna Hooper, Tutor/Researcher, Melbourne School of Design, University of Melbourne, Australia.

- Dr. Ana Peric, Lecturer \& Chair of Spatial Development, Institute for Spatial and Landscape Development, ETH Zurich.

- Dr. Kees Doevendans, Researcher, Department of the Built Environment, Technical University of Eindhoven, The Netherlands.

- $\quad$ Dr. Carlos Alberto Tello, Postdoctoral Fellow, University of Montreal, Canada.

- General Managing Editor of all ATINER's Publications: Ms. Afrodete Papanikou

- ICT Managing Editor of all ATINER's Publications: Mr. Kostas Spyropoulos

- Managing Editor of this Journal: Ms. Olga Gkounta (bio)

\section{Reviewers' Board}

Click Here 


\section{President's Message}

All ATINER's publications including its e-journals are open access without any costs (submission, processing, publishing, open access paid by authors, open access paid by readers etc.) and is independent of presentations at any of the many small events (conferences, symposiums, forums, colloquiums, courses, roundtable discussions) organized by ATINER throughout the year and entail significant costs of participating. The intellectual property rights of the submitting papers remain with the author. Before you submit, please make sure your paper meets the basic academic standards, which includes proper English. Some articles will be selected from the numerous papers that have been presented at the various annual international academic conferences organized by the different divisions and units of the Athens Institute for Education and Research. The plethora of papers presented every year will enable the editorial board of each journal to select the best, and in so doing produce a top-quality academic journal. In addition to papers presented, ATINER will encourage the independent submission of papers to be evaluated for publication.

The current issue is a Special Issue on Architecture Histories of the Athens Journal of Architecture (AJA), published by the Architecture Unit of ATINER. 


\section{Athens Institute for Education and Research}

\section{A World Association of Academics and Researchers}

\section{$11^{\text {th }}$ Annual International Conference on Architecture}

5-8 July 2021, Athens, Greece

The Architecture Unit of ATINER, will hold its 11 $1^{\text {th }}$ Annual International Conference on Architecture, 5-8 July 2021, Athens, Greece sponsored by the Athens Journal of Architecture. The aim of the conference is to bring together academics and researchers from all areas of Architecture. You may participate as stream organizer, presenter of one paper, chair a session or observer. Please submit a proposal using the form available (https://www.atiner.gr/2021/FORM-ARC.doc).

\section{Academic Member Responsible for the Conference}

- Dr. Nicholas N. Patricios, Vice President of Strategic Planning \& Analysis, ATINER and Professor \& Dean Emeritus, School of Architecture, University of Miami, USA.

- Dr. Clara Germana Gonçalves, Head, Architecture Unit, ATINER \& Researcher, CITAD (Centro de Investigação em Território, Arquitectura e Design), Lusíada University and Associate Professor, ISMAT (Instituto Superior Manuel Teixeira Gomes), Portugal.

- Dr. Fatih Rifki, Academic Member, ATINER \& Professor, Montana State University, USA.

- Dr Anna Hooper, Academic Member, ATINER, Coordinator, Lecturer, Lead Tutor, Ormond College and Melbourne School of Design, The University of Melbourne, Australia.

- Dr. Maria João Dos Reis Moreira Soares, Academic Member, ATINER \& Associate Professor, Lusiada University Lisbon, and Research Fellow, CITAD - Research Centre on Territory, Architecture \& Design, Portugal.

- Abstract Submission: 8 March 2021

\section{Important Dates}

- Acceptance of Abstract: 4 Weeks after Submission

- Submission of Paper: 7 June 2021

\section{Social and Educational Program}

The Social Program Emphasizes the Educational Aspect of the Academic Meetings of Atiner.

- Greek Night Entertainment (This is the official dinner of the conference)

- Athens Sightseeing: Old and New-An Educational Urban Walk

- Social Dinner

- Mycenae Visit

- Exploration of the Aegean Islands

- Delphi Visit

- Ancient Corinth and Cape Sounion

More information can be found here: https://www.atiner.gr/social-program

\section{Conference Fees}

Conference fees vary from $400 €$ to $2000 €$

Details can be found at: https://www.atiner.gr/2021fees 


\section{Athens Institute for Education and Research}

\section{A World Association of Academics and Researchers}

\section{$1^{\text {th }}$ Annual International Conference on Urban Studies \& Planning, 31 May \& 1-3 June 2021, Athens, Greece}

The Architecture Unit in collaboration with the Social Sciences Division of the ATINER will organize its 11 $^{\text {th }}$ Annual International Conference on Urban Studies \& Planning, 31 May \& 1-3 June 2021, Athens, Greece sponsored by the Athens Journal of Architecture. The aim of the conference is to bring together academics and researchers from all areas of social sciences such as urban sociology, urban geography, urban design, urban planning, architecture, etc. You may participate as stream leader, presenter of one paper, chair of a session or observer. Please submit a proposal using the form available (https://www.atiner.gr/2021/FORM-PLA.doc).

\section{Important Dates}

- Abstract Submission: 19 April 2021

- Acceptance of Abstract: 4 Weeks after Submission

- Submission of Paper: 3 May 2021

\section{Academic Members Responsible for the Conference}

- Dr. Nicholas N. Patricios, Vice President of Strategic Planning \& Analysis, ATINER and Professor \& Dean Emeritus, School of Architecture, University of Miami, USA.

- Dr. Virginia Sisiopiku, Head, Transportation Engineering Unit, ATINER, \& Associate Professor, The University of Alabama at Birmingham, USA.

- Dr. Jesus J. Lara, Academic Member, ATINER \& Associate Professor, The Ohio State University, USA.

- Dr. Giulia Pellegri, Associate Professor, Architecture-Polytechnic School, University of Genoa, Italy.

\section{Social and Educational Program}

The Social Program Emphasizes the Educational Aspect of the Academic Meetings of Atiner.

- Greek Night Entertainment (This is the official dinner of the conference)

- Athens Sightseeing: Old and New-An Educational Urban Walk

- Social Dinner

- Mycenae Visit

- Exploration of the Aegean Islands

- Delphi Visit

- Ancient Corinth and Cape Sounion

More information can be found here: https://www.atiner.gr/social-program

\section{Conference Fees}

Conference fees vary from $400 €$ to $2000 €$

Details can be found at: https://www.atiner.gr/2021fees 



\section{Special Issue on Architecture Histories: An Introduction}

\section{By Anna Hooper*}

It is my pleasure to write the introduction for this special issue of the Athens Journal of Architecture 2021 which has arisen from the Architectural History Stream at the $9^{\text {th }}$ Annual International Conference on Architecture held in Athens between 8-11 July, 2019. Papers delivered in this stream, for which I was Chair at the conference, offered insights into architectural design praxis from the ancient Roman period, Medieval and Renaissance times, and more recently, the $20^{\text {th }}$ century. Of these, 3 papers were selected, and 1 from the $8^{\text {th }}$ Annual International Conference on Architecture, for this issue. The researchers of these papers analysed architectural exemplars with differing typologies and contexts yet each shares a common theme of culture, people, and place.

History as a discipline holds an important place in academic research and it is through such research into historic precedents that we, as architects, historians, and educators, can better understand the influences and legacies of architectural sites and buildings and, indeed, what inspired their own development, style and form, and the impact of these on society and culture at a particular point in time.

This is not a new idea. Indeed, in the earliest extant Western treatise we have about architecture (written in the $1^{\text {st }}$ century BC) by the Roman engineer-cumarchitect, Vitruvius, he states that the architect "...should know a great deal of history...". In 1959, the American architect, Philip Johnson told his architecture students "[y] ou cannot today not know history." 2 There have been myriad writers and practitioners of architecture (and related disciplines) spanning the 2 millennia between these two men including Alberti, Quatremere de Quincy, and Ruskin, to name but a few, who have not only drawn upon histories but argued for the importance of them in understanding the built environment.

As an educator in architecture (and landscape architecture) history and design, I am often confronted by students who say "why do I have to know about the past? Why do I have to read about architecture from hundreds, and sometimes thousands, of year ago? I just want to design buildings for the present and for the future" and my answer is this: we learn from history; we learn about how we have come to be where we are now and what lessons we can take with us from history into the future. I say to them: "you need to understand not just what a building from the past looked like and functioned as but also how and why it came into being". History provides context and context is essential; not just physical, tangible, context (as some of my students would argue) but also the intangible, the fragments of ideas and practices long forgotten or buried under the asphalt of contemporary design thinking. Histories serve not only to define and inform, but also to maintain, culture, people and place.

\footnotetext{
*Academic Teaching Member, Melbourne School of Design (MSD), University of Melbourne, Australia.

1. Vitruvius, De Architectura libra decem, (trans.) Ingrid D Rowland (Cambridge, Cambridge University, 1999), Book 1: Chapter 1.

2. Philip Johnson, Writings (Oxford: Oxford University Press, 1979), 108.
} 
This is necessary so we can know how to proceed in the future whether this is designing greenfield sites, redeveloping brownfield sites, applying for a heritage listing, conserving a heritage site or building, or even theorising about architectural form and function. This requires reading and critically analysing the material available to us and arriving at an informed position about the value of a site, a building (or ruin) or even an idealised, but never realised, architectural plan. At the end of semester, my students (most of them anyway) say to me: "Ah, now I get it! I can see why this building has influenced so many others or how this architect has inspired a new Movement". This is why I believe architecture histories are relevant in research; they enrich rather than diminish our understanding, that is, they allow us to examine and critique design thinking and design practice and learn from these insights.

The four papers presented here follow a loose chronology and each explores a discreet aspect of architectural design (and one could argue, architectural engineering in some instances): the heritage significance of a Roman road (via Egnatia) that traversed Europe; the travelling Seljuk caravanserai of Anatolia and the infrastructure (khans) that provided accommodation and sites of exchange; a Renaissance courtyard palace typology (All'Antica) in Ferrara, Italy; and the cinemas and their socio-architectural importance in Nicosia, Cyprus.

Co-authors of the first paper, Aylin Akçabozan Taşkiran \& Can Şakir Binan "aim to provide a framework for... a single hybrid heritage..." in their paper on serial heritage listing in which they examine the extensive ancient Roman road/trade route which traversed a Europe from Illyricum (a Roman province) to what is today the European side of modern-day Turkey. The implications for inclusion under the new World Heritage System Transnational Serial Nominations, is argued as a cultural as well as an architectural imperative.

In the second paper, the authors Tuğçe Darendeli \& Can Şakir Binan analyse the "...change of the commercial activities and accommodations during the history and the spatial organisation, plan typologies and functions of the Anatolian Seljuk Caravanserai constructions...,". " The discussion around the cultural and architectural 'crossroads' in this historical 'roadmap' reveals a new spatial 'Seljuk' form and continues the theme of roads and trade/cultural routes.

Benedetta Caglioti, author of the third paper, takes a different narrative road, one to Ferrara, and examines the "...linguistic, lexical intention... of the Renaissance court palazzo..." in Ferrara and speculates on the culturally-laden language of this exemplar but frames the critique through the broader lens of the Renaissance architects' interest in antiquity.

Concluding this special issue, the final paper by Aliye Menteş \& Valentina Donà states "...the purpose [of the research] is to raise awareness on [the]

3. Aylin Akçabozan Taşkiran and Can Şakir Binan, Transnational Serial Architectural Heritage in Turkey: Traces of the Roman Empire via Egnatia (Abstract) paper presented at ATINER's 11th Annual International Conference on Architecture July 5-8, 2019.

4. Tuğçe Darendeli and Can Şakir Binan, Seljuks Inherit to Aatolia: Caravanserai (Abstract) paper presented at ATINER's 11th Annual International Conference on Architecture July 5-8, 2019.

5. Benedetta Caglioti, Costabili Palace and the Architecture "All'Antica" in Ferrara at the End of the XV Century (Abstract) paper presented at ATINER's 11th Annual International Conference on Architecture July 5-8, 2019. 
significance of cinema buildings thus to foster their protection and enhancement. ... also to stress the role of Cypriot architecture and architecture in the international panorama within the Mediterranean area in a peculiar multicultural context." Through a qualitative research enquiry the authors present the case for such places (and spaces) of socio-cultural importance to be recognised as having real heritage value and that protection should be afforded to reduce further loss of this typology in the region.

As architecture paradigms continue to shift and evolve, the role of histories must always be present as part of the practice of analysis. Without contextual histories, architecture remains in a virtual space without boundaries. The trajectory of architecture from ancient times to the present and into the future is an exciting one and it is the task of the architect not only to design but to reveal these histories. My hope is this will be the first of many special issues on architectural histories in the Athens Journal of Architecture and that it will stimulate further discussion and debate.

\section{Bibliography}

Caglioti, Benedetta. Costabili Palace and the Architecture "All'Antica" in Ferrara at the End of the XV Century. Paper presented at ATINER's $11^{\text {th }}$ Annual International Conference on Architecture July 5-8, 2019.

Darendeli, Tuğçe and Can Şakir Binan. Seljuks Inherit to Anatolia: Caravanserai. Paper presented at ATINER's $11^{\text {th }}$ Annual International Conference on Architecture July 58, 2019.

Johnson, Philip. Writings. Oxford: Oxford University Press, 1979.

Menteş, Aliye and Valentina Donà. Transformation of Cinema Buildings and Spaces in Nicosia: Early-Mid 20 ${ }^{\text {th }}$ Century Heritage. Paper presented at ATINER's $11^{\text {th }}$ Annual International Conference on Architecture July 5-8, 2019.

Taşkiran, Aylin Akçabozan and Can Şakir Binan. Transnational Serial Architectural Heritage in Turkey: Traces of the Roman Empire via Egnatia, paper presented at ATINER's 11th Annual International Conference on Architecture July 5-8, 2019

Vitruvius. De Architecture libri decem. (10 Books on Architecture). Translated by Ingrid D Rowland. Cambridge: Cambridge University Press, 1999.

6. Aliye Menteş and Valentina Donà, Transformation of Cinema Buildings and Spaces in Nicosia: Early-Mid 20th Century Heritage (Abstract) paper presented at ATINER's 11th Annual International Conference on Architecture July 5-8, 2019. 



\title{
Transnational Serial Architectural Heritage in Turkey: Traces of the Roman Empire via Egnatia
}

\author{
By Aylin Akçabozan Taşkiran * \& Can Şakir Binan ${ }^{ \pm}$
}

The term "Transnational Serial Property" generally refers to expansive World Heritage sites, which extend across the territory of two or three UNESCO Convention member states. Transnational serial properties provide various cultural and natural qualities as well as a number of local, regional and national series of nominations in World Heritage. Serial Nominations consist of more components that developed jointly in cultural connections. Each individual element is not only in unique universal value, but also the series as whole have the cultural integrity. However, in today's world, the speed of globalization creates severe problems on World Heritage areas such that the current trends unfortunately suggest an increasing depreciation through existing cultural heritage. There are numerous potential Transnational Serial World Heritage properties in Turkey, many of existing cultural routes. At this point, by highlighting the need for re-evaluation of traces of the Roman Empire as a Transnational Serial architectural heritage, this paper explains the critical discussion of World Heritage areas which should be evaluated as a Serial Transnational Architectural Heritage. An example of this is the Via Egnatia, a road constructed by the Romans in the $2^{\text {nd }}$ century $B C$, was the first Roman highway to be built east of the Adriatic. It passes through the Roman provinces of Illyricum, Macedonia, and Thrace, running through territory that is now part of modern Albania, the Republic of Macedonia, Greece, and European Turkey. The research study aims to provide a framework for the Transnational Serial World Heritage properties in general and mainly focuses on traces of the Roman Empire and cultural routes. Within the context of the cultural routes, Via Egnatia and the need for evaluation as a serial hybrid heritage by concerning preservation of historical, archeological and other values will be discussed. Connected to the information gathered, the paper finalized with a summary on Transnational Serial Nomination system and the transformation of the historical road as a cultural and communicational connection from past to present.

\section{Introduction}

Terminology

- ICOMOS and its International Committee on Cultural Routes invest great efforts to define the concept of cultural route. ${ }^{1}$ Emphasis is placed on the following key features of the concept:

- Cultural route is a traditional way, materially determinated historical track;

- Cultural route matches a certain historical purpose and function;

*Research Assistant, Yildiz Technical University, Turkey.

\pm Professor, Yildiz Technical University, Turkey.

1. International Charter on Cultural Routes, Quebec, 2008. 
- Cultural itinerary includes tangible and intangible cultural phenomena;

- Cultural Routes integrate spiritual and economic relations, environmental and cultural values into comprehensive cultural tourism systems. With these characteristics, cultural routes creates in historical territories conditions for the application of the principle of "competitive cluster" 2 as a basis for sustainable regional development of different sectors related to tourism.

- Cultural roads are kind of cultural heritage, which is evidence of exchange in space and time; demonstrate the role of culture in society. They are not just communication, not just "tourist product" and are a type of heritage associated with memory. ${ }^{3}$

Transnational Serial Nominations: The term Transboundary Properties generally refers to expansive World Heritage sites, which extend as a cohesive and closed area across the territory of two or three UNESCO Convention member states. ${ }^{4}$ Serial entries consist of two or more subcomponents that have arisen and developed jointly in cultural, social or functional terms, and which are linked by clearly defined connections. Each component should be clearly distinguishable and should contribute to the Outstanding Universal Value (OUV) of the property (including possible immaterial attributes) (Transnational Serial Nominations for the UNESCO World Heritage List). The Operational Guidelines (paragraph 19) provides for the inscription of Serial Nominations on the World Heritage List. A serial nomination is any nomination which consists of two or more unconnected areas. $^{5}$

A single World Heritage nomination may contain a series of cultural and/or natural properties in different geographical locations, provided that they are related because they belong to: (i) the same historico-cultural group; (ii) the same type of property which is characteristic of the geographical zone; or (iii) the same geological, geomorphological formation, the same biogeographic province, or the same ecosystem type, and provided that it is the series, and not necessarily each of its components taken individually, which is of outstanding universal value. ${ }^{6}$

2. A competitive cluster may be defined as a grouping of companies, training centres, and public or private research units in a given geographical area, committed to a partnership-based approach intended to generate synergies in relation to common projects of an innovative natüre (www.clusters.wallonie.be).

3. International Charter on Cultural Routes, Quebec, 2008.

4. IUCN, Guidelines for Protected Area Management Categories (Gland, Switzerland and Cambridge, UK: CNPPA with the assistance of WCMC. IUCN, 1994).

5. The Operational Guidelines, 2013.

6. UNESCO, Guidelines for the Preparation of Serial Nominations to the World Heritage List (UNESCO World Heritage Center, 2001). 
Via Egnatia as a Cultural Route

The Via Egnatia, the Roman road built $130 \mathrm{BC}$, from the Adriatic coast to Byzantium; named after the proconsul in Macedonia Cn. Egnatius (AE1973, 492), the Via Egnatia was the main route from Rome to the east. Two branches of the road, starting respectively from Dyrrhachium and Apollonia, united in the Skumbi valley, crossed the Balkan range by Lake Lychnidus (now Ochrid), and descended to Thessalonica by way of Heraclea, Eordaea, Aegae, and Pella, then it followed the Thracian coast to Byzantium. Also, it followed the line of a trade-route through the Balkan range which Corinth had exploited. ${ }^{7}$

The Via Egnatia is a continuation of Via Appia, which starts from Rome and reaches to Brindisi. This road from Brindisi goes by sea to Apollonia and Dıraç goes from here to the East by land. The important cities where Via Egnatia passes along this route are Mirake (Albania) (Figure 3), Dyrrachium - Dıraç Thessaloniki(Selanik), Amphipolis, Neapolis (Kavala), Phillippi, Abdera, Maronea, Traianoupolis, Kypsela (Ipsala), Ainos (Enez), Rhaidestos (Tekirdağ), Perinthos (Marmara) Ereğlisi, Selymbria (Silivri), Byzantion (Istanbul) (Figure 1-2). According to Holdich, about 168 B.C. a road was commenced which ultimately connected old Rome with new Rome (Constantinople), called the Via Egnatia. This road started from Durazzo on the Adriatic coast and passed by Ochrida, Monastir, Salonika, and Kavala to Perinthus (then rivalling Byzantium), and continued to Armenia and Persia. Then followed the road connecting Monastir with Sofia and the Danube. ${ }^{8}$

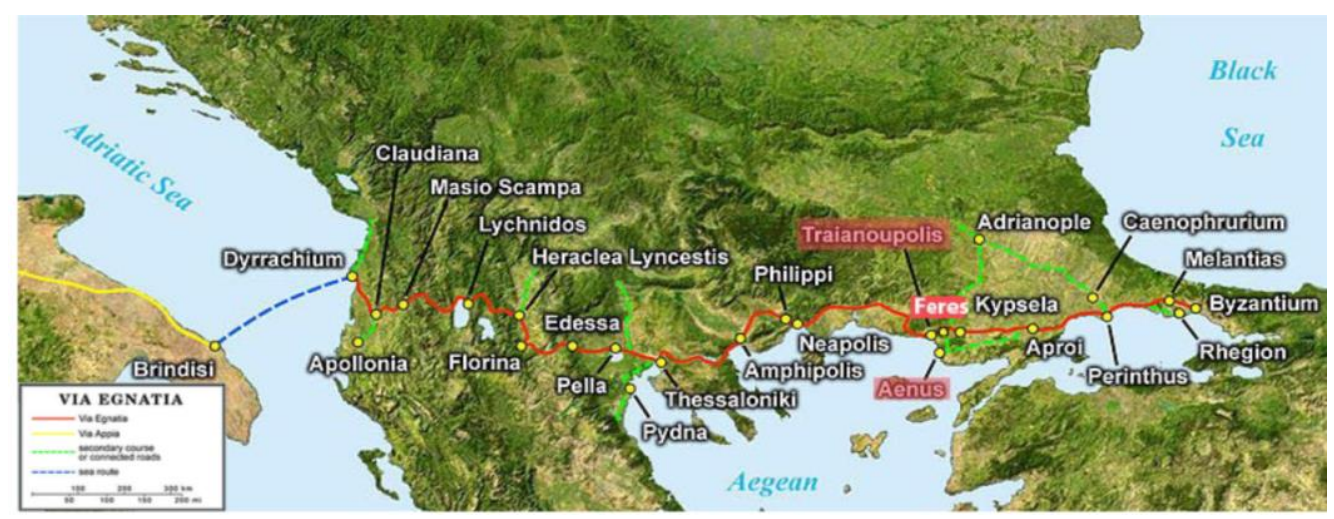

Figure 1. Route of the Via Egnatia

Source: Gaba and Sting, 2006.

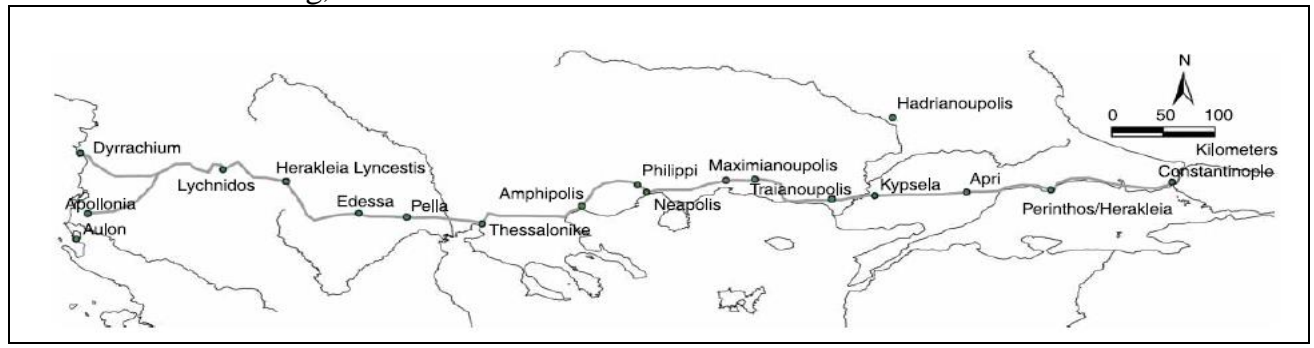

Figure 2. Via Egnatia Schematic Reconstruction

Source: Lolos, Via Egnatia after Egnatius: Imperial Policy and Inter-regional Contacts, 2007.

7. N. Geoffrey and L. Hammond, Subject: Ancient Geography, 2016.

8. T. Holdich, Boundaries in Europe and the Near East (London: Macmillan and Co., 1918). 

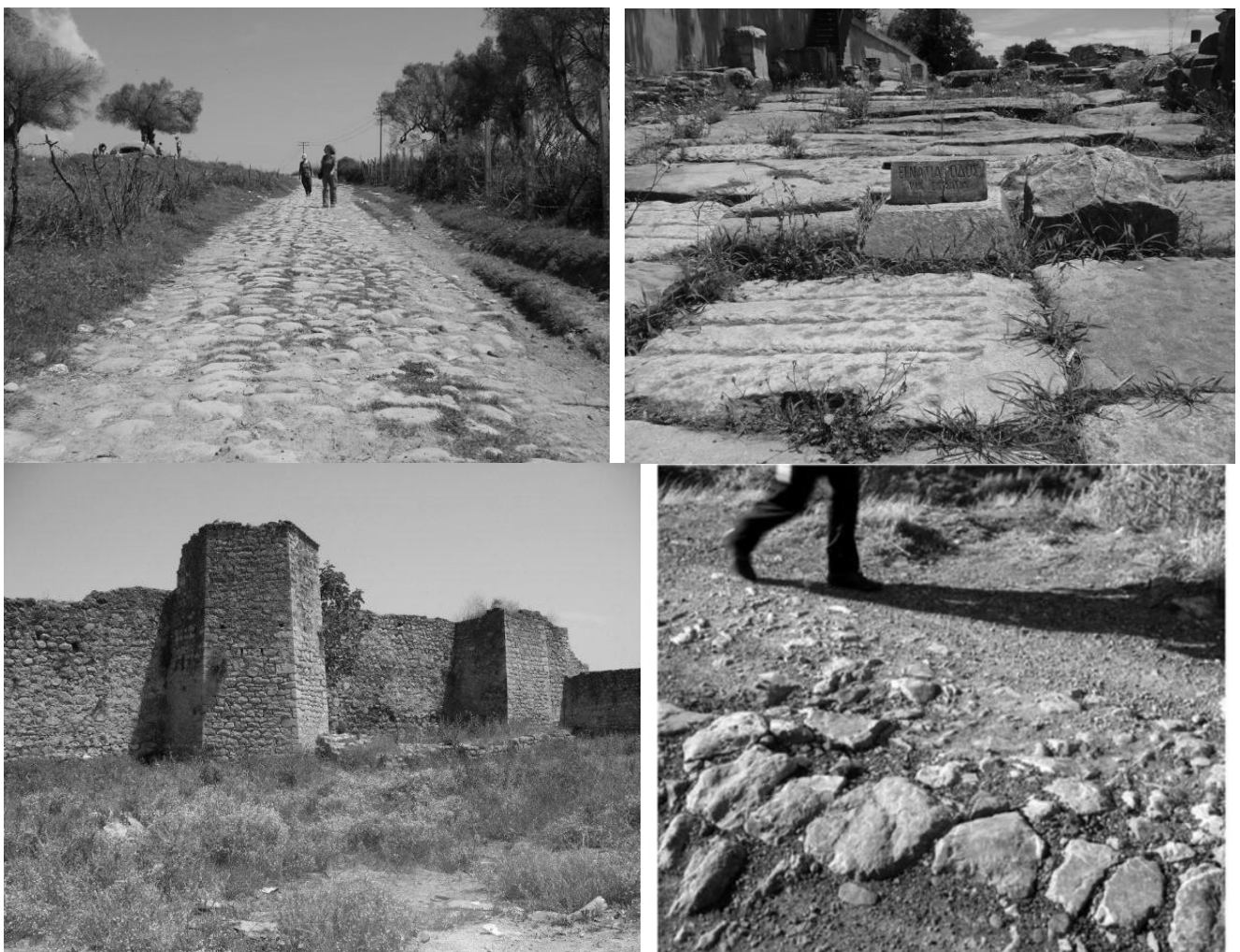

Figure 3. Via Egnatia Still Shows Roman Paving Stones, such as These near Mirakë in Eastern Albania

Source: Url-2.

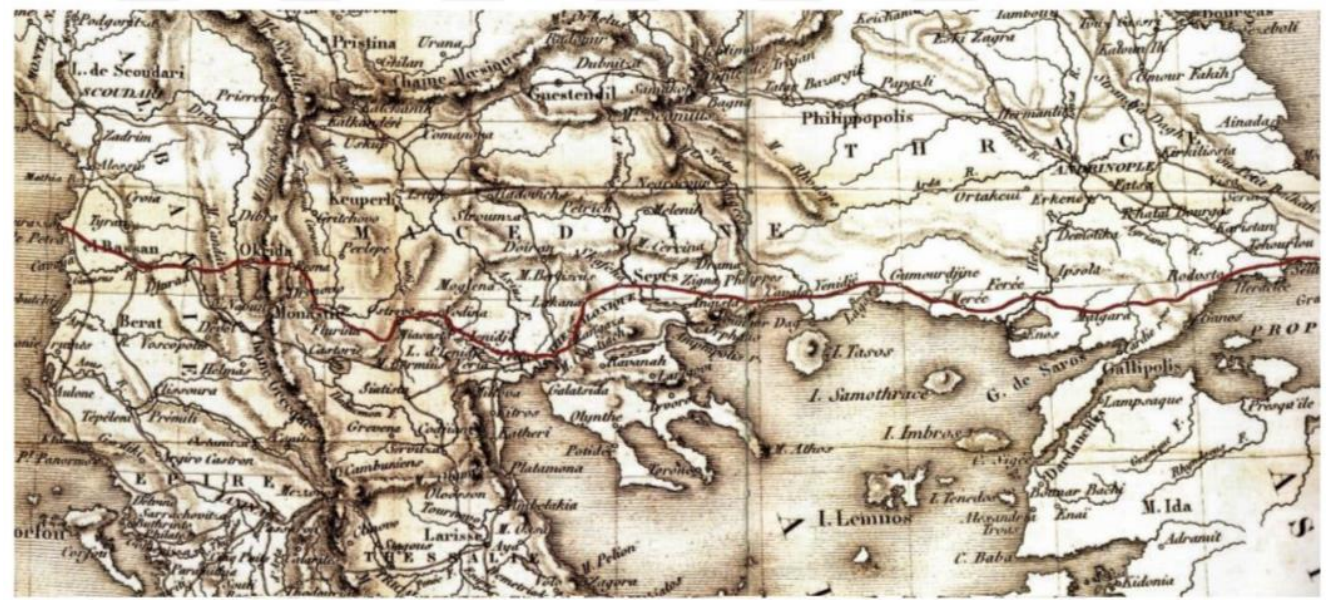

Figure 4. Thrace and Via Egnatia, $19^{\text {th }}$ Century Map

Source: Url-3.

The general route of the road, however, is not difficult to discern, and would have closely matched with the existing highway to Istanbul today, covering a distance of approximately 320 kilometers between Edirne and Istanbul. ${ }^{9}$ It is described as, the road from Adrianople to Constantinople via Silivri follows the natural line of approach to the capital, avoiding Istrandja Mountains to the North,

9. Great Britain Naval Intelligence Division, Handbook of Turkey, 283. 
and largely following the course of the Ergene River, a majör tributary of the Maritsa (Figure 4). ${ }^{10}$

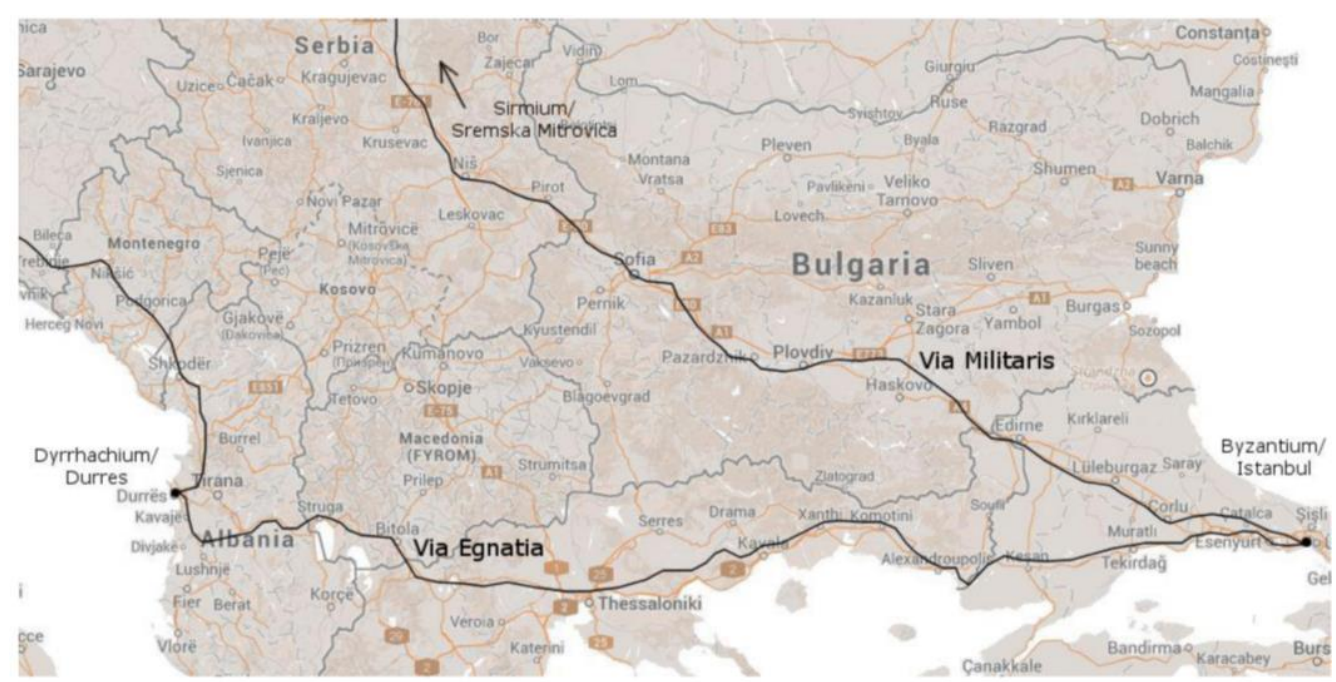

Figure 5. Present and Ancient Roman Roads in Bulgaria, Turkey, Greece, Macedonia and Albania

Source: Ancient World Mapping Center, Talbert, 2000; Deluka et al., 2003; Dzino, 2010; Google Maps Engine.

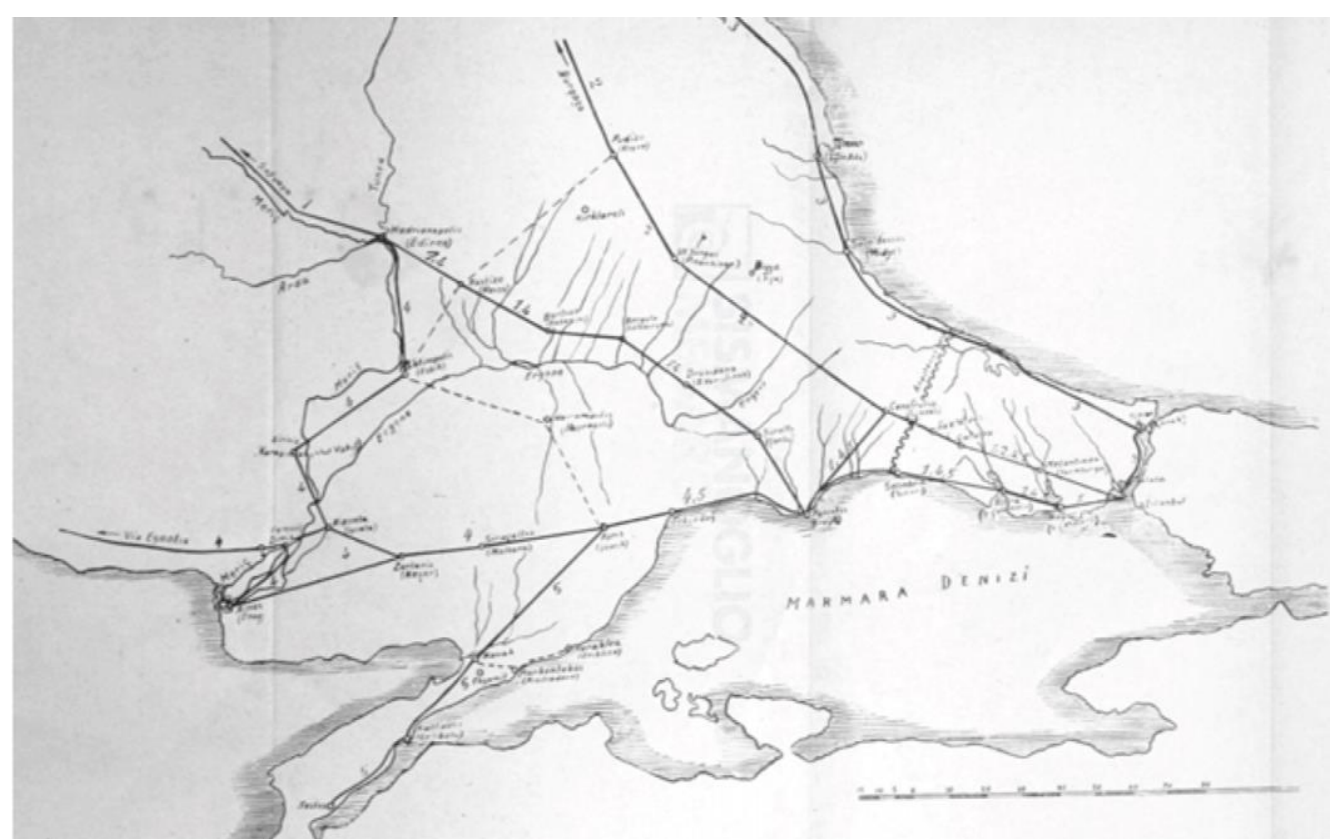

Figure 6. East Thrace Road Map

Source: Mansel, 1938.

The Via Militaris facilitated the movement both of soldiers, the original intention when Cicero called it a via militaris, and of ideas - an accidental by product of Roman road engineering (Figure 5). There is also a way of connecting

10. Ibid, 24. 
the city of Mansel (Figure 6) Feres with Enez. Geomorphological formations have changed the path used for centuries. It is thought that there are a few ways (secondary roads) to be traveled in a short time. A road through the secondary separated from the Via Egnatia reaches Gallipoli. ${ }^{11}$

\section{Historical Evaluation of the Via Egnatia as a Cultural Route}

The Emperors generalized the use of the roads throughout the entire Empire and linked their construction to the enterprises of conquest and occupation. The decision to build one of these roads was an immense civil engineering undertaking and the well-preserved remains of some can be found in numerous locations. As a general rule, a Roman road is composed of a foundation covered with gravel or cobblestones; the curved shape of the top layer and the side gutters drain the water from the road. These roads are also notable for their linearity. While some are the result of modernising previously existing ancient and even prehistoric roads, others are newly built roads. The Romans also continued to use secondary and more ancient roads.

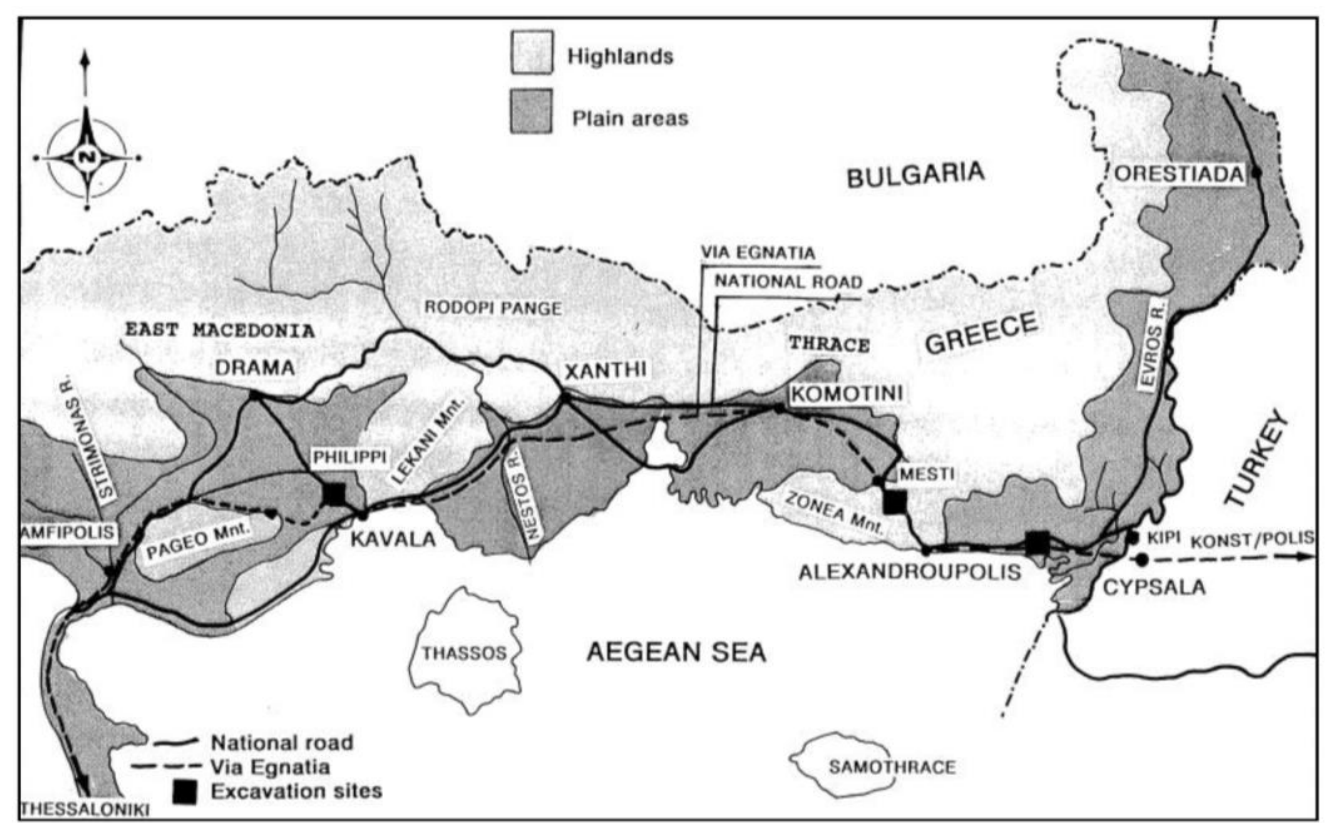

Figure 7. Via Egnatia in the Region of East Macedonia and Thrace, Greece, and the Sites of Trial Excavations

Source: G. S. Xeidakis and E. G. Varagouli, "Design and Construction of Roman Roads: The Case of Via Egnatia in the Aegean Thrace, Northern Greece," Environmental and Engineering Geoscience III, no. 1 (1997).

The implications of road construction for the economic, social and urban development of Roman territories are commonly described as cumulative: population centres popped up and grew along the roads, while farmers and

11. E. A. Zachariadu, Sol Kol Osmanlı Egemenliğinde Via Egnatia (Istanbul: Tarih Vakfı Yurt Yayınlar1, 1999). 
merchants became the principal users of the roads once all of the conquered regions were at peace. In this regard, historians indicate that the inhabitants of the Empire gradually took over the roads because they were directly useful to them. Another contributing factor to the takeover was the fact that the roads were not maintained by the imperial administration, but rather by the local authorities; proof of this can be found in the survival of Roman infrastructure for many centuries, some as late as the twentieth century. ${ }^{12}$

\section{Values of Via Egnatia}

\section{Archeological Value}

There are several archeological components on the road such as; Bradashesh Complex (Figures 8-9), Philippi Roman Forum (Figure 14), Edessa (Figures 1011), Traianoupolis, Octagon (Figure 12) and Bishop's Residence (Figures 13-14). Also there could be seen lots of milliaria (mile stone) which measure distances between main cities (Figures 15-16).
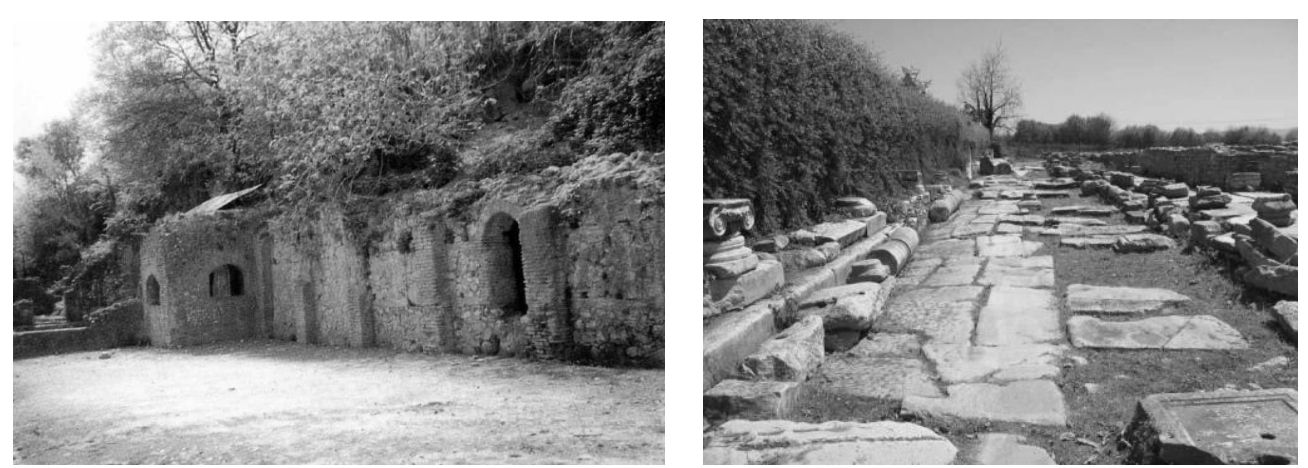

Figures 8-9. Bradashesh Complex and Philippi

Source: Fasolo, Via Egnatia, 146.

12. L. Cibin, "La Tecnica Stradale in Epoca Republicana ed Imperial," in Selciato Romano: il sampietrino (Roma: Gangemi Editore, 2003), 57-59; B. R. Hitchner, "Roads, Integration, Connectivity and Economic Performance in the Roman Empire," in Highways, Byways and Road Systems in the Pre-Modern World (ed.) Alcock, E. Susan, J. Bodel and R. J. A. Talbert. Malden: John Wiley \& Sons, 2012, 222-234; N. Rudd-Jones and D. Stewart, Roman Roads, in Pathways. Journeys along Britain's Historic Byways, from Pilgrimage Routes to Smugglers' Trails (London: Guardian Books, 2011), 41-54. 

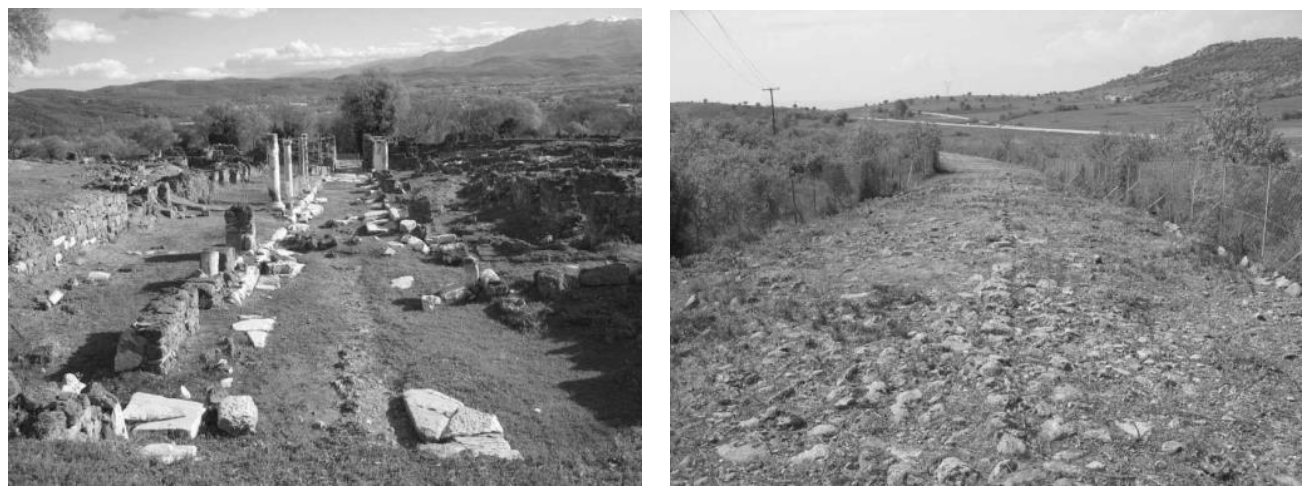

Figures 10-11. Edessa and Traianoupolis

Source: Fasolo, Via Egnatia, 146.
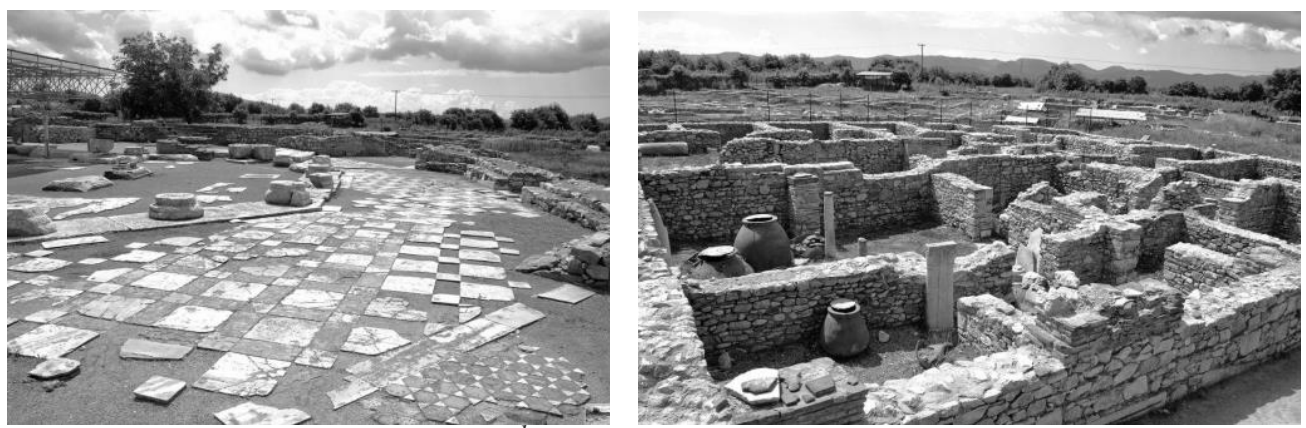

Figures 12-13. Octagon, AD. $4^{\text {th }}$ Century; Bishop's Residence Source: Url-9.

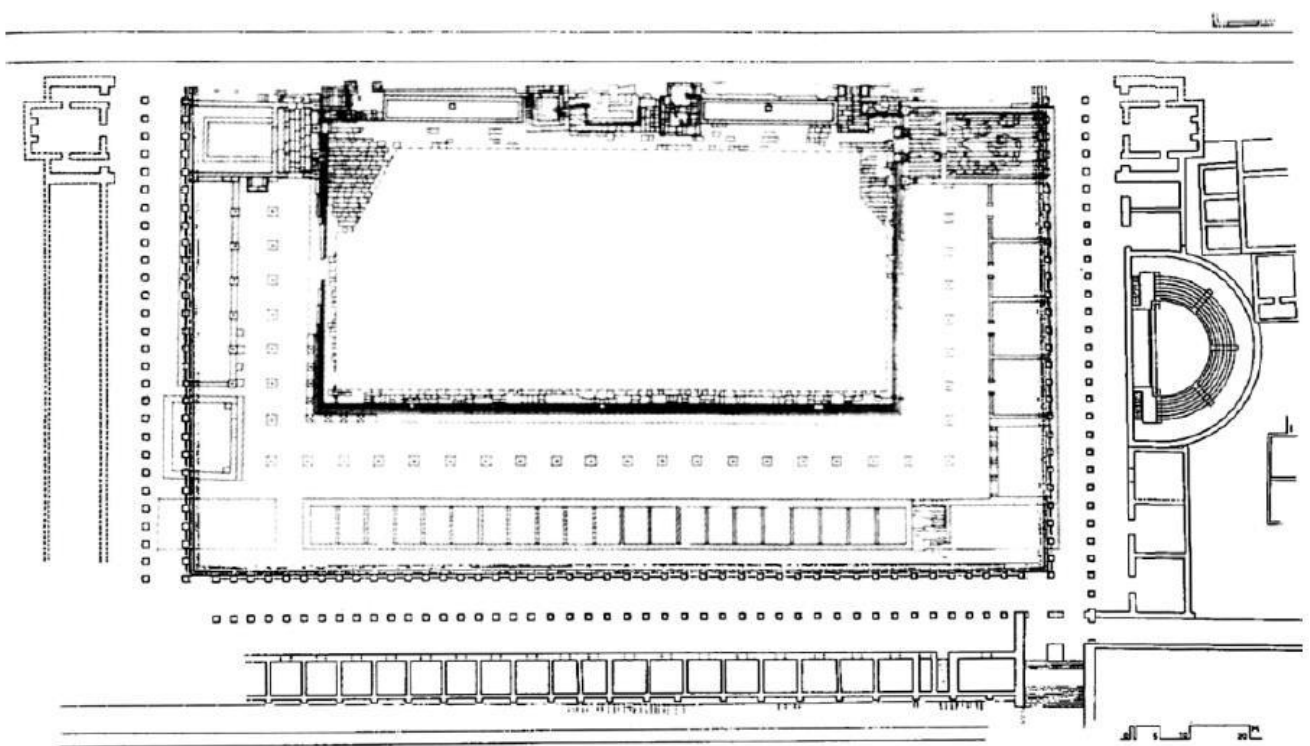

Figure 14. Philippi Roman Forum

Source: Lolos, Via Egnatia after Egnatius: Imperial Policy and Inter-regional Contacts, 2007. 

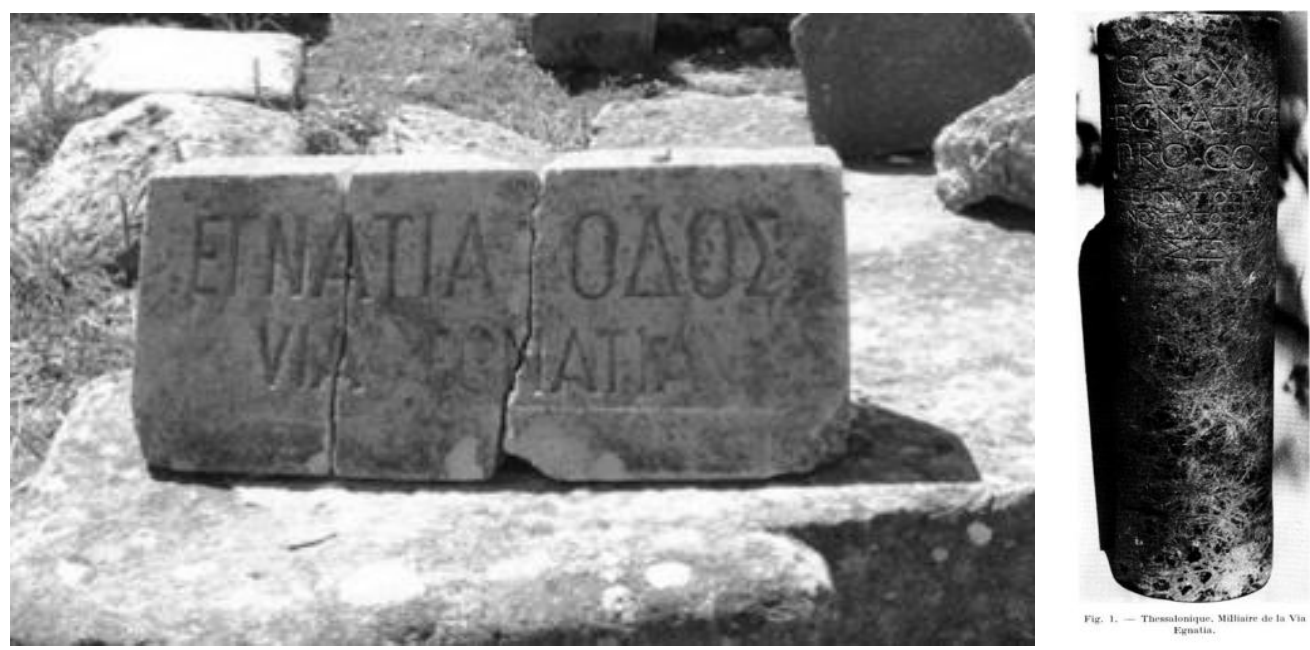

Figures 15-16. Archeological Remains; Mile Stone in Thessalonique Source: Url-4; Url-8.

All the roads o have sidewalks and milestones indicating the main distances (Figures 15-16).

\section{Historical Value}

The Via Egnatia is an important subsidiary route of the Roman Empire, it was for over 2300 years as a center of trade between East and West, also rich cultural exchange. Remains of ancient archaeological and cultural heritage of highly socially structured societies, linked with international trade routes as well as a landscape that could be considered as historical value.

Also, some parts of Via Egnatia were shown in the Peutinger Map. For instance, upriver, past an Ottoman bridge that could be the twin of the more famous one in Mostar, Bosnia, one reaches the Macedonian Republic's border at Qafë Thanë, a mountain pass just east of Lake Ohrid and the "Pons Servilii" listed on the The Peutinger Map (Url-2) (Figure 17).

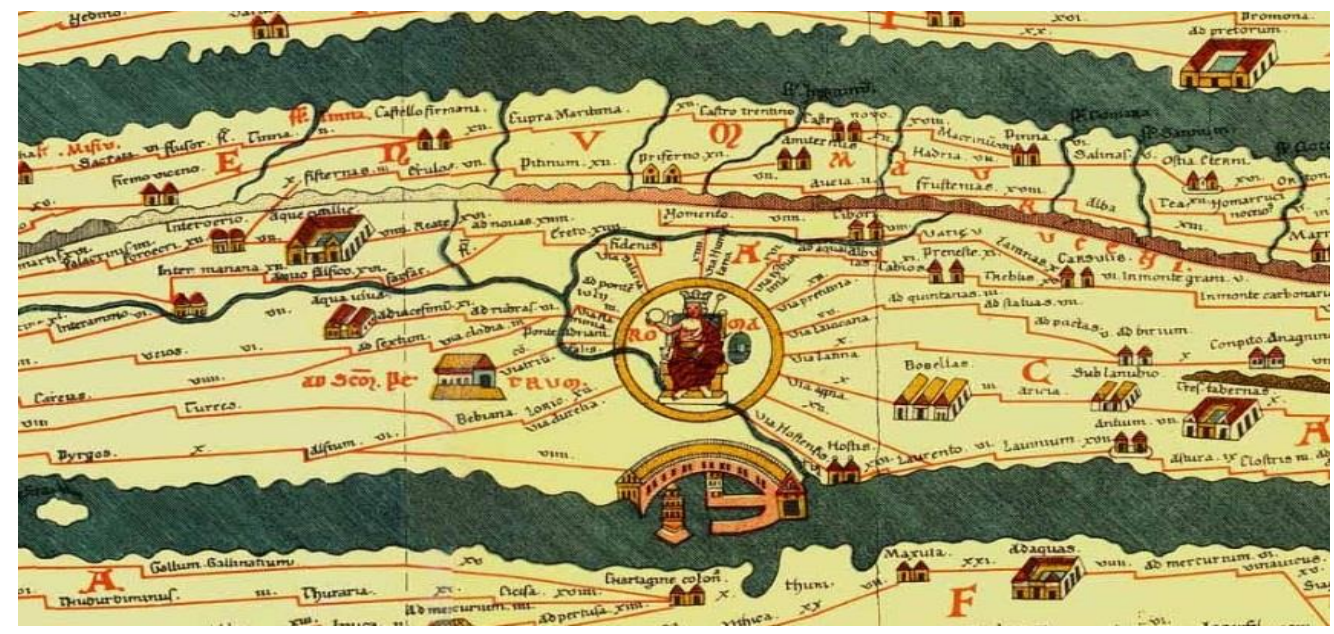

Figure 17. Peutinger Map

Source: Url-5. 


\section{Economic Value}

The cultural Route of Via Egnatia was conceived as a communication system at the service of an economic Project of Roman Empire from the 200 BC. In the Byzantine days, most of the land trade routes with Western Europe passed through Via Egnatia. Also, between the $1^{\text {st }}$ and $3^{\text {rd }}$ centuries, Durres was an important port and trading center on the Via Egnatia (Figure 18).

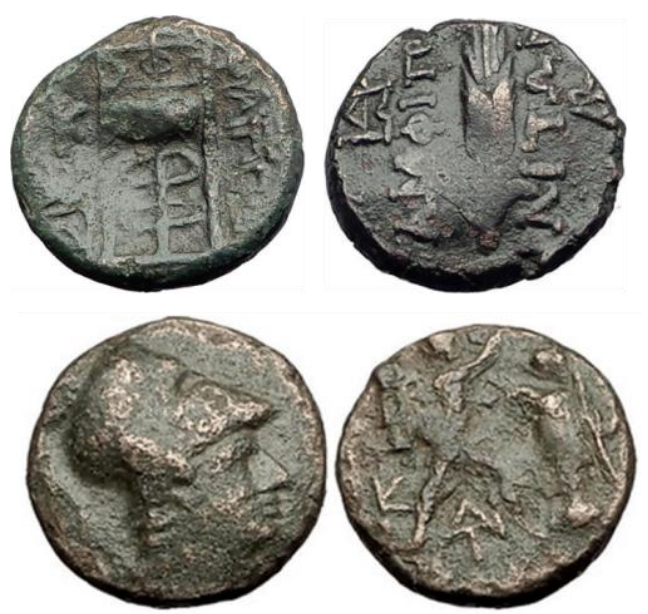

Figure 18. Ancient Greek Colony Coins A(ntoni) I(ussu) C(olonia) P(hilippensium)

Natural Value

Via Egnatia is a cultural route that is related to the communication and trade in some certain historical periods. Also, the route includes all the necessary elements, not only the cultural elements such as towns, villages, buildings, archaeological remains, ports, bridges and so on, but also the naturel elements such as mountains, lands, rivers, plants.

\section{Technical Value}

Technical value is related with the technical, technological, structural, material and craftsmanship of the period. It provides evidence as to the revolution in road construction brought about by the Romans (Figure 21). Furthermore, Via Egnatia plays an unique role in the framework of the Roman road network in that it induced the development of sites, ideas, works, testimonies and memories which in the course of over 2300 years of history. 

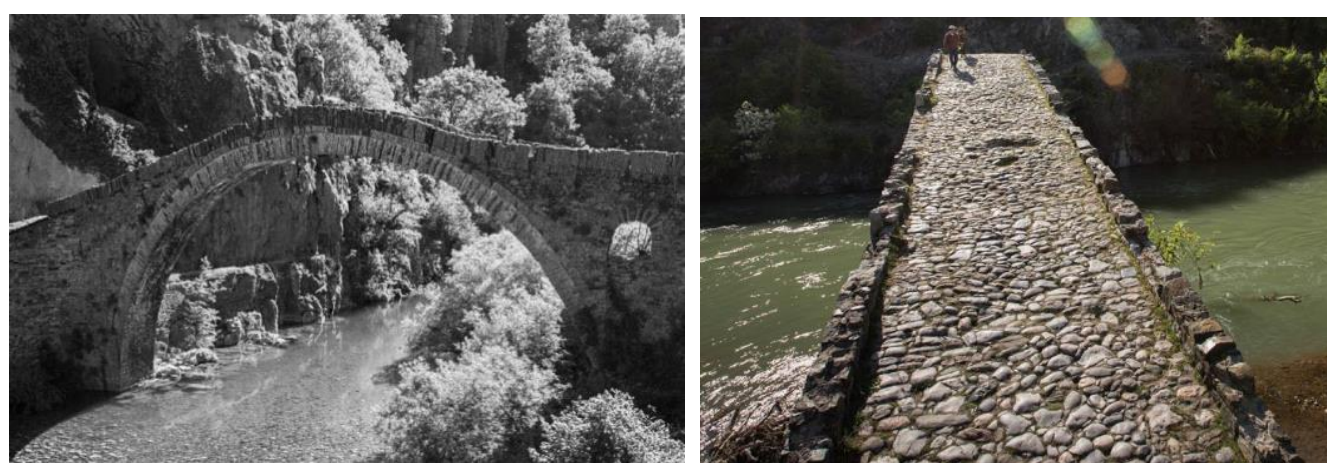

Figures 19-20. Ottoman Arched Bridge over Voidomatis River, Vikos Gorge (Danita Delimont, 2019); Another Bridge on the Via Egnatia Source: Url-6; Url-2.

Outstanding feats of engineering, bridges, viaducts, galleries, ensured an unwaveringly straight course, across expanses of water and mountains (Figures 19-20).
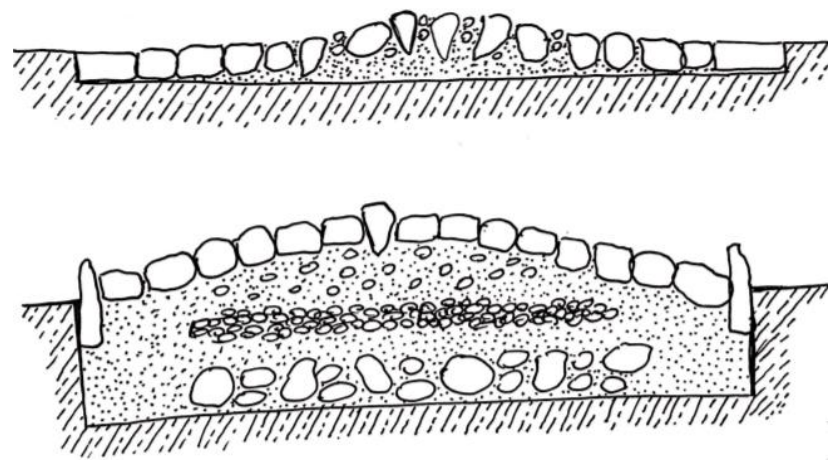

Figure 21. Section of the Roman Road Source: Akcabozan, 2019.

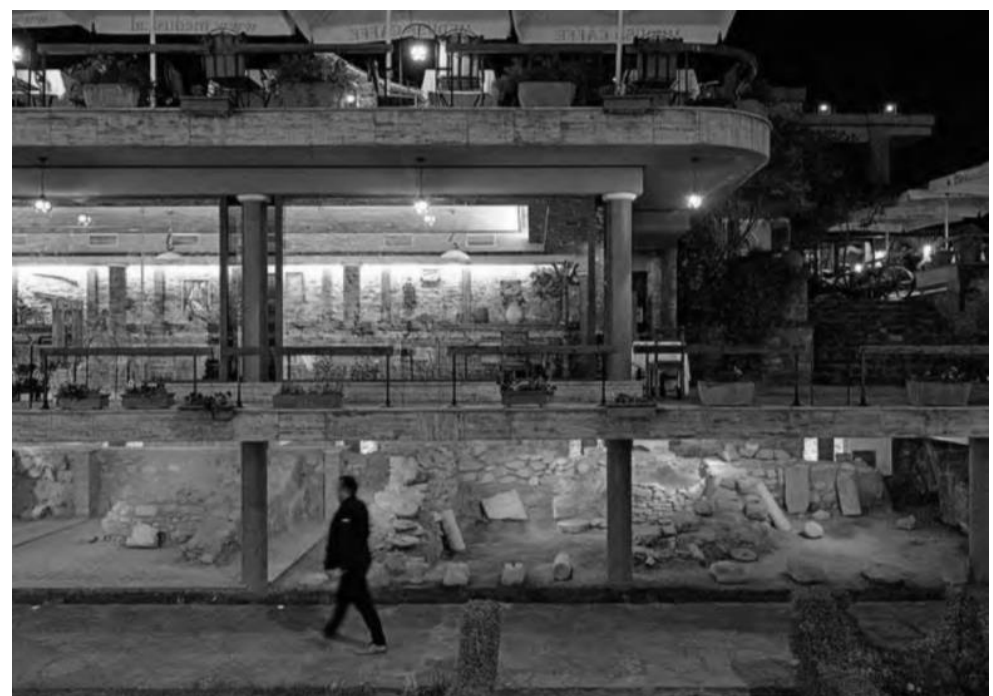

Figure 22. Modern Construction in Elbasan Goes on Above Archeology Source: Url-7. 


\section{Multi-Layer Value}

Multi-layer value defines the relations of cultural assets in multilayered and multicultural settlements which the products of other periods and covers the aims of a holistic conservation within these relations. These values define the quality of cultural heritage. Via Egnatia presents multi-layer value of historical and cultural perspective. Traces of the road are still being read today's modern cities (Figure 22).

\section{Cultural Value}

Many different ethnic groups used the Via Egnatia, and met each other along its trails, in its caravanserais: Greeks and Jews, Vlachs and Pomaks, Turks, Venetians, Egyptians and Roma. Also modern migrants travelled along it, for example the Evros-Greeks who left their country in the sixties and many of them came back in the last decade. In addition, the Via Egnatia, with intervals due to political or geografical trouble, has been a real trans-Balkan highway (Url-9). Therefore it could be said that the road is both guideline and symbol of cultural interaction.

\section{Document Value}

It is defined as the universal conservation discourse " ... a set of important values that reflect the social, cultural and economic life thus reflects the next generation of more accurate and direct information on the subject". In addition to this, UNESCO and ICOMOS agreed that dynamism in the forms of movement, idea of exchange and interchange between regions, continuity in space and time as well as integrity and multifaceted structure are the fundamental features shaping the concept of cultural routes.

Via Egnatia has a document value by exceeding the total value of the components making it up and through which it achieves its cultural importance as well as underlines exchange and dialogue between countries and regions.

Documents that give a picture of the period they belong to, also give us information about the natural and physical environment in different periods. As an example photo provided by Albania's National Coastline Agency shows a sketch drawn from Edward Lear in 1848, the English artist known mainly for "The owl and the pussy-cat" and who traveled along Via Egnatia (Figures 23-24). ${ }^{13}$

13. National Coastline Agency via AP. Albania Promotes Via Egnatia with Edward Lear's Sketches (The Associated Press - By Llazar Semini - Associated Press, 2017). 

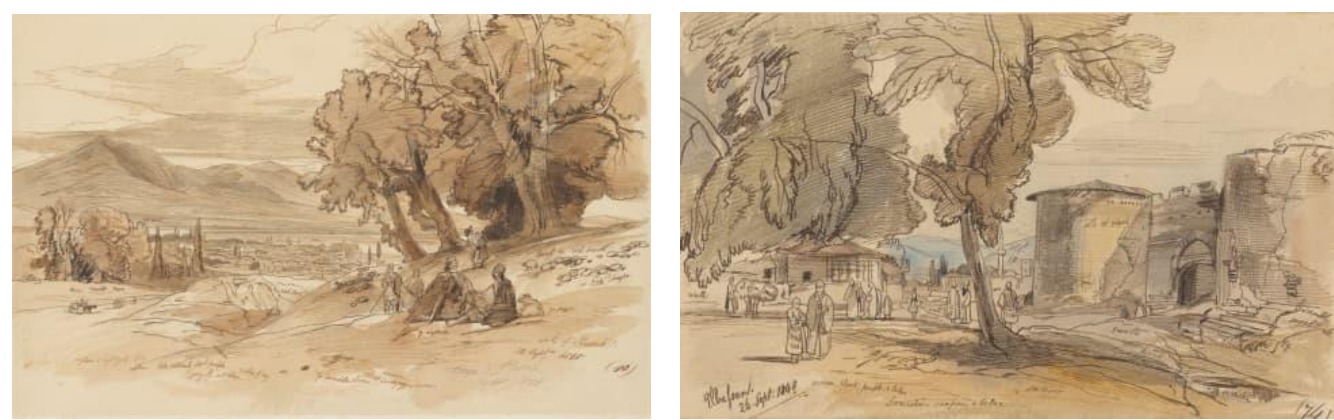

Figures 23-24. Lear's Sketches Made in 1848 during his First Trip to Albania Source: National Coastline Agency, 2017.

\section{Traces of Via Egnatia in Turkey}

In general, the Thrace region, we know from the sources that it starts from Macedonia in the West and covers the area up to (Bosphorus) Thrakios in the East. Remains of the Via Egnatia road surface itself are rare and few milliaria (mile stone) have been recovered in Thrace region. By far the most important is the lack of verified archeological evidence of the remains of the Via Egnatia in Turkey. Archeological paths of the original roads are very limited in Turkey. Only a few sections of the road's surface have been subjected to archeological excavations.

The Via Egnatia was originally built only to Ipsala, on the Turkish side of the Evros River. Because the road was informally connected with other, older roads that were later upgraded by the Romans, we only know without precise dating that it was later extended to Byzantium through the dense network of new roads, some going straight along the Sea of Marmara's coast, past Tekirdağ and Silivri, others running north through the city of Hadrianopolis (Edirne), to connect with the Belgrade road, or Orta Kol. In most cases, only the names are known of the stations between Ipsala and Istanbul. At the town of Marmara Ereğlisi, just 97 kilometers from Istanbul, inscriptions on four milestones all begin with the same simple salutation: "Good Luck," as if to subtly warn travelers from the west to be wary of the big city's temptations and hazards, of which there were as many then as today (Url-7).

The Via Egnatia was the Roman Empire's main route in use long after the Empire fell. It gained new life under the Ottomans, even before their 1453 conquest of Constantinople, who reversed traffic and made it one of their primary corridors west, especially during the Balkan conquests of the late 14th century. As a result, today many mosques, markets, charitable kitchens (imarets), caravansarais (hans) and baths (hammams) along the route date from this time, when in Turkish it was known as Rumeli Sol Kol, literally "Balkan Left Arm."14

14. C. Heywood, Sol Kol: Osmanl Dönemi’nde Via Egnatia: 17. Yüzyll Sonu ve 18. Yy Başııda Sol Koldaki Menzilhaneler (Tarih Vakfı Yurt Yayınları, 1999), 140. 

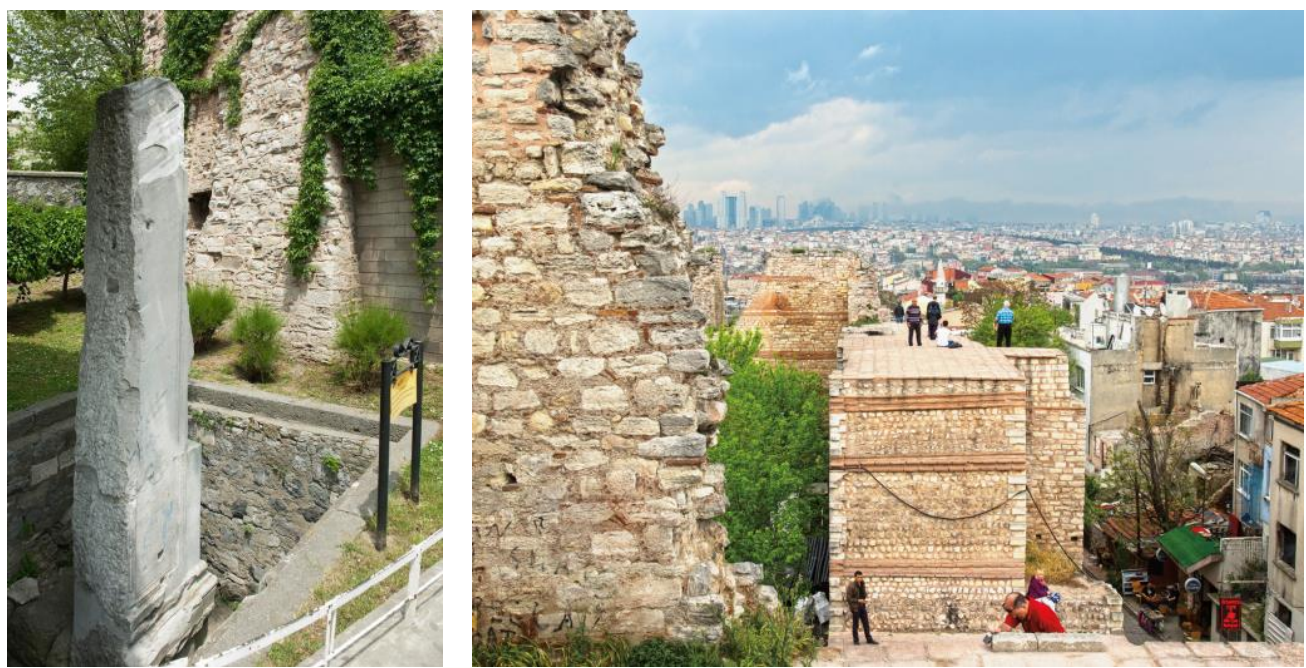

Figures 25-26. The Mile Stone in Sultanahmet: Million; the End Point of the Via Egnatia in Istanbul: Golden Gate, Istanbul

Source: Url-7.

The road could be said to end definitively at Istanbul's Million (Figure 25), in the Sultanahmet Square, near the Hagia Sofia. This served as the marker from which all Byzantium's road distances were measured.

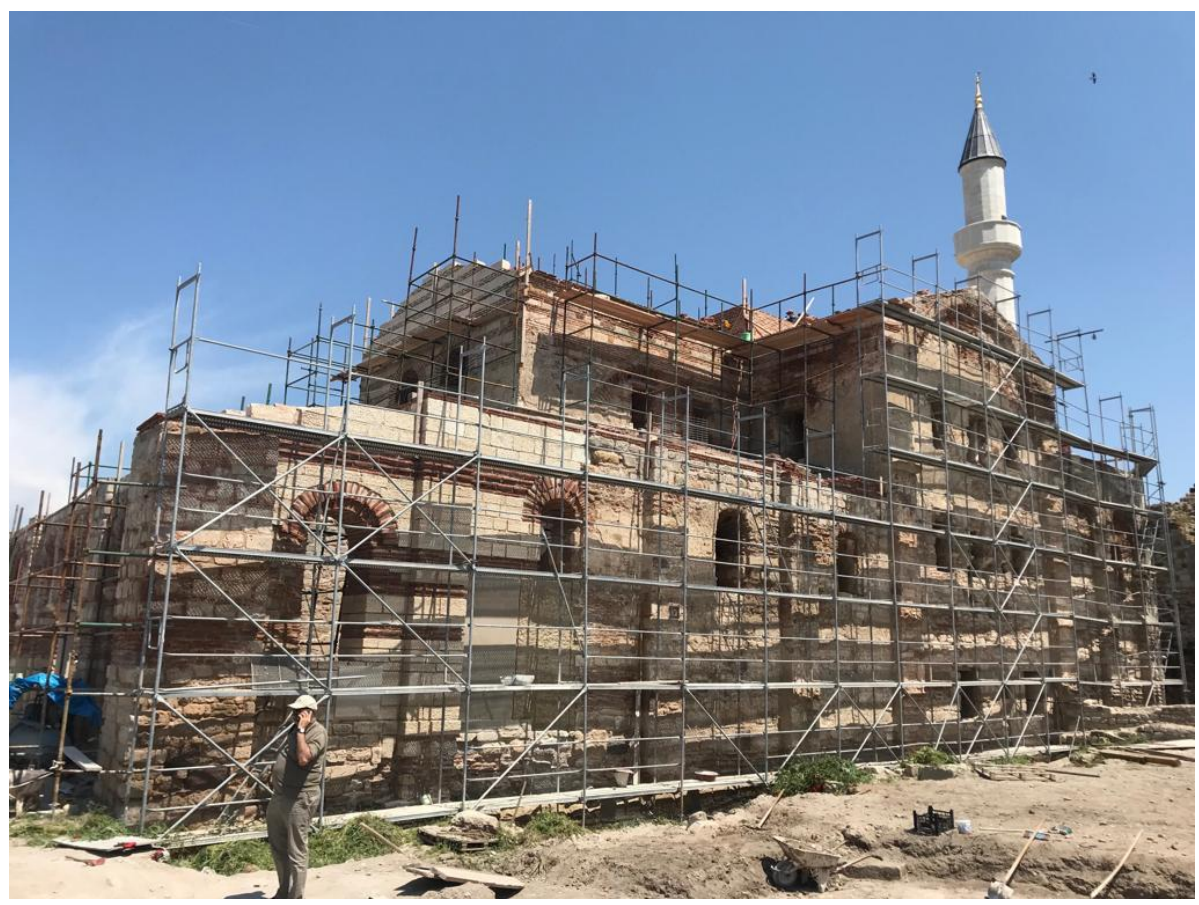

Figure 26. Ainos Hagia Sophia Church (Fatih Mosque)

Source: Binan, 2019. 

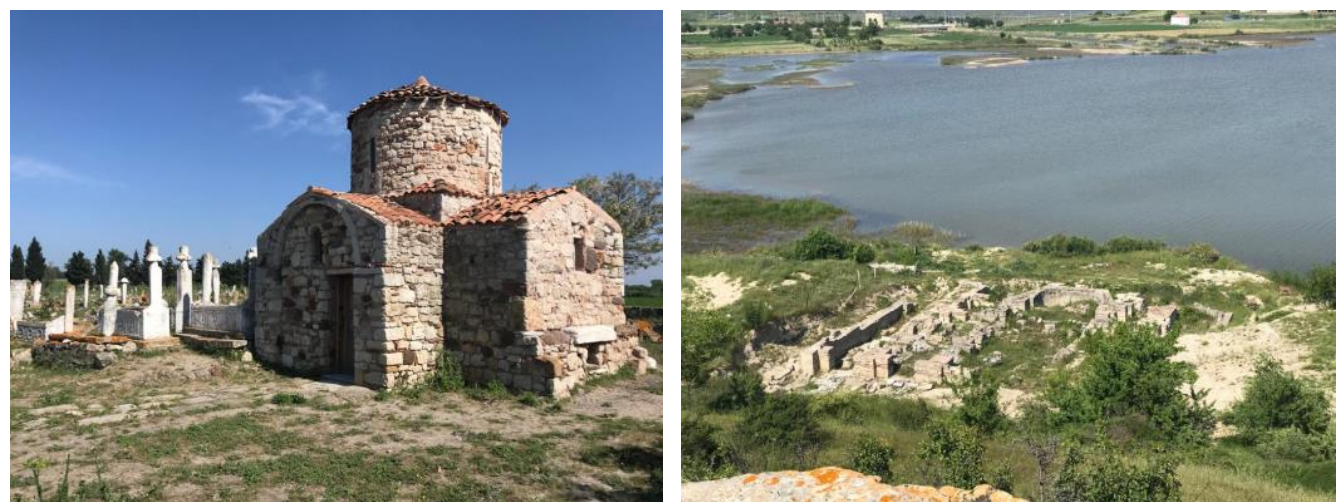

Figures 27-28. Archaeological Remains in Enez; Shapel and King's Daughter

Basilica

Source: Binan, 2019.

Other traces of Via Egnatia could be seen in the South East of Enez, West of today's Taşaltı lake, one of the two harbours of Enez, in an area called King's Daughter (Figures 27-28). The basilica which is $30 \mathrm{~m}$. long has three aisles and in between these there lies a Pastophorion each. Recent excavations revealed that the basilica went through 7 building phases, the earliest of which dates back to the Roman period (Url-1) (Figure 26).

\section{Methodology}

The comparative analysis was used by specifying how the Transnational Serial Nominations in lineer system (Table 1). In each country, carefully guided selection processes were carried out until reaching a definitive identification of the section, subsections and segments that were going to be nominated.

Thereafter, the comparative analysis was made in between roman roads (Table 2) which are potential for the Transnational Serial Nominations as lineer systems. Outstanding Universal Value scenario and criteria were discussed for the Via Egnatia. In addition to all these, value- critera evaluation (Table 3) is made for the cultural road as a potential lineer system Transnational Serial Heritage.

Via Egnatia as a Transnational Serial Heritage Potential for UNESCO World Heritage List

Outstanding Universal Value Scenario

It is the first and most important of the great roads built by the Ancient Romans and is, therefore, also known as "Egnatia Odos". Via Egnatia is a Road System developed on a broad geographical area, conceived, designed and carried out with Ancient mean, in the most Roman geography in the world and is still in use, fulfilling functions of physical and symbolic connectivity between east and west. These countries today continue to exchange values, products and knowledge through routes physically traced more than $1100 \mathrm{~km}$ in length (696 miles/746 Roman miles), which allow the continuing of a continental connectivity until the 
present day.

Functional Continuity of the Road

The Via Egnatia, even during the age of Byzantium and the Ottomans, continued to function, partially: to be used by merchants, armies, wayfarers, preachers, crusaders, invaders, explorers, migrants and fugitives, in both directions. In the middle of the $17^{\text {th }}$ century, military movements were carried out in the Ottoman period. Also, the Via Egnatia was the main road in the commercial relations with the Balkan hinterland, which was the target of the activities in the sea, both in the Aegean and the Adriatic maritime world, and in the inside of the continent.

Another important function was the preservation of the quality of the Roman and Byzantine periods; which is being "the most important element of the communication network of the empire". Like the Roman paraveredus before this, the Ottoman menzilhane and ulak system and the system of dispassion, in an era before electronic telecommunication and telegraphy, provided the public with clear or confidential instructions to the public's knowledge to be transmitted from the center to the provincial authorities, which was carrying the wishes and demand. ${ }^{15}$ The Via Egnatia was in use for almost 2000 years with some parts still in use as secondary roads today.

Outstanding Universal Value Critaria Proposal

\section{Criteria (i)}

- It is the first and most important of the great roads built by the Ancient Romans and is, therefore, also known as "Egnatia Odos".

\section{Criteria (ii)}

- It achieves the cultural importance as well as underlines exchange and dialogue between countries and regions. The road is both guideline and symbol of cultural interaction.

\section{Criteria (iii)}

- It gives great evidence to the roman road system and architectural heritage on the road.

\section{Criteria (iv)}

- It provides evidence as to the revolution in road construction brought about by the Romans.

- In the XVII century, it became once again the main route of Ottoman Empire access to the West and essential for the political and military activities.

- The Via Egnatia is important in the history of architectural restoration for the many works aimed at reclaiming and restoring it, undertaken as of the XVI century.

Criteria (vi) The Via Egnatia plays an unique role in the framework of the Roman road network in that it induced the development of sites, ideas, works, testimonies

15. Ibid. 
and memories which, in the course of over 2300 years of history, formed a complex cultural environment, universally recognized as such by European writers, painters, poets and travelers who were undeniably marked by Via Egnatia and the adjacent territory areas.

\section{Comparative Analysis}

Table 1. Examples of Linear System Transnational Serial Nominations in the Tentative List ${ }^{16}$

\begin{tabular}{|c|c|c|c|c|c|c|}
\hline & \multicolumn{6}{|c|}{ TRANSBOUNDARY SERIAL NOMINATIONS_LINEER SYSTEM_TL } \\
\hline Property & $\begin{array}{c}\text { Augustow } \\
\text { Canal, } \\
\text { BELARUS }\end{array}$ & $\begin{array}{c}\text { Frontiers of } \\
\text { the Roman } \\
\text { Empire } \\
\text { Croatian } \\
\text { Limes. }\end{array}$ & $\begin{array}{c}\text { Frontiers of } \\
\text { the } \\
\text { Roman } \\
\text { Empire } \\
\text { Ripa } \\
\text { Pannonica in } \\
\text { HUNGARY. }\end{array}$ & $\begin{array}{l}\text { The } \\
\text { Cerdagne } \\
\text { railway, } \\
\text { FRANCE }\end{array}$ & $\begin{array}{l}\text { Via Appia } \\
\text { "Regina } \\
\text { Viarum" } \\
\text { ITALY }\end{array}$ & $\begin{array}{c}\text { The Roman } \\
\text { antique } \\
\text { monuments on } \\
\text { the Middle } \\
\text { Danube, } \\
\text { SLOVAKIA }\end{array}$ \\
\hline Criterion & (i)(ii) & (i)(ii)(iii)(iv)(v) & (ii)(iii)(iv) & (iv) & (i)(iii)(iv)(v)(vi) & (ii)(iii)(iv)(v) \\
\hline Length & $101 \mathrm{~km}$. & $188 \mathrm{~km}$. & $415 \mathrm{~km}$. & $62,5 \mathrm{~km}$. & Under $540 \mathrm{~km}$. & Not specified. \\
\hline Period & $\begin{array}{c}\text { Early } \\
\text { nineteenth } \\
\text { century. }\end{array}$ & Not specified. & Not specified. & $\begin{array}{c}\text { Built } \\
\text { between } \\
1903 \text { et } \\
1911 . \\
\end{array}$ & $\begin{array}{c}\text { Over } 2,300 \text { years } \\
\text { of history. }\end{array}$ & $\begin{array}{l}\text { First to fourth } \\
\text { Centuries. }\end{array}$ \\
\hline Uses & $\begin{array}{l}\text { Used for } \\
\text { exporting } \\
\text { grain and } \\
\text { presumably } \\
\text { timber to } \\
\text { Baltic ports. }\end{array}$ & $\begin{array}{l}\text { The Danube } \\
\text { acted as } \\
\text { the border } \\
\text { between } \\
\text { the Roman } \\
\text { Empire } \\
\text { and barbaric } \\
\text { lands. }\end{array}$ & $\begin{array}{l}\text { A river } \\
\text { frontier. }\end{array}$ & $\begin{array}{l}\text { A narrow- } \\
\text { track and } \\
\text { electric } \\
\text { traction } \\
\text { railway line } \\
\text { used to link } \\
\text { up the high } \\
\text { cantons of } \\
\text { the Pyrenees. }\end{array}$ & $\begin{array}{l}\text { It was the first } \\
\text { and most } \\
\text { important of } \\
\text { great roads built } \\
\text { by the Romans. }\end{array}$ & $\begin{array}{l}\text { An extensive } \\
\text { fortification } \\
\text { system. }\end{array}$ \\
\hline $\begin{array}{l}\text { Current } \\
\text { use }\end{array}$ & $\begin{array}{c}\text { The gates and } \\
\text { chambers } \\
\text { need } \\
\text { repairing. }\end{array}$ & $\begin{array}{l}\text { Archaeological } \\
\text { remains. }\end{array}$ & $\begin{array}{l}\text { Archaeological } \\
\text { remains. }\end{array}$ & $\begin{array}{l}\text { Used for } \\
\text { tourist } \\
\text { purposes. }\end{array}$ & $\begin{array}{l}\text { Archaeological } \\
\text { remains. }\end{array}$ & $\begin{array}{l}\text { An open-air } \\
\text { museum. }\end{array}$ \\
\hline Technology & $\begin{array}{c}\text { Economically } \\
\text { it did not } \\
\text { meet } \\
\text { expectations. }\end{array}$ & & $\begin{array}{l}\text { Unified the } \\
\text { principles of } \\
\text { planning } \\
\text { military sites. }\end{array}$ & $\begin{array}{l}\text { Nineteen } \\
\text { tunnels }\end{array}$ & $\begin{array}{l}\text { Important in the } \\
\text { history of } \\
\text { architectural } \\
\text { restoration. }\end{array}$ & \\
\hline $\begin{array}{l}\text { Key } \\
\text { features }\end{array}$ & $\begin{array}{l}\text { A unique } \\
\text { hydraulic } \\
\text { engineering } \\
\text { work. }\end{array}$ & $\begin{array}{l}\text { These were } \\
\text { connected by } \\
\text { military roads } \\
\text { and Danube. }\end{array}$ & $\begin{array}{l}\text { One of the } \\
\text { most } \\
\text { significant } \\
\text { river frontiers. }\end{array}$ & $\begin{array}{c}650 \\
\text { engineering } \\
\text { masterpieces, } \\
\text { including } \\
\text { nineteen } \\
\text { tunnels and } \\
\text { two } \\
\text { remarkable } \\
\text { bridges, the } \\
\text { Séjourné } \\
\text { Viaduct and } \\
\text { the Pont } \\
\text { Gisclard. } \\
\end{array}$ & $\begin{array}{l}\text { One of the } \\
\text { earliest and } \\
\text { strategically most } \\
\text { important Roman } \\
\text { roads of the } \\
\text { ancient republic. }\end{array}$ & $\begin{array}{l}\text { The Romans } \\
\text { did not succeed } \\
\text { in keeping the } \\
\text { borders of } \\
\text { Panonia. }\end{array}$ \\
\hline
\end{tabular}

16. Qhapaq Nan, Andean Road System, Nomination File, 1120. 
Table 2. Via Appia - Via Egnatia and Via Militaris Comparison

\begin{tabular}{|c|c|c|c|}
\hline Property & $\begin{array}{l}\text { Via Appia "Regina } \\
\text { Viarum" - ITALY }\end{array}$ & $\begin{array}{l}\text { Via Egnatia "Egnatia } \\
\text { Odos" - }\end{array}$ & Via Militaris \\
\hline Criterion & (i)(iii)(iv)(v)(vi) & (i)(ii)(iii)(iv)(vi) & (i)(iii)(iv)(v)(vi) \\
\hline Length & Under $540 \mathrm{~km}$. & $1120 \mathrm{~km}$ & $1054 \mathrm{~km}$ \\
\hline Period & $\begin{array}{l}\text { Over } 2,300 \text { years } \\
\text { of history. }\end{array}$ & Over 2,000 years & Over 2,000 years \\
\hline Uses & $\begin{array}{l}\text { It was the first and most } \\
\text { important of great roads } \\
\text { built by the Romans. }\end{array}$ & $\begin{array}{l}\text { the Via Egnatia links not } \\
\text { only Western and Eastern } \\
\text { empires, but also more } \\
\text { than two millennia of } \\
\text { history over } 1120 \\
\text { kilometers. }\end{array}$ & $\begin{array}{l}\text { The road thus facilitated } \\
\text { the movement both of } \\
\text { soldiers, the original } \\
\text { intention when Cicero } \\
\text { called it a via } \\
\text { militaris, and of ideas-- } \\
\text { an accidental by product } \\
\text { of Roman road } \\
\text { engineering. }\end{array}$ \\
\hline Current use & Archaeological remains. & $\begin{array}{l}\text { Archaeological remains } \\
\text { and new motor way. }\end{array}$ & Archaeological remains. \\
\hline Technology & $\begin{array}{l}\text { Important in the history of } \\
\text { architectural restoration. }\end{array}$ & $\begin{array}{l}\text { It provides evidence as to } \\
\text { the revolution in road } \\
\text { construction brought } \\
\text { about by the Romans. }\end{array}$ & $\begin{array}{l}\text { Important in the history } \\
\text { of military roads. }\end{array}$ \\
\hline Key features & $\begin{array}{l}\text { The Via Appia is one of } \\
\text { the earliest and } \\
\text { strategically most } \\
\text { important Roman roads of } \\
\text { the ancient republic. }\end{array}$ & $\begin{array}{l}\text { First, the sources refer to } \\
\text { "the road goes to } \\
\text { Candavia (Candavia: } \\
\text { Macedonia Region, } \\
\text { Illarian Mountains) } \\
\text {-High technical } \\
\text { achievement } \\
\text { - The official trade of the } \\
\text { Roman Empire } \\
\text { - Contribution to the } \\
\text { growth of certain cities } \\
\text { - Roman network over } \\
\text { the cities } \\
\text { - Cultural traces }\end{array}$ & $\begin{array}{l}\text { The Via Militaris is } \\
\text { indicated by the name of } \\
\text { the longest Roman road } \\
\text { that crosses the Balkan } \\
\text { Peninsula diagonally. } \\
\text { It was built mainly to } \\
\text { support military actions, } \\
\text { as transportation } \\
\text { between towns and } \\
\text { army camps was an } \\
\text { essential requirement } \\
\text { for the conduct of } \\
\text { military campaigns. }\end{array}$ \\
\hline
\end{tabular}

Table 3. Via Egnatia as a Potential Transnational Serial Heritage; Value Criteria Evaluation

\begin{tabular}{|l|c|l|l|l|l|l|l|l|}
\hline & $\begin{array}{l}\text { Archeological } \\
\text { Value }\end{array}$ & $\begin{array}{l}\text { Historical } \\
\text { Value }\end{array}$ & $\begin{array}{l}\text { Natural } \\
\text { Value }\end{array}$ & $\begin{array}{l}\text { Technical } \\
\text { Value }\end{array}$ & $\begin{array}{l}\text { Economic } \\
\text { Value }\end{array}$ & $\begin{array}{l}\text { Cultural } \\
\text { Value }\end{array}$ & $\begin{array}{l}\text { Multi- } \\
\text { Layer } \\
\text { Value }\end{array}$ & $\begin{array}{l}\text { Document } \\
\text { Value }\end{array}$ \\
\hline $\begin{array}{l}\text { Criteria } \\
\text { (i) }\end{array}$ & $\checkmark$ & & & & & $\checkmark$ & & \\
\hline $\begin{array}{l}\text { Criteria } \\
\text { (ii) }\end{array}$ & & & & $\checkmark$ & $\checkmark$ & $\checkmark$ & & \\
\hline $\begin{array}{l}\text { Criteria } \\
\text { (iii) }\end{array}$ & $\checkmark$ & $\checkmark$ & & & & $\checkmark$ & $\checkmark$ & $\checkmark$ \\
\hline $\begin{array}{l}\text { Criteria } \\
\text { (iv) }\end{array}$ & $\checkmark$ & & & $\checkmark$ & & & & \\
\hline $\begin{array}{l}\text { Criteria } \\
\text { (v) }\end{array}$ & & & & & $\checkmark$ & & & \\
\hline $\begin{array}{l}\text { Criteria } \\
\text { (vi) }\end{array}$ & & & & & $\checkmark$ & $\checkmark$ & & $\checkmark$ \\
\hline $\begin{array}{l}\text { Criteria } \\
\text { (vii) }\end{array}$ & & & $\checkmark$ & & & & & \\
\hline
\end{tabular}

17. S. Strabo, The Geography of Strabo (trans.) H. L. Jones. 1924.

18. J. Berechman, "Transportation - Economic Aspects of Roman Highway Development: The Case of Via Appia," Transportation Research Part A: Policy and Practice 37, no. 5 (2003): 453-478. 


\section{Discussion and Conclusions}

The new World Heritage System, Transnational Serial Nominations, which has emerged solution depending on excessive number of nominations on the list, has caused many cultural routes and cultural assets are evaluated as a whole Serial Nominations, which all components have joint outstanding universal value. Therefore, all state parties in today's world, has been collaborating for the Transnational Serial Nomination process of traces of a cultural domain.

The need for a closer collaboration between countries, and the necessity of promoting a common language and integrated conservation approach in order to encourage meaningful dialogue could be suggested for the Transnational Serial Nomination process.

It is important to point out the need for the integrated preservation of the road system in different countries, in which Via Egnatia passed by, not only for its historic value, but also for other values and its significance to modern road technology.

This publication considers the specific situation where there could be transboundary co-operation involving protected areas, and where both conservation and peaceful co-operation are important objectives. It is important to consider all these components and the values, which are relatively difficult to preserve being just contributing as one part of the whole architectural heritage.

\section{Bibliography}

Berechman, J. "Transportation - Economic Aspects of Roman Highway Development: The Case of Via Appia." Transportation Research Part A: Policy and Practice 37, no. 5 (2003): 453-478.

Cibin, L. "La Tecnica Stradale in Epoca Republicana ed Imperial." [Road Technology in Republican and Imperial Times.] In Selciato Romano: il sampietrino. Roma: Gangemi Editore, 2003, 57-59.

Deluka, A., V. Dragcevic and T. Rukavina. "Roman roads in Croatia." In Proceedings of the First International Congress on Construction History. Edited by S. Huerta. Madrid: Instituto Juan de Herrera, 2003.

Dzino, D. Illyricum in Roman Politics, 229 BC-AD 68. Cambridge University Press, 2010.

Gaba, E. and Sting. Via Egnatia Foundation, Via Egnatia, 2006. Retrieved from: http://www.viaegnatiafoundation.eu/. [Accessed 9 January 2019].

Geoffrey, N. and L. Hammond. Subject: Ancient Geography, 2016. Retrieved from: https://www.oxfordre.com.

Great Britain Naval Intelligence Division, Handbook of Turkey in Europe.

Heywood, C. Sol Kol: Osmanl Dönemi'nde Via Egnatia: 17. Yüzyll Sonu ve 18. Yy Başında Sol Koldaki Menzilhaneler [Left Arm: Via Egnatia in the Ottoman Period: End of the $17^{\text {th }}$ Century and the Headquarters on the Left Arm at the Beginning of the $18^{\text {th }}$ Century.] Tarih Vakfi Yurt Yayınları, 1999.

Hitchner, B. R. "Roads, Integration, Connectivity and Economic Performance in the Roman Empire." In Highways, Byways and Road Systems in the Pre-Modern World. Edited by Alcock, E. Susan, J. Bodel and R. J. A. Talbert. Malden: John Wiley \& Sons, 2012, 222-234. 
Holdich, T. Boundaries in Europe and the Near East. London: Macmillan and Co., 1918. International Charter on Cultural Routes, Quebec, 2008.

IUCN. Guidelines for Protected Area Management Categories. Gland, Switzerland and Cambridge, UK: CNPPA with the assistance of WCMC. IUCN, 1994.

Lolos, Y. "Via Egnatia after Egnatius: Imperial Policy and Inter-regional Contacts." Mediterranean Historical Review 22, no. 2 (2007): 273-293.

Mansel, A. M. The Culture and History of Thrace. Istanbul: Resimli Ay Matbaas1, 1938.

National Coastline Agency via AP. Albania Promotes Via Egnatia with Edward Lear's Sketches. The Associated Press - By Llazar Semini - Associated Press, 2017.

Rudd-Jones, N. and D. Stewart. Roman Roads, in Pathways. Journeys along Britain's Historic Byways, from Pilgrimage Routes to Smugglers' Trails, London: Guardian Books, 2011, 41-54.

Strabo, S. The Geography of Strabo. Translated by H. L. Jones. 1924.

Talbert, R. J. A. (Ed.). Barrington Atlas of the Greek and Roman World. Princeton, N.J.: Princeton University Press, 2000.

UNESCO. Guidelines for the Preparation of Serial Nominations to the World Heritage List. UNESCO World Heritage Center, 2001. Retrieved from: http://whc.unesco.org/ archive/serial-noms.htm. [Accessed 9 January 2019].

Xeidakis, G. S. and E. G. Varagouli. "Design and Construction of Roman Roads: The Case of Via Egnatia in the Aegean Thrace, Northern Greece." Environmental and Engineering Geoscience III, no. 1 (1997): 123-132.

Zachariadu, E. A. Sol Kol Osmanl Egemenliginde Via Egnatia. [Left Arm Via Egnatia Under Ottoman Domination.] Istanbul: Tarih Vakf1 Yurt Yayınları, 1999.

Url-1http://enezkazisi.org/?post_type=portfolio\&p=3096\&lang=en).

Url-2www.archieve.aramcoworld.com/issue/201504/egnatia-map/tablet/index.html.

Url3https://www.eydamth.gr/lib/articles/newsite/ArticleID_677/OXE_Egnatia_final.pdf.

Url-4https://www.travel-zone-greece.com/blog/roads-lead-philippi-history-greatly travelled-via-egnatia/.

Url-5http://peutinger.atlantides.org.

Url-6https://www.gettyimages.com/.

Url-7https://www.aramcoworld.com/en-US/Articles/July-2015/Via-Egnatia-to-Rome-andByzantium.

Url-8http://www.persee.fr/doc/bch_0007-4217_1974_num_98_2_4838.

Url-9https://www.viaegnatiafoundation.eu/. 


\title{
Seljuks Inherit to Anatolia; Caravanserais
}

\author{
By Tuğģe Darendeli ${ }^{*} \&$ Can Şakir Binan ${ }^{ \pm}$
}

\begin{abstract}
The history of Anatolia intertwined and layered manner is composed of many historical mosaic of culture. In this chronology, we see the Anatolian Seljuk State in the administration of the era when Turkish identity was set up in Asia Minor. This state has become an important force especially in the $11^{\text {th }}$ and $13^{\text {th }}$ centuries, even if it is not absolute in commercial, military and economic. At that time, the continuity of the state union was due to the intense trade and lack of scarcity in the country. The Seljuks were aware of this. With the expansion of Anatolian Seljuk State borders, which gives importance to the trade, new road networks have been formed and the existing ones have been strengthened. Old Anatolian cities such as Konya, Kayseri, Sivas and Erzurum have become important trade centers. It is necessary to ensure the safety of the roads and caravans in all of this commercial activity in the country. Caravanserais and khans were constructed on the roads to meet the needs of the caravans in order to stay and to continue their way. These buildings, which have an enclosed architecture with thick masonry walls, look like a castle and have become a power show. Anatolian Selcuklu period caravanserais show different features than the previous accommodation structures. In this study, the change of the commercial activities and accommodation during the history and the spatial organization, plan typologies and functions of the Anatolian Seljuk Caravanserai constructions are discussed.
\end{abstract}

\section{Development of Historical Roads and Trade Concept}

Since the beginning of history roads of economic, social and military terms it has had a great importance all the time. Transportation of commodities, military movements and communication between societies have always been achieved through means. Therefore, all civilizations throughout history have made great efforts to maintain their power. The roads have continued to exist in every period of mankind. With the development of mankind and civilizations, paths have also developed.

People used the natural ways of shaping animals in the early times. These roads, also known as 'goat roads' formed by animal tracks, have been transformed into patrols and pedestrian paths with increasing use over time. Some of these roads are also the basis of today's roads. ${ }^{1}$

Bridges, caravanserais and other accommodation structures, towers, landmarks, postal organizations and similar structures have been the most important elements in understanding the ways the caravans have passed. The shortest, most reliable and unstable routes between the two points were determined

*Research Assistant, Yildiz Technical University, Turkey.

\pm Professor, Yildiz Technical University, Turkey.

1. E. Çetin, "Franz Taeschner'in Muhtelif Devirlerde Anadolu'nun Yolları Ve Cihan Münakalatına Nazaran Vaziyeti İSsimli Eseri ÜzeriNe Notlar,” Tarih Okulu Dergisi 17 (2014): 324. 
when the routes were formed. Being close to water resources is important in terms of the location of the roads and settlements, such as land ruggedness, desert, climate. ${ }^{2}$ These roads have taken many years to form.

Some roads have gained importance in some periods of history. The routes used have changed for various reasons and have been characterized by various names in the period. Some of these routes, named according to the commercial goods they carry and their functions. Examples of these routes are the Hittites, the roads of the Assyrian trade columns, the Persian King Road, the Roman Road and the Byzantine road network, and the Silk Road (see Figure 1). ${ }^{3}$

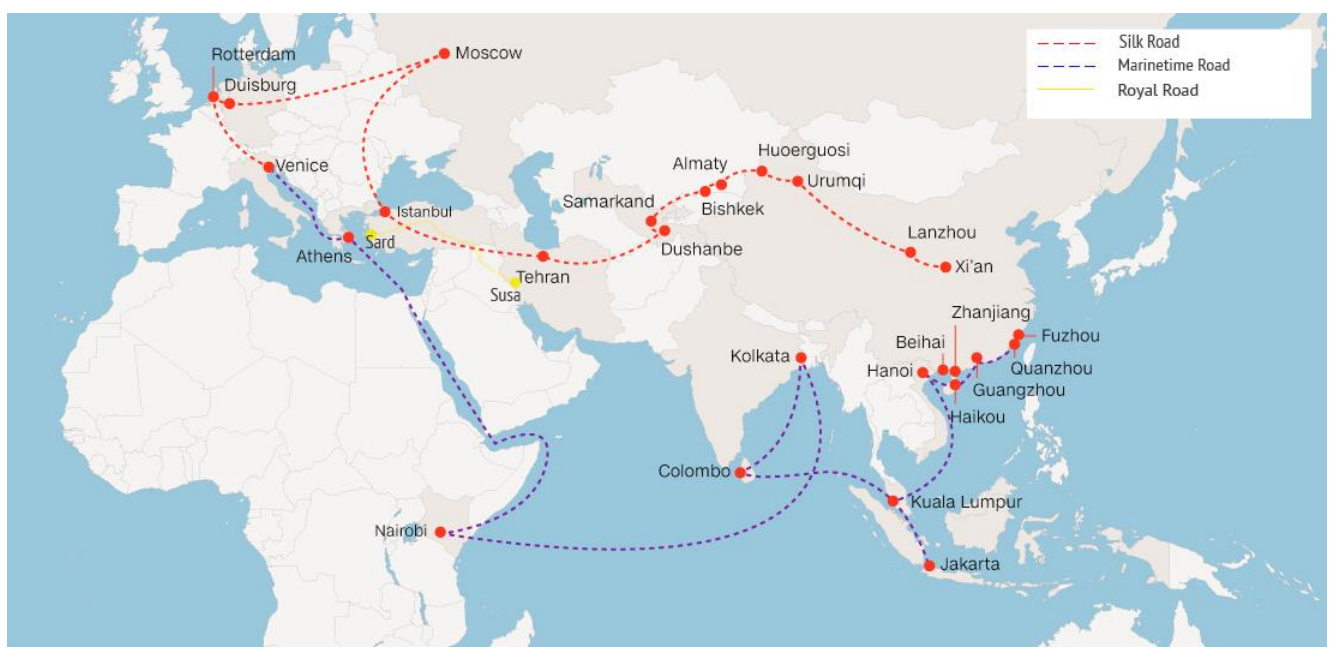

Figure 1. Important Historical Trade Roads

Source: https--financialtribune.com-articles-economy-business-and-markets-64638-iran-s-role-innew-silk-road-emphasized.

\section{Chronological Investigation of Architectural Buildings of Historical Accommodation Structures}

As you can see in every period of trade, there are ways, depending on supply and demand. With the development of roads, cities, states, countries and continents are connected. These travels within the country or between countries have been quite long and difficult. These trips, which last for days and sometimes months, have been made at certain distances to accommodate the caravan's accommodation and needs. Another aim of these structures was to protect caravan's property and life safety. The architectural characteristics of the accommodation structures, plan schemes and functions vary according to various periods and the conditions of the period. $^{4}$

The name Mansiones Veredariorum was given on the commercial roads in the

2. F. Atasoy, Yükselen İpekyolu 3 (Ankara: Türk Yurdu Yayınları, 2016), 103.

3. E. Karacan, S. Karacan and Y. Güngör, "Tarihsel Süreç İçinde Konaklama Merkezleri Han ve Kervansarayların Günümüzde İpek Yolu Projesine Dönüşümü,” 5.Doğu Akdeniz Turizm Sempozyumu ve I. Uluslararası Doğu Akdeniz Turizm Sempozyumu, Nisan, Doğu Akdeniz Üniversitesi Turizm Fakültesi, KKTC, 2016, 3.

4. A. Baş, Beylikler Dönemi Hanları (SÜ, SBE, 1989), 21. 
Romans. These structures were built about $75 \mathrm{~km}$ from each other. These structures, from the first official buildings of the Romans, along with functions such as the accommodation of the travelers and the caravans, shelter of the animals as well as provided the road safety of commanders and statesmen. ${ }^{5}$ But they were devastated over time because they were built on a small scale and with weak structure. The Sangarios Bridge in Adapazarı can be an example of the 'Mansiones Veredariorum' structure, which is made up of vaulted spaces on the east side. ${ }^{6}$ (See Figure 2).

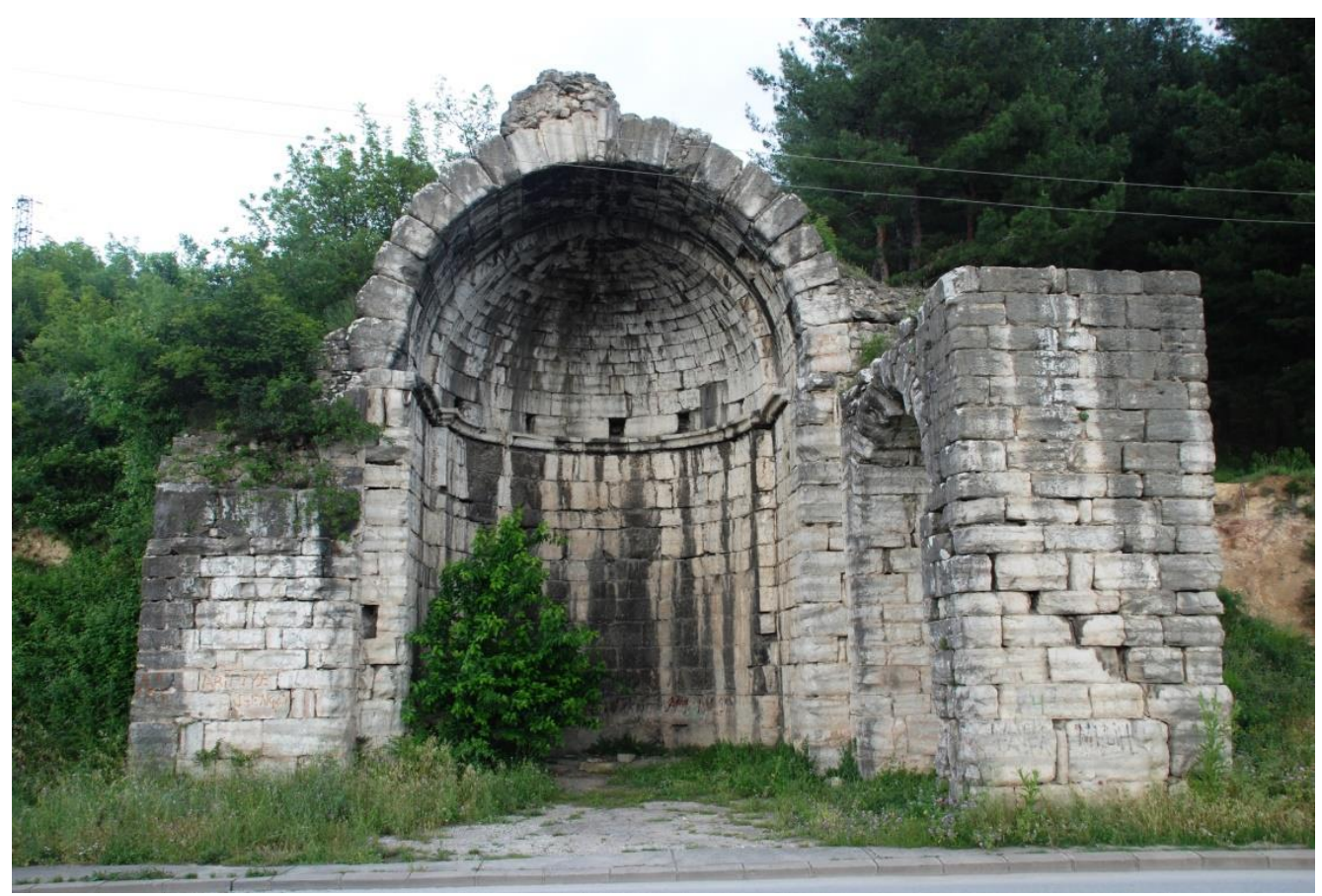

Figure 2. Structure that is Thought of as a House near the Justinianus Bridge, Adapazarl

Source:https://tr.wikipedia.org/wiki/Dosya:Sangarius_Bridge,_Justinyen_K\%C3\%B6pr\%C3\%BCs $\%$ C3\%BC.JPG.

In areas close to the border during the Roman period especially in the $4^{\text {th }}$ century, castrum for the garrison was built in strategically important regions. Generally, these structures were made in Mesopotamia to defend against Europe from the west, and Persian from the east.

Some of the castra with axially symmetrical planes in the center were later transformed into settlement centers by the expansion of the boundaries. Towers were built at regular intervals on long facades. In some sources, it was said that

5. S. Karacan, E. Karacan and Y. Güngör, "Osmanlı'da Konaklama Hizmeti Veren Yapılardan Gebze Çoban Mustafa Paşa Kervansaray1," III.Disiplinlerarası Turizm Araştırmaları Kongresi Bildiri Kitab1, III.Disiplinlerarası Turizm Araştırmaları Kongresi, 2014, 845.

6. C. Binan, 13. Yüzyıl Anadolu Kervansarayları Koruma Ölçütleri üzerine Bir Araştırma. Doktora Tezi (İstanbul: İTÜ Fen Bilimleri Enstitüsü, 1990), 242.

7. Türkiye Diyanet Vakfi İslam Araştırmaları Merkezi [Religious Foundation of Turkey.] http://www.islamansiklopedisi.info/dia/ayrmetin.php?idno=240237. Center for Islamic Studies, June 1, 2018. 
the accommodation was also inspired by Roman's castrum and Sasani's structures. Müller likened the scrolls in the castles to the corners of Iranian caravanserais. Rahmi Hüseyin Ünal mentioned that the Daya Hatun Caravanserai, located in Turkmenistan, reminds of the courtyards of the castles of the porticoed courtyard typology (see Figures 3-4).

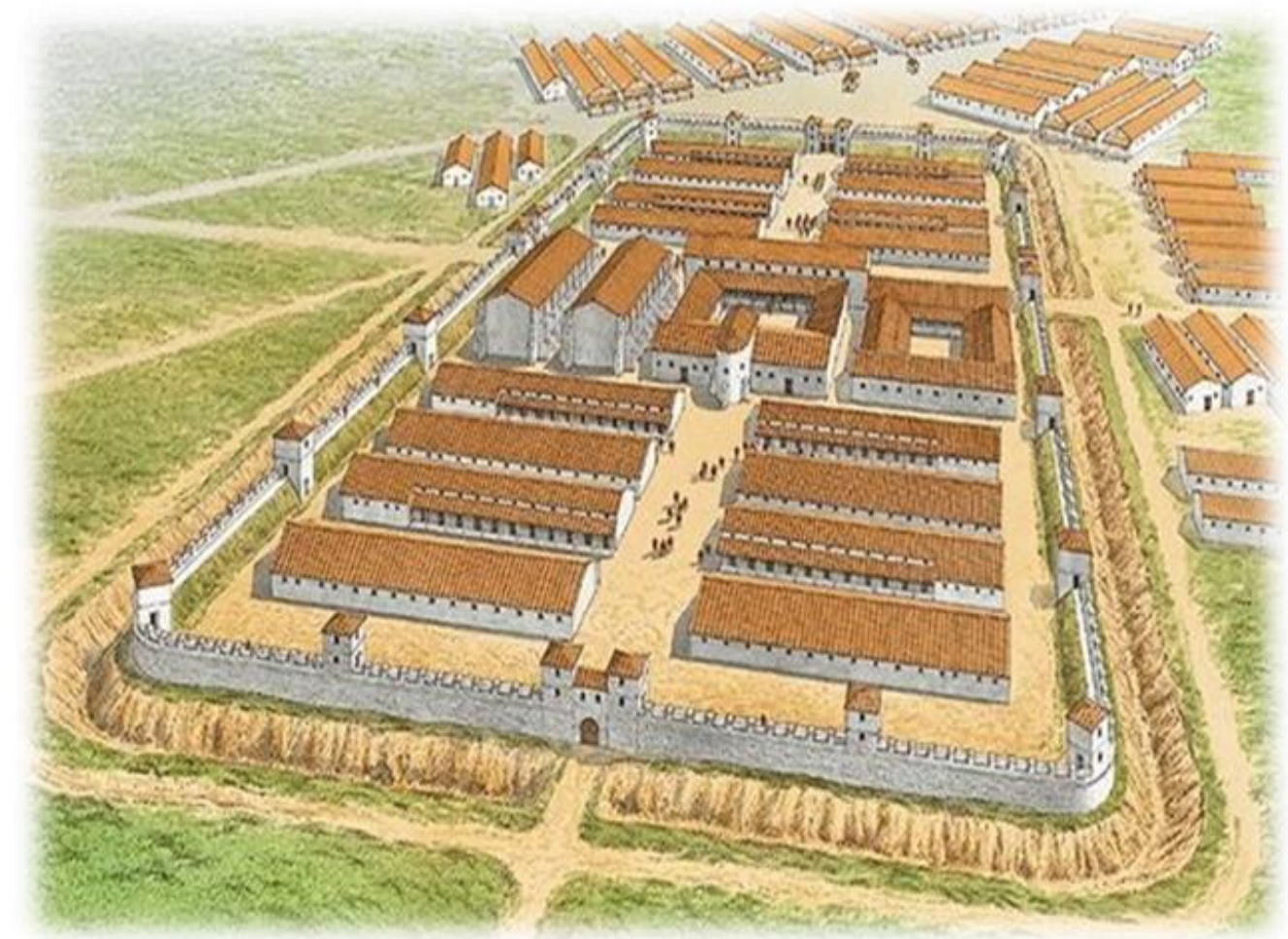

Figure 3. Roman Castra Schematic Visual

Source: https://tr.pinterest.com/pin/290763719686938530/. 


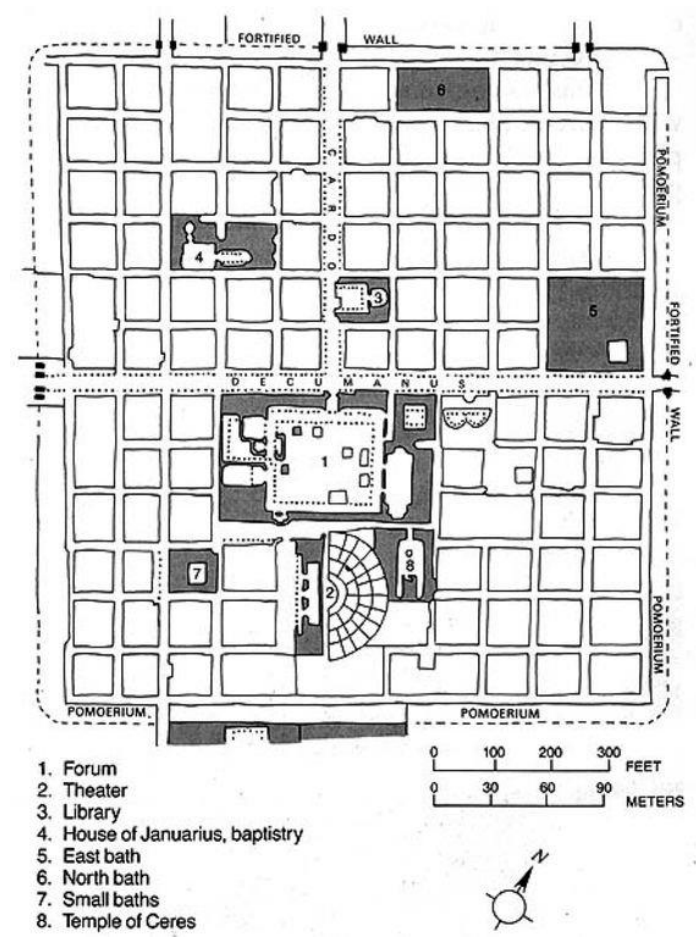

Figure 4. Plan of Roman Castra

Source: https://tr.pinterest.com/pin/574631233679187911/?lp=true.

During the Byzantine era, the accommodation was named 'Xenodochium'. According to Texier, these buildings are the basis for caravanserais and urban khans. ${ }^{8}$ The distance between these accommodation structures located on important and crowded roads under the rule of the Byzantine Empire is about $50 \mathrm{~km}$. ${ }^{9}$ The distance between the constructs takes 8-10 hours on foot. Given the average speed a person will reach on foot; approximately $38-40 \mathrm{~km}$ is the route that the caravan will take in a day. It's a range. The caravans walked one day and stayed in the place they had stayed that night and continued on their way again in the morning. The $50 \mathrm{~km}$ average here is an average expression. The point to be noticed here is that the road condition, geography, season and climate conditions should be considered. According to this, the road can be lengthened or shortened.

Marco Polo mentioned that there were many main roads to the east of Europe in the 8th century and the existence of towns $25-30 \mathrm{~km}$ from each other on these roads. In these towns there are post offices 'jambs' to meet the needs of the passengers. The stations were spacious accommodate the statesmen of the period and even the kings. The needs of these stations have been met by the nearest town and they have said that there are 400 horses ready. Another name for the stations, Jamb, it is of Mongol origin according to Lemke. In Persian, it means the same as 'jan' which means guest house or postal stations. ${ }^{10}$

Historic structures on roads were also found to stay in Mongolian. Mongol

8. Binan, Yüzyıl Anadolu Kervansarayları Koruma Ölçütleri üzerine Bir Araştırma, 1990, 243.

9. Karacan, Karacan and Güngör, “Osmanlı'da Konaklama Hizmeti Veren Yapılardan Gebze Çoban Mustafa Paşa Kervansaray1,” 2014, 845.

10. Ibid, 846. 
emperor Ghengiz Khan built postal station on main roads taking samples from Chinese. $^{11}$

In the $7^{\text {th }}$ century B.C. there are 68 khans built between China and the Uyghur State for military purposes. Emel Esin mentioned about the existence of military fortresses and fortresses in order to ensure the safety of the roads in the commercial caravans and to control trader's property. Mustafa Cezar says that some of these inns are made by the Chinese and some by the Turks. ${ }^{12}$ Today is also called the 'Tchan' these structures in China. ${ }^{13}$

Another example of historical accommodation is ribatlar; In the period between 8th-11th century and the strengthening of the Islamic state, it emerges to the north of Central Asia and Africa. Ribat is derived from the root of the RBT in Arabic, which means order, obedience, direction, regulation, control, heartiness, vigilance in the important place. ${ }^{14}$ As you can see, word root is not about accommodation.

Iran, Mesopotamia, Transoxiana (Mā Warā' al- Nahr) lands were seized when Islam spread. It has long and difficult processes to keep this place in its possession. Iran, who had just met with Islam, created control units at the border to protect the authority in Transoxiana and to ensure the safety of the roads. These cities, which are important in terms of military and administration, have been brought in by experienced and certain members of the family who dominate the region. ${ }^{15}$ It is understood from these expressions that the ribats were built at the border of the military and religious center in the early days of Islam. Many fortresses were built on the military road where the ribats were located or a settlement center was built. Especially in the structure of the castle, it goes back to Merve Part Sassanian period. Although there is a difference in functioning between these qualities and ribats, the space organisms resemble each other. Some of the remains of the Sassanian period were also used for defensive purposes during the period when the region was Islamic. One of these remains is Çilburç Castle, which was used in the Seljuk Period. ${ }^{16}$ This structure has not reached to daylight.

With the strengthening of the Islamic state, new lands were seized in Central Asia. As the surface area grows, new borders have formed and new defenses have been built on these borders. In particular, the number of defense structures called ribat in the Transoxiana region has increased. According to Ibn Hallikan, 10,000 ribats were built in the Transoxiana region. After expanding the borders, the bibs remaining in the inner parts have lost the castle function and have been used with different functions such as accommodation and trade. ${ }^{17}$

The general plans of the Ribat are composed of spaces that meet needs such

11. Ibid.

12. Baş, Beylikler Dönemi Hanlarl, 1989, 21.

13. Karacan, Karacan, Güngör, "Osmanlı'da Konaklama Hizmeti Veren Yapılardan Gebze Çoban Mustafa Paşa Kervansaray1,” 2014, 846.

14. S. Sönmez, "Ortaçağ Türk ve İslam Dünyasında Kervansaraylar (Hanlar - Ribatlar,)" Kâzım Karabekir Eğitim Fakültesi Dergisi, Erzurum (2007): 274.

15. Ibid, 275; O. Turan, "Selçuk Kervansarayları," T.T.K. Belleten X/39 (1946).

16. Atasoy, Yükselen İpekyolu 3, 2016, 119; H. R. Ünal, “Antalya-Korkuteli Kervan Yolu Üzerinde Bilinmeyen Üç Han,” Sanat Tarihi Dergisi XIX/1 (2010): 61-62.

17. Baş, Beylikler Dönemi Hanlart, 1989, 22. 
as warehouses, stables, mosques, shaped around a courtyard in the middle. Another important feature of the Ribats is the spectator lifts, which are also used as minarets. ${ }^{18}$ When viewed from the outside, it is surrounded by high walls, providing a strong appearance. The soldiers used to serve as defense structures and were prepared for the campaigns.

The oldest biblical example that came up to the sun is the building remains in Timriz (Uzbekistan), also known as the caravanserai, dating to the $8^{\text {th }}$ century. It forms a massive mass with the masonry walls and reinforcements at its corners. Sousse Ribat, one of the oldest examples, was built in 821 AD. It is important for the understanding of the ribat architecture that the plan and the architectural features of the building are now available for reading. It has a rectangular plan and there are towers in the middle of the walls at the corners of the structure (see Figures 5-7). It is two floors and there is no visual communication outside the window of masjid. ${ }^{19}$

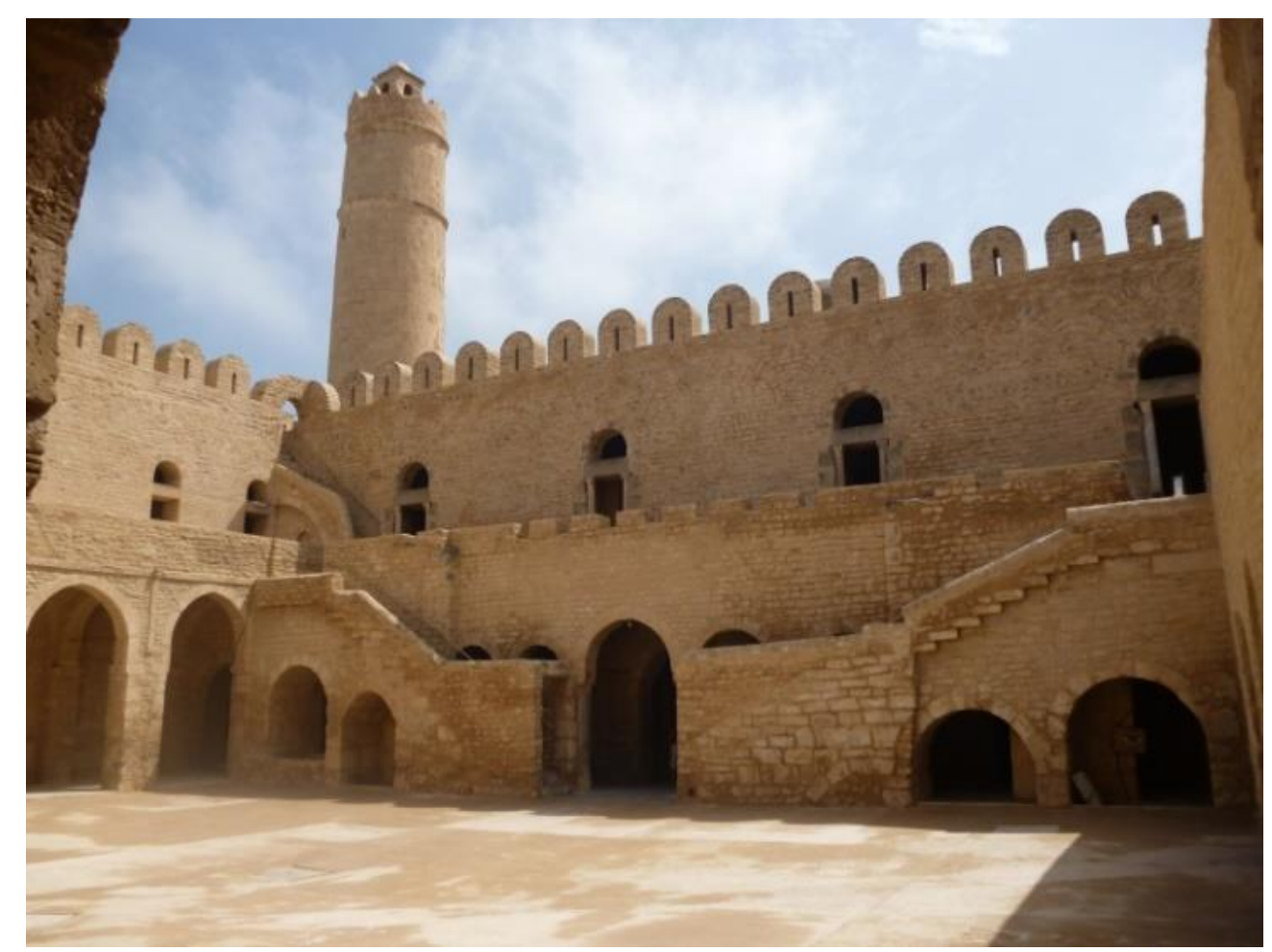

Figure 5. Sousse Ribat, Tunisia Courtyard and Tower

Source: https://en.wikipedia.org/wiki/Ribat_of_Sousse\#/media/File:Medina_of_Sousse-130323.jpg.

18. Ibid, 23.

19. Ibid. 


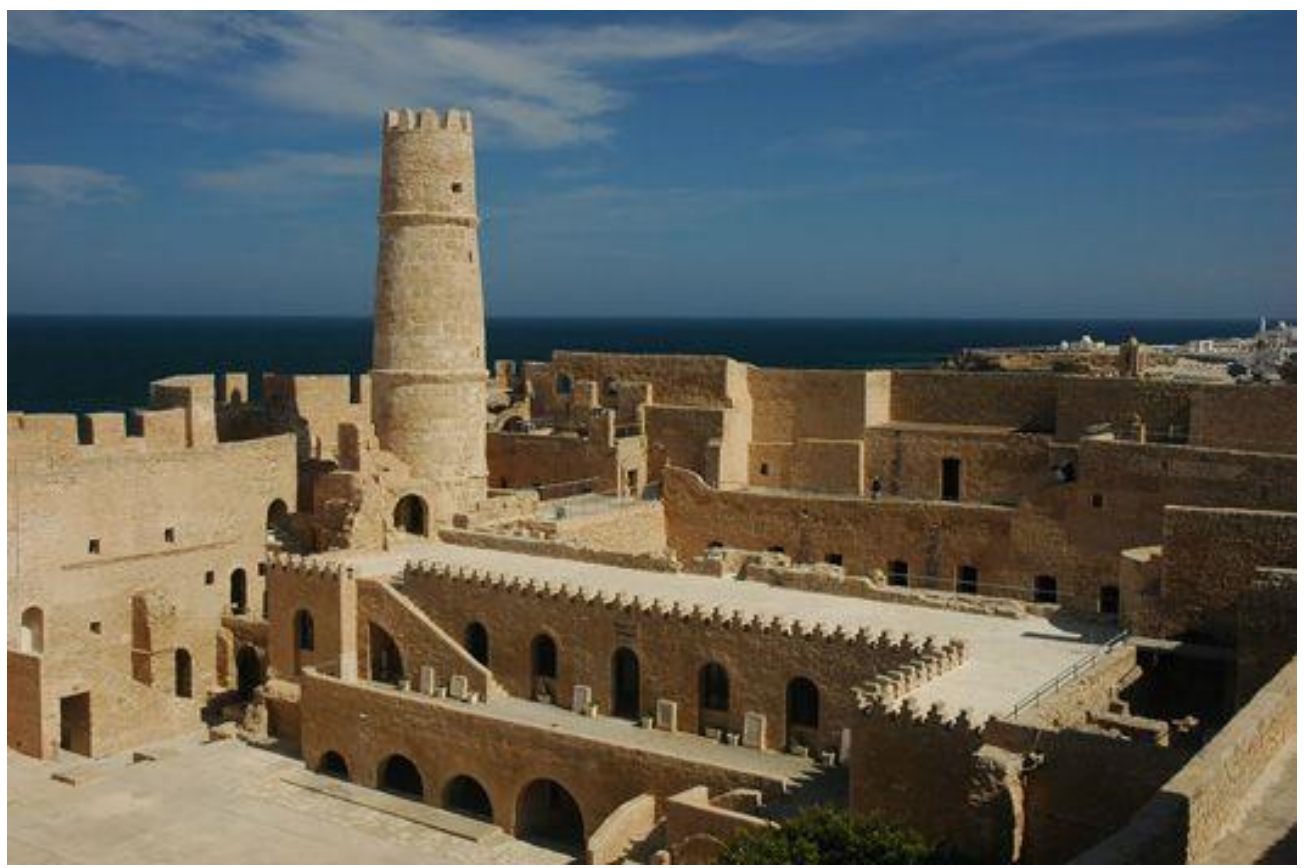

Figure 6. Sousse Ribat, Tunisia General View

Source: https://tr.pinterest.com/pin/488570259551849184/?1p=true.

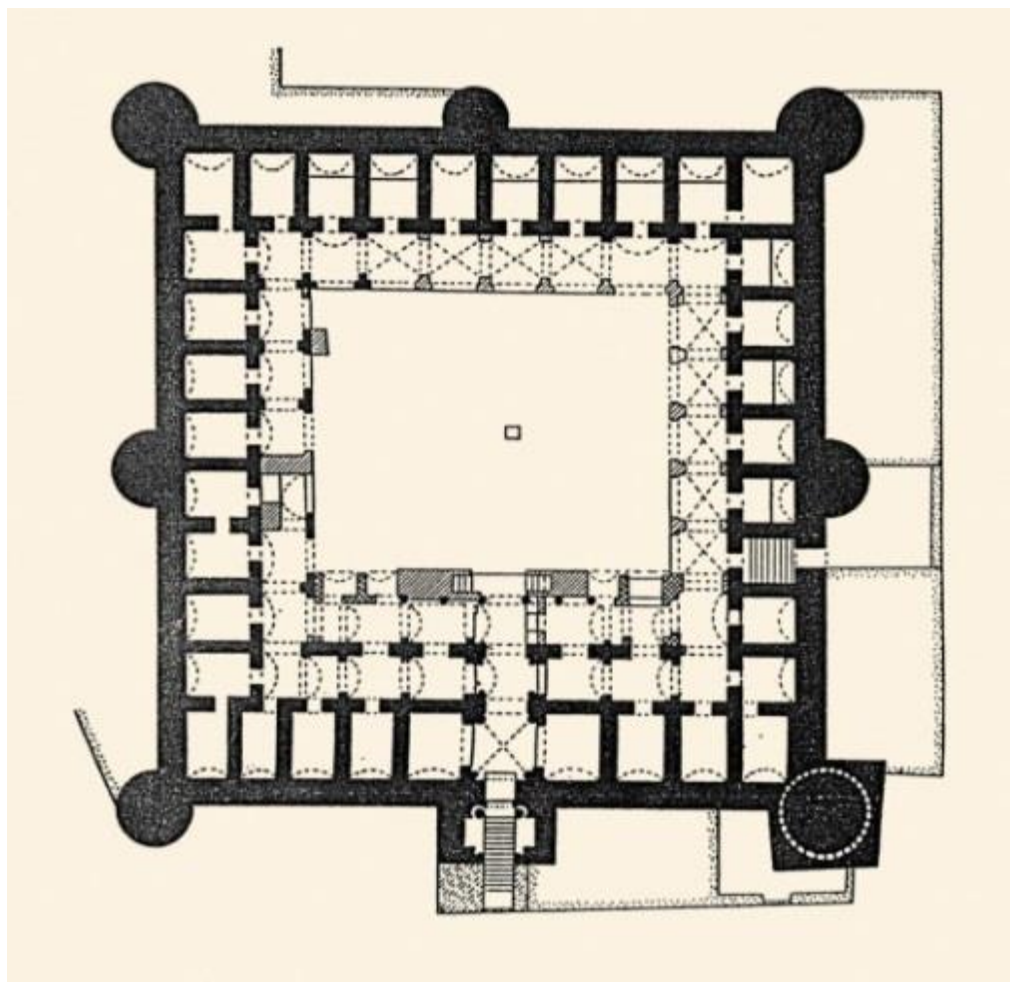

Figure 7. Sousse Ribat, Tunisia Plan

Source: https-_islamansiklopedisi.org.tr_suse-ribati.

In the $8^{\text {th }}$ century, the functions of the ribats that built on the border with the defense purpose have changed with the spread of Islam and the expansion of the 
boundaries of the Arabs, in the $10^{\text {th }}$ century, the trade routes and main road network in the Transoxiana region are now covered by the country's land. The defending ribats became a meeting place for accommodation stations or religious meetings. This is also the case for the definitions of lodge, 'zaviya'*, fortress. ${ }^{20}$

The Turks were usually influenced by the culture and civilization of the Arab geography by meeting with Islam and gradually accepting Muslims. There have been many architectural influences. One of them has also been ribats that continuing the accommodation function. In the first Muslim Turkish states, khans and caravanserais were called ribat. The first ribat in Turks were built during the Karahanlı's and Gazneli's era. The earliest example of ribat is Ribat-1 Mahi, which was built by Gazneli Mahmud between 1019-1020. The other one is Ribat-1 Melik, which was built between the years of 1079-1080 in Karahanlı's period ${ }^{21}$ (see Figures 8-9).

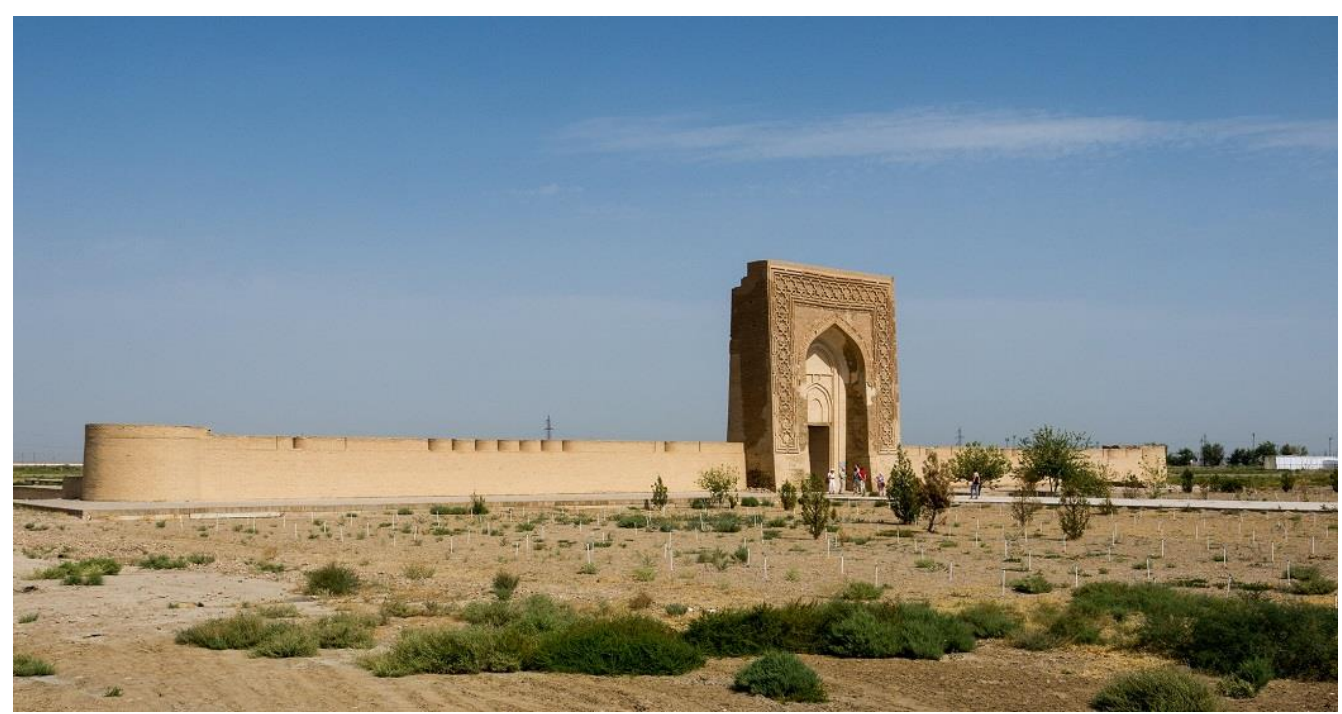

Figure 8. Ribat-ı Malik General View

Source: https://okuryazarim.com/ribat-i-melik-kervansarayi/.

20. Binan, 13. Yüzyll Anadolu Kervansarayları Koruma Ölçütleri üzerine Bir Araştırma, 1990, 243.

21. Baş, Beylikler Dönemi Hanlarl, 1989, 23. *Zaviya: Place of Sufism Education. 


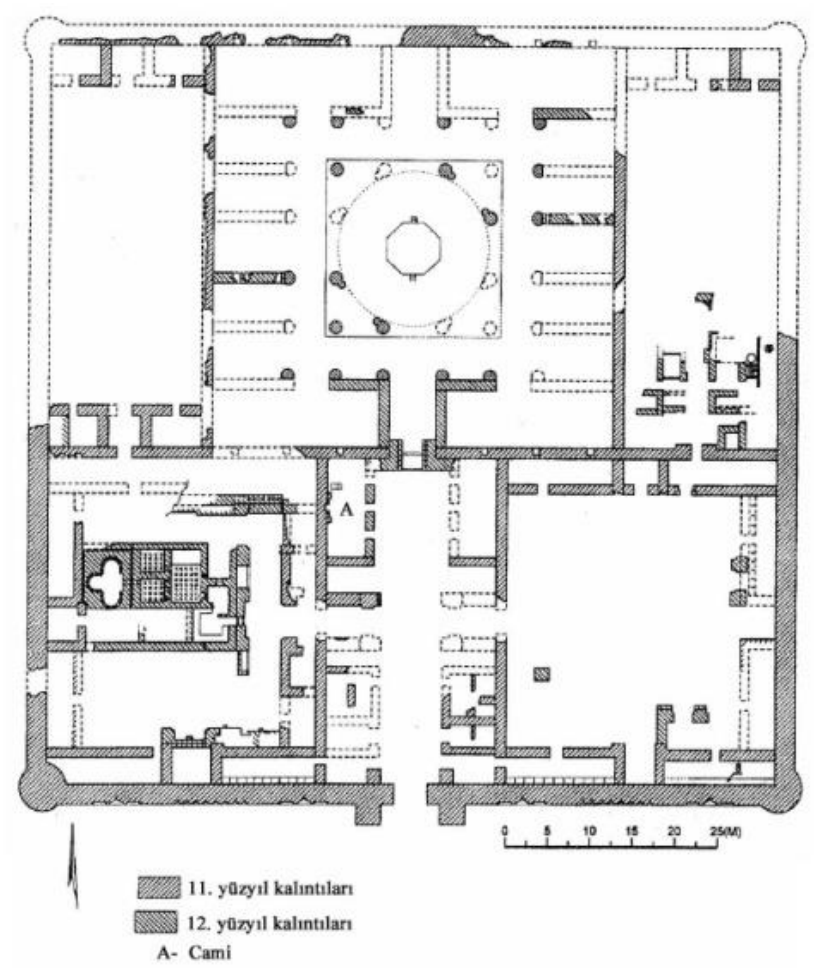

Figure 9. Ribat-ı Malik Plan

Source: https://okuryazarim.com/ribat-i-melik-kervansarayi/.

\section{Seljuk Period in Anatolia and Anatolian Seljuk Caravanserais}

By the arrival of the Turks to Anatolia, Turks took the place of the Arabs in the battle with Byzantium. By the end of the $11^{\text {th }}$ century, the Byzantine was weakened. In Anatolia commercial life has lost its former vitality and roads have been used for military purposes. ${ }^{22}$

The demographic and political structure of Anatolia has begun to change and it has faced more with Byzantine and European Turks. After Malazgirt Turks started to come to Anatolia (see Figures 9-10). Anatolian roads deserted with the use of the sea route over Egypt in the centuries have been revitalized with the provision of road safety. ${ }^{23}$

Seljuk State knows the importance of trade and trade routes of Anatolia, Seljuks gave importance to the security and development of the road. Black Sea and the new ports and ports in the Mediterranean by establishing the city of trade, Anatolia, the interior has allowed them to enter. Caravan trade is not only in the form of taking and leaving goods, but in every point of residence there is a commercial activity and a development in the places where it is hosted enriches

22. Binan, 13. Yüzyll Anadolu Kervansarayları Koruma Ölçütleri üzerine Bir Araştırma, 1990, 14.

23. Baş, Beylikler Dönemi Hanları, 1989, 8. 
Anatolian cities. $^{24}$

A lot of work has been done to keep the commercial life alive and to ensure road safety. At the beginning of the $13^{\text {th }}$ century Antalya was taken over by Giyaseddin Keyhüsrev and worked to become a free trade center. Faced with the low cost of maritime trade, many conveniences have been provided to direct traders to land trade and to stimulate land trade and to encourage local and foreign merchants. The deal was signed with the Venetians, the main trading state, and the taxes in the ports were removed. Trade agreements with foreign states have been made. $^{25}$

When we look at the existing road route during Anatolian Seljuk period; with Konya being the capital city we see that the road network started from İstanbul and left Konya in the southeast and northeast direction. One of these roads reached the Antakya from the Gülek Passing by going south. The other way was to go from Kayseri, Sivas, Erzurum and then Iran to the north-east of Konya. ${ }^{26}$

During the Seljuk period, the northern southern line in Anatolia also came from the most important road routes. Especially after the $13^{\text {th }}$ century, this route, which has increased in importance, has been connected to Trabzon through the Black Sea via Sivas and Malatya, a road network starting from Baghdad and Aleppo. Sivas was the intersection of the roads leading to these three regions and the 11th-13th. It has become an important trade center for centuries.

The transit route from here to Iran, where Trabzon is an important port in the $12^{\text {th }}$ and $13^{\text {th }}$ centuries, has directed the Seljuks to the Black Sea ports. The Seljuks wanted to seize the ports of Sinop and Samsun and to pass the commercial road network from Anatolia. Sinop was seized in 1214 to connect the Black Sea ports to Anatolia. With the Armenian kingdom in Cilicia threatening Aleppo, 1214 Aleppo flights were made and the road was opened to safe traffic. Located between Kayseri and Malatya, 'Yabunlu Bazaar' is an international fair. This shows how active Anatolian trade is in that period. ${ }^{27}$

With the seizure of Sinop and Alanya, the road to Iran from Alanya, Antalya, Konya, Aksaray, Kayseri, Sivas, Erzincan and Erzurum entered into Seljuk control. The same road separates south from Sivas; Malatya, Diyarbakir, Mardin, Mosul to Baghdad and Basra. Another road network starting from Istanbul was reached from Izmit, Iznik, Eskisehir, Aksehir, Konya, Ulukisla, Adana, Aleppo, and Damascus to Egypt. As you can see; there are many road networks in the Anatolian lands during the Anatolian Seljuk period. The main road network has been preserved by the topographic and economic conditions; to build trade, caravans have built many caravanserais, inns and ribs to provide road safety and accommodation (see Figure 10.) ${ }^{28}$

24. Binan, 13. Yüzyll Anadolu Kervansarayları Koruma Ölçütleri üzerine Bir Araştırma, $1990,15$.

25. Ibid, 18.

26. Çetin, E., "Franz Taeschner'in Muhtelif Devirlerde Anadolu'nun Yolları Ve Cihan Münakalatına Nazaran Vaziyeti İSsimli Eseri ÜzeriNe Notlar,” 2014.

27. Binan, 13. Yüzyll Anadolu Kervansarayları Koruma Ölçütleri üzerine Bir Araştırma, $1990,16$.

28. A. Eskikurt, "Ortaçağ Anadolu Ticaret Yolları," Sosyal Bilimler Enstitüsü Dergisi, Muğla (2014): 33, 21. 


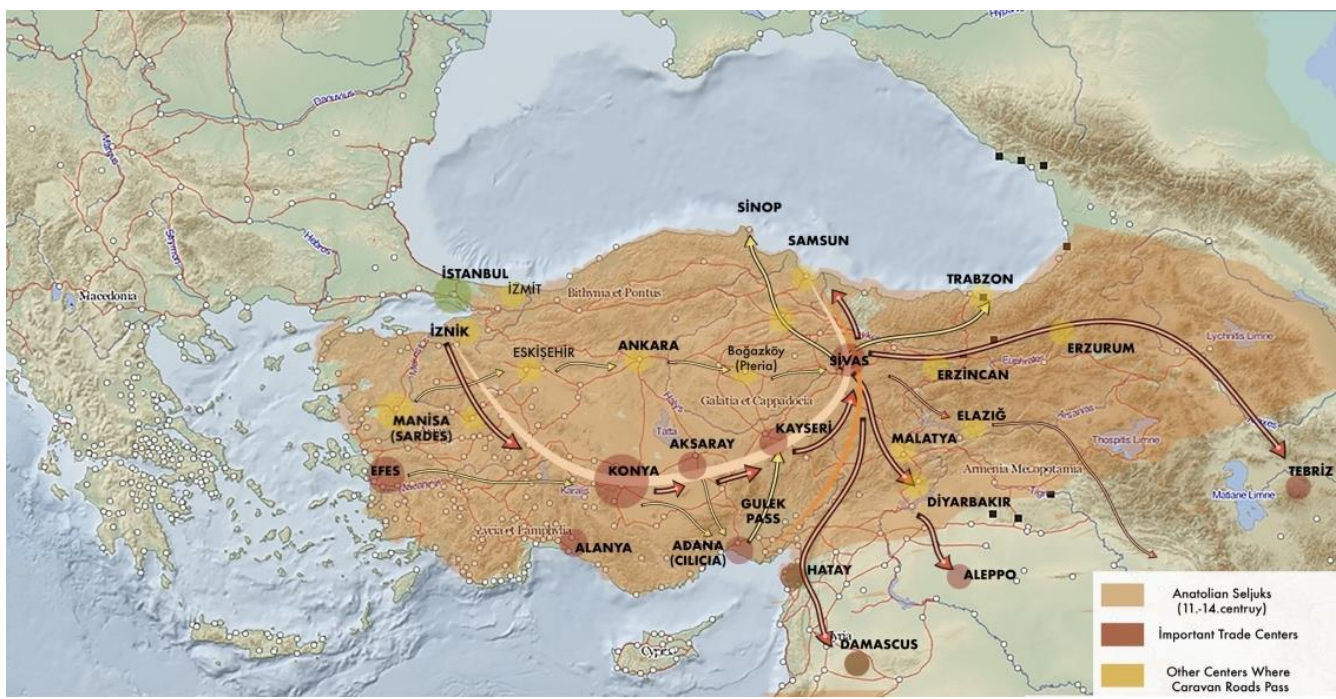

Figure 13. Anatolian Roads in the Seljuk Period

Source: Darendeli, 2018.

As Anatolia has become a transit center in highway trade, cultural exchange has been experienced besides goods and services. The architectural characteristics of various civilizations from Asia to Iran have changed according to the topographic, climatic and administrative conditions of Anatolia and created a unique model. The Seljuks built their own unique culture and civilization with their administrative structures strengthened by their own experience. They have found inventive works in architecture and art. Caravansaries were also the most important examples of this inventive architect (see Figure 11).

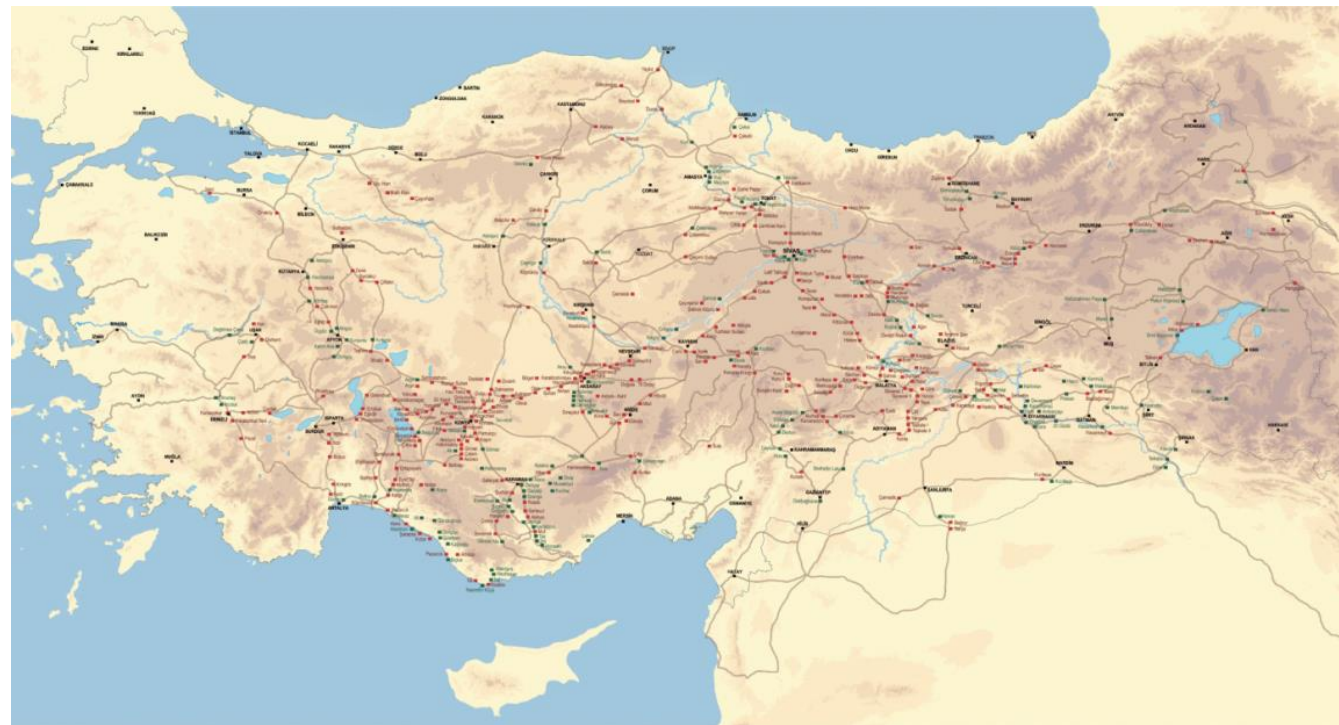

Figure 11. Anatolian Seljuk Caravanserais on Trade Roads

Source: https://www.cekulvakfi.org.tr/haber/ipek-yolu-kultur-yolu-haritasi.

When we look at the origin of the caravanserai term, it is understood that the word "karban" is derived from Persian. "Karban" is the place where the passengers 
are staying and staying overnight; "Karbanserai" means the place where the trader works. Over time this expression has turned into a "caravanserai". It is a structure that allows travelers and caravans to travel from one settlement to another, to meet their various needs, to connect their animals, and to secure the passengers safely until the sunrise the next day.

Anatolian Seljukian period caravanserais and khans, some of the inscriptions (stone tablets) on the name of the building was seen as ribat. This is a sign that the concept of caravanserai and inn is the continuation of ribats. ${ }^{29}$ But in plan design, materials and functions; there have been changes depending on period and geography. Built in Iran and Central Asia between the $10^{\text {th }}$ and $13^{\text {th }}$ centuries, the khans are generally shaped around a courtyard. In the first Turkish states, ribates are generally square or rectangular in plan. It was from the courtyard and the courtyard in the middle of the revolving places. On the four sides, there are "iwan (eyvan)" in the middle. This form has been the continuation of a tradition of home from Central Asia. The building material used is adobe, brick or stone depending on the region. ${ }^{30}$ Anatolian Seljuk caravanserai are very rich in terms of plan schematics. There are only examples of courtyard caravanserai which is the continuation of tradition coming from Central Asia. In addition to this, there are only indoor caravanserai examples which are made according to geographical and economic conditions. In more advanced plan examples, there is a closed space and a courtyard that opens to it. ${ }^{31}$

\section{Foundation Administration and Operation in Anatolian Seljuks Caravanserai}

When you look at the social and cultural structure of the Seljuks, there are two important institutions besides the state structure. These are 'ahilik' and "foundation (waqf)"organizations. Leaders of the state could establish themselves a foundation or donated to the foundation. Depending on the organization of the foundation, more activities were carried out in the country. Khans, caravanserais, bridges, hospitals and madrasahs have been built. Buildings such as mosques, hospitals, caravanserais which are connected to the foundations make their own administration, managed by incomes and donations, and the foundations are not traded. $^{32}$ In the caravanserais connected to the foundation system, the three day expenses of the Muslims and non-Muslims were covered by the foundation. ${ }^{33}$

In Anatolia in the Ottoman period, the road network has changed and some roads have lost importance and deserted. The caravanserais on these roads have been abandoned. Over time, they have been devastated by weather conditions, human-induced causes and non-use. The number of caravanserais in Anatolia that have remained in rural areas and are in ruins is quite high. The most important resources that we can reach the information about these structures are 'foundations'.

29. Baş, Beylikler Dönemi Hanları, 1989, 24.

30. Ibid, 23. 1990, 244.

31. Binan, 13. Yüzyıl Anadolu Kervansarayları Koruma Ölçütleri üzerine Bir Araştırma,

32. Karacan, Karacan, Güngör, “Osmanlı'da Konaklama Hizmeti Veren Yapılardan Gebze Çoban Mustafa Paşa Kervansarayı,” 2014, 846.

33. T. Osman, "Selçuklu Kervansarayları," TTK Belleten X/39 (1946): 471-496. 
As we have seen in Romans and Byzantines, the distance between caravanserais in the Anatolian Seljuks is the distance a caravan can take in a day. Approximately $35-40 \mathrm{~km}$. It is a "manzil". Therefore, the caravanserais are also called the manzil khans. ${ }^{34}$

The city khans are different from the manzil khans and are in harmony with the urban texture. It is usually commercial function. Because cities are surrounded by ramparts and safety is partly provided, there is no need for a defense like in the manzil khans. It usually consists of rows of rooms lined up two floors around a courtyard. The ground floor is used for stables, warehouses and commercial purposes, and the first floors are used for accommodation purposes. ${ }^{35}$

Many khans and caravanserais were built on the roads for accommodation and commerical purposes. Especially in the time of I. Alaeddin Keykubad, the importance of zoning activities was given. Aksaray and Tuzhisar Sultankhan, the most spectacular caravanserais of Anatolia, were built during this period. ${ }^{36}$

\section{Space Organization and Architectural Features of the Anatolian Seljuk Caravanserais}

The Anatolian Seljuk caravanserais are a continuation of Central Asia and have their own architectural solutions. In Anatolian Selçuklu caravanserais, space fiction constitutes two main elements. The courtyards are covered with courtyards. These also vary within themselves. Courtyards; open and semi open spaces. In the closed areas, no parting is done. The function of the room used is understood from the elevations used and the shapes used to serve humans or animals. ${ }^{37}$

The caravanserai built during the Anatolian Seljuk period is a castle view from the outside. The inside, however, is quite lively both commercially and socially. There are places such as overnight accommodation, mescit, hamam, kitchen, infirmary, barn and fountain which will respond to the needs of the caravans. $^{38}$

The location of the caravanserais may differ according to the geography, who made it, and the period. We can say that the enclosed area exists in all. It is understood from the presence of two monumental portals in the structure that the courtyard was later enclosed in courtyard caravansaray. Probably first a closed section was made, a courtyard was made in front of the entrance door in case of improvement of conditions or necessity of people. ${ }^{39}$

Caravanserais in Anatolia are also known by their names of father (bâni). The khan built by the sultans, "Sultankhan" name is given. It is more spectacular and more monumental than the other caravanserais. The Aksaray-Konya road is located on Aksaray Sultankhan and Kayseri-Sivas road is located on Tuzhisarı

34. Baş, Beylikler Dönemi Hanları, 1989, 25.

35. Ibid, 26.

36. Ibid, 10.

37. Binan, 13. Yüzyıl Anadolu Kervansarayları Koruma Ölçütleri üzerine Bir Araştırma, 1990, 246.

38. Baş, Beylikler Dönemi Hanları, 1989, 24

39. Binan, 13. Yüzyıl Anadolu Kervansarayları Koruma Ölçütleri üzerine Bir Araştırma, 1990, 247. 
Sultankhan. The general architectural structure of these two "Sultankhan" was also similar. The courtyard is entered and the enclosed section is passed through the portico units turning around the courtyard. The closed section is not partitioned here as in the more modest examples, but the functional differences are determined by the heights formed in the ground. ${ }^{40}$

Various plan schemes have emerged according to the person, concentration, economic conditions, and climate of the caravanserais. Erdmann collects caravanserais under three main headings. Ayşıl Tikel Yavuz also adds a special typology of the focal points of khans. ${ }^{41}$ In this study, examine caravanserais in 4 main headings according to this information.

Plan Typology

1. Closed Space Planned Caravanserais

2. Closed Space and Courtyard Planned Caravanserais

3. Courtyard Planned Caravanserais

4. Concentric Planned Caravanserais

Closed space planned caravanserais

This plan typology which consists only of indoor space is often unfinished before the courtyards are completed. For this reason it only consists of closed space. There are also khans designed as closed spaces during the first construction period. An example of this is Şarapsa Khan. Between the years 1236-1246 was built during the Sultan II. Giyaseddin Kevhusrev period. ${ }^{42}$ The khan on AlanyaAntalya is also known as "Şarapsa", "Şarabsa", "Sarafşa" or "Sarafsa". The structure consists of a single closed space with a rectangular plan (see Figure 12). This enclosed space is covered with a pointed barrel vault extending in the eastwest direction. A masjid was added to the east side of the structure in the northsouth direction.

40. Ibid, 246.

41. Ibid, 247.

42. Binan, 13. Yüzyll Anadolu Kervansarayları Koruma Ölçütleri üzerine Bir Araştırma, $1990,215$. 


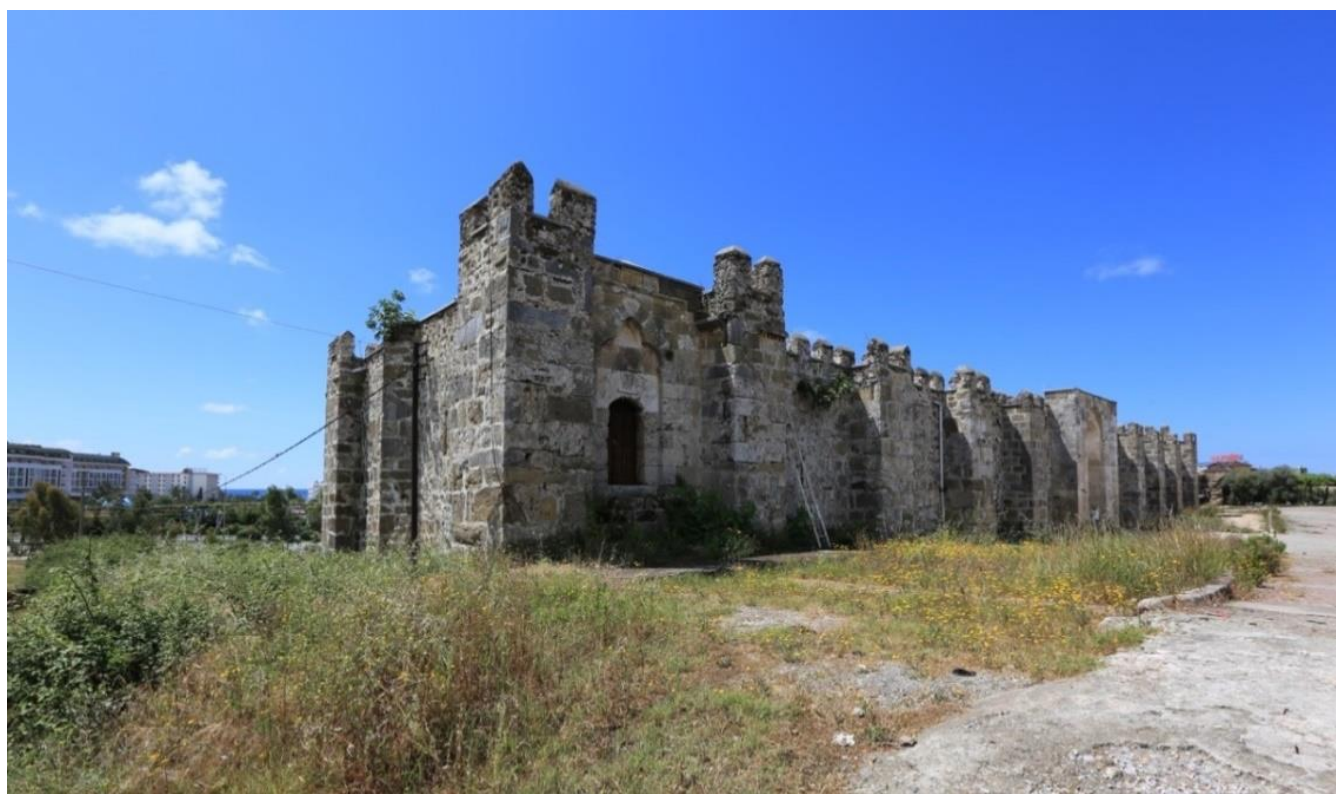

Figure 12. Şarapsa Khan(Antalya) General View

Source: https-//www.semerkanddanbosnaya.com/portfolio/sarapsa-han/.jpg.

The upper cover of the masjid is a barrel vault extending in a north south direction. Structure, with the added mescit portion covers an area of approximately $11.50 \times 71.00 \mathrm{~m}$. The structure which has a long rectangular plan has rectangular shaped struts at equidistant distances on the north and south facades structure having a long rectangular plan is situated equidistant to each other in a rectangular form struts. The eastern and western facades are supported in the middle by triangles in the form of struts. There is a portal on the northern edge of the building that opens into the interior. (See Figure 19) All the facade spinning dykes at the level of the roof gave the building a castle view. ${ }^{43}$ (See Figures 13-16).

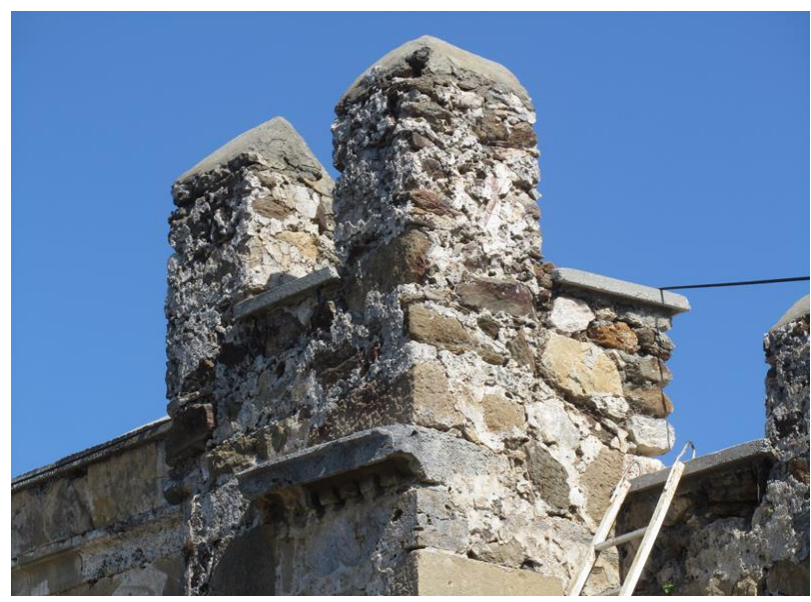

Figure 13. Şarapsa Khan Detail

Source: http://www.anadoluselcuklumimarisi.com/picture/388_18_14.jpg.

43. H. Acun, Anadolu Selçuklu Kervansarayları (Ankara: T.C. Kültür Bakanlığı Yayınları, 2007), 393. 


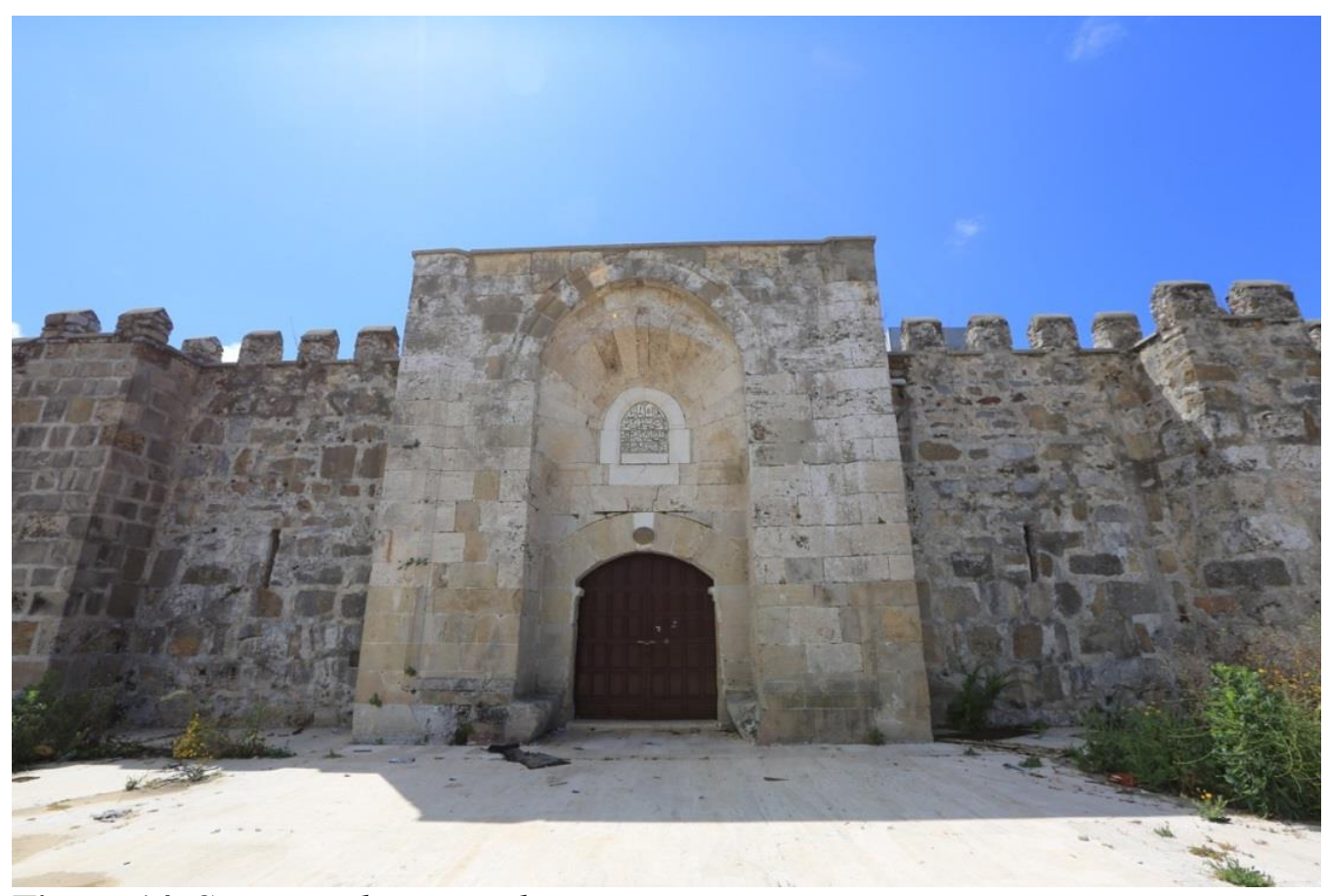

Figure 14. Şarapsa Khan Portal

Source: https-//www.semerkanddanbosnaya.com/portfolio/sarapsa-han/.jpg.

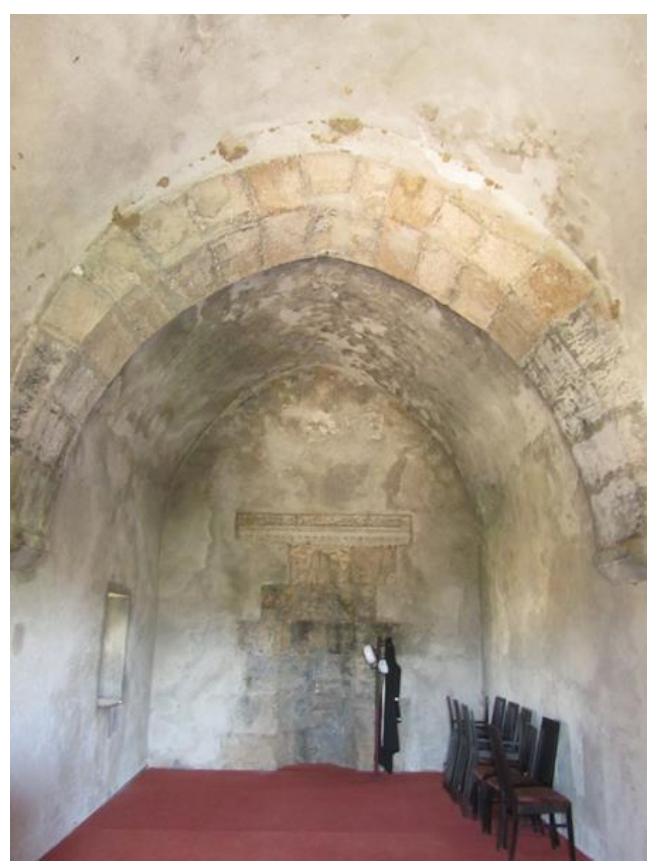

Figure 15. Şarapsa Khan Masjid

Source: http://www.anadoluselcuklumimarisi.com/picture/388_18_17.jpg.

In the walls of the building there are rough cut stone at the crown of the masjid and the khan, and rubble stone used in other parts (see Figure 16). The inside of the wall coverings is filled with rubble and formed a very thick layer. 
Wall thicknesses are approximately $1.25-1.50$ meters. $^{44}$

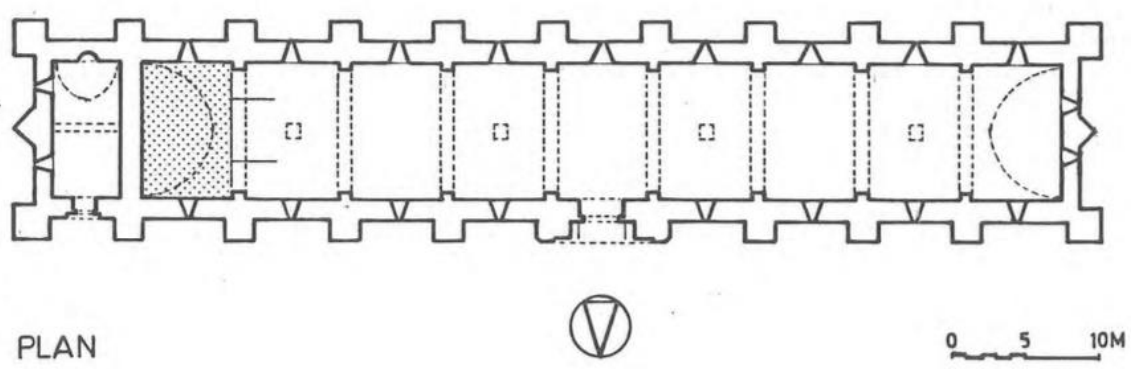

Figure 16. Şarapsa Khan Plan

Source: Binan, C., (1990). 13. Yüzyıl Anadolu Kervansarayları Koruma Ölçütleri üzerine Bir Araştırma, Doktora Tezi, İTÜ Fen Bilimleri Enstitüsü, İstanbul, 223).

Closed space and courtyard planned caravanserais

We can separate subheadings according to vault layouts and space sizes. This plan typology is generally used in Central Anatolia. First, an enclosed space was built and then the courtyard was added due to the improvement of the economic situation and conditions or the need. There are many examples of this plan typology. Aksaray Sultankhan, one of the biggest and most spectacular caravanserai in Anatolia, is also an example of this construction.

Aksaray - Konya on the way to give the name of the Sultankhan district is the first construction date of the building is 1229. It was built by I. Alaaddin Keykubat. The building was burnt down in 1270, repaired and expanded in 1278 . It was later repaired in the $14^{\text {th }}$ century.

The khan consists of a closed space and adjacent to the courtyard. There are two monumental portals in the building. One of them is the entry gate of the courtyard and the other is the entrance door of the closed space. The exterior of the building is made from the crown door that opens to the courtyard. There are a number octagonal section on the eastern front strut around every corner. ${ }^{45}$ The crown gates have reached the size of the day and are largely upright (see Figure $17)$.

44. Binan, 13. Yüzyll Anadolu Kervansarayları Koruma Ölçütleri üzerine Bir Araştırma, 1990, 216.

45. Acun, Anadolu Selçuklu Kervansaraylarl, 2007, 142. 


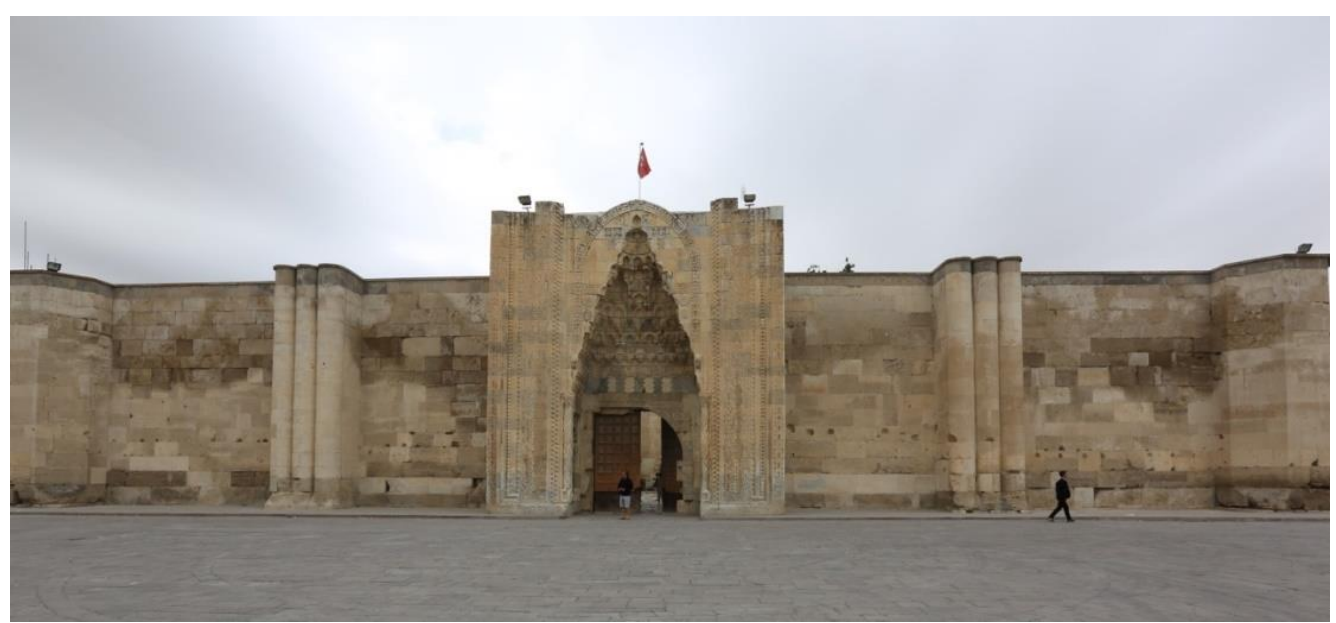

Figure 17. Aksaray Sultankhan East Section and Main Portal

Source: https://www.semerkanddanbosnaya.com/portfolio/sultanhani/.

On the east side, portal opens with a rectangular plan. There is a kiosk masjid in the center of the courtyard. ${ }^{46}$

The kiosk masjid with two-sided twin stepped stairs is square plan. The ruined mosque with its top cover was largely completed in its restoration work since it became ruined over time. ${ }^{47}$ (See Figure 17). It consists of portico spaces surrounding the courtyard. From courtyard passed to closed space. There is a portal that allows passage of the courtyard through the closed space.

There are three main aklands with a rectangular plan extending east-west. The ceiling height of the middle hall in the entrance axis is higher. There is a dome in the central symmetry center. The hall on both sides of the central hall is covered with pointed arches. It is arranged in four rows in the east-west direction and raised on four square piers joined by pointed arches. ${ }^{48}$

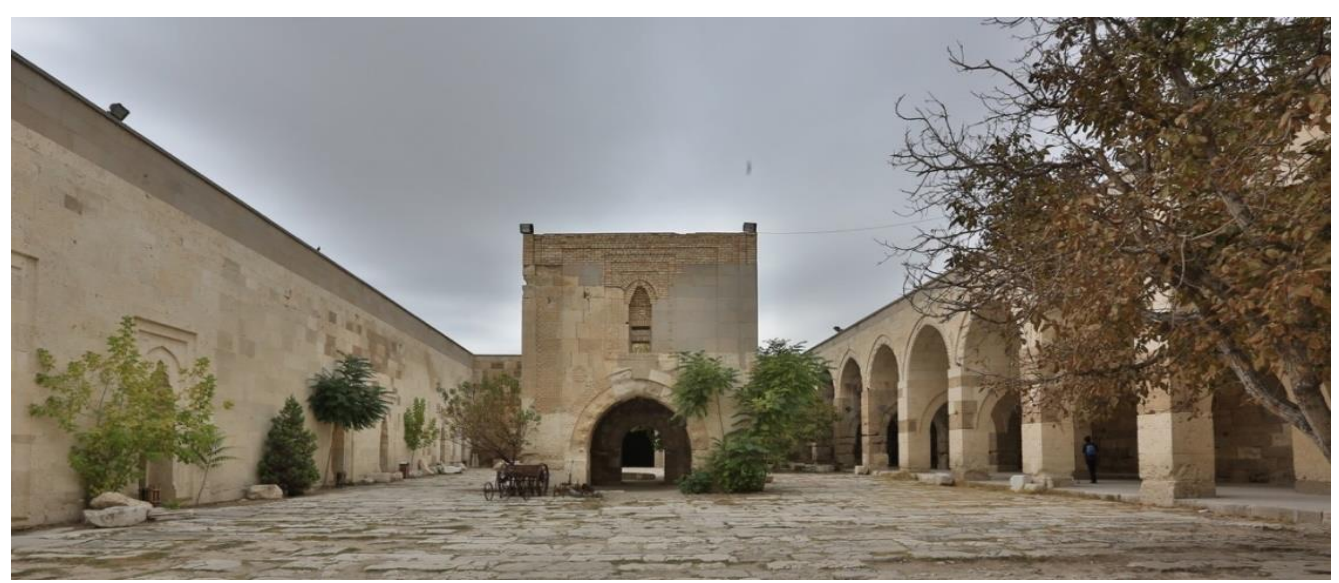

Figure 18. Aksaray Sultankhan Kiosk Masjid

Source: https://www.semerkanddanbosnaya.com/portfolio/sultanhani/.

46. Ibid, 143.

47. Binan, 13. Yüzyıl Anadolu Kervansarayları Koruma Ölçütleri üzerine Bir Araştırma, 1990, 191.

48. Acun, Anadolu Selçuklu Kervansarayları, 2007, 144. 


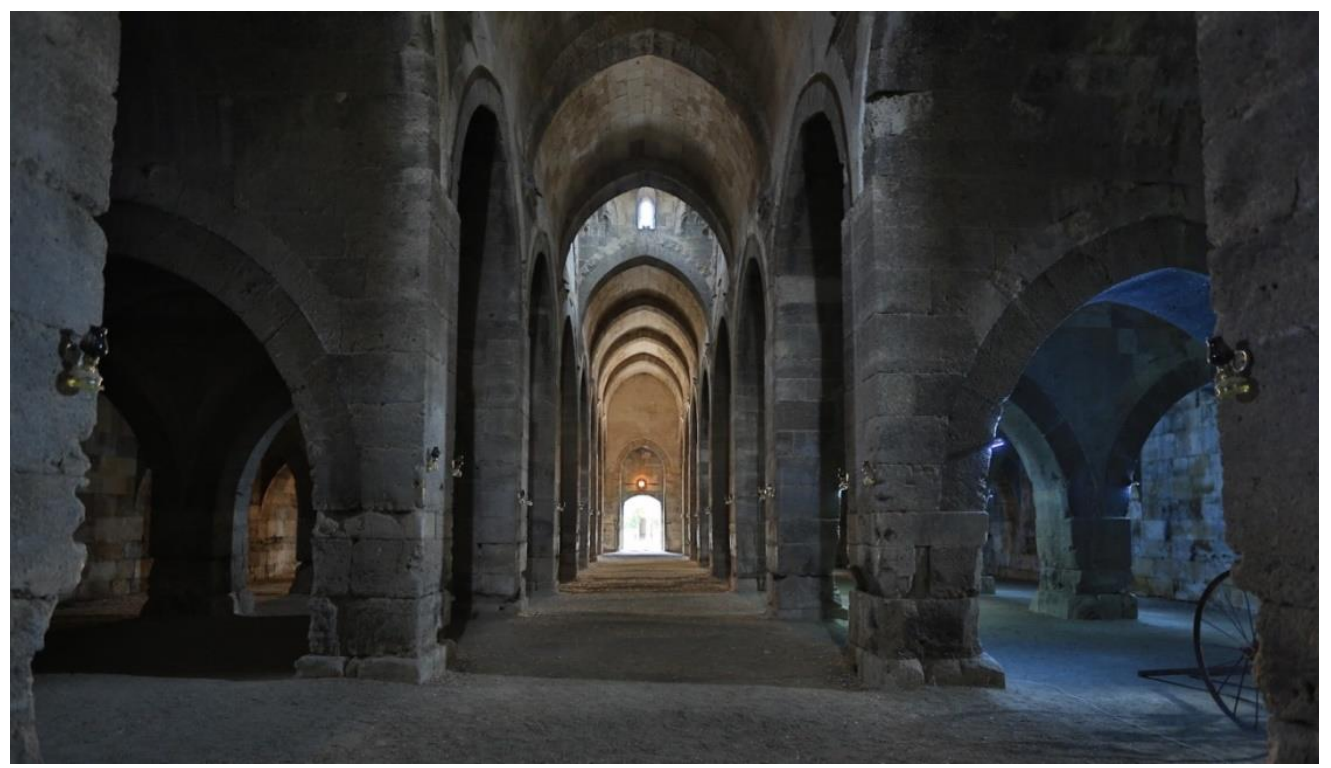

Figure 19. Aksaray Sultankhan Closed Space

Source: https://www.semerkanddanbosnaya.com/portfolio/sultanhani/.
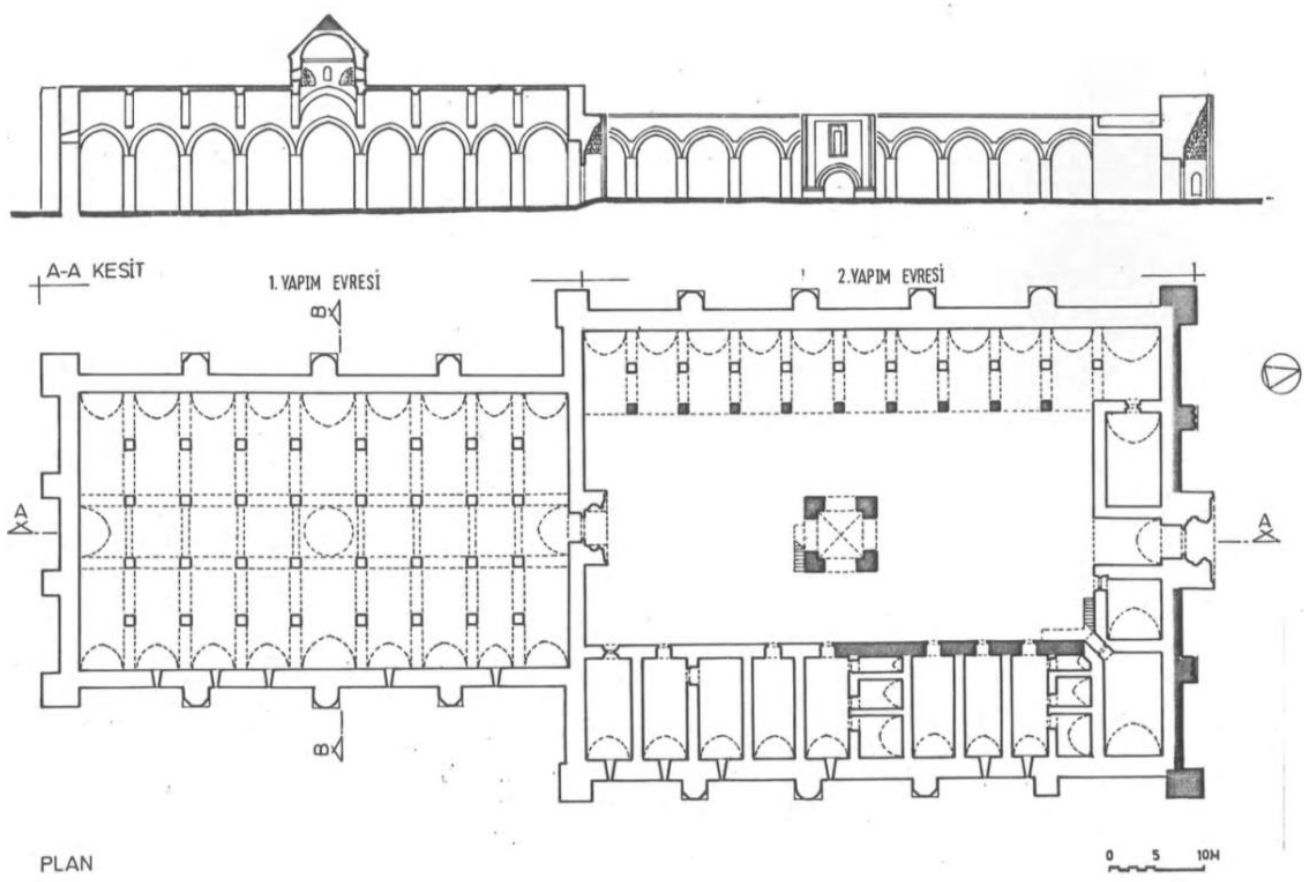

Figure 20. Aksaray Sultankhan Plan and Section

Source: Binan, C., (1990). 13. Yüzyıl Anadolu Kervansarayları Koruma Ölçütleri üzerine Bir Araştırma, Doktora Tezi, İTÜ Fen Bilimleri Enstitüsü, İstanbul, 203).

Courtyard planned caravanserais

This typology, which is generally seen in the Southeastern Anatolia Region, is similar to the plan of the caravanserais of the Arabian geography. The spaces around the courtyard form an axially symmetrical plan. The examples of this 
structure are more limited than the other caravanserais and khans in Anatolia. ${ }^{49}$ An example is Evdir Han, which has this typology reaching daily in Anatolia (see Figure 21).

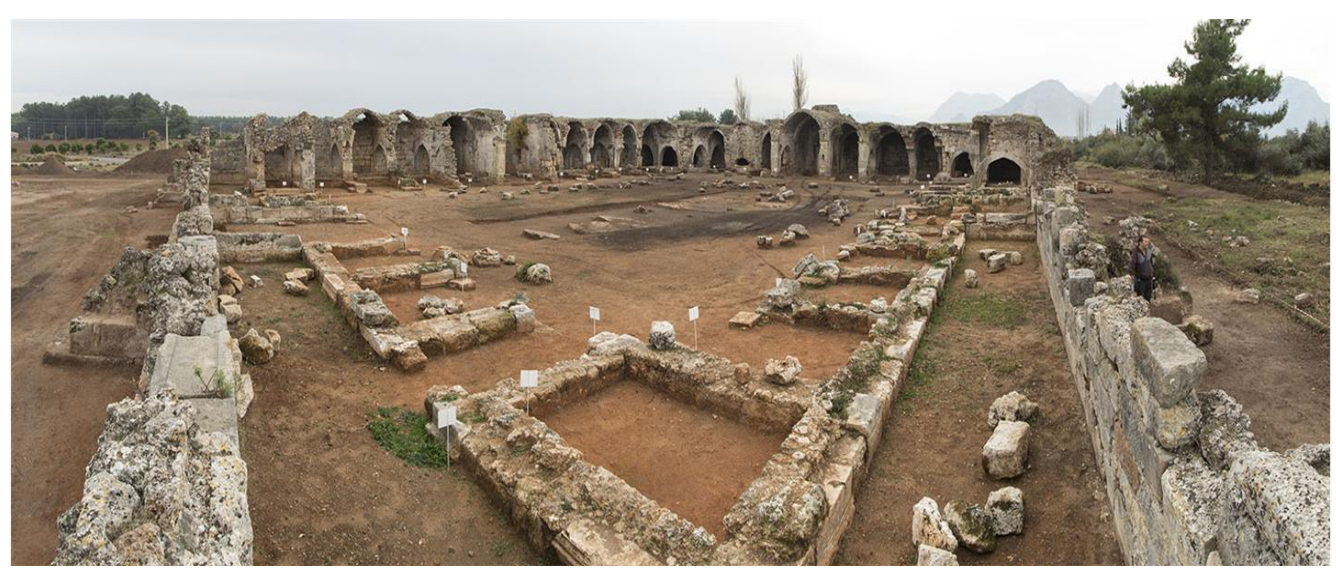

Figure 21. Evdir Khan(Antalya) Courtyard and Ruins

Source: http://www.dosemealti.bel.tr/tr/m/tarihi-yerler/evdir-han.html.

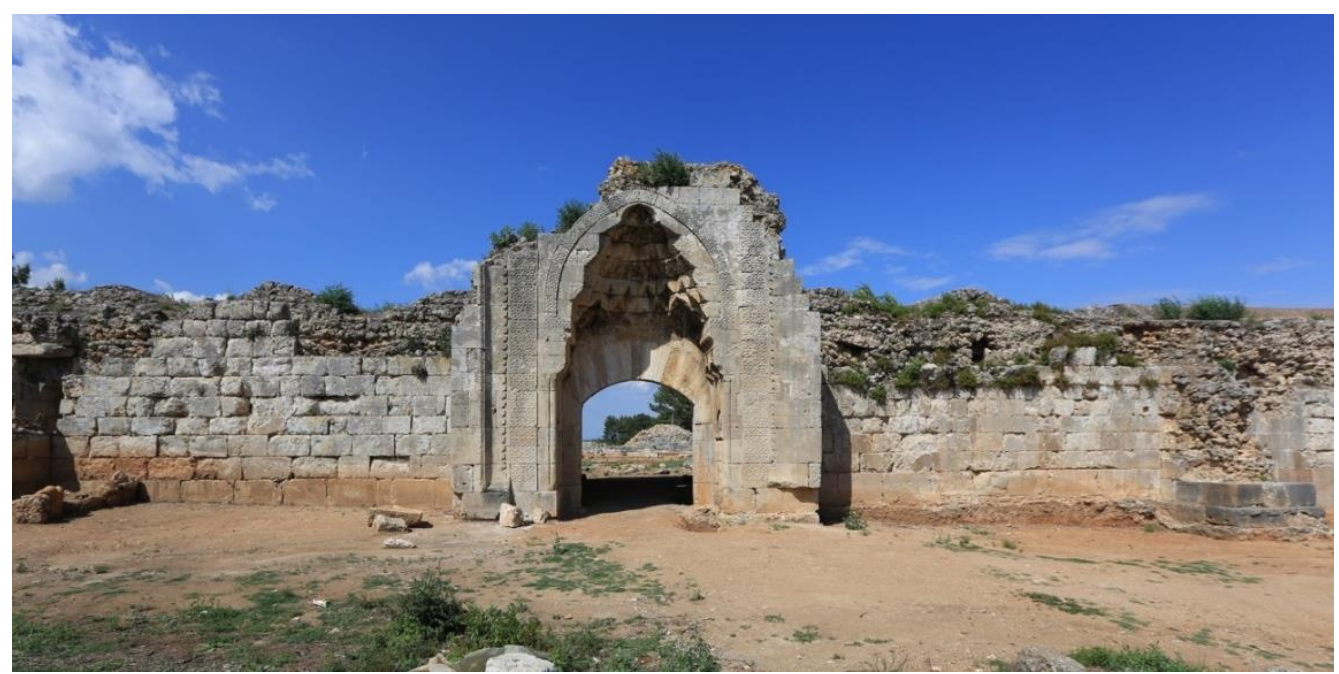

Figure 22. Evdir Khan Portal

Source: https://www.semerkanddanbosnaya.com/portfolio/evdir-han/.

It is the first stop of the caravans from Antalya on Burdur road in Antalya. The rectangle in the middle consists of spaces shaped around a large courtyard. There is an iwan (eyvan) at the midpoint of each edge. The portal on the south facade was opened.

The most monumental structural element of the building is the portal (see Figure 28). Although the portal is largely devastated, the stone dressing and muqarnases on it have been reached to date.

49. Binan, 13. Yüzyll Anadolu Kervansarayları Koruma Ölçütleri üzerine Bir Araştırma, 1990, 248. 


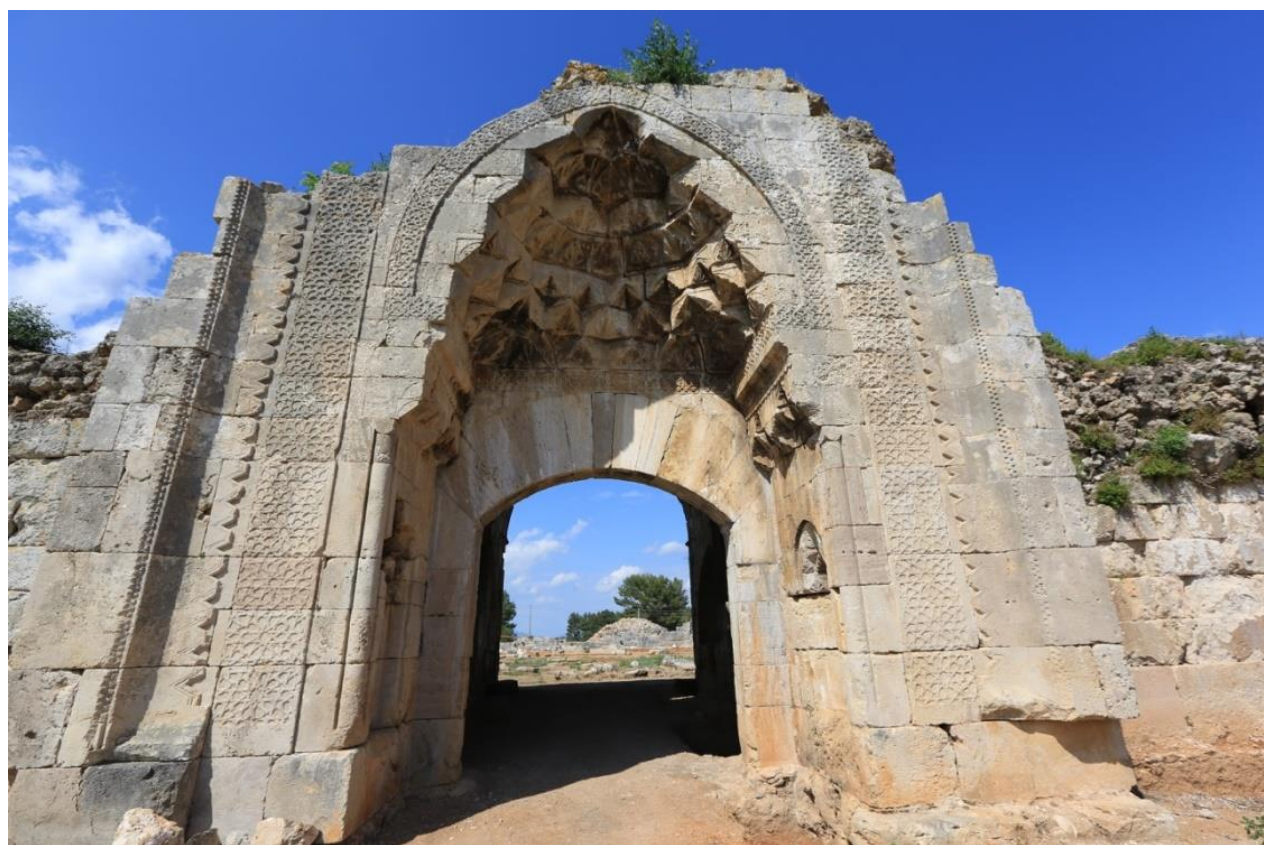

Figure 23. Evdir Khan Portal

Source: https://www.semerkanddanbosnaya.com/portfolio/evdir-han/.

A large part of the porticos that surround the courtyard from all four sides has been ruined. The roofs of the eastern and southern porticoes reached up to date. Only the body walls of the porticoes in the other parts remain. ${ }^{50}$ (See Figure 24).

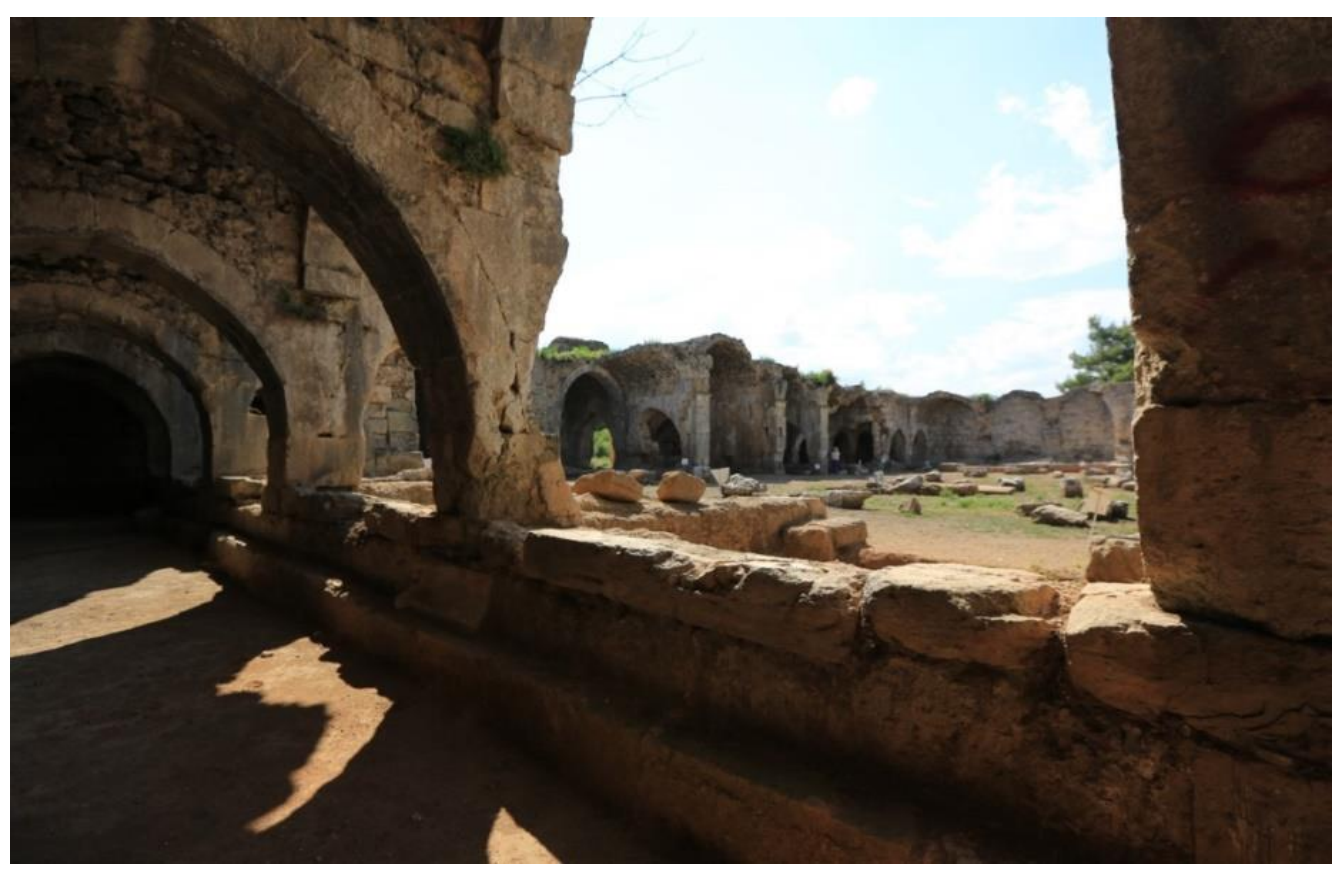

Figure 24. Evdir Khan Indoor

Source: https://www.semerkanddanbosnaya.com/portfolio/evdir-han/.

50. Acun, Anadolu Selçuklu Kervansarayları, 2007, 423. 


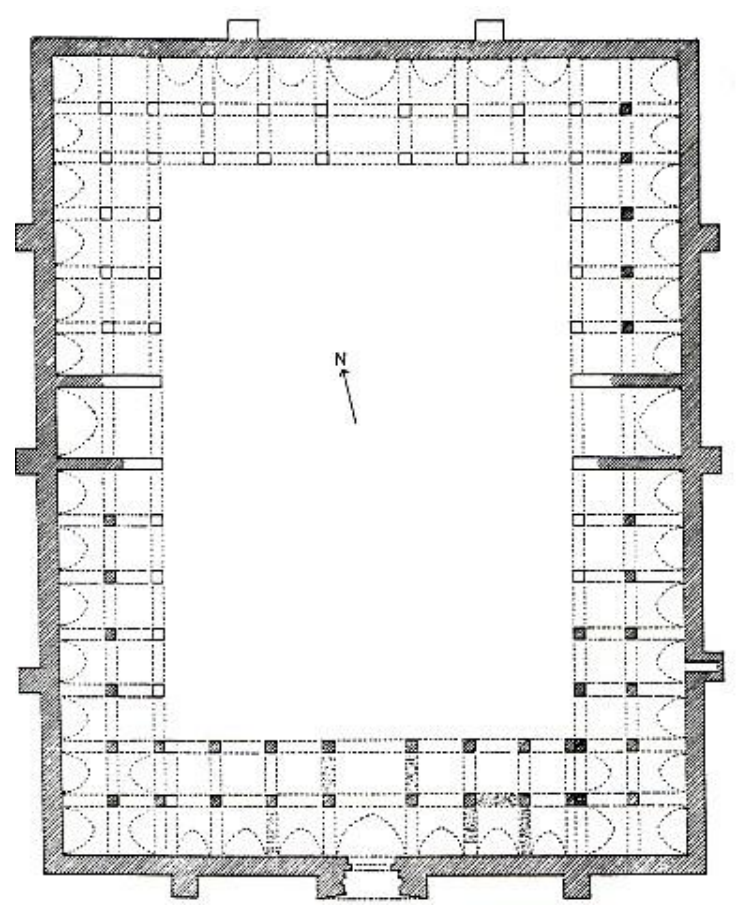

Figure 25. Evdir Khan Plan

Source: http://www.turkishhan.org/evdir.html.

Concentric planned caravanserais

These constructions, which are limited in Anatolia, are the most advanced type of caravanserai plan typology. The fact that it has been used in different geographies may be a sign that it is not affected by climatic differences. The places are different according to the functions. Most of the places are reserved for caravans. The room, the layout of the iwan, and the rooms are different day and night. There are barns on the outermost layer of the structure. ${ }^{51}$ Concentric planned caravanserais create an original typology with plan features and space constructions. $^{52}$

In Anatolia, for example, Alara Khan, Eshab-1 Kehf Khan and Mama Hatun Caravanserai can be given as examples of concentric planned khans and caravanserais. Erdmann in studies on these structures, drew attention to the similarities between the Alara Khan and Eshab1-1 Kehf Khan. Ünal also pointed out the similarities between Mama Hatun Caravanserai and Eshab-i Kehf Khan.

Alara Khan which is one of the caravanserai having concentric planned typology is in the north-south line of the Seljuks caravan roads. According to the stone tablet, the year of construction is 1231. It was built by Sultan Alaaddin Keykubat period.

The portal is between the two struts on the north side. There is a stone tablet

51. Binan, 13. Yüzyll Anadolu Kervansarayları Koruma Ölçütleri üzerine Bir Araştırma, 1990, 249.

52. A. Yavuz Tükel, “Anadolu'da Eşokdalı Selçuklu Hanları,” ODTÜ Mimarlık Dergisi II/2 (1976), 187. 
of two parts on the portal. ${ }^{53}$

In the planning scheme; it is understood that the central parts of the structure serve the travelers and caravans. In the same direction as the entrance gate of the khan, it is entered through a flat arched portal. In this section, the spaces are arranged around a central corridor. Places formed line in the form of an arm, an iwan. There are four rooms and three iwans on each side. It is understood from this plan scheme that spaces are reserved for day and night use. The rooms are used for iwans day to night. This reveals the unique side of the caravanserai. It was demolished in the middle of the hallway on the top cover. Other spaces are covered with a pointed vault. ${ }^{54}$ (See Figure 26).

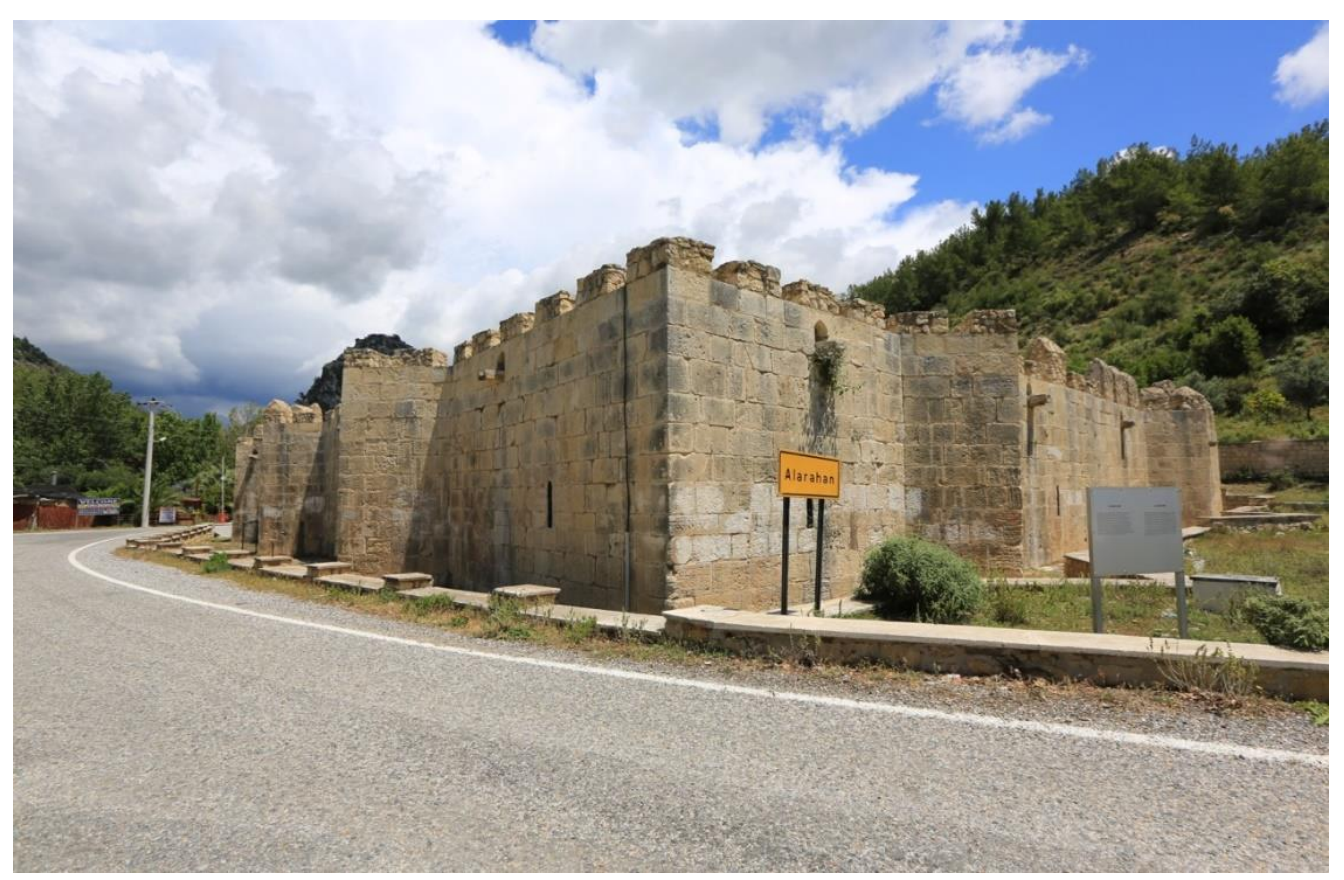

Figure 26. Alara Khan(Antalya) General View

Source: https://www.semerkanddanbosnaya.com/portfolio/alara-han/.

There are a number of service spaces on the outside of the khanplan in the north, in front of the central part and behind the outer wall in the north of the khan. The organization of these places is made open yard where the portal of the khann is opened. The entrance and exit gate of the khan, the middle section and the corridors opening in the service spaces open this courtyard (see Figure 26).

The long side of the northern corridor where the courtyard is opened is limited to the middle part (the part reserved for the accommodation of the passengers) in the south and the fountain, the iwan and the two rooms in the north. The two corridors are opened to the galleries. From there, service areas are provided. ${ }^{55}$

Surrounding the central portion is located on the south, west and the east

53. Binan, 13. Yüzyll Anadolu Kervansarayları Koruma Ölçütleri üzerine Bir Araştırma, $1990,42$.

54. Yavuz Tükel, “Anadolu'da Eşokdalı Selçuklu Hanları,” 1976, 189.

55. Ibid. 
direction gallery. The outermost row of these galleries forming two rows in the interior forms the barns. In the barns the animals are connected and fed. The interior galleries have created spaces for the khan staff and the residents. In addition to this, the caravan's cargoes are stored in the galleries inside (see Figures 27-28).

In order to separate the inner gallery space from the barn, 'seki' was created. Interior gallery spaces are about 70-80 cm higher than stables. It can be said that the residents observe their belongings and their animals in the spaces opened to the galleries from the places in the middle part. The building receives light from the narrow, long tilted windows that open out on the outer walls and from spaces in vaults. Candils on the consoles in arches are provided with the lighting at the night. $^{56}$

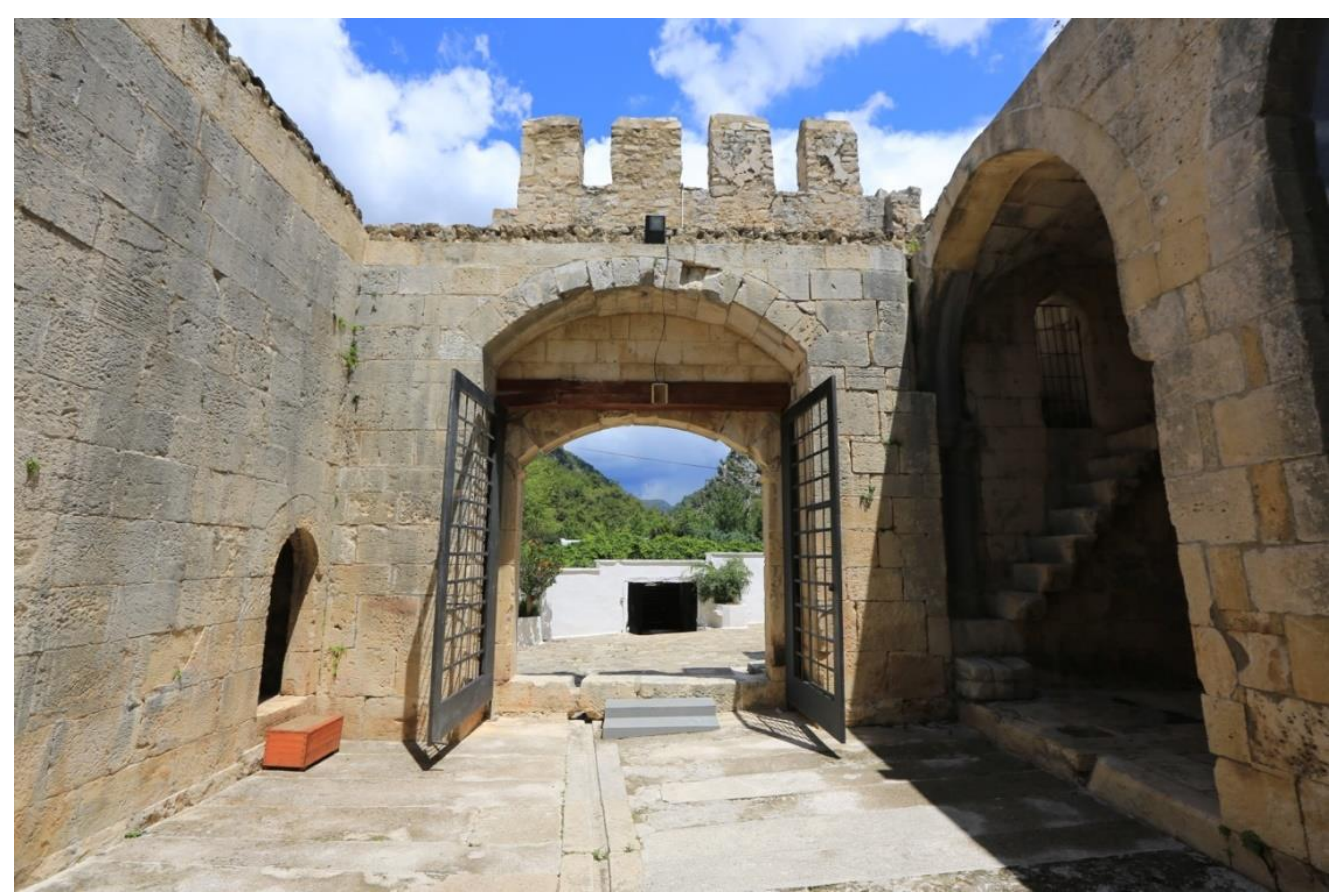

Figure 27. Alara Khan Indoor and Portal

Source: https-//www.semerkanddanbosnaya.com/portfolio/alara-han/3.jpg.

The top cover of the bark is the soil roof. The roof of the upper cover did not prevent water from getting in the roof. So, melted the porous limestone used on the walls of structure. ${ }^{57}$

56. Ibid.

57. Binan, 13. Yüzyll Anadolu Kervansarayları Koruma Ölçütleri üzerine Bir Araştırma, 1990, 43. 


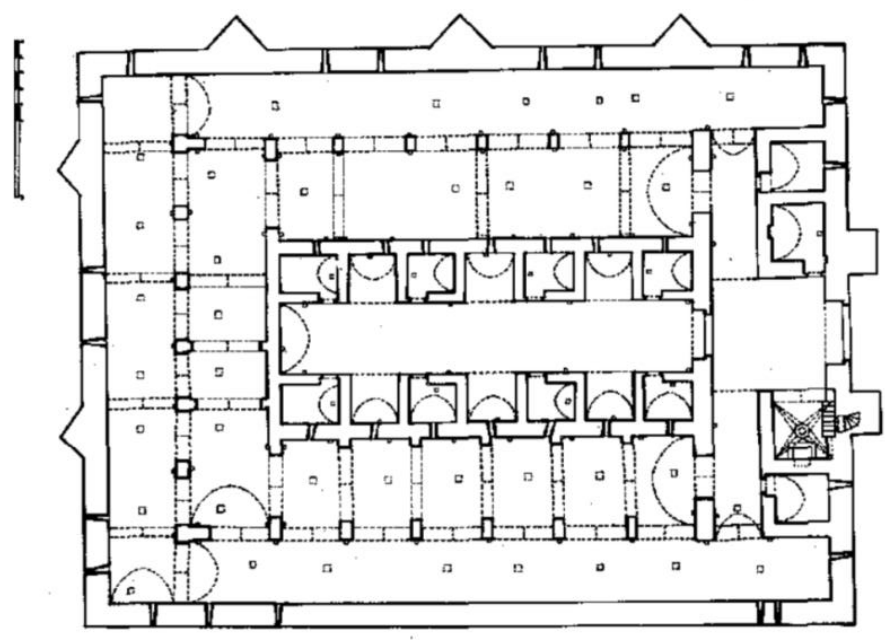

$\triangleright$

Figure 28. Alara Khan Plan

Source: Binan, C., (1990). 13. Yüzyıl Anadolu Kervansarayları Koruma Ölçütleri üzerine Bir Araştırma, Doktora Tezi, İTÜ Fen Bilimleri Enstitüsü, İstanbul, 203).

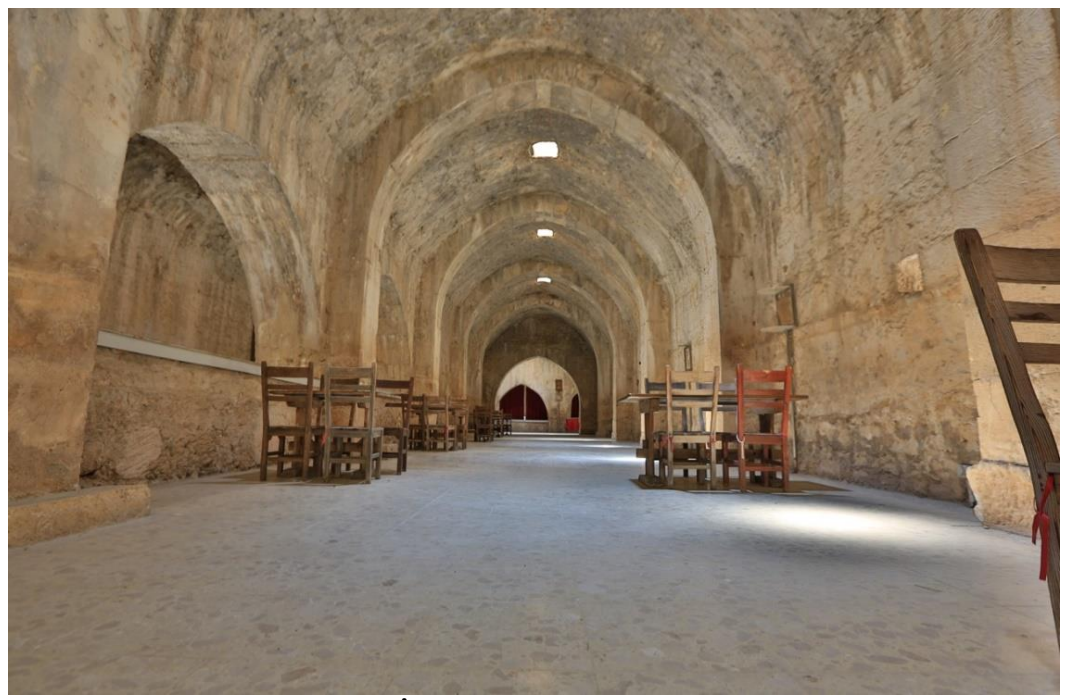

Figure 29. Alara Khan Indoor

Source: https://www.semerkanddanbosnaya.com/portfolio/alara-han/.

We can say that, compared to other types of caravanserai typology, the concentric planned caravanserai which has not much samples outside of Anatolia has a more advanced plan design. These caravanserais, which are among the most important examples of Anatolian Seljuk architecture, vary in size depending on their location and user. ${ }^{58}$

58. Yavuz Tükel, “Anadolu’da Eşokdalı Selçuklu Hanları,” 1976, 199. 
In addition to the foundation caravanserais in Anatolia, there are also smallscale caravanserais built by people to meet needs for caravans. Located on Kayseri-Aksaray road, Sarı Khan can be an example of this construction.

There are two portals with a rectangular planned courtyard and a closed structure. The courtyard was added later as seen in the other examples. The exterior walls of the building have undergone major repairs and completion since they have been damaged to a great extent (Figures 30-32).

To the north of the portal, on the eastern of the courtyard, there is a hanging stone stairs, rising by separating into two opposite arms. The stairway leading to the north leads to the roof of the khan, the other to the entrance to the masjid.

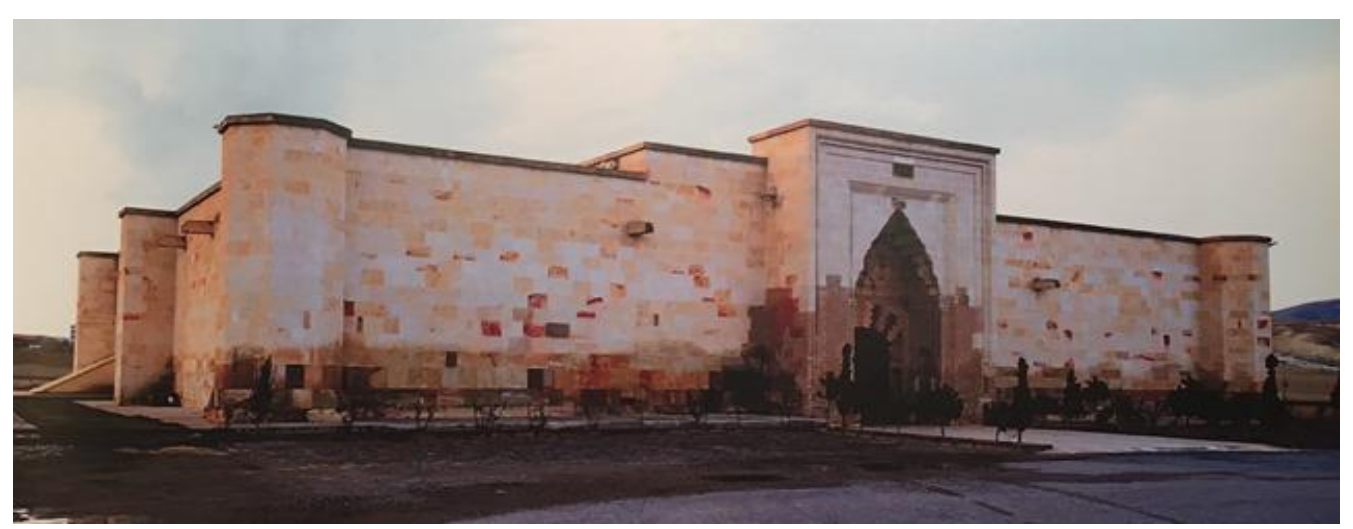

Figure 30. Sarı Khan (Nevşehir) General View

Source: http://www.turkishhan.org/sari.htm.

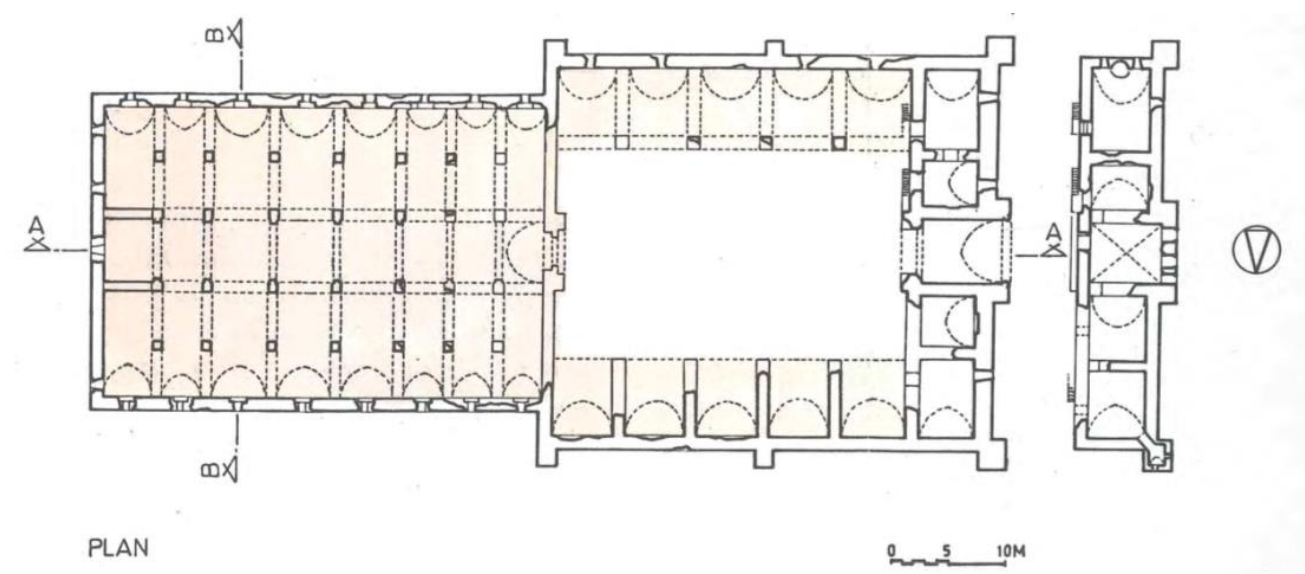

Figure 31. Sarl Khan Plan

Source: Binan, C., (1990). 13. Yüzyıl Anadolu Kervansarayları Koruma Ölçütleri üzerine Bir Araştırma, Doktora Tezi, İTÜ Fen Bilimleri Enstitüsü, İstanbul, 189. 


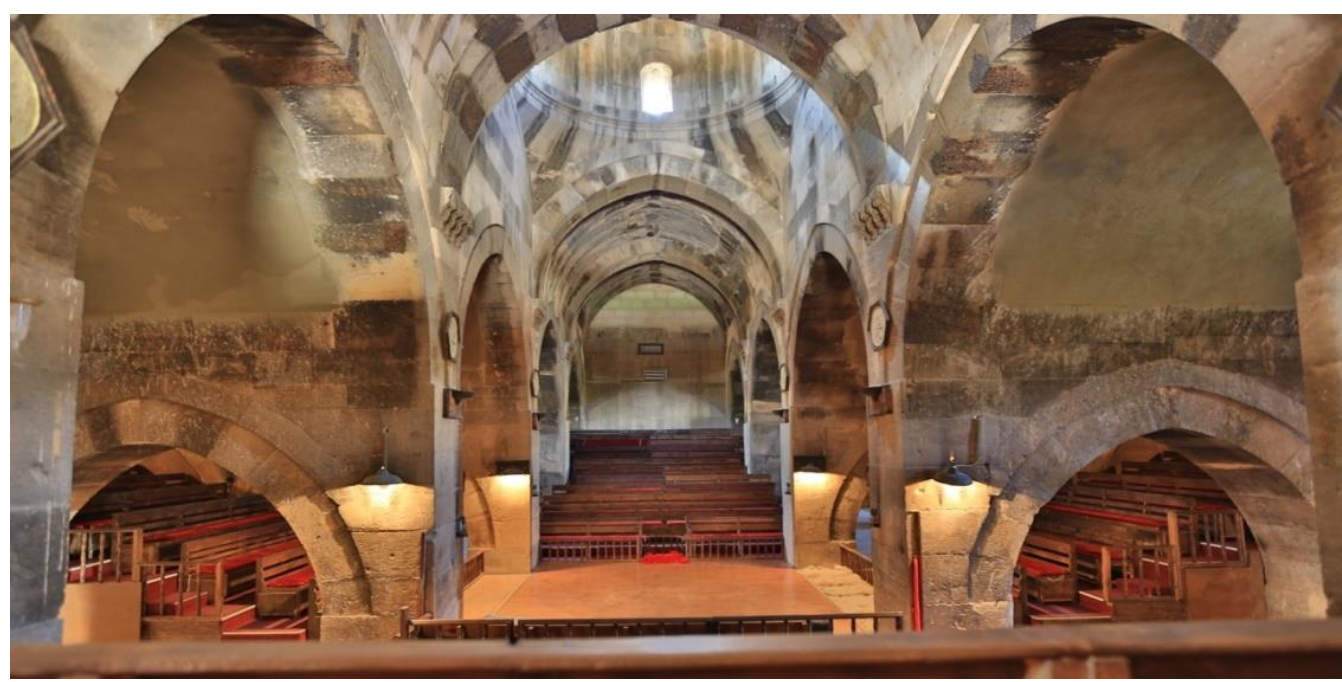

Figure 32. Sarl Khan Closed Space

Source: https://www.semerkanddanbosnaya.com/portfolio/sarihan/.

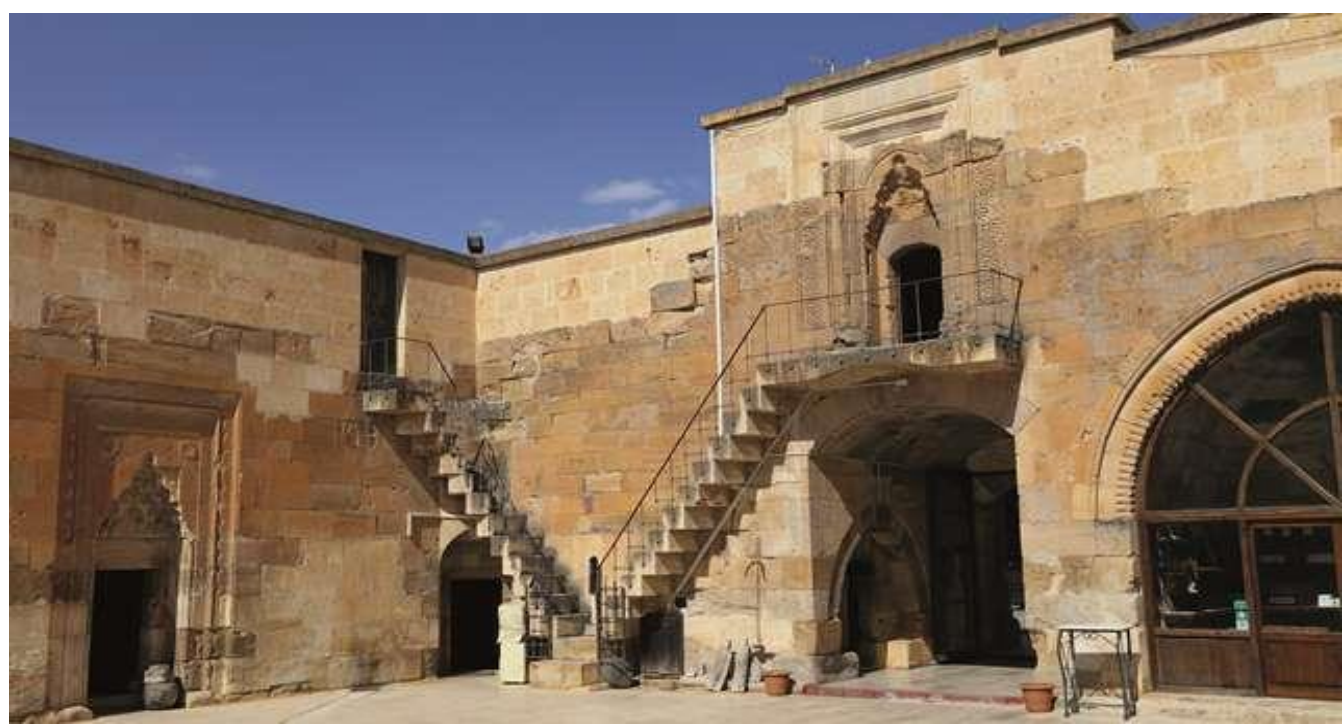

Figure 33. Sarl Khan Masjit

Source: https://www.semerkanddanbosnaya.com/portfolio/sarihan/.

Portals

The facades of the caravanserais are quite simple. Facades given a castle view are mostly built with cut stone or rubble stone. The most glamorous elements of the constructions are the 'portals' which are the only connection point outside. The portals give a dynamic appearance to the saphenous lining. It has supported the monumental appearance of the building. It is usually exceed the height of the props for building and construction in the middle. It protrudes over the facade surface. As a result, the depth of the niche opened on the facade has increased. This created a more unobtrusive image. The vegetation and geometric designs of 
the Seljuk stone artwork are carved into the stones with great skill. ${ }^{59}$ (See Figures 34-36).

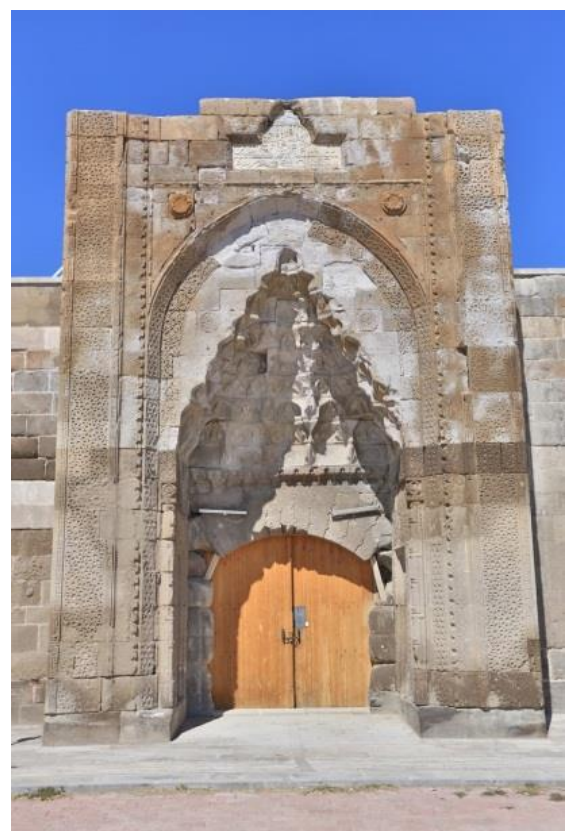

Figure 34. Karatay Khan (Kayseri) Facade and Portal

Source: https://www.semerkanddanbosnaya.com/portfolio/karatay-han/.

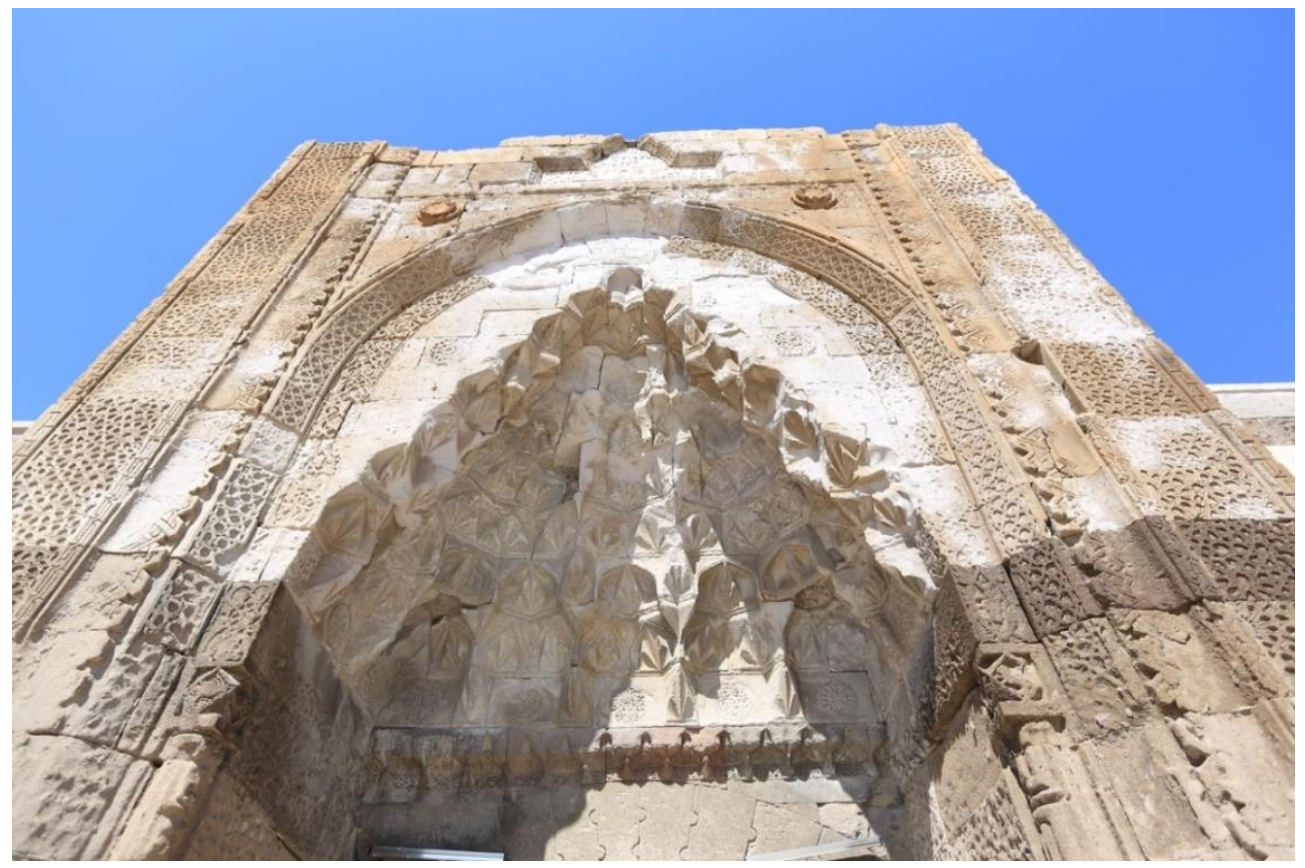

Figure 35. Karatay Khan Portal Muqarnas Detail and Ornamentation Source: https://www.semerkanddanbosnaya.com/portfolio/karatay-han/.

59. Ç. Erberk, "Anadolu Selçuklu Dönemi Taçkapıları Süsleme Şeritlerinde Tenziyat," Pamukkale Üniversitesi Illahiyat Fakültesi Dergisi, Denizli 3, no. 5 (2016): 115. 


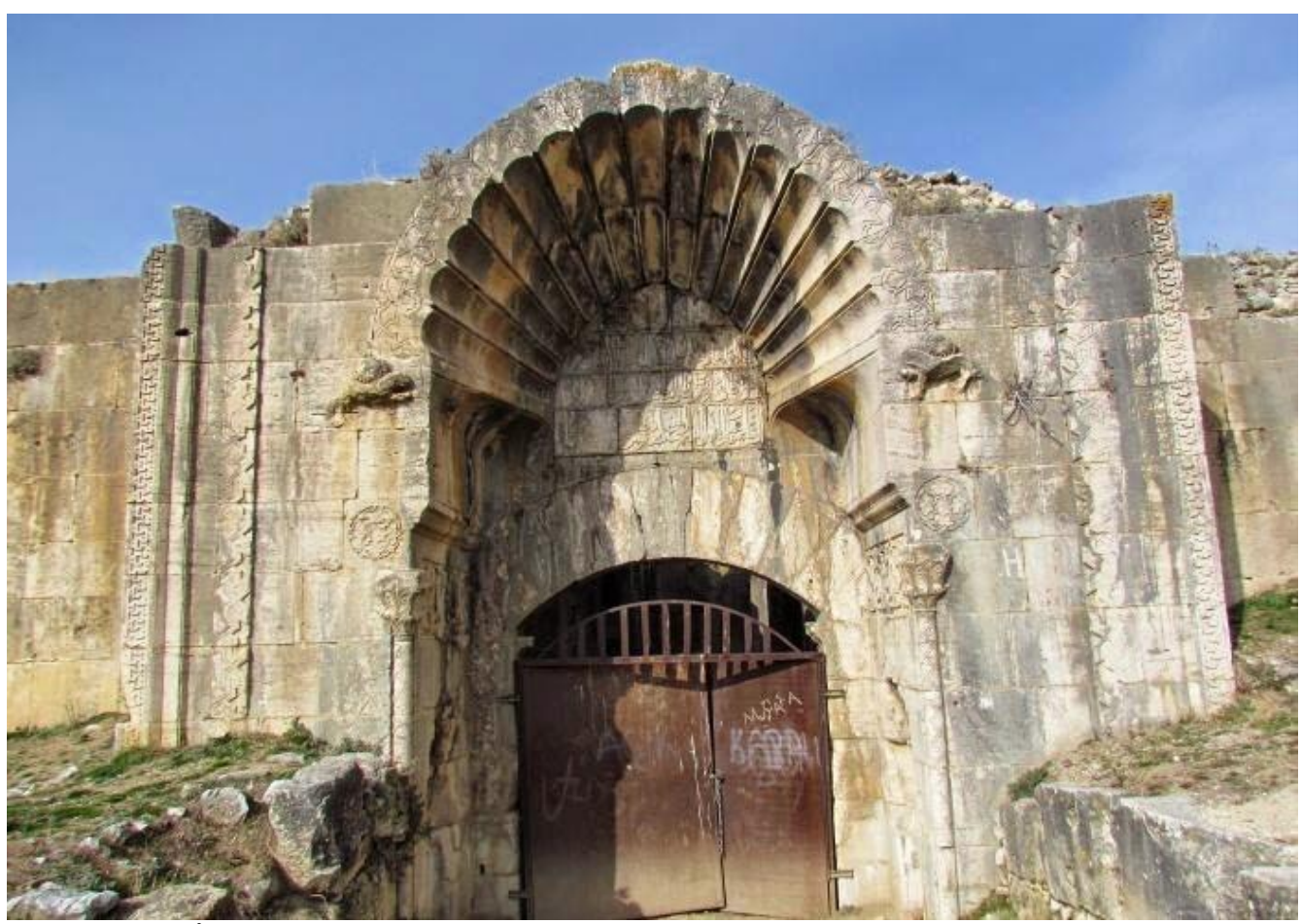

Figure 36. Incir Khan (Burdur) Portal

Source: https://www.toroslardayasam.com/2014/10/incir-han-burdur-ilibucak-ilcesi-snrlar.html.

Apart from the portals, other architectural elements attracting attention on the facades of the caravanserai have also become struts. They are not as magnificent and embroidered as portals. It is mostly used to strengthen facades and walls from a static point of view. In addition to the strengthening function, it gave a stable, strong expression to the structure in simple and geometric form. ${ }^{60}$

The struts are usually placed symmetrically on the facades. In some large caravanserais and sultankhans, the struts were placed in the facades. In the facades, generally triangular, rectangular, half octagonal, star and sliced geometric shapes are used (see Figures 37-38). These geometric shapes were used in $3 / 4$ of the cupboards at the corners. ${ }^{61}$

60. D. Kuban, Selçuklu Çağında Anadolu Sanatı (İstanbul: Yapı Kredi Yayınları, 2002), 249.

61. Tükel Yavuz, Anadolu Selçuklu Kervansaraylarında Mekân-İslev İlişsisi İçinde Savunma ve Barınma. IX. (Ankara: Vakıf Haftası Kitabı, 1992), 255. 


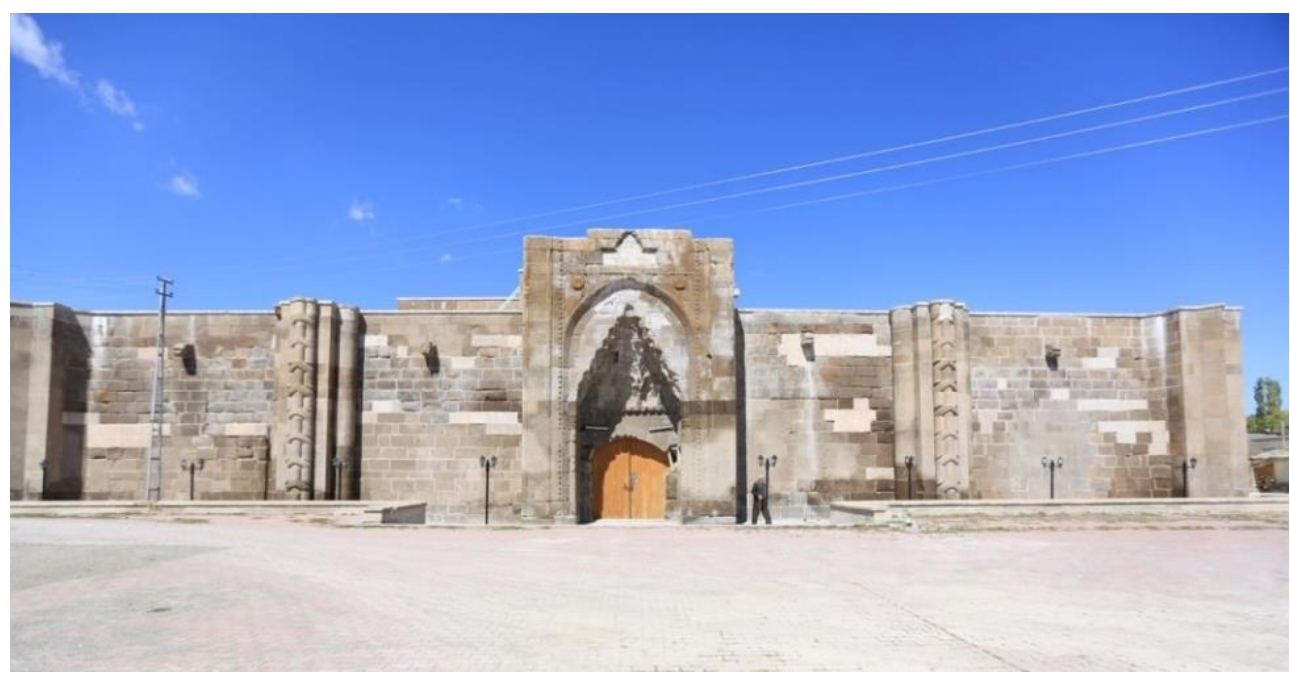

Figure 37. Karatay Khan (Kayseri) Facade and Portal, Struts

Source: https://www.semerkanddanbosnaya.com/portfolio/karatay-han/.

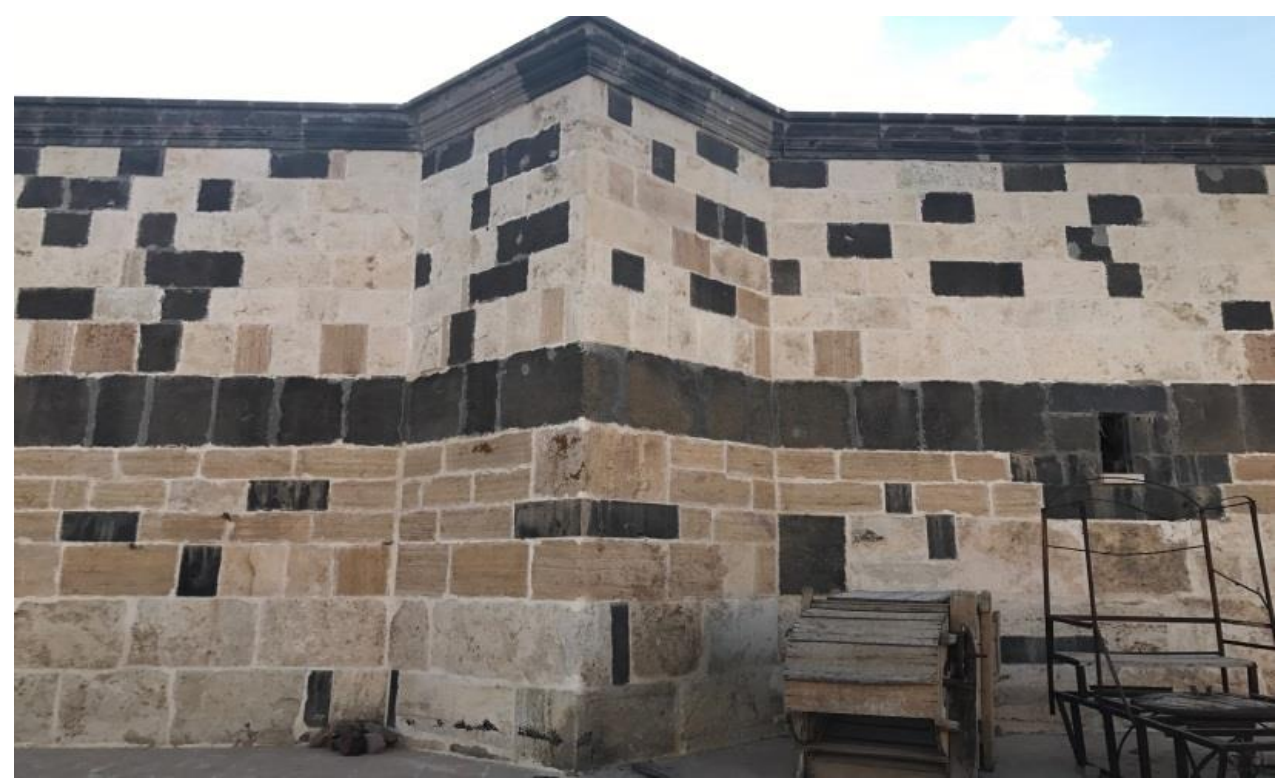

Figure 38. Alacahan(Sivas) Facade ve Triangular Strut

Source: Eylül, 2018.

\section{Kiosk Masjids}

There are storeage, warehouses, baths, mosques, etc. in the caravanserais. Masjids in the caravanserais of Anatolian Seljuks became one of the most important places. In the first Turkish states and ribats, there are masjids along with service spaces. For masjids there is no specific place in the planning of the plan. It is usually positioned in the direction of the entrance gate. Some examples include masjids located on the second floor. In this construction, Sousse Ribat, Tunisia can be an example.

There are various plan typologies in Anatolian Seljuk caravanserais. For this reason, no specific place for masjids has been shown. As in the first Turkish states, 
there are examples of entrance. In some cases, mosques are found adjacent to closed spaces. An example of this is Şarapsa Khan. ${ }^{62}$

Apart from these examples, there are examples of the masjids located in the middle of the courtyard. These masjids which are unique to Anatolian Seljuk caravanserai are called 'kiosk masjid'. Generally, stands in the middle of the courtyard, raised on four square piers joined by pointed arches (see Figures 39-40). There are also polygonal examples of these mosques in the Ottoman Empire which are also found in city khans.

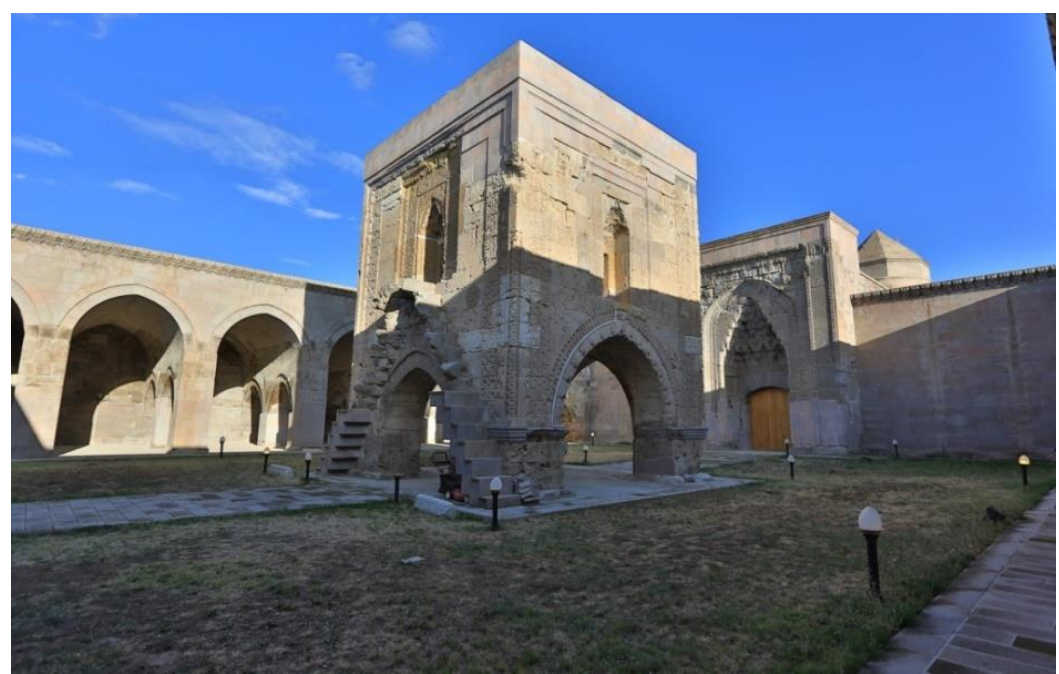

Figure 39. A $\breve{g z l k a r a h a n(A k s a r a y) ~ K i o s k ~ M a s j i d ~}$

Source: https://iyikivariz.com/2018/04/17/kapadokya-gezilecek-yerler/kapadokya-gezilecek-yerlerag\%CC\%86zikarahan/.

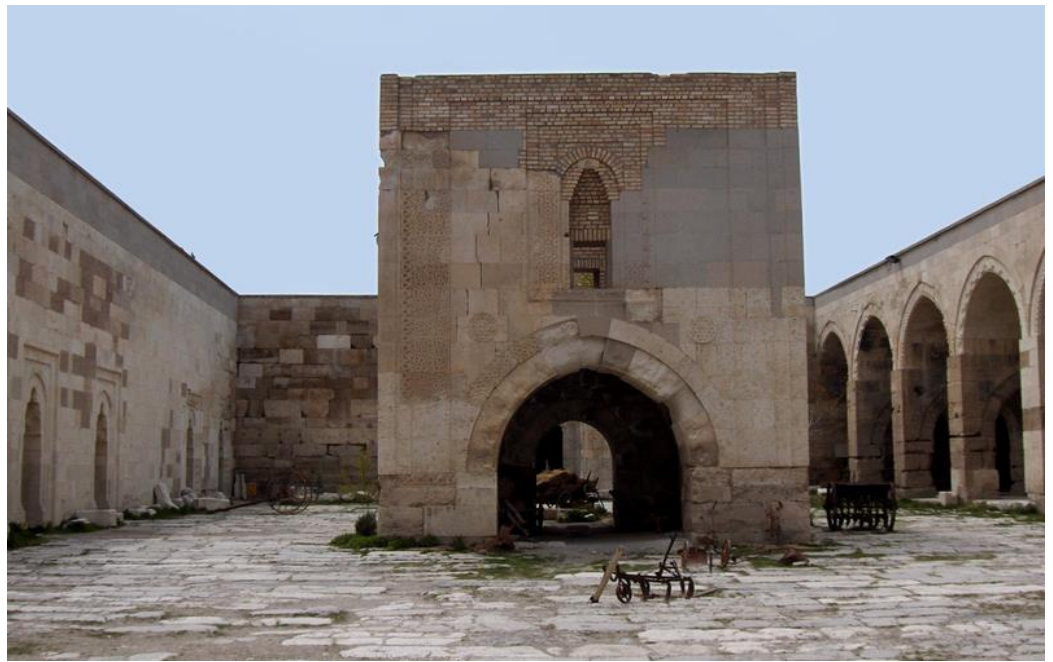

Figure 40. Sultankhan (Aksaray) Kiosk Masjid

Source: https://commons.wikimedia.org/wiki/File:Turkey.Aksaray004.png.

62. A. Denknalbant, Anadolu Selçuklu Kervansaray Mescitleri. Yüksek Lisans Tezi. (İstanbul: Sosyal Bilimler Enstitüsü, İstanbul Teknik Üniversitesi, 2004), 23. 


\section{Conclusions}

The ongoing trade concept with the existence of mankind has always been an economic and administrative power for the states. In history, great civilizations, states used trade to build political authority and strengthen economies. They needed a transportation system to make trade more efficient and to go to more regions. For this reason, great civilizations gave great importance to the construction and preservation of roads. Cultural exchanges have been made besides commercial shopping thanks to the links between countries and civilizations.

With the development of trade, goods and services have crossed the borders of the states. Long journeys have been made. On these journeys for months, accommodation and accommodation for travelers and caravans were needed.

When we look at the chronologically accommodation, we can say that it has a history that dates back to the before Christ. From the Assyrians, who have strong trade ties, the concept of trade has developed as much as every day. However, in order to meet the needs of passengers it was built on the road. During the Roman, Byzantine eras, constructions were built with a purpose of accommodation within a short distance on the roads in Anatolia and other geographical areas. The ribats that saw the first examples of Islam in the emerging geographical areas are buildings made with defense purposes. They have stayed in the country with the development of the borders and have provided accommodation services. These constructions which are quite simple are shaped according to their climate characteristics. Because the air temperature is generally high, it is composed of a large courtyard and portico units that revolve around it. In the Seljuks, who had seized trade in Anatolia since the $11^{\text {th }}$ century, the Ribat left their place in caravanserais.

The Seljuks extended their territory in the $10^{\text {th }}$ and $11^{\text {th }}$ centuries and gradually took control of Anatolia. The Seljuks gave importance to the commercial. Many caravanserais were constructed on the Anatolian roads, especially on the roads connecting important cities such as Konya, Sivas, Kayseri and Malatya.

We can say that Anatolian Seljuk caravanserais, which developed over time, is an original architectural style. Unlike the ribats, the plan of the caravanserais which consist of closed spaces and courtyard has developed according to economic conditions. Considering the cold winter months in Anatolia, the closed section was first built to meet the caravan's security and security needs. Then the courts were added with the improvement of the conditions, the increase of the economic level and the expansion of the requirement list. This typology comes across Anatolia, especially in the construction of Seljuk caravanserais (see Figure 41). 


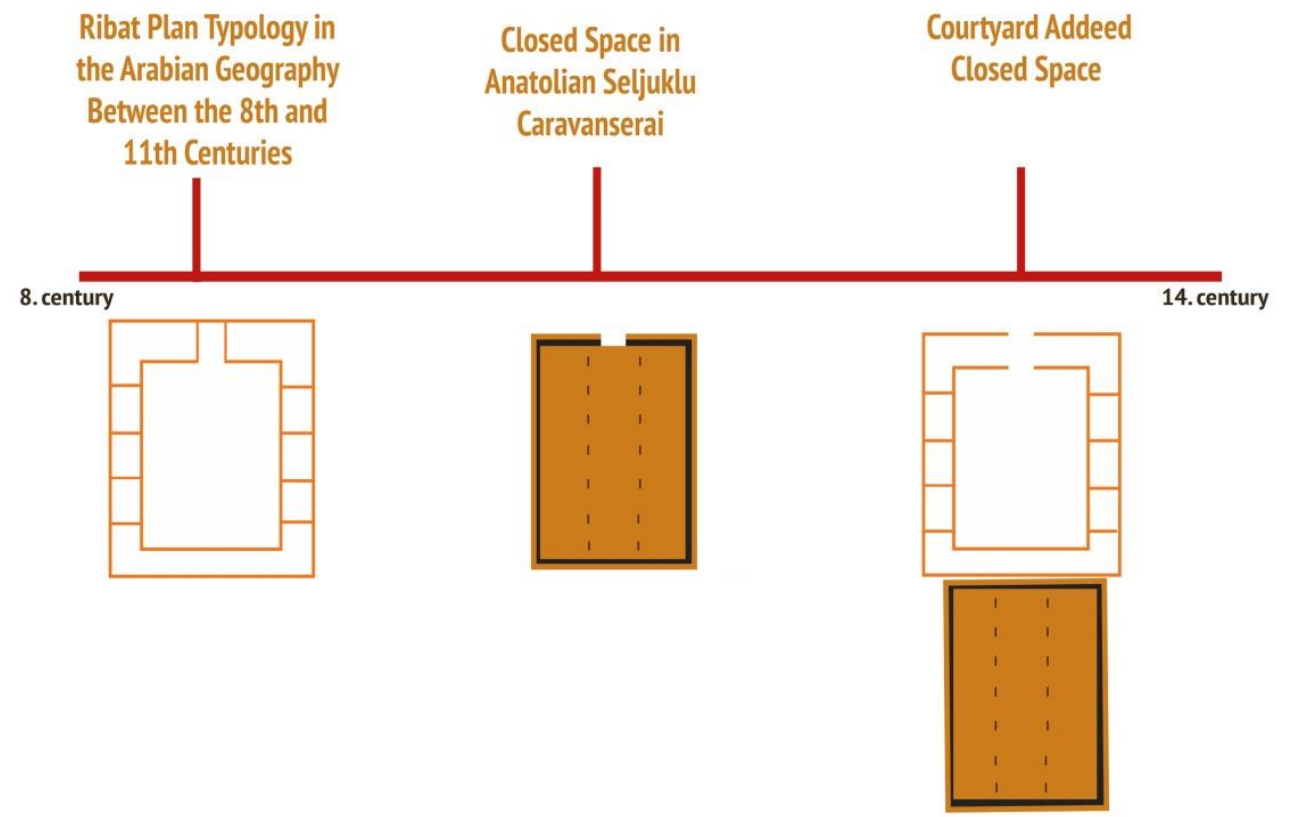

Figure 41. Schematic Diagram of Open and Closed Use in Ribat and Anatolian Seljuk Caravanserais

Source: Darendeli, 2018.

Another plan typology seen in the Anatolian Seljuks is the 'concentric planned khans'; it is the most developed caravanserai species. Other civilizations in BC, accommodation structures with various typologies in Roman, Byzantine and Arabian geography; in Anatolia, the needs have changed considerably over time.

The caravanserais, which were used effectively during the Seljuk period, later lost their importance to the caravan roads and left their place in the inner city khans. Today, with the change of roads, it has been difficult to function in the caravanserais in the countryside. Today, khans in the city are given accommodation and commercial functions.

\section{Bibliography}

Acun H. Anadolu Selçuklu Kervansarayları. [Anatolian Seljuk Caravanserais.] Ankara: T.C. Kültür Bakanlığı Yayınları, 2007.

Atasoy, F. Yükselen İekyolu 3. [Volume 3 of the Rising Silk Road'Cilt.] Ankara: Türk Yurdu Yayınları, 2016.

Baş, A. Beylikler Dönemi Hanları. [Khans of the Principalities Period.] SÜ, SBE, 1989.

Binan, C. 13. Yüzyll Anadolu Kervansarayları Koruma Ölçütleri üzerine Bir Araştırma. [A Research on the Criteria of Conservation of Anatolian Caravanserai in the $13^{\text {th }}$ Century.] Doktora Tezi. İstanbul: İTÜ Fen Bilimleri Enstitüsü, 1990.

Çetin, E. "Franz Taeschner'in Muhtelif Devirlerde Anadolu'nun Yolları Ve Cihan Münakalatına Nazaran Vaziyeti İSsimli Eseri ÜzeriNe Notlar." [Notes on Franz Taeschner's book titled The Paths of Anatolia in Various Periods and their Controversy.] Tarih Okulu Dergisi 17 (2014).

Denknalbant, A. Anadolu Selçuklu Kervansaray Mescitleri. [Anatolian Seljuk Caravanserai Masjids.] Yüksek Lisans Tezi. İstanbul: Sosyal Bilimler Enstitüsü, İstanbul Teknik Üniversitesi, 2004. 
Erberk, Ç. "Anadolu Selçuklu Dönemi Taçkapıları Süsleme Şeritlerinde Tenziyat." [Decoration in Ornamental Ribbons of the Anatolian Seljuk Period Crown Gates.] Pamukkale Üniversitesi İlahiyat Fakültesi Dergisi, Denizli 3, no. 5 (2016).

Eskikurt, A. "Ortaçağ Anadolu Ticaret Yolları." [Medieval Anatolian Trade Roads.] Sosyal Bilimler Enstitüsü Dergisi, Muğla (2014).

Karacan, S., E. Karacan and Y. Güngör. "Osmanlı'da Konaklama Hizmeti Veren Yapılardan Gebze Çoban Mustafa Paşa Kervansarayı.” [Gebze Çoban Mustafa Pasha Caravanserai, One of the Structures that Provide Accommodation in the Ottoman Empire.] III.Disiplinlerarast Turizm Araştırmaları Kongresi Bildiri Kitabl, III.Disiplinlerarası Turizm Araştırmaları Kongresi, 2014.

Karacan, E., S. Karacan and Y. Güngör. "Tarihsel Süreç İçinde Konaklama Merkezleri Han ve Kervansarayların Günümüzde İpek Yolu Projesine Dönüşümü.” [Transformation of Accommodation Centers, Inns and Caravansaries to the Silk Road Project in the Historical Process.] 5.Doğu Akdeniz Turizm Sempozyumu ve I. Uluslararası Doğu Akdeniz Turizm Sempozyumu, Nisan, Doğu Akdeniz Üniversitesi Turizm Fakültesi, KKTC, 2016.

Kuban, D. Selçuklu Çağında Anadolu Sanatı. [Anadolu Anatolian Art in the Seljuk Period.] İstanbul: Yapı Kredi Yayınları, 2002.

Osman T. "Selçuklu Kervansarayları.” [Seljuk Caravanserais.] TTK Belleten X/39 (1946): 471-496.

Sönmez, S. "Ortaçağ Türk ve İslam Dünyasında Kervansaraylar (Hanlar - Ribatlar.)" [Caravanserais in the Medieval Turkish and Islamic Worlds (Khans - Ribats.)] Kâzım Karabekir Eğitim Fakültesi Dergisi, Erzurum (2007).

Turan, O. "Selçuk Kervansarayları." [Caravanserais of Seljuks.] T.T.K. Belleten X/39 (1946).

Ünal, H. R. "Antalya-Korkuteli Kervan Yolu Üzerinde Bilinmeyen Üç Han.” [Three Unknown Inns on the Antalya-Korkuteli Caravan Road.] Sanat Tarihi Dergisi XIX/1 (2010).

Yavuz Tükel, A. "Anadolu'da Eşokdalı Selçuklu Hanları." [Concentric Planned Khans of Seljuks.] ODTÜ Mimarlık Dergisi II/2 (1976).

- Anadolu Selçuklu Kervansaraylarında Mekân-İşlev İlişkisi İçinde Savunma ve Bartnma. [Defense and Housing in the Relation of Space-Function in the Anatolian Seljuk Caravanserais.] IX. Ankara: Vakıf Haftası Kitabı, 1992. 



\title{
Costabili Palace and the Architecture "All'Antica" in Ferrara at the End of the XV Century
}

\author{
By Benedetta Caglioti ${ }^{*}$
}

\begin{abstract}
Costabili Palace, also known as Ludovico "il Moro" (Ludovico Sforza, Duke of Milan) Palace, is located in Ferrara on the ancient Ghiara road, occupying the corner that it forms with via Porta d'Amore, in the south-eastern area of the city. Attributed to the architect Biagio Rossetti (1447-1516) it represents, by size and formal wealth, begun but never completed, the most ambitious palace of the Renaissance in Ferrara. Commissioned by Count Antonio Costabili (14501527) at the end of the Fifteenth century, the construction was interrupted in 1503. Of four sides of its court only two were built in their rich and cultured architectural language, and only half of the main façade was sketched. Through the unpublished archival research carried out, crossed with the direct study of the building by surveying the relevant stylistic elements, helped by a proportional analysis and the reading of the stratigraphic masonry units, this doctoral research retraces the history of the construction. This work has clarified the role of the artists involved and their relationship with the strong personality of the client Antonio Costabili, ambassador in Milan of the Duke of Ferrara (Ercole I d'Este) from the year 1496 until the year 1499, one of the most representative intellectuals of his time thanks to a solid humanistic and artistic education. From a systematic study of an unfinished building site the precise design of the Costabili Palace will emerge as expression of a clear linguistic and lexical intention, called "all'antica", inspired to the Roman classical architecture. The proposed research is wondering about the real contribution that the architectural culture in Ferrara at the end of the Fifteenth century, highly represented by the Costabili Palace, offers to the broader context of the Renaissance courts.
\end{abstract}

\section{Introduction}

Palazzo Costabili is located in south-eastern Ferrara, along the historic Via della Ghiara, now Via XX Settembre. The palace marks the intersection with Via Porta d'Amore, in the oldest part of the city, known as the Polesine di Sant'Antonio. The area is part of the expansion commissioned by Duke Borso d'Este (1450-1471) to create a street marking the historic and straight passage of the Po River, from east to west (Figure 1).

The palace continues to occupy a marginal position with respect to the historic centre of Ferrara, despite its imposing mass and architectural beauty. Far from the city's important religious centre, marked by the Cathedral, its position at the edge of the medieval city is also distant from the addition (known as Erculean Addition) to the city realised by Duke Ercole I d'Este (1471-1505) at the end of the fifteenth century, while Palazzo Costabili was under construction.

*PhD Student, Sapienza University of Rome, Italy. 


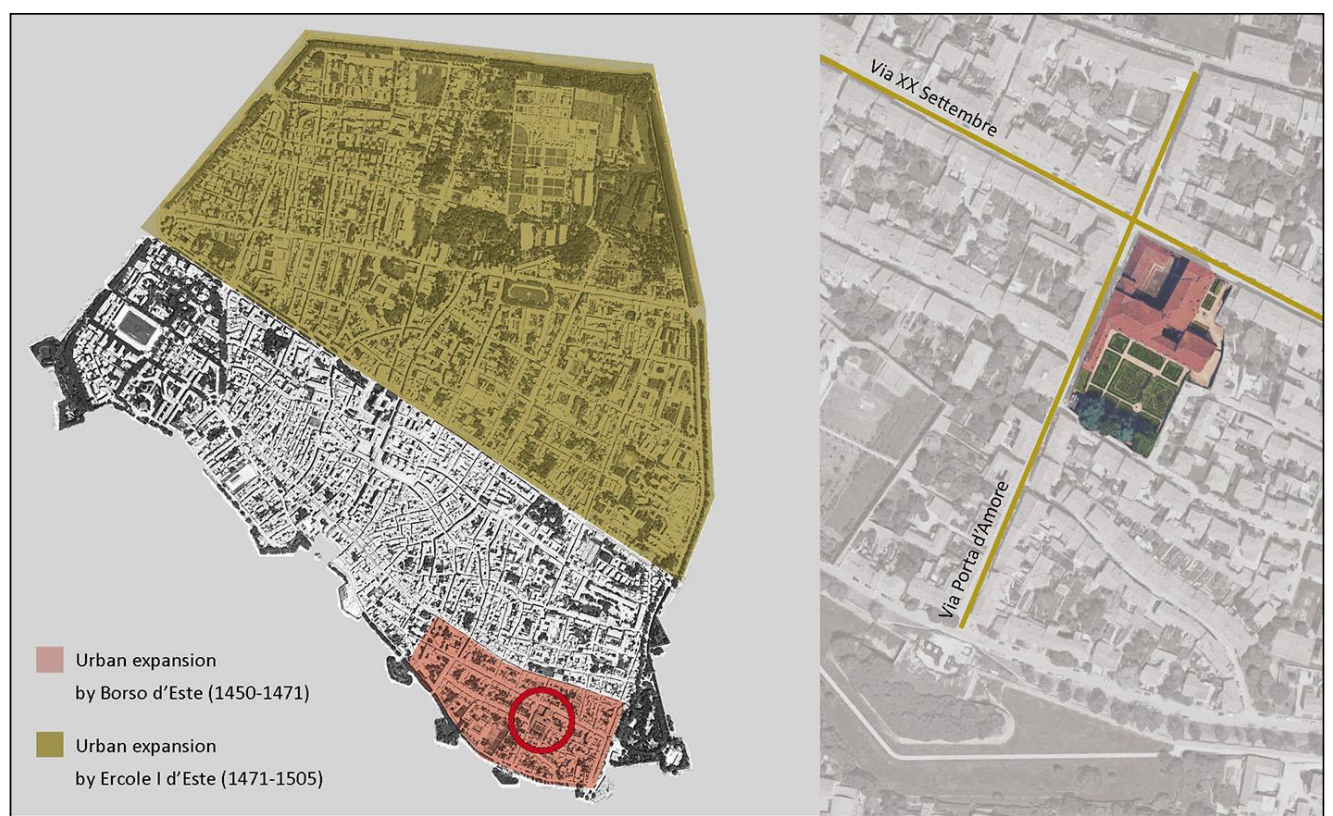

Figure 1. Identification of Costabili Palace (Red Circle) inside the City of Ferrara and the Great Urban Expansions of the City during the XV Century Source: Elaboration of Satellite Images by the Author.

In Figures 2-4 the surveys and photomaps, taken by the author, are reported in order to understand the architecture of Palazzo Costabili.

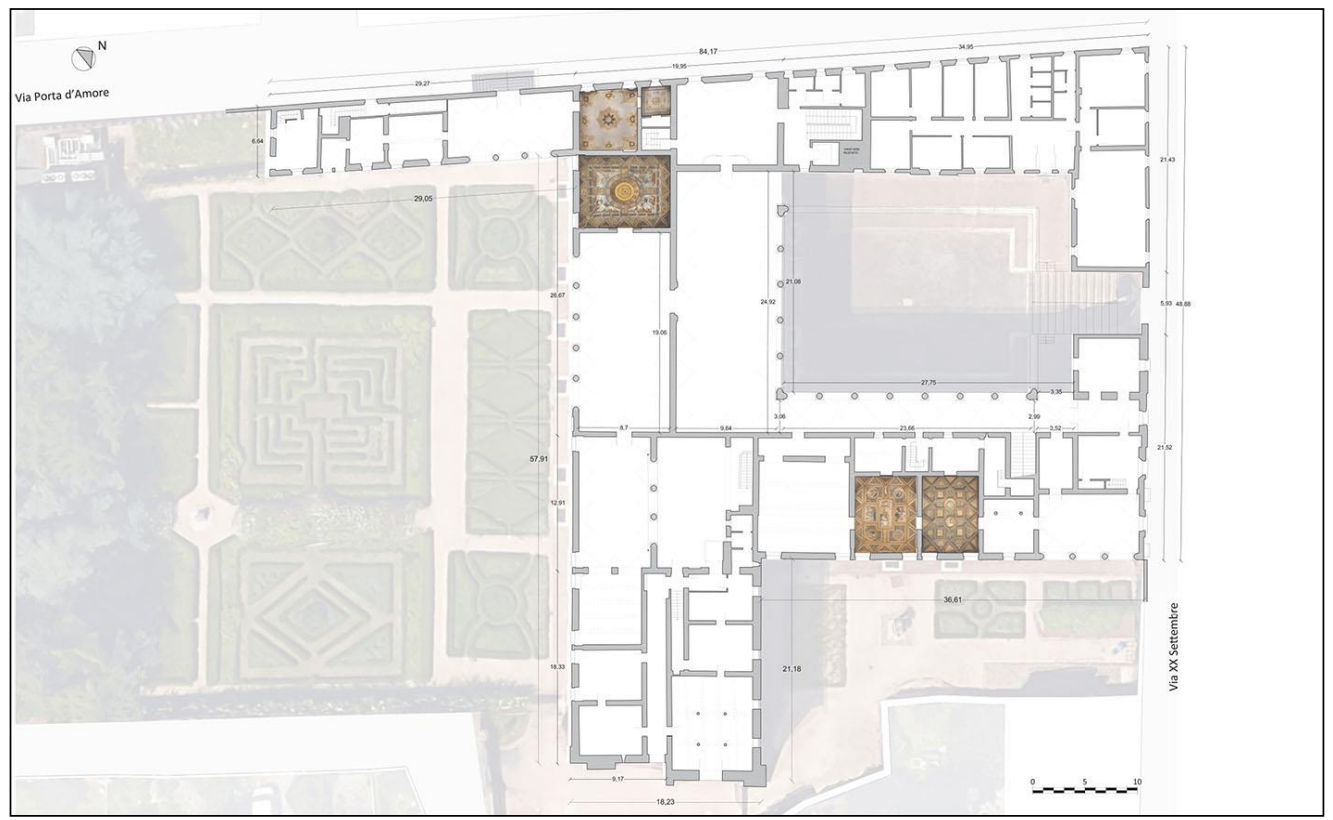

Figure 2. Ground Floor of the Palace

Source: Author. 


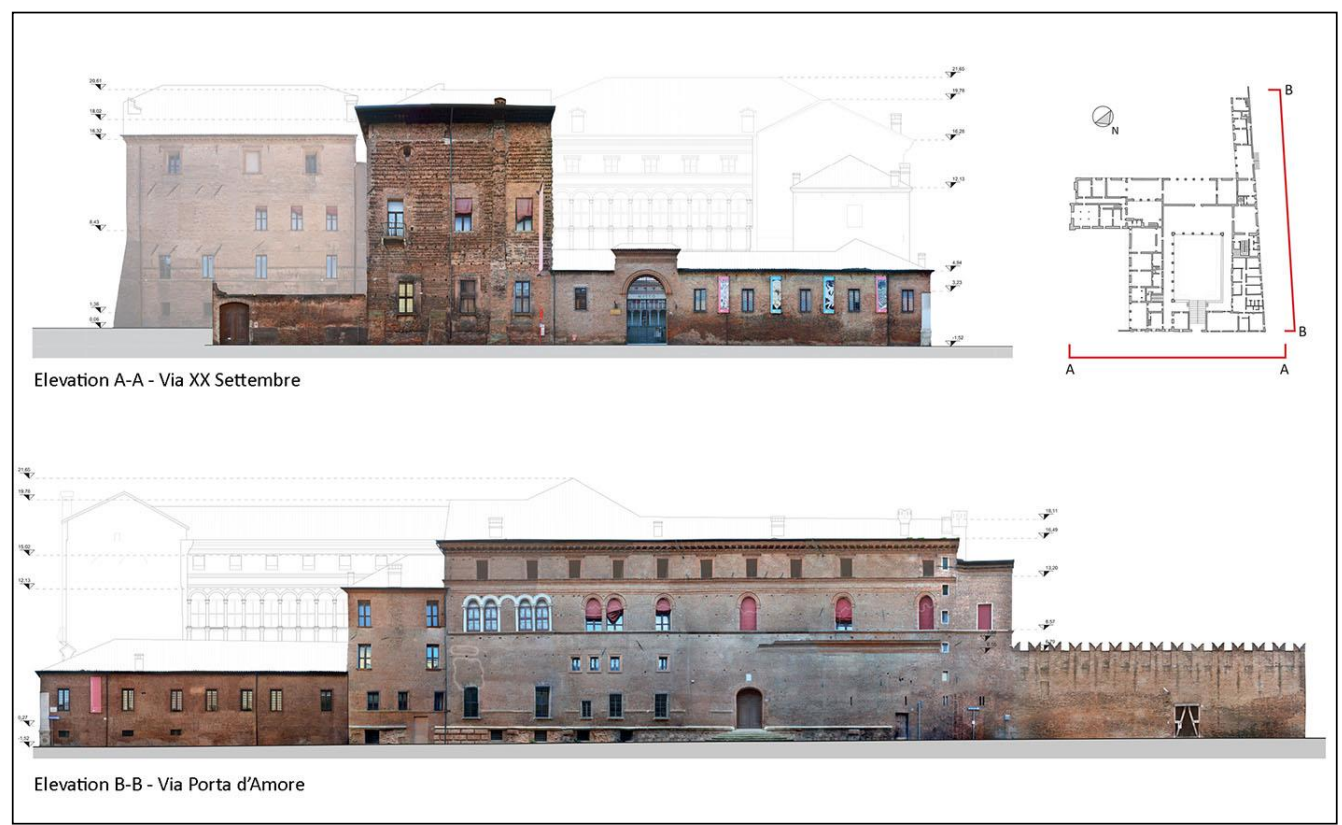

Figure 3. North and West Elevation of the Palace

Source: Author.

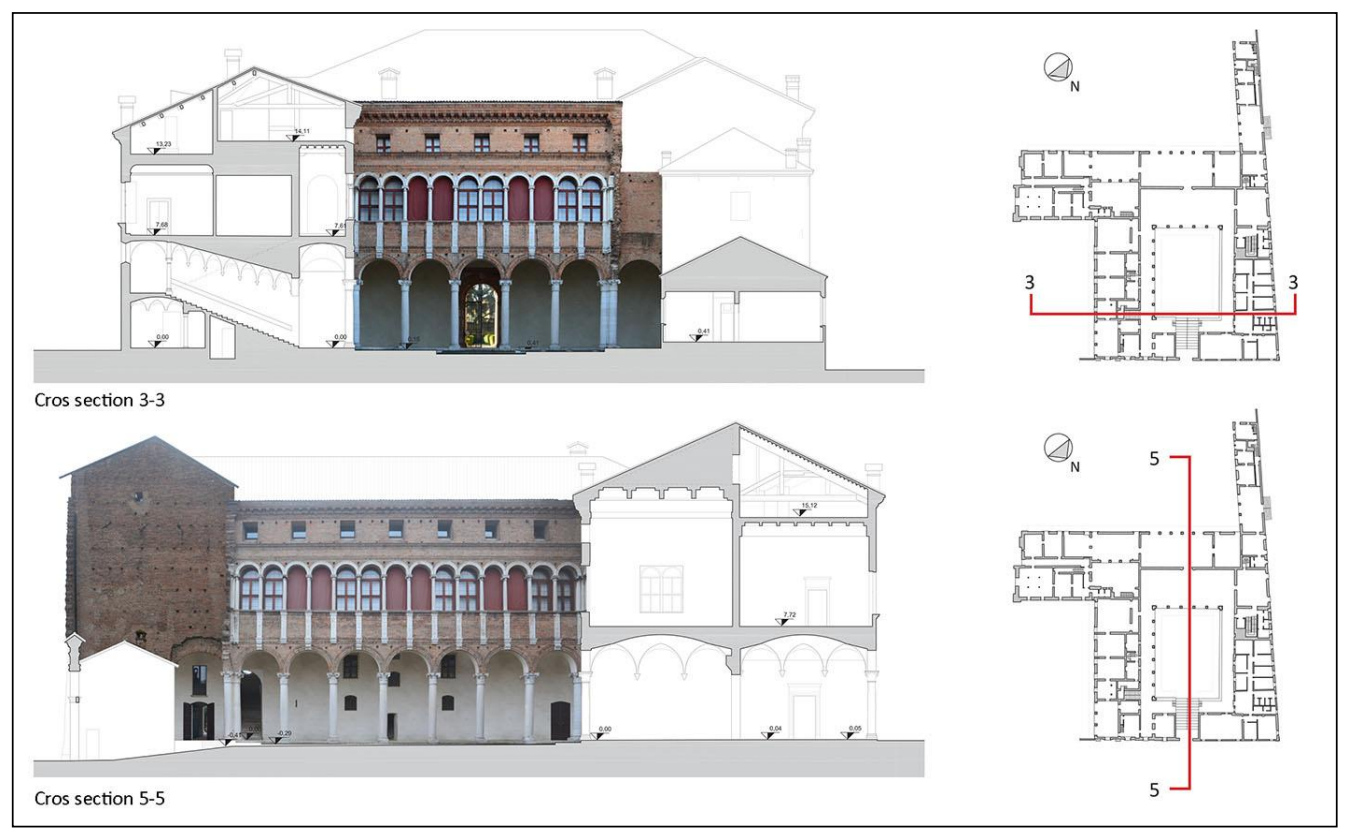

Figure 4. East and South Elevation of the Courtyard

Source: Author.

A literature review and methodology assessment generated the decision to divide the discussion into four subsections. The first looks at the life of Antonio Costabili (mid-1400s-1527) in the context of late fifteenth-early sixteenth century Ferrara, using important unpublished letters from the State Archives in Milan and Modena describing a high profile cultural and political figure. 
The second subsection begins with an urban analysis of the site selected for the palace and continues with a study of its construction during the fifteenthsixteenth centuries using indirect and direct sources.

The third subsection explores the history of renovations to the palace, with a particular focus on the work carried out between 1932 and 1935. This renovation is presented for the first time based on an ordering of historic documents conserved in the archives of Ministry of Cultural Heritage of Ravenna, Ferrara and Rome. Drawings and photographs from before and after the restoration were analysed and overlapped with the current situation. A reading of this material revealed the extent of demolitions to the sixteenth century palazzo during the 1930s restoration works, and to what degree the building we observe today is the result of the interpretation of the Renaissance typical of those years.

The fourth subsection looks at the new language of antiquity adopted in latefifteenth century in Ferrara and the attribution of the design of the palace.

\section{Literature Review}

A survey of past studies exposed the lack of a unified and organic reading of a building defined "magnificis aedibus" by Celio Calcagnini, ${ }^{1}$ with a courtyard described by Burckhardt ${ }^{2}$ (1860) as "worth ten palaces, despite being only halffinished". The palace occupies an important position in the history of Renaissance architecture as the result of an encounter between various Italian schools, at a time of transition that would give birth to the unified architecture of the sixteenth century, as Giovannoni ${ }^{3}$ (1936) writes.

Guarini $^{4}$ (1621) was the first to propose Ludovico Sforza as the client of the palace in Ferrara. This tradition was taken up by Scalabrini ${ }^{5}$ (1773), Frizzi $^{6}$ (1787), Avventi $^{7}$ (1838), Agnelli $^{8}$ (1902) and Alfieri ${ }^{9}$ (1955). Padovani ${ }^{10}$ (1930) was the first to question this legend, citing the absence of any documentary proof and fundamental archival material from 1502 to 1503 explicitly listing Antonio Costabili as the client. However, in 1955 Padovani ${ }^{11}$ himself claimed that the possible dating of the start of construction made it impossible to categorically

1. C. Calcagnini, Opera Aliquot (Basilea, 1544), 436.

2. J. Burckhardt, Storia del Rinascimento in Italia (Torino: N. Aragno, 2006), 324.

3. G. Giovannoni, "Ferrara. The Palace of Ludovico il Moro," in Rassegna di Architettura, no. 8-9 (Milano: Graphic Institute, 1936), XXIV-XXVI.

4. M. A. Guarini, Compendio Historico dell'Origine, Accrescimento e Prerogative delle Chiese, e Luoghi pii della Città e Diocesi di Ferrara (Ferrara, 1621), 294-295. 288-289.

5. G. A. Scalabrini, Momorie Istoriche delle Chiese di Ferrara e de' Borghi (Ferrara, 1773),

6. A. Frizzi, Guida del Forestiere per la Città di Ferrara del Dott (Ferrara, 1787), 135-136.

7. F. Avventi, Il Servitore di Piazza: Guida per Ferrara (Ferrara: Pomatelli, 1883), 153-155.

8. G. Agnelli, Il Palazzo di Lodovico il Moro in Ferrara (Ferrara: Zuffi, 1902).

9. N. Alfieri, Il Palazzo Detto di Ludovico il Moro (Rovigo: STER, 1955).

10. G. Padovani, "Biagio Rossetti e il Palazzo di Antonio Costabili," in Corriere Padano (Ferrara: Soc. An. Emiliana, 1930).

11. Padovani, Architetti Ferraresi (Rovigo: STER, 1955), 82. 
exclude Sforza. Marcianò ${ }^{12}$ (1991) admits the hypothesis of a direct commission by Sforza citing a letter from 1493 in which the Milanese duke, struck by the beauty of the Duke of Ferrara's country villa known as Belriguardo, declares his desire to construct a residence in Ferrara.

The writings of Varese ${ }^{13}$ (1973) began to shed light on Antonio Costabili's importance at the court of Ferrara and affirm the idea that the Ferrarese count could have been the client who commissioned the palace. This hypothesis was taken up by Pattanaro ${ }^{14}$ (1994) and reinforced in the studies of Fidozzi and Guelfi ${ }^{15}$ (2007), who noted that the city's ruling class, to which Costabili belonged with full title, was as capable of producing high quality artistic works as the dukes.

The writings of Cittadella ${ }^{16}$ (1844) proved fundamental to understanding the history of the palace's construction. Together with the publication of archival documents from 1502 to 1503 , they provide certain dating for a construction site that was already underway by this time. The work of Calzecchi Onesti ${ }^{17}$ (1936) made it possible to hypothesise the chronological phases of construction. Padovani (1955) places the beginning works between 1495 and 1498 if the client was the Milanese duke, or 1499-1500 if this role is instead to be attributed to Antonio Costabili. Pattanaro (1994) provides unpublished archival evidence of a testimonial ${ }^{18}$ from 1507 in which the palace is presented as still in fieri.

A decisive understanding of the history of the palace's construction came with the robust publication by Adriano Franceschini, ${ }^{19}$ to whom we owe the transcription of almost all of the documents conserved in diverse Archives relative to the artists present in Ferrara between 1341 and 1516. In particular, the volumes relative to the years 1472-1492 and 1493-1516, published between 1995 and 1997, continue to be a source of important discoveries for historians. The documents provided by Franceschini permitted Baretta ${ }^{20}$ (1998) to offer a more precise history of the palace's construction during the final years of the fifteenth century and the early years of the sixteenth century.

12. A. F. Marcianò, L'Età di Biagio Rossetti. Rinascimenti di Casa d'Este (Ferrara-Roma: Gabriele Corbo Editore, 1991), 115-126.

13. R. Varese, "Il Palazzo di Costabili (Detto di Ludovico il Moro,)" in Spina. Museo Archeologico Nazionale di Ferrara (Bologna: Calderini, I-XXV).

14. A. Pattanaro, "Garafolo e Cesariano in Palazzo Costabili a Ferrara," in Prospettiva (Firenze: Centro Di, 1994), 97-110.

15. I. Fedozzi and B. Guelfi, "Nuovi Documenti e Ipotesi di Lavoro su un Committente Ferrarese nell'Età di Alfonso I: il Conte Costabili," in Il Camerino delle pitture di Alfonso (Padova: Bertoncello Arti Grafiche, 2007), 65-76.

16. N. Cittadella, Indice Manuale delle Cose Più Rimarcabili in Pittura, Scultura, Architettura della Città e Borhi di Ferrara (Ferrara, 1844), 67-69.

17. C. Calzecchi Onesti, "Il Palazzo detto di Lodovico il Moro, Cenni Storici e Critici e Relazione sui Restauri," in The Spina Museum in Ferrara (ed.) S. Aurigemma (Ferrara: Municipality of Ferrara, 1936).

18. Pattanaro, Garafolo e Cesariano in Palazzo Costabili a Ferrara, 1994, 98.

19. A. Franceschini, Artisti a Ferrara in Età Umanistica e Rinascimentale. Testimonianze Archivistiche (Ferrara-Roma: Gabriele Corbo Editore, 1997).

20. S. Baretta, "Il Palazzo di Ludovico il Moro," in F. D. Bollettino della Ferrariae Decus (Ferrara: Este Edition, 1998), 7-22. 
Regarding the history of renovations, the works carried out between 1932 and 1936 drew harsh criticism from Alfieri (1955), Zevi ${ }^{21}$ (1960), Di Francesco ${ }^{22}$ (1996) and Sambin $^{23}$ (2018) for the choice to demolish the walls closing two bays of the colonnade, every two bays, on the second order of the internal courtyard following their presumed attribution to Donato Bramante.

The attribution of the design of Palazzo Costabili was initiated by Cittadella (1844). Using archival material from 1502 and 1503, he was the first to place the architect Biagio Rossetti and the stone mason Gabriele Frisoni on site. Successively, diverse scholars, such as Agnelli (1902 and 1909), Reggiani ${ }^{24}$ (1907) and Righini ${ }^{25}$ (1911) accepted Rossetti as the designer, citing both these documents and stylistic analogies with other coeval buildings attributed to the architect.

In 1914 Righini, ${ }^{26}$ followed by Boari, ${ }^{27}$ despite the certainty only a few years earlier of Rossetti's role, claimed that Palazzo Costabili was instead designed by Donato Bramante, and that Rossetti was a "contractor" or "builder". This affirmation arises from the recognition at Palazzo Costabili of the particular composition, above the entire internal courtyard, typical of the architecture of Donato Bramante and far from the language of Rossetti, incapable of such refined decoration. Also in 1914, criticisms were raised against this attribution by both Reggiani $^{28}$ and Zaccarini. ${ }^{29}$

The work of Padovani (1930) and Calzecchi Onesti (1936) introduced the first distinction between the language of composition and the construction of the palace itself from that of the courtyard: while for the former the references were to coeval architecture in Ferrara, the latter instead looked to models outside the city. Successively, in 1955, while reaffirming the total attribution to Rossetti, Padovani nonetheless emphasised the distinction between the architecture of the volumes of the palace and the composition of the courtyard.

A determinant contribution was made by Bruno Zevi (1960), who attributed the design of the palace exclusively to Rossetti for both its formal characteristics and its composition considered typical traits of Ferrarese architecture. In the wake

21. B. Zevi, Biagio Rossetti Architetto Ferrarese il Primo Urbanista Moderno Europeo (Torino: Einaudi, 1960), 320-324.

22. C. Di Francesco, "Palazzo di Ludovico il Moro (Note Storiche,)" in Giardini e Palazzi Rinascimentali di Ferrara. Sviluppo Urbanistico Moderno (Ferrara: Atti del Corso di Aggiornamento, 1996), 194-199.

23. M. T. Sambin de Norcen, "Osservazioni sui Palazzi (1490-1503,)" in Grande cosi Quanto Forse Ignorato: Omaggio a Biagio Rossetti (Ferrara: Grafiche Turato Edizioni, 2018), 49-66.

24. G. Reggiani, I Portali di Ferrara nell'Arte (Ferrara: Tipografia Taddei-Soati, 1907), 102-103.

25. E. Righini, Quel che Resta di Ferrara Antica (Ferrara: Estense Libro, 1911), 55-98.

26. Righini, "Bramante, Rossetti e il Palazzo d Ludovico il Moro," in Gazzetta Ferrarese (Ferrara: Officina della Gazzetta, 1914).

27. A. Boari, "Bramante, Rossetti e il Palazzo d Ludovico il Moro Bramante," in Gazzetta Ferrarese (Ferrara: Officina della Gazzetta, 1914).

28. Reggiani, "Bramante, Rossetti e il Palazzo d Ludovico il Moro," in Gazzetta Ferrarese (Ferrara: Officina della Gazzetta, 1914).

29. D. Zaccarini, "Ferrara. Palazzo di Ludovico il Moro," in Architettura e arti decorative Ferrara (Milano-Roma: Bestetti and Tumminelli, 1922), 304-305. 
of Zevi's important work, Rossetti's authorship was also accepted by Piconi Aprato $^{30}$ (1972), Varese ${ }^{31}$ (1979), Marcianò (1991) and Di Francesco (1996); Pattanaro $^{32}$ (2009 and 2018) and more recently by Sambin De Norcen ${ }^{33}$ (2018) through analogies with Belriguardo, and for a language distant from the reference to antiquity matured by Bramante as early as the late fifteenth century.

\section{Methodology}

The methodology ${ }^{34}$ utilised in the study of Palazzo Costabili, after examining the level of existing studies and looking at issues yet to be explored, overlays results provided by direct and indirect sources.

The former were catalogued for bibliographic, archival, iconographic and cartographic research. A chronological register allowed for the identification of certain dates, contradictions, temporal gaps and differing interpretations of the history of the palace's construction.

Direct sources consist of an architectural survey, enriched by additional sections, plans and details, a typological survey and a photogrammetric mapping of the elevations and vault decorations. Direct analysis was used to investigate the building's different construction systems, from the foundations to the roof. This process identified anomalies, alignments, the opening and/or closure of doors and windows, surveyed and catalogued based on differentiations in materials and dimensions, and traces of interruptions and discontinuities in masonry work. An editable version of this survey was used to analyse measurements and proportions by converting actual measurements into Ferrarese feet (equivalent to $0.4039 \mathrm{~m}$ ).

\section{Discussion (together with findings and results)}

\section{The Client: Antonio Costabili}

It is likely that Antonio Costabili ${ }^{35}$ was born in Ferrara in the early second half of the fifteenth century and that he received a military and humanist education.

30. G. Piconi Aprato, "Il Palazzo Detto di Lodovico il Moro in Ferrara," in Ferrarese Museums, Annual Bulletin (Firenze: Centro Di, 1972), 117-128.

31. Varese, "Il Palazzo di Costabili (Detto di Ludovico il Moro,)" In Spina. Museo archeologico nazionale di Ferrara, 1973, I-XXV.

32. A. Pattanaro, "Il Restauro di un Importante Affresco Rinascimentale Apre Nuove Prospettive Storiche," in Ferrara voci di una città (Ferrara: Cassa di Risparmio di Ferrara Foundation, 2009), 39-43.

33. Sambin de Norcen, Osservazioni sui Palazzi (1490-1503), 2018, 49-66.

34. A. Bruschi, Introduzione alla Storia dell'Architettura. Considerazioni sul Metodo e sulla Storia degli Studi (Città di Castello: Mondadori Università. 2009).

35. F. Petrucci, "Antonio Costabili," in Biographical Dictionary of Italians (Roma: Institute of the Italian Encyclopedia, 1984), 257-260. 
His military valour earned him the title of Savour of the State from the Duke. After serving in the military, Costabili moved on to a diplomatic career. He served as ambassador in Milan under Duke Ludovico Sforza (1494-1499) from 1496 to 1499. Costabili's service under Duke Sforza earned him the title of "Familiare" and "Consigliere di Ludovico". He had the privilege of accompanying il Moro to meetings with the Holy Roman Emperor Maximilian I in Tirano and Bormio. In 1498, Maximilian I personally afforded Costabili the privilege of using the black eagle in a field of gold on his personal coat of arms. This herald would later appear on the piano nobile of his palace, on the wood beams of the soffit in two rooms and in the hallway leading from the grand staircase to the main hall (Figure 5).

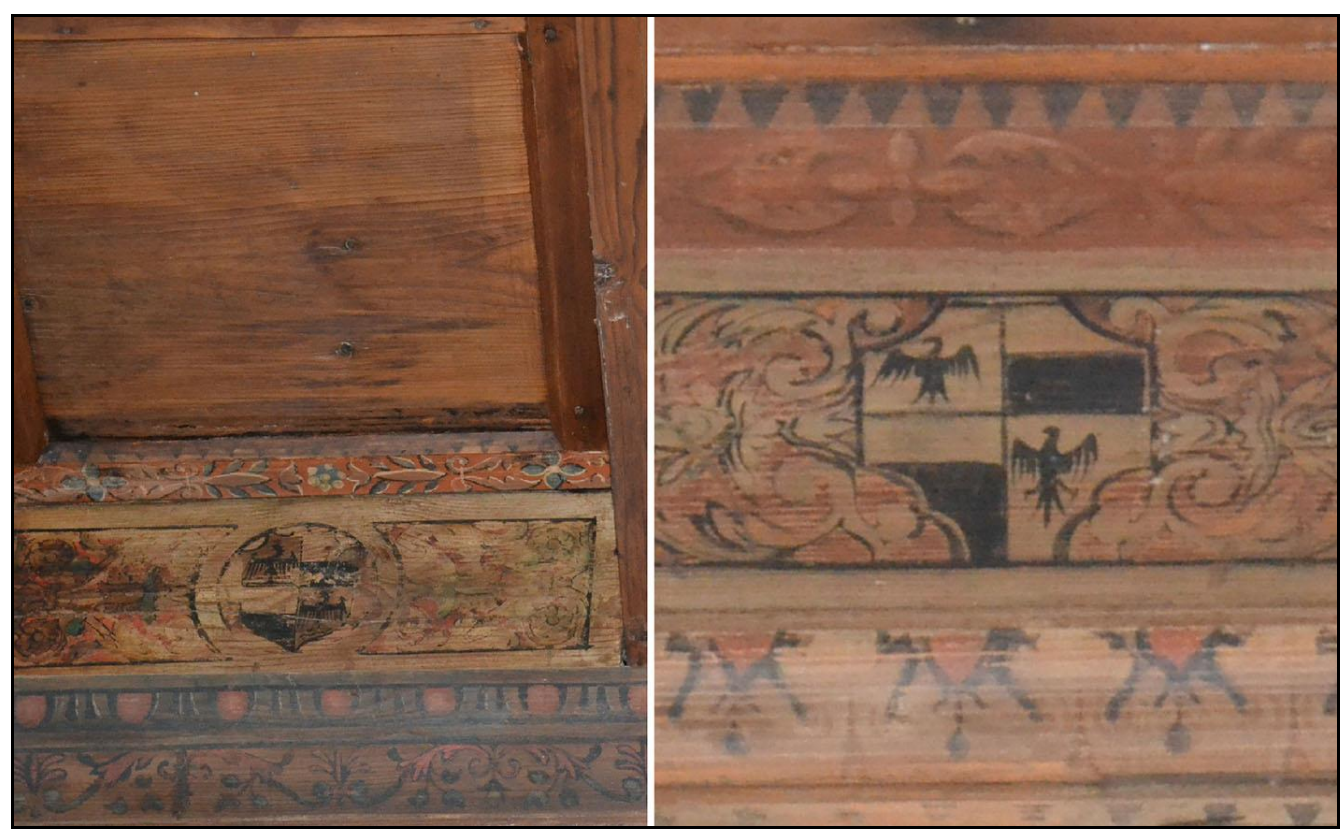

Figure 5. Personal Coat of Arms of Antonio Costabili

Source: Photographs by the Author.

Many of the letters written after 1496 by Costabili to Duke Ercole I d'Este are conserved at the State Archives in Milan. In these letters, the ambassador exercises his role as a key figure in deciding the fate of the Duchy of Ferrara and Milan, within the vaster web of relations and expansionist designs of the kings of France, Spain, Germany and Great Britain, and the Pope with them. The historicalpolitical context in which Antonio Costabili operated as ambassador during the 1490s was crucial to the fragile equilibrium of Italy's various courts, in the climate of pacific accord reached between states with the Peace of Lodi in 1454.

Costabili accompanied Ludovico Sforza until 1499, the year Louis XII, King of France, conquered the Duchy of Milan.

Upon returning to the Duchy of Ferrara, Costabili received important public commissions.

The variety of situations that emerges from a reading of unpublished material conserved at the State Archives in Modena relative to Costabili's return to Ferrara demonstrates a capacity to respond to the accidental development of events with temperance and resolve. The documents describe a multifaceted personality and a 
talent for responding to the most delicate expectations of the Duke regarding the management of possible problems faced by the city (for example to guarantee public order, to control the work site of the new city walls and to manage the emergency of the plague).

The capacity to observe, evaluate and even modify an order while it was being carried out, with total transparency and loyalty to the Duke, and with an equally lively freedom of judgment, made Costabili a figure the Duke could turn to with extreme familiarity and trust. A man equally able to deal with questions of public order, unafraid to send armed troops ${ }^{36}$ when necessary, as well as the most private questions; for example celebrating to Duke Alfonso I the virtues of his wife, the Duchess Lucrezia Borgia, and the healthy growth of their son Ercole. Costabili's many letters, the last, about the plague in Ferrara, dated June 12, 1527, two months prior to his death, paint the portrait of a man devoted to his Duke, his city and its citizens.

As mentioned, Antonio Costabili was also linked to the delicate international political questions that arose in the late fifteenth and early sixteenth centuries. On more than once occasion his role proved decisive and his friendships made him indispensable to the d'Este Dukes, initially Ercole I, and Alfonso I after him. The descendent of a prestigious family, which had already occupied important public positions, Antonio established an even denser network of political, as well as cultural exchanges, no doubt with Milan, thanks to his time there as the Sforza's ambassador, but also in Rome, thanks to his close relations with his brother Beltrando, ambassador to the Roman Curia.

A fundamental part of this study is the development of an entirely new understanding of Antonio Costabili within the humanist culture of the Ferrara court in the fifteenth and sixteenth centuries. What emerges is a figure of impressive cultural depth, perfectly inserted within the humanist climate that already permeated the court since the first half of the 1400s.

The programme of frescoes desired by Costabili for his palace under construction reveals to what degree the literary and figurative culture of its client reflected a frequentation, a habit of familiarity with the most cultured protagonists of the Ferrara court, which welcomed the most sensible new artistic movements. From his education, Costabili shared the virtues of the circle of humanists, present at court in Ferrara. They substantiated the ethical values of antiquity, as demonstrated by Costabili's anything but casual choice of the poem Anteros sive de mutuo amore, by the humanist Celio Calcagnini, for his "Treasure Room", the most intimate and precious space in the palace (Figure 6).

36. State Archive in Modena, "Cancelleria Marchionale poi Ducale Estense," bag 7, letters of 3 July 1499, 23 August 1510, 25 May 1518. 


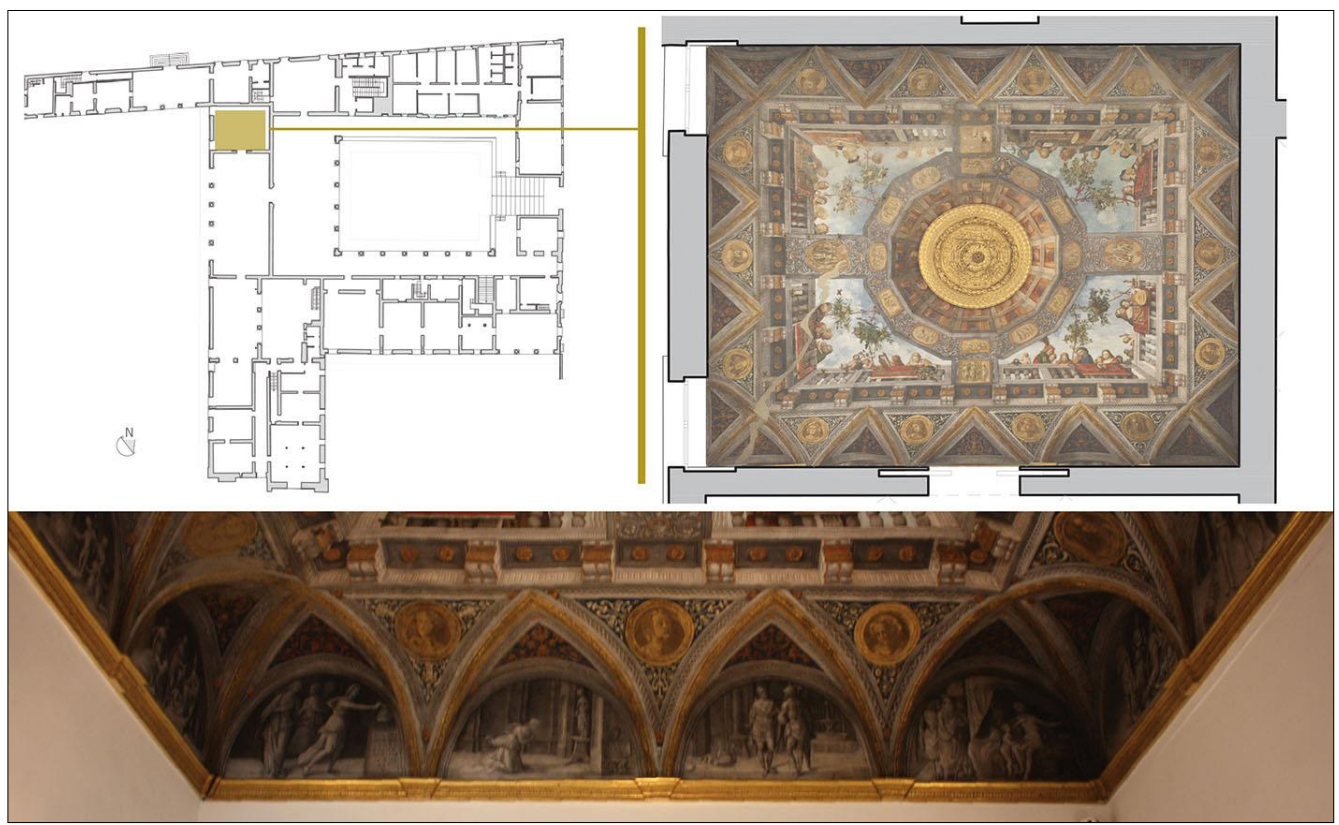

Figure 6. Identification of the "Treasure Room" in the Costabili Palace

Source: Survey, Photomap and Photograph by the author.

Costabili was familiar with the expressions of ancient literary culture and it was to these values that he dedicated the decorations of the rooms in his palace, reflecting the words written by Calcagnini in the introduction to his poem: "Your numerous commitments on behalf of citizens and the community should testify to your devotion and generosity: yet, as the Greeks thought, a man's mettle is understand through his words, you have advanced the idea of specific praise for you in your marvellous home where you exhibit your benevolence and your grateful attention through friendship."37

Exemplary for comprehending the importance of their reciprocal friendship, typical of an ancient humanist culture, is an unpublished letter ${ }^{38}$ from May 1496 found in the State Archives in Milan, in which Ercole I d'Este writes to Ludovico Sforza: "(...) We can be certain that your Excellence loves us, as you say, as our love is mutual and reciprocal (...)". For Costabili, the mutual love described by Calcagnini moved beyond the doors of the private room of a noble palace to take form in the words of a Duke in all of his power as a tool of government.

\section{The Erculean Addition and Antonio Costabili}

The phenomenon of urban expansion at the end of the fifteenth century, known as the Erculean Addition, commissioned by Ercole I, saw Ferrara grow in a manner never before conceived by political power. Its study aids an understanding of the relationship between Antonio Costabili and the city. It is also of interest to

37. The translation from the Latin was made by the author.

38. State Archive in Milan, Book 337, Letter of 16 May 1496. 
the relationship between the history of the Costabili family and political power reflected in the choice of the site of Antonio's palace.

The ancient city was far from the Erculean Addition. Its original nucleus was in an area to the south-east, known as the Polesine di Sant'Antonio, reclaimed less than fifty years earlier. This was the area in which Antonio Costabili chose to erect his palace.

It is important to note that Antonio's father, Rainaldo Costabili, served as a counsellor to Borso d'Este and Ercole I d'Este and possessed lands acquired in the area of Sant'Antonio in Polesine and properties in the Erculean Addition.

Antonio Costabili could thus choose the site for his palace from among two equally advantageous locations, as his father's possessions afforded him lands in either the old or the new city. The choice fell on the older part of Ferrara, where he proceeded to erect a palace of unprecedented dimensions on a narrow strip of land in the ancient city, a few dozen metres from the river. At the time, this area was home to three-storey constructions generally no wider than a few dozen metres. ${ }^{39}$ Other than being the oldest part of the city of Ferrara, the Polesine di Sant'Antonio was also home to the Costabili family, as we know from a document dated February 6, 1497. The same letter also speaks of the desire expressed by Antonio's brother, Beltrando Costabili, who boasted important commissions at the Cathedral of Ferrara, to build a home in the Polesine di San Antonio. The same area was already home to the Augustinian convent of Sant'Andrea, the burial place of the Costabili family, and whose high altar had been commissioned by Antonio Costabili himself.

\section{The History of the Palace's Construction}

Archival material offers evidence of land purchases in the Polesine di Sant'Antonio by Costabili on May 14, 1495, and another purchase the same year, though it was registered only in 1497.

Following these acquisitions, indirect sources show payments beginning in October 1495, and later in 1496, 1497 and at two moments in 1498, made by ducal bankers on behalf of Antonio Costabili. Given their dimensions, in particular those listed in the act from May 1495, these terrains are most likely those acquired for the construction of the palace. Indirect sources would seem to support a hypothesis of an intention to begin construction between 1495 and 1496.

The fact that Palazzo Costabili was built on pre-existing constructions is additionally confirmed by direct sources: an analysis of the thickness of the walls matches that of the row houses typical of the area of Sant'Antonio in Polesine. This same dimension was used to structure the south wing where it faces both the garden and the courtyard. This southern block was the first to be erected during an initial phase of construction datable to between 1496 and 1501 (Figure 7).

39. C. Nardelli, and M. Tassotti, L'Addizione di Borso: Analisi dell'Edilizia Storica sull'Asse Quattrocentesco di via Ghiara: Individuazione del Limite Fisiologico di Trasformazione degli Organismi Edilizi Finalizzata alla Loro Conservazione. Master's Degree Thesis (University of Ferrara, 2009). 


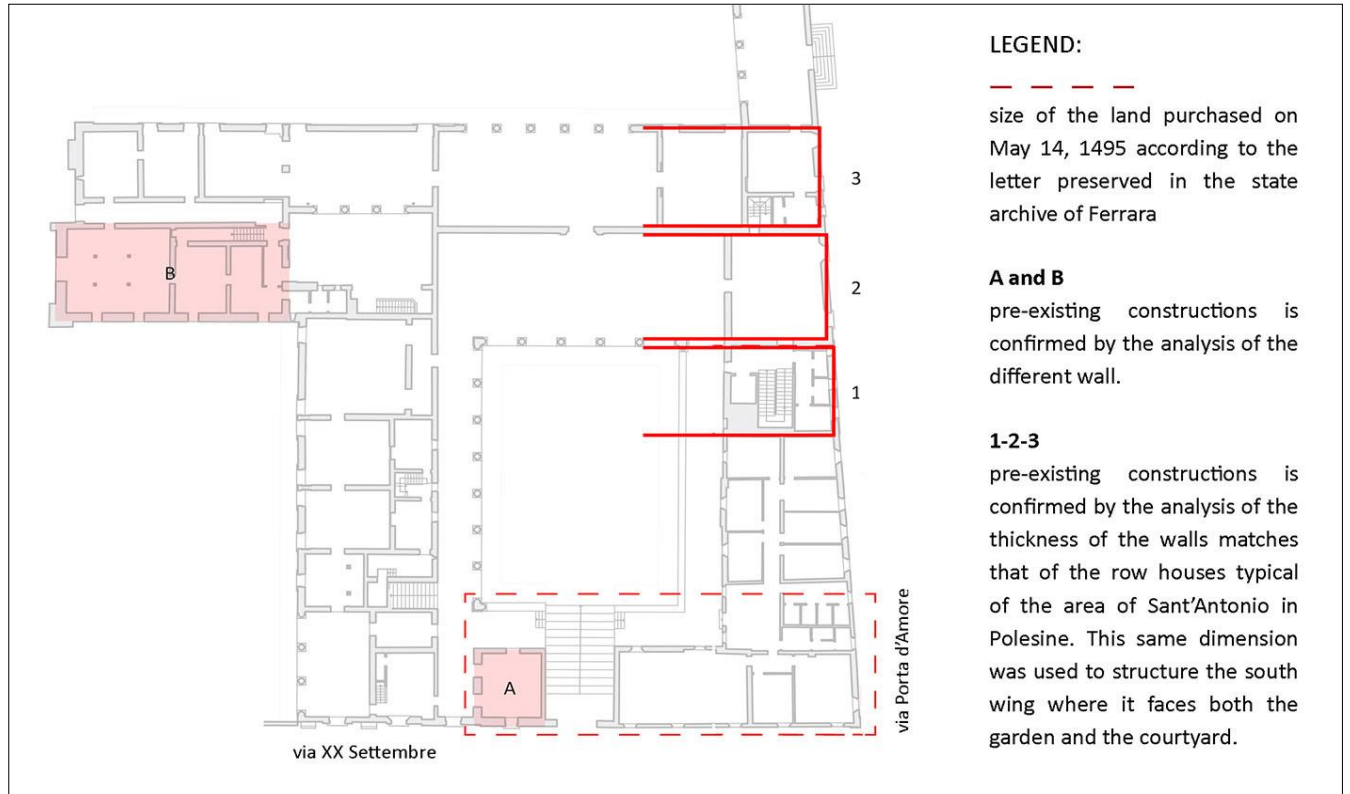

Figure 7. Identification of the Pre-Existing Constructions in the Costabili Palace through the Analysis of the Wall

Source: Survey by the Author.

Archival documents take us to 1501, when Maestro Antonio di Gregorio stone mason, a resident of the same quarter as Costabili, commits to supplying six columns and other works in marble. ${ }^{40}$ The six columns motioned in these documents are those of the two loggias facing the garden (Figure 8).

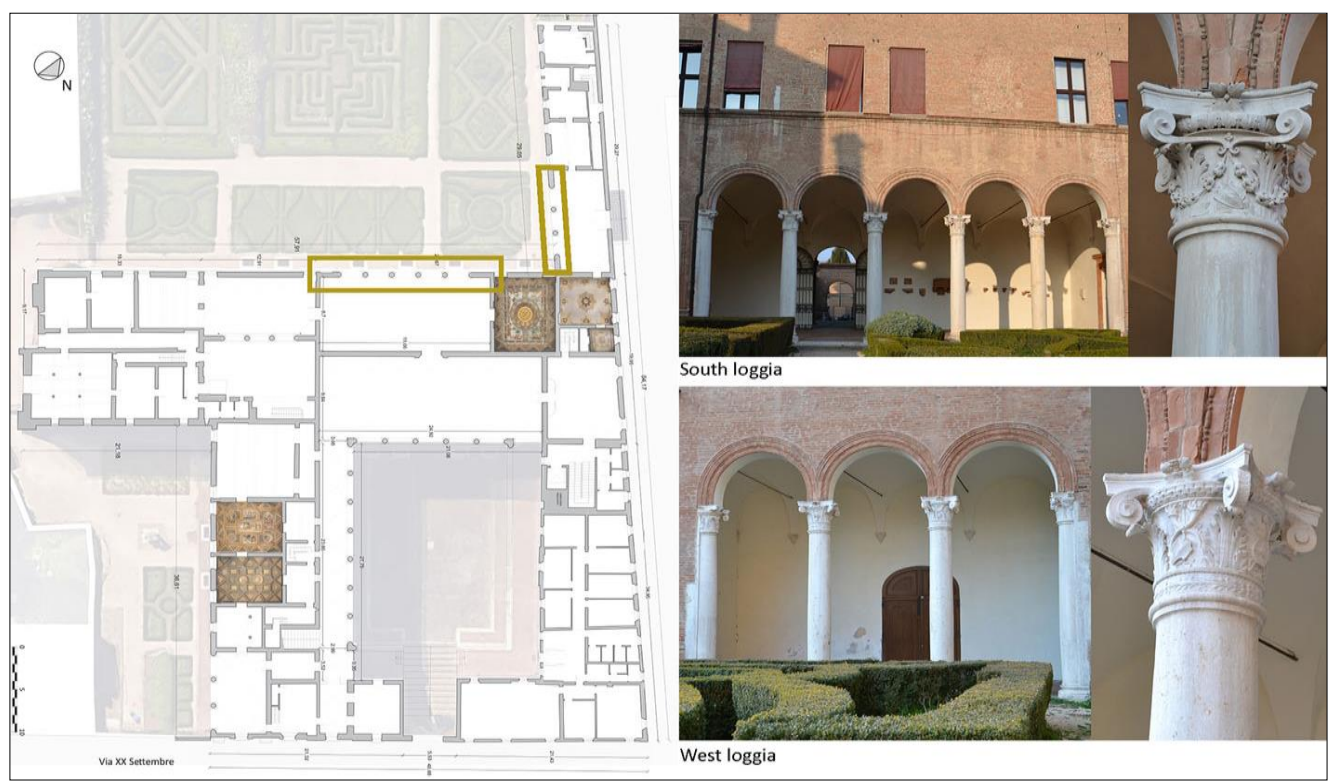

Figure 8. Identified to the Left on the Survey of the Ground Floor Are the Two Loggias towards the Garden (Identified with Yellow Boxes)

Source: Survey, Photomaps and Photographs by the Author.

40. Franceschini, Artisti a Ferrara in Età Umanistica e Rinascimentale. Testimonianze Archivistiche, 1997, 477. 
From this we can infer that by 1501 the south block of the palace, facing Via Porta d'Amore, as well as the garden, were under construction.

Archival sources list Antonio di Gregorio's death in $1502 .{ }^{41}$ This appears to be the most plausible explanation for the arrival on site of another stone mason: Gabriele Frisoni. Three documents from April $1502^{42}$ containing written acts with the Client Antonio Costabili, define diverse roles on site and relations between trades. Biagio Rossetti is listed as the guarantor for the mason Tristano and the stone mason Frisoni. It is important to note that, like Maestro Antonio di Gregorio, both Biagio Rossetti and the mason Tristano hail from the same quarter as Antonio Costabili.

However, one year later, in September $1503^{43}$ Biagio Rossetti and Frisoni, handed the works over to Maestro Girolamo Pasini "a smith" and Maestro Cristoforo, stone mason. A fundamental part of this document is its reference to a notarised act dated $1502^{44}$ and signed by Rossetti and Frisoni for all of the marble work necessary for Antonio Costabili's building site. All of the material listed as of April 1502 refers to the conclusion of three sides of the courtyard: east, west and north. The south side had already been defined.

However, one year later, in October $1504,{ }^{45}$ both Maestro Cristoforo da Milano and Maestro Girolamo Pasini resigned from their positions. From this moment onward, the archives contain no further documentation about the construction of the palace.

In terms of composition, direct analysis demonstrates that if the first limit on the realisation of the palace was represented by the pre-existing constructions along Via Porta d'Amore, the second was imposed by the pre-existence of the block to the south-east. At the time of construction of the eastern wing, begun in 1502, a connection was created: a "masonry bandage" can be observed in correspondence with the junction between the two blocks (Figure 9).

As work progressed in 1502, either more errors were made, or numerous variations were introduced. The first error takes the form of what appears to be a failed alignment between the corner column to the north-east of the internal courtyard and the entrance to the grand stair (Figure 10).

41. State Archive in Milan, "Camera Ducale Estense, Munizioni e Fabbriche," book 39, letter of 31 Dicember 1502.

42. Franceschini, Artisti a Ferrara in Età Umanistica e Rinascimentale. Testimonianze Archivistiche, 1997, 125.

43. Ivi, 431.

44. Ivi, 262.

45. Ivi, 481. 


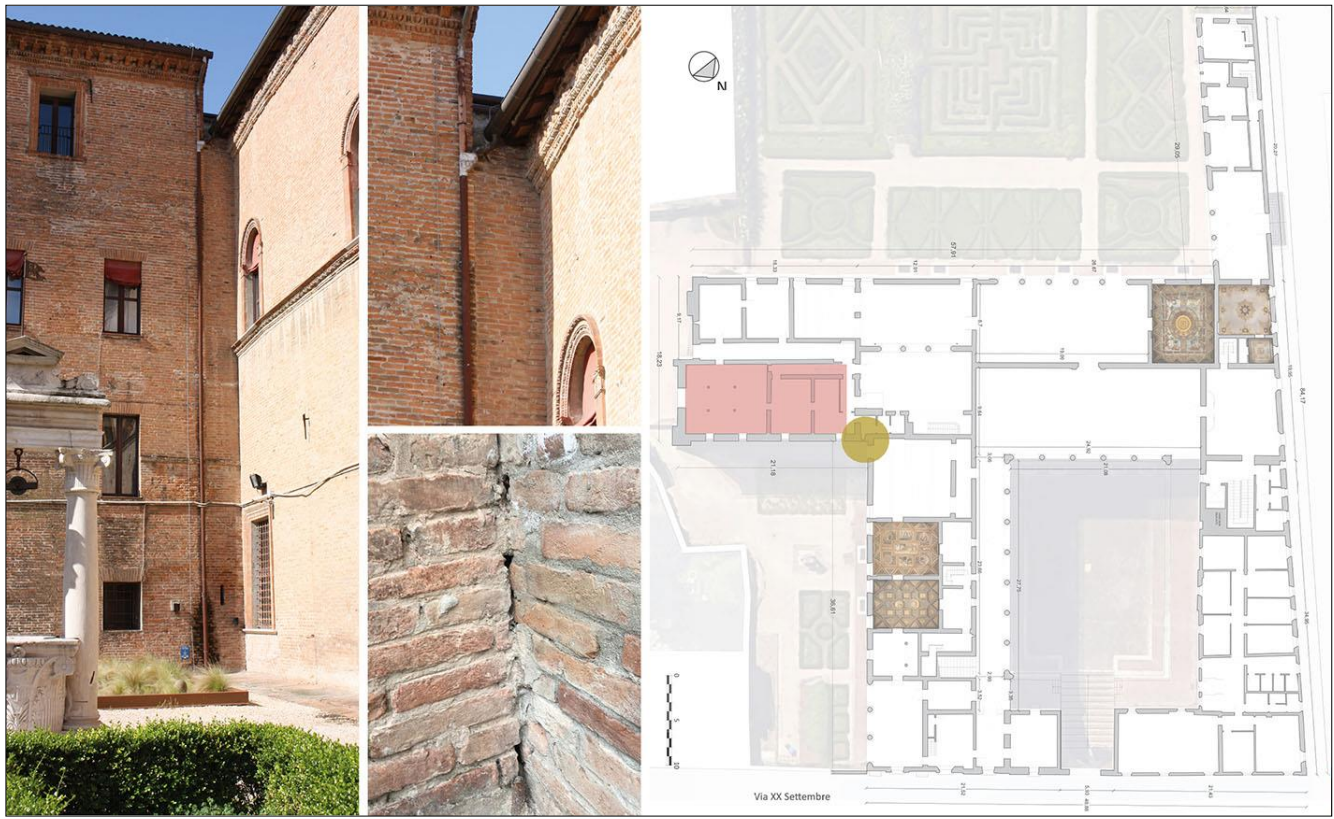

Figure 9. The "Masonry Bandage" (Identified with a Yellow Circle on the Plan) between the Pre-Existing Construction (in Red on the Plan) and the New Construction of Palazzo Costabili to the East

Source: Survey, Photomaps and Photographs by the Author.
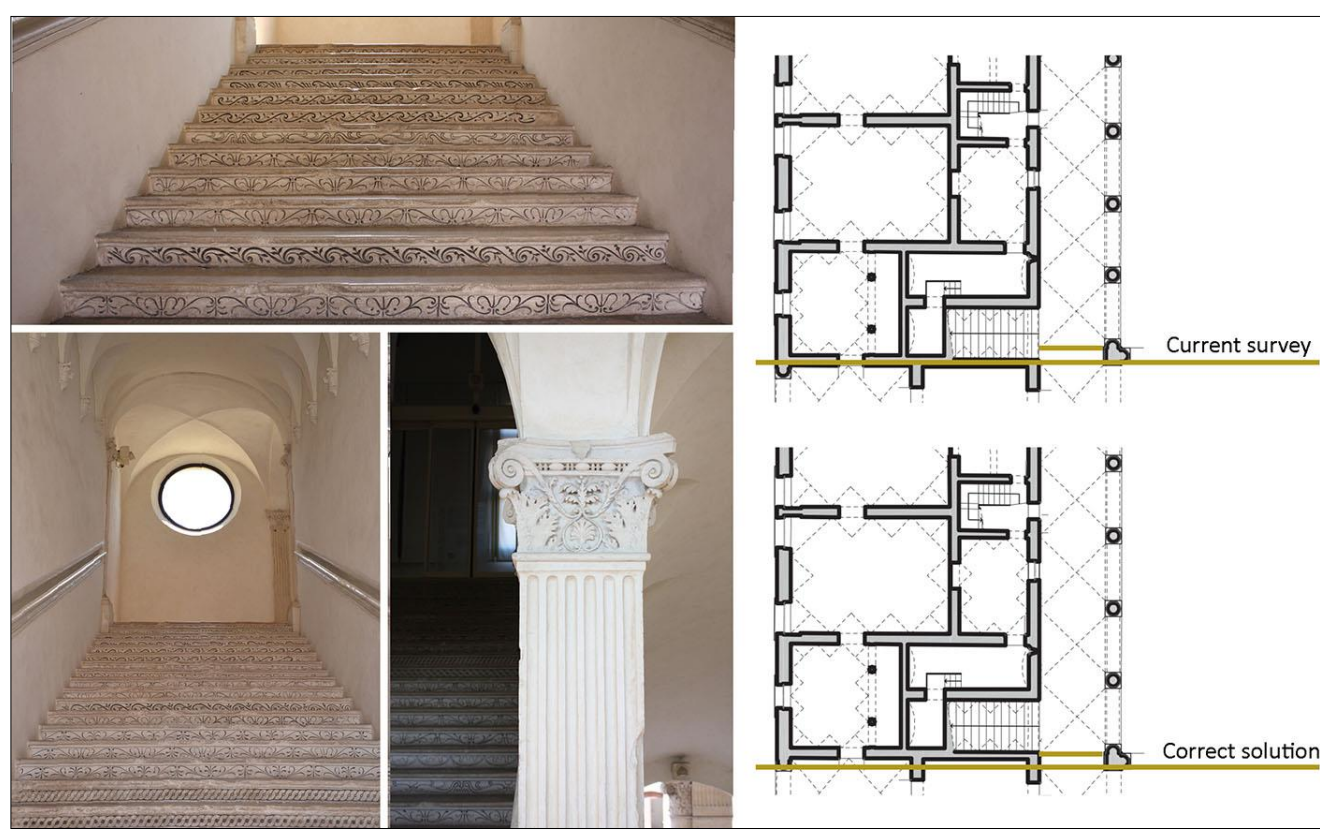

Figure 10. On the Left, Images of the Decorations of the Grand Stair; on the Right, the "Error" in the Architectural Composition between the Courtyard and the Grand Stair

Source: Survey and Photographs by the Author.

A second variation was made to the grand stair: the 1502 materials list speaks of 44 steps, with a perfectly proportioned ratio between riser and tread of 2:1. However, these measurements do not match what was actually built: the length of 
the steps corresponds only with a portion of the wall, which is later reduced on the inner side of the stair, as demonstrated by the survey. If we construct a stair with the dimensions and number of steps in the document from 1502, we would end up with a landing in correspondence with the room below, where we would find the two free columns on the ground floor on axis with the fluted pilasters of the stair. This would have created two perfectly coinciding rooms, one on the ground floor and one at the level of the landing (Figure 11).

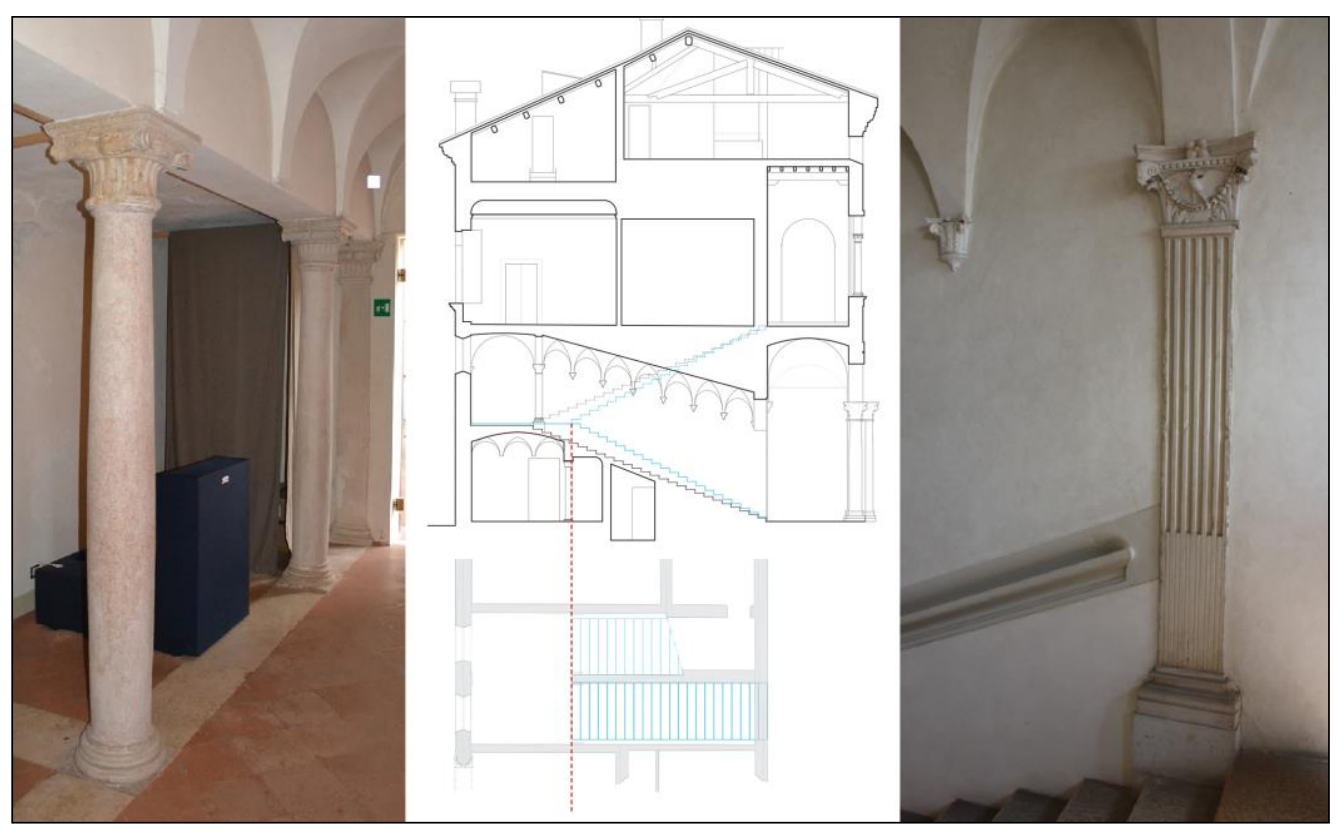

Figure 11. On the Left, the Column at the Ground Floor Level; on the Right, the Pilaster at the Landing of the Grand Stair Level. In the Center, a Cross Section Drawing Marks in Blue how the Grand Stair Could Have Been Built according to the Archive Documents

Source: Survey and Photographs by the author.

Until 1502 it would appear that there existed a project, however, during construction and with the changing of trades there seems to have been some difficulty in maintaining or building this original design. This would seem to explain the variations observed in plan.

Similar conditions can also be found in the elevations. Beginning with the elevation along Via Porta d'Amore, the brick rustication of the base course of the palace was left unfinished. This rustication, however, was started at the same time as the south block and thus by 1502 . The trabeation above the infilled crenellations of the west elevation, if it were ideally extended, would have arrived above the corner pilaster; all that remains of this element is a portion at the corner of the palace between Via Porta d'Amore and Via XX Settembre. The fluting of the corner pilaster begins at one third of the shaft; this datum makes it possible to infer the total height and understand the significance of the two elements that have remained incomplete. The desire to complete this trabeation is demonstrated in the document from 1502 (Figure 12). 


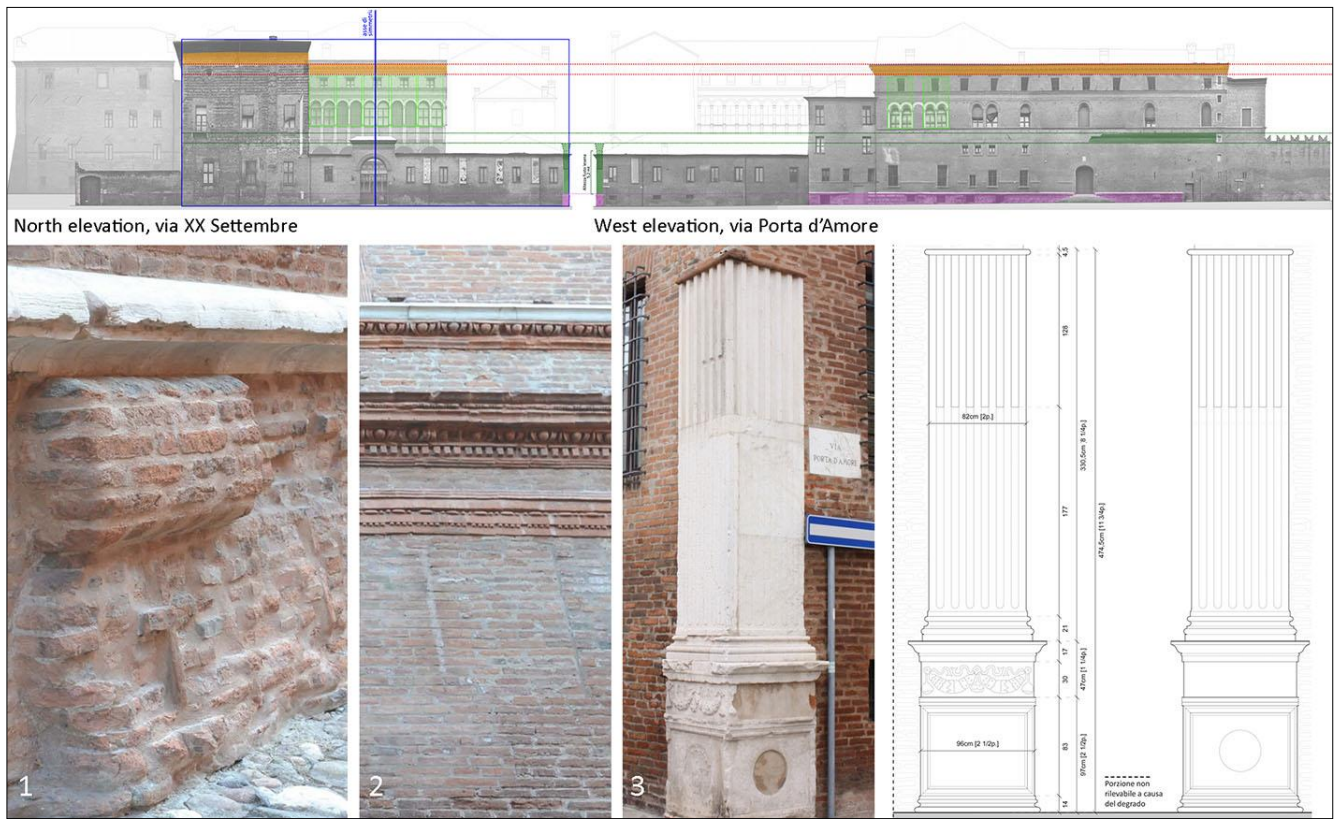

Figure 12. Unfinished Element of the Palace: The Brick Rustication of the Base (1), the Trabeation (2), the Corner Pilaster (3)

Source: Survey, Photomaps and Photographs by the Author.

The terminal cornice on the west elevation finds a formal and altimetric continuity in the cornice of the internal courtyard: proof of the existence of a unified project for these two parts of the palace (Figure 13).

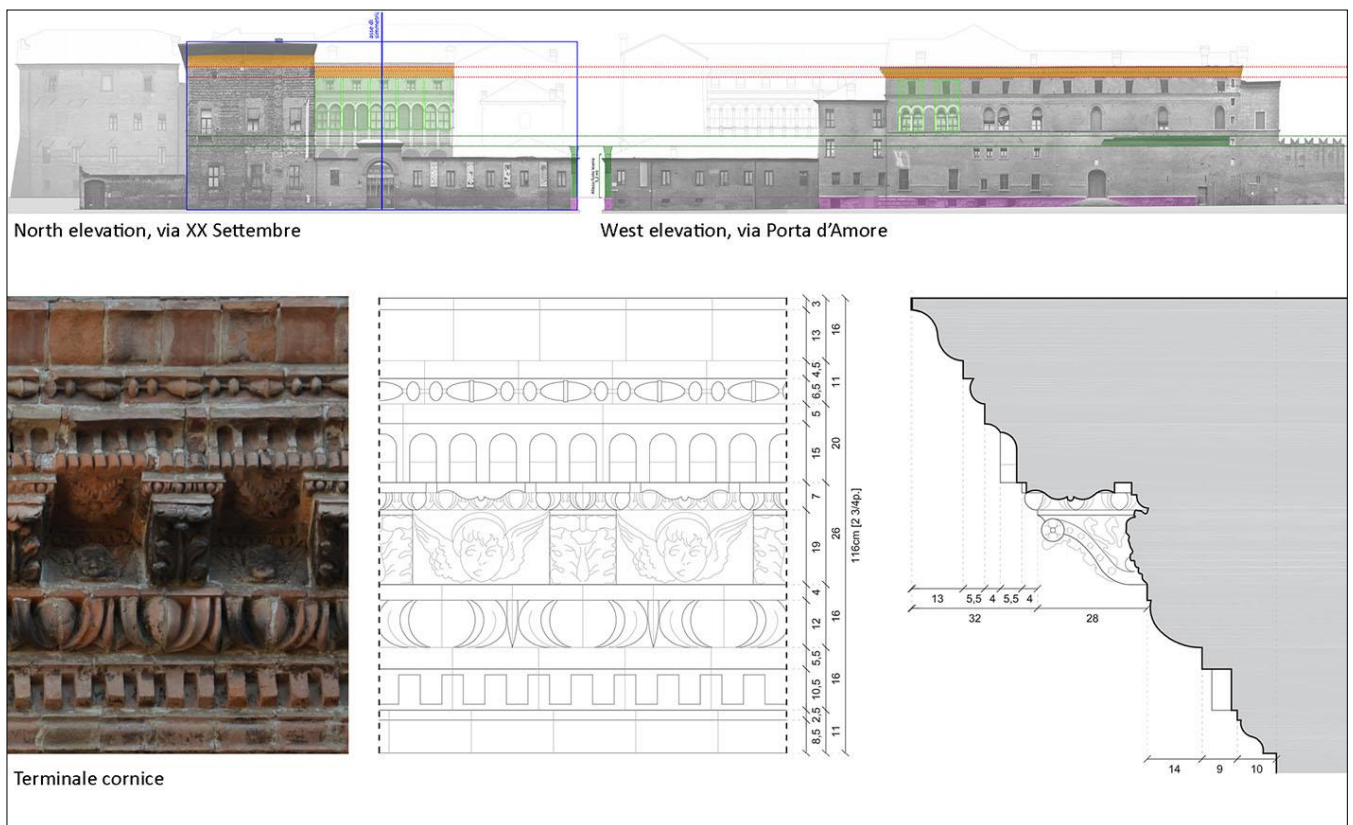

Figure 13. The Terminal Cornice on the West Elevation

Source: Survey, Photomaps and Photographs by the Author. 
There is a project that, in both plan and elevation, perhaps imagined a new language for Ferrara: as demonstrated in the design of the internal courtyard (Figure 14).

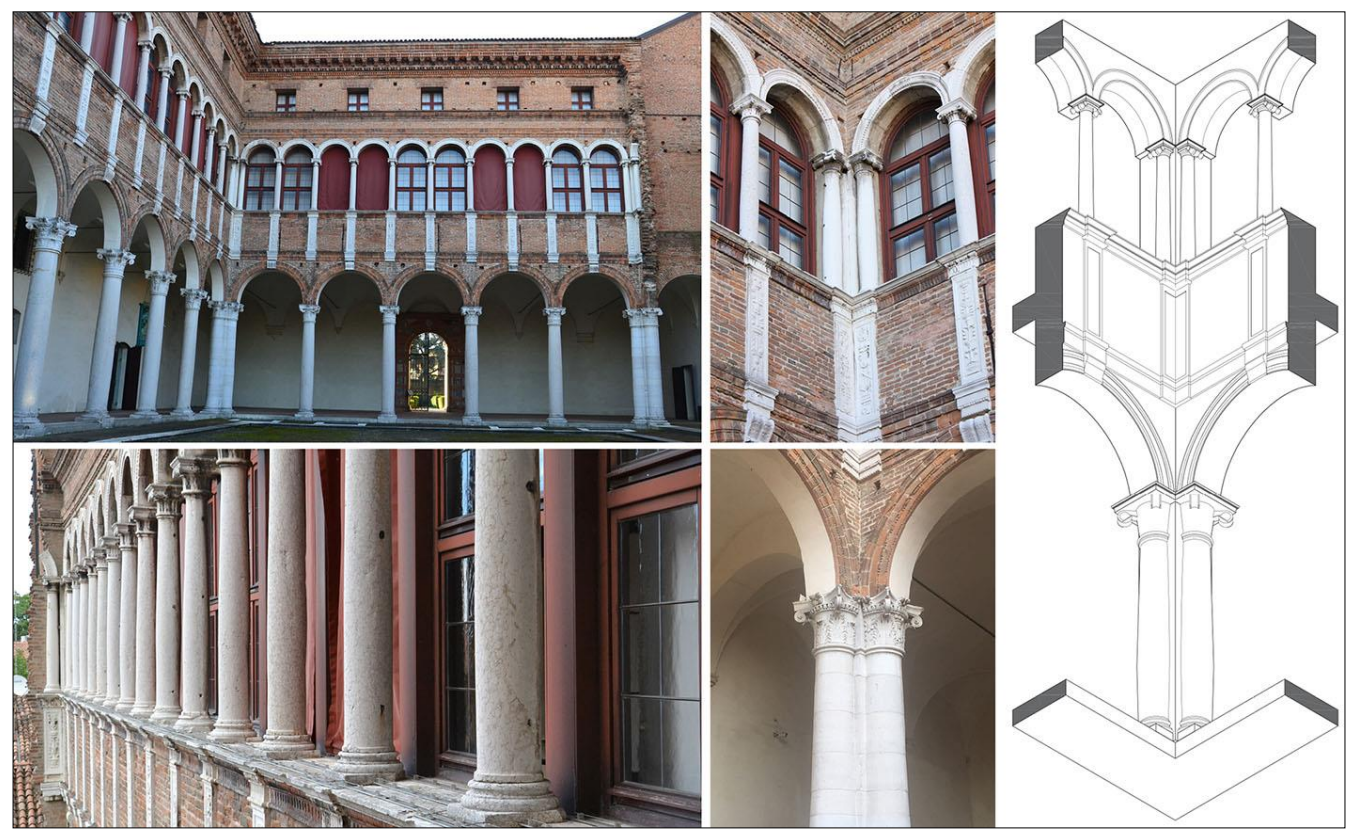

Figure 14. On the Left, Images of the Courtyard and, on the Right, an Axonometric Drawing of the Corner Solution

Source: Survey and Photographs by the author.

A courtyard whose design presents a proportion in elevation with an evident ratio of 2:1 between the first ( 12 Ferrarese feet) and second order (6 Ferrarese feet) and which respects the theoretical rule, ${ }^{46}$ first suggested by Vitruvius, where the upper order is equal to the lower order, after subtracting $1 / 4$ (Figure 15). The elevations correspond, instead, with a proportion of $1: 1$ on the south side and 2:3 (a fifth or diapente) on the east elevation. It appears that, where possible, despite the definition of measurements linked to pre-existing elements, there was a search for a proportionate harmony based on the architecture of "antiquity".

46. M. Vitruvio Pollione, De Architectura (Milano: Polifilo, 1997), 571; L. B. Alberti, L'Architettura (Milano: Il Polifilo, 1966), 808; F. Dg. Martini, Trattati di Architettura, Ingegneria e Arte Militare (Milano: Il Polifilo, 1967), 86; S. Serlio, Architettura Civile (Milano: Polifilo, 1994); Serlio, I Sette Libri dell'Architettura (Milano: Polifilo, 1987). 


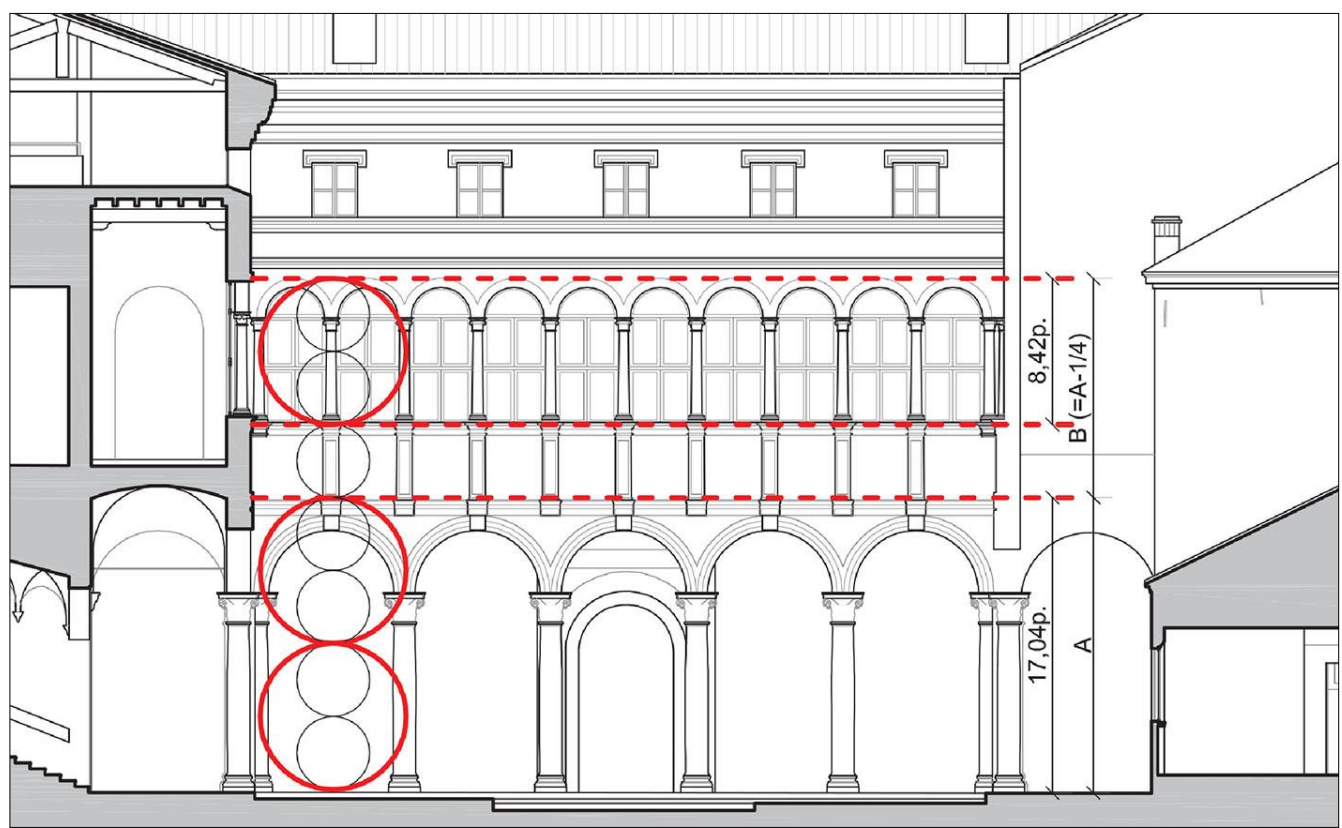

Figure 15. The Elevation Drawing of the Courtyard Shows the Respect of the Theoretical Rule First Suggested by Vitruvius

Source: Metrological and Proportional Survey by the Author.

\section{The History of the Palace's Restorations}

The analyses of Palazzo Costabili considered its restorations to be an integral part of the history of its construction. Of particular importance to this study was the analysis of documents relative to the restoration carried out between 1932 and 1935 , which led to the destruction of a series of walls in the second order of the central courtyard and the creation of a continuous open loggia. One of the results of this study is the entirely new understanding of the principle of construction of the second order, which defines the language of the most novel element of the palace's architecture.

We begin with two pieces of information: photographs taken prior to the restorations, in which the putlog holes in the walls of the infilled openings are evident and perfectly aligned.

The second element is the section: it is necessary to understand the misalignment and notable eccentricity of the upper columns respect to those below them. These columns could not have supported the weight of the roof, considering the important span of the main hall (Figure 16).

To understand what happened in Costabili's courtyard we need to look internally at the pentafora (mullioned window with five lights) illuminating the hall from Via Porta d'Amore (Figure 17). 


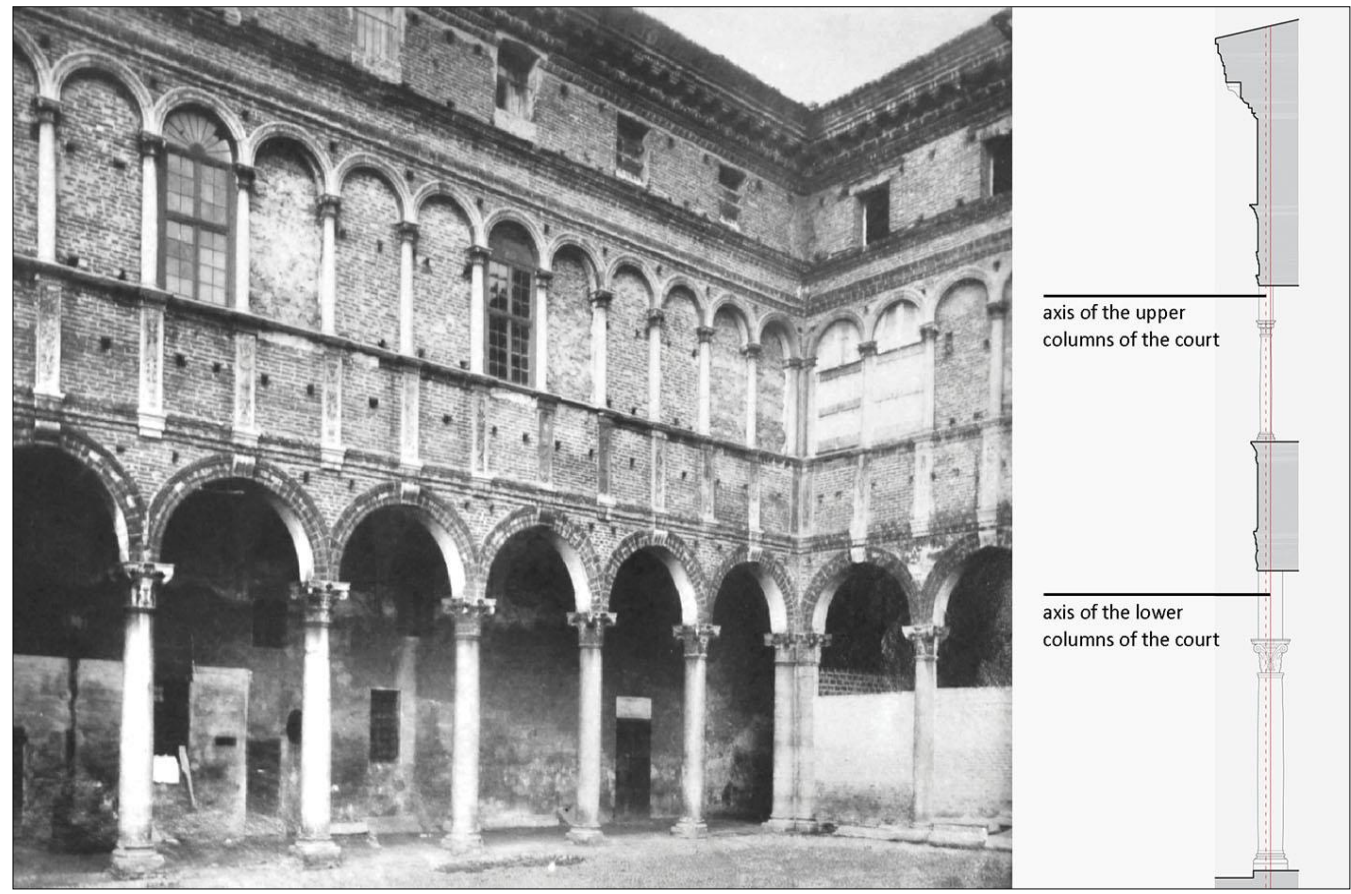

Figure 16. On the Left, a Historical Image of the Court before the Restoration; on the Right, the Cross Section Drawing of the Court with, in Evidence, the Eccentricity of the Upper Columns respected to those below them

Source: Image Preserved in the Archive of the Ministry of Culture in Ravenna; drawing by the Author.

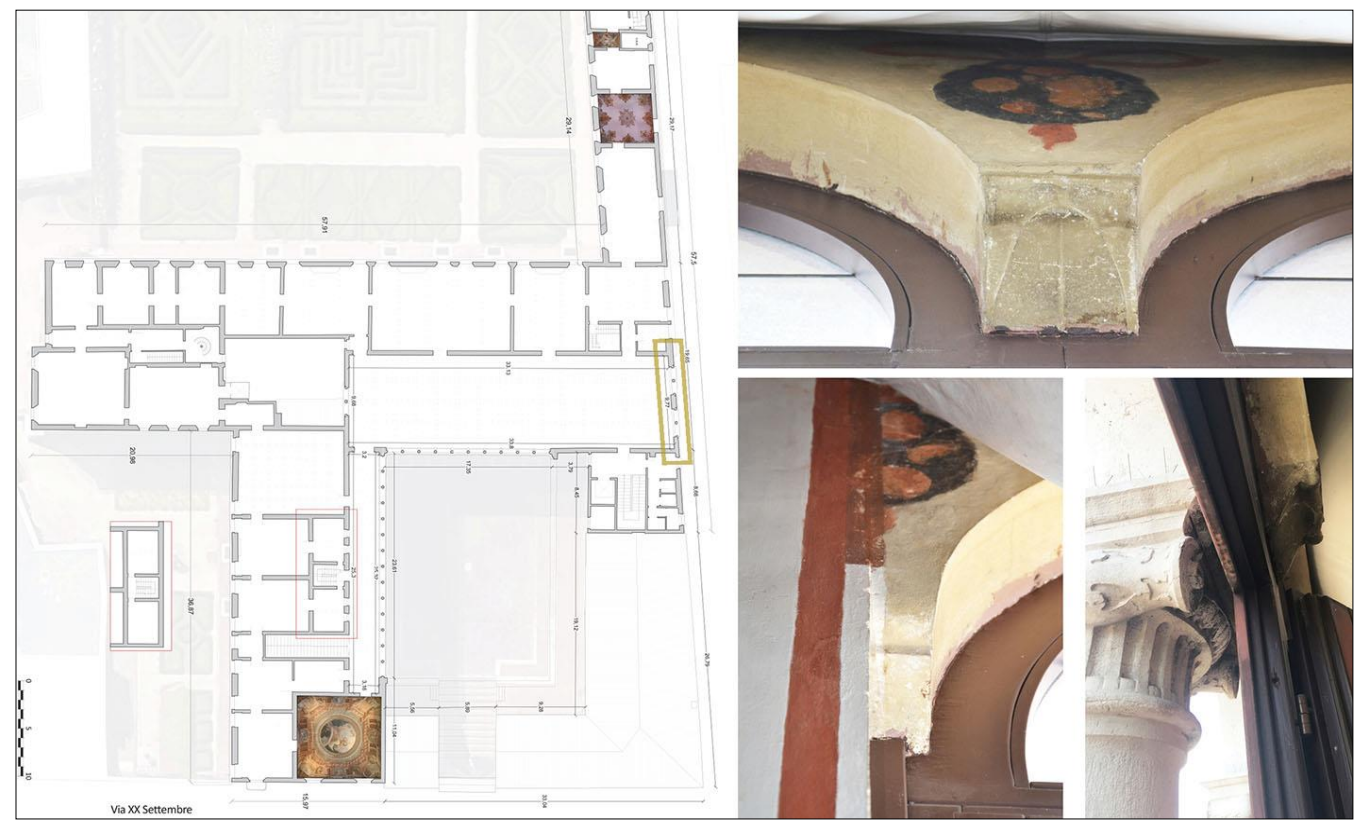

Figure 17. On the Left, the Pentafora on the First Floor (Identified with a Yellow Box); on the Right, the Decorations of the Pentafora

Source: Image Preserved in the Archive of the Ministry of Culture in Ravenna; Survey and Photographs by the Author. 
Here we can note the presence of brackets supporting hanging arches defining the bifora (lancet window), on the inside. There are decorative elements on the walls, such as a festoon of oranges and a garland with a bow that can also be found on the internal wall toward the courtyard. This unprecedented discovery was made possible by varying the saturation of a black and white photograph to expose these decorations (Figure 18).
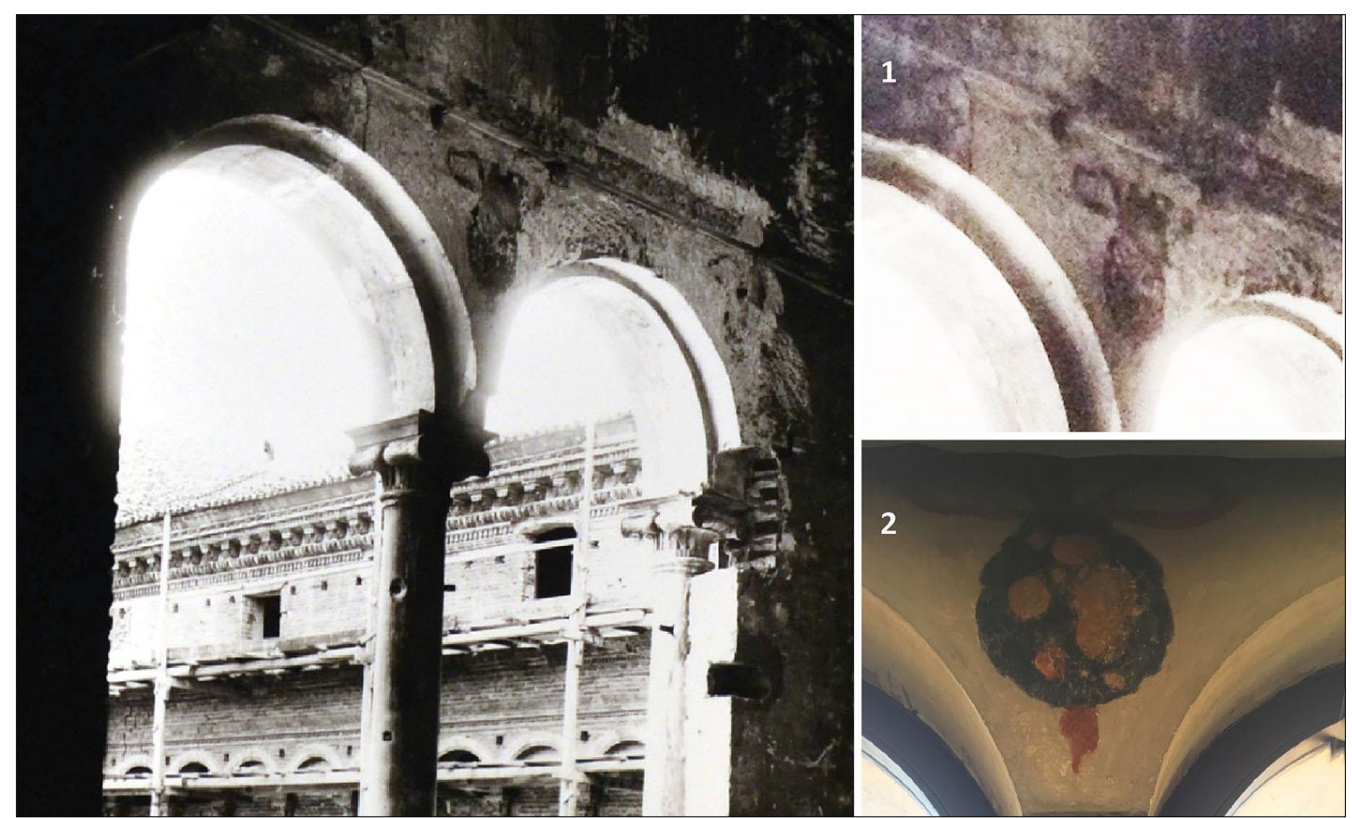

Figure 18. A Historical Photograph that Shows the Decorations Removed by the Restorations (1); These Decorations Were Identical to Those of the Pentafora as the Image on the Right Testifies (2)

Source: Image Preserved in the Archive of the Ministry of Culture in Ravenna; Survey and Photographs by the Author.

Historic photographs taken before the restorations show columns set into the walls, to the point that it is impossible to read one face of the capitals. This begs the question of why a request was made for fully sculpted columns (Figure 19). The study of the survey demonstrated that the idea of resting a marble diaphragm of columns and arches, which could be appreciated in their entirety, against a masonry structure, was possible only by creating a suitable internal bracket, as with the pentafora along Via Porta d'Amore, constructed prior to 1502, before the change of trades on site mentioned above. The comprehension of the architectural definition of the second order of the courtyard certainly represents a spatial invention for Ferrara at the end of the fifteenth century; an invention suitable to the client. While he plainly wished to set his roots in the most ancient part of the city, home to his family, and to use local tradesmen from his quarter, Antonio Costabili intended to create something unprecedented in Ferrara. 

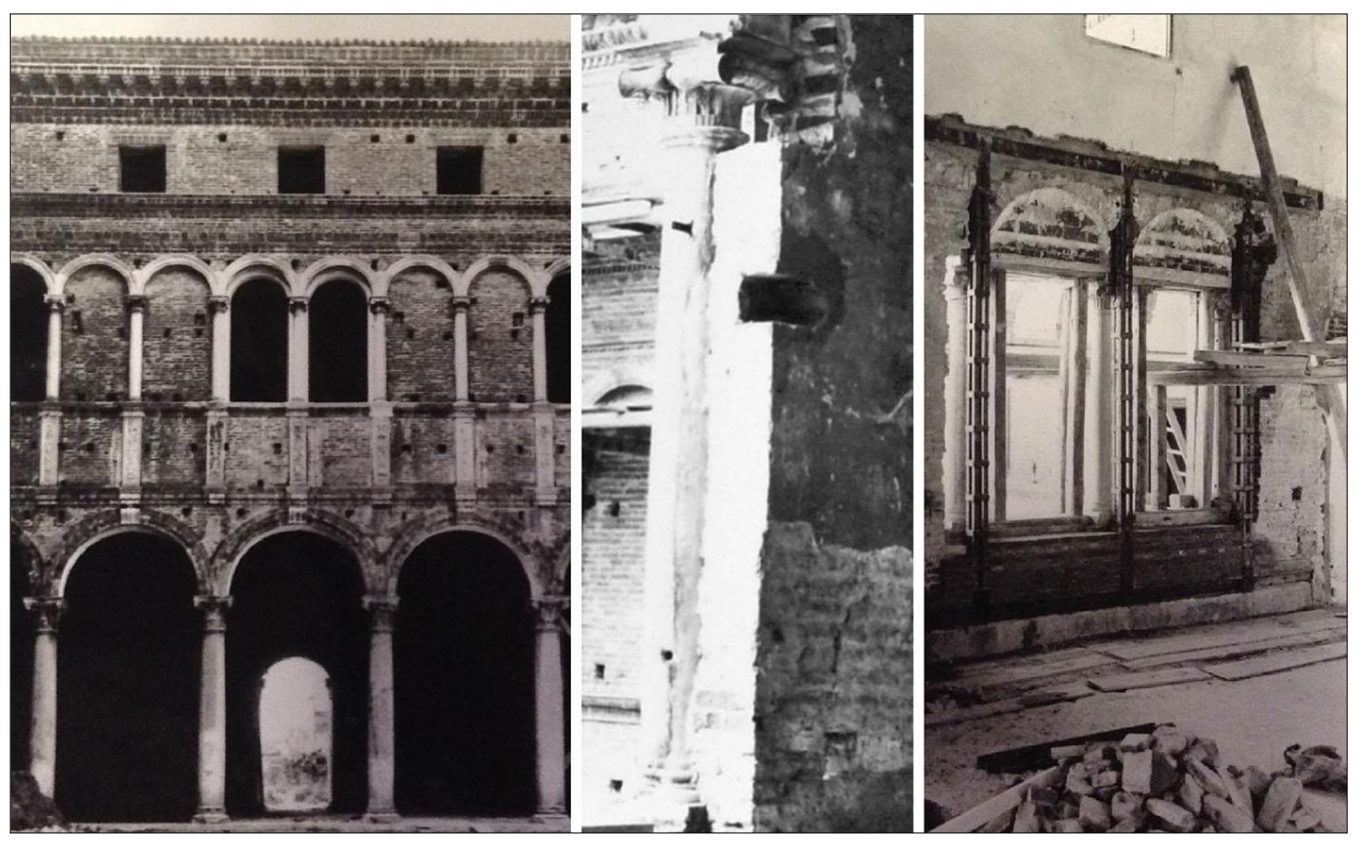

Figure 19. Historical Photographs before the Restorations; the Third Image Shows the Moment when the Restorations Destroyed the Walls behind the Columns Source: Images Preserved in the Archive of the Ministry of Culture in Ravenna.

\section{The Language in Use in Ferrara at the End of the Fifteenth Century}

Broadening our examination, from the detail to the more general events unfolding in Ferrara, and analysing different documents relative to other architectural projects from the late 1400s, the period of construction of Palazzo Costabili, appears to reveal a new language, a way of intending a building as a unified composition, whose constituent elements are part of a reciprocal relationship that responds to a ratio.

An analysis was made of archival documents relative to other projects under construction at the same time as Palazzo Costabili, for example Santa Maria in Vado and the new palaces of the Erculean Addition. New expressions contained in this material speak to a change methods of construction in Ferrara, of an "antique" approach to architecture: "ut dicitur a l'antiga". They also refer to a "ratio" 47 for proportioning columns; they also speak of a large cornice, commonly used at this time, for new buildings: "circumcirca (...) unam cornicem magnam secundum quod nunc communiter fit omnibus pallatiis de novo hedificatis" 48 and "cingimenti de cornise ${ }^{\prime 49}$ on the walls of the nave of the church.

A study of direct and indirect sources revealed a series of building details that demonstrate to what extent Palazzo Costabili can be said to belong to this latefifteenth century language for its reference to antiquity: from the layout of its plan to the proportioning of its courtyard.

47. Franceschini, Artisti a Ferrara in Età Umanistica e Rinascimentale. Testimonianze Archivistiche, 1997, 148.

48. Ivi, 277.

49. Ivi, 292. 
This reference to antiquity was part of humanist culture, permeated the court at Ferrara and inspired the design of Palazzo Costabili, not to mention Antonio Costabili himself.

In addition, we can also consider the particular cultural climate in which Costabili lived and the network of international relations he maintained. On the one hand Milan, the court of Ludovico Sforza where, at the end of the fifteenth century, we find the young Alfonso I d'Este and his brother the archbishop Ippolito d'Este, Antonio Costabili in the role of ambassador of Duke Ercole d'Este and, together with his brother Beltrando, as a member of il Moro's Secret Council. However, we must also consider relations with Rome in the early 1500s, where Alfonso travelled on many occasions and where, following his marriage to Lucrezia Borgia, his brother Ippolito d'Este was named archpriest at St. Peter's. Beltrando Costabili served as ambassador at the Papal Court until 1519.

Alfonso I d'Este is to Antonio Costabili as Ippolito d'Este was to Beltrando Costabili; this synthesis serves to clarify the international ties linking Ferrara with Milan and Rome. These ties are important to a proper understanding of the new language taking form in Ferrara during the period in question (Figure 20); important ties between different courts, with a consequent circulation of ideas and plans.

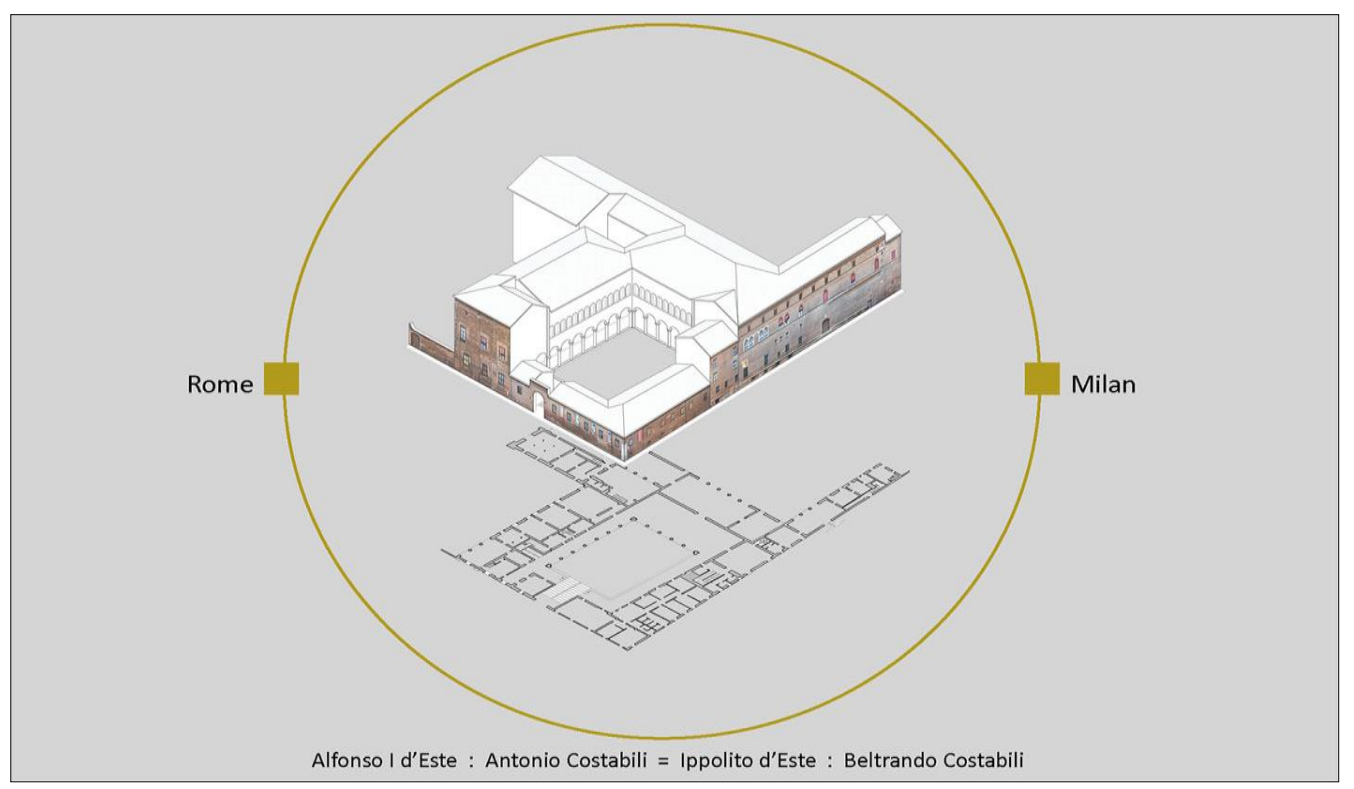

Figure 20. Palazzo Costabili of Ferrara must be related to the Architecture of the Renaissance at the Courts of Milan and Rome

Source: image created by the author.

\section{Conclusions}

This text began with a number of fixed points offered by the vast amount of literature describing the city of Ferrara as an important laboratory of fifteenth and sixteenth century culture. The chronological limits within which we can certainly place the exceptional history of Ferrara span the duration of the Duchy of Ferrara 
(1471) to Devolution (1598), when the city became a province at the margins of the Papal State. There is no doubt that this period witnessed years of florid construction, evidence of broad diplomatic policies with the objective of earning Ferrara an important role in a system of political equilibriums, hard won in the wake of the Peace of Lodi in 1454.

With Ercole I d'Este (1471-1505) and his son Alfonso I (1505-1534), the scale of the interventions realised and planned assumed a relevance that exceeded the importance of purely local questions.

Literary sources have explored and attributed to enlightened clients - the dukes - the capacity to imagine the capital of a Duchy whose cultural importance would expand it beyond its city walls. Numerous buildings were constructed in a very short time. We need only consider the new works tied to the Erculean Addition after 1492, with its noble palaces, churches and a new public square. New buildings were also erected inside the medieval city, such as Palazzo Costabili, and pre-existing churches were expanded, for example San Francesco, Santa Maria in Vado and the Cathedral.

However, if the role of clients, embodied by the D'Este dukes Ercole and Alfonso, has been largely clarified, what contribution was made by so many other figures involved in this process of construction: artisans, entrepreneurs, superintendents or even architects?

This question can be extended to any construction commissioned by the dukes or private citizens.

The research presented begins with a precise methodological assumption: that any general study and any interpretative synthesis cannot avoid an in-depth investigation of specific events, through a rigours ascertainment of facts and a consequent analytical reconstruction of the building process, as stated in the premise.

The particular history of the erection of Palazzo Costabili was reconstructed by overlapping the results of indirect analyses with a specific interpretation of any consideration arising from direct experience. This necessary philological reconstruction was followed by an interpretation of the unresolved parts of the building: from a reading of the plan that revealed previously unidentified preexisting elements, to the comprehension of the small courtyard in the south-east portion of the palace, to the definition of the second order of the courtyard with its alternation of solids and voids, to the proportioning of the elevations of the courtyard to the evident errors or changes made during construction, to the grand stair, to the misalignment between the stair and the corner column to the unfinished elevations. The result of this investigation led to a hypothesis of the phases of the palace's construction and revealed the particular moment of a change in tradesmen in 1502.

The interpretation of the architectural language used in the design of the palace, with a ratio imagined and realised based on precise intentions, was followed by an attempt to place its construction within the architectural culture of its time in order to identify eventual affinities with a growing interest in antiquity.

The analysis of documents relative to coeval projects appears to describe, precisely at the end of the fifteenth century, as Palazzo Costabili was under 
construction, the emergence of a new architectural language that differed from that of the fourteenth and fifteenth centuries; a way of intending a building as a unified composition, whose constituent elements are part of a reciprocal relationship that responds to a ratio.

The question of attribution was raised only at the end of this process of study. It was approached as the conclusion of a rigorous historic reading of this work of architecture, centred on the study of drawings and construction.

Biagio Rossetti, considered by many critics, and in particular Zevi, ${ }^{50}$ to be the architect of Palazzo Costabili, appears incompatible with its refined architecture.

The necessary humanist culture, innate to the informed design of Palazzo Costabili, was clearly possessed by Antonio Costabili. We know that he enjoyed a particular network of personal and cultural relations with Milan in the late-1400s and Rome at the beginning of the 1500s, with Alfonso I and Ippolito d'Este and, in particular, with his own brother Beltrando.

The palace can be said to resemble a choral realisation of a precise project, in which the client's intentions take form through a series of interventions carried out by teams of tradesmen, a succession of masons in only a few years, stoneworkers, carpenters and painters, all coordinated by a Ducal engineer or expert mason, such as Tristano. Yet, its architecture is decided by the skill and desire of a humanist client, in this case Antonio Costabili.

Only Costabili's Studia humanitatis, an education described in the first chapter, allows us to understand the proportions between the different architectural parts and to justify the cultured language employed at Palazzo Costabili, a true example of a new art of building that developed in Ferrara between the latefifteenth-early sixteenth century.

\section{Bibliography}

Agnelli, G. Il Palazzo di Lodovico il Moro in Ferrara [The Palace of Lodovico il Moro in Ferrara.] Ferrara: Zuffi, 1902.

Alberti, L. B. L'Architettura [Architecture.] Milano: Il Polifilo, 1966, 808.

Alfieri, N. Il Palazzo Detto di Ludovico il Moro [The Palace Known as Ludovico il Moro.] Rovigo: STER, 1955.

Avventi, F. Il Servitore di Piazza: Guida per Ferrara [The Square Servant: Guide for Ferrara.] Ferrara: Pomatelli, 1883, 153-155.

Baretta, S. "Il Palazzo di Ludovico il Moro." [The Palace of Ludovico il Moro.] In F. D. Bollettino della Ferrariae Decus. Ferrara: Este Edition, 1998, 7-22.

Boari, A. "Bramante, Rossetti e il Palazzo d Ludovico il Moro Bramante" [Rossetti and the Palace of Ludovico il Moro.] In Gazzetta Ferrarese. Ferrara: Officina della Gazzetta, 1914.

Bruschi, A. Introduzione alla Storia dell'Architettura. Considerazioni sul Metodo e sulla Storia degli Studi [Introduction to the History of Architecture. Considerations on the Method and History of Studies.] Città di Castello: Mondadori Università. 2009.

50. Zevi, Biagio Rossetti Architetto Ferrarese il Primo Urbanista Moderno Europeo, 1960, 320-324 
Burckhardt, J. Storia del Rinascimento in Italia [History of the Renaissance in Italy.] Torino: N. Aragno, 2006, 324.

Calcagnini, C. Opera Aliquot. Basilea, 1544, 436.

Cittadella, N. Indice Manuale delle Cose Più Rimarcabili in Pittura, Scultura, Architettura della Città e Borhi di Ferrara [Manual Index of the Most Remarkable Things in Painting, Sculpture, Architecture of the City and Boros of Ferrara.] Ferrara, 1844, 6769.

Calzecchi Onesti, C. "Il Palazzo detto di Lodovico il Moro, Cenni Storici e Critici e Relazione sui Restauri" [The Palace Known as Lodovico il Moro, Historical and Critical Notes and Report on Restorations.] In The Spina Museum in Ferrara. Edited by S. Aurigemma. Ferrara: Municipality of Ferrara, 1936.

Di Francesco, C. "Palazzo di Ludovico il Moro (Note Storiche)" [The Palace of Ludovico il Moro (Historical Notes).] In Giardini e Palazzi Rinascimentali di Ferrara. Sviluppo Urbanistico Moderno. Ferrara: Atti del Corso di Aggiornamento, 1996, 194-199.

Fedozzi, I. and B. Guelfi. "Nuovi Documenti e Ipotesi di Lavoro su un Committente Ferrarese nell'Età di Alfonso I: il Conte Costabili" [New Documents and Working Hypotheses on a Client from Ferrara in the Age of Alfonso I: Count Costabili.] In Il Camerino delle pitture di Alfonso. Padova: Bertoncello Arti Grafiche, 2007, 65-76.

Franceschini, A. Artisti a Ferrara in Età Umanistica e Rinascimentale. Testimonianze Archivistiche [Artists in Ferrara in the Humanistic and Renaissance Age. Archive Testimonies.] Ferrara-Roma: Gabriele Corbo Editore, 1997.

Frizzi, A. Guida del Forestiere per la Città di Ferrara del Dott [Guide of the Stranger for the City of Ferrara.] Ferrara, 1787, 135-136.

Giovannoni, G. "Ferrara. The Palace of Ludovico il Moro" [Ferrara. Il Palazzo di Ludovico il Moro.] In Rassegna di Architettura, no. 8-9. Milano: Graphic Institute, 1936, XXIV-XXVI.

Guarini, M. A. Compendio Historico dell'Origine, Accrescimento e Prerogative delle Chiese, e Luoghi pii della Città e Diocesi di Ferrara [Historical Overview of the Origin, Growth and Prerogatives of Churches, and Pious Places in the City and Diocese of Ferrara.] Ferrara, 1621, 294-295.

Marcianò, A. F. L'Età di Biagio Rossetti. Rinascimenti di Casa d'Este [The Age of Biagio Rossetti. Renaissance of the House of Este.] Ferrara-Roma: Gabriele Corbo Editore, 1991, 115-126.

Martini, F. dG. Trattati di Architettura, Ingegneria e Arte Militare [Treaties of Architecture, Engineering and Military Art.] Milano: Il Polifilo, 1967, 86.

Nardelli, C. and M. Tassotti. L'Addizione di Borso: Analisi dell'Edilizia Storica sull'Asse Quattrocentesco di via Ghiara: Individuazione del Limite Fisiologico di Trasformazione degli Organismi Edilizi Finalizzata alla Loro Conservazione [The Addition of Borso: Analysis of Historical Buildings on the Fifteenth-Century Axis of Via Ghiara: Identification of the Physiological Limit of Transformation of Building Bodies Aimed at their Conservation.] Master Degree Thesis. University of Ferrara, 2009.

Padovani, G. "Biagio Rossetti e il Palazzo di Antonio Costabili" [Biagio Rossetti and the Palace of Antonio Costabili.] In Corriere Padano. Ferrara: Soc. An. Emiliana, 1930. . Architetti Ferraresi [Ferrara Architects.] Rovigo: STER, 1955, 82.

Pattanaro, A. "Garafolo e Cesariano in Palazzo Costabili a Ferrara" [Garafolo and Cesariano in the Costabili Palace in Ferrara.] In Prospettiva. Firenze: Centro Di, 1994, 97-110.

. "Il Restauro di un Importante Affresco Rinascimentale Apre Nuove Prospettive Storiche" [The Restoration of an Important Renaissance Fresco Opens up New 
Historical Perspectives.] In Ferrara voci di una città. Ferrara: Cassa di Risparmio di Ferrara Foundation, 2009, 39-43.

Petrucci, F. “Antonio Costabili." In Biographical Dictionary of Italians. Roma: Institute of the Italian Encyclopedia, 1984, 257-260.

Piconi Aprato, G. "Il Palazzo Detto di Lodovico il Moro in Ferrara" [The Palace Known of Lodovico il Moro in Ferrara.] In Ferrarese Museums, Annual Bulletin. Firenze: Centro Di, 1972, 117-128.

Reggiani, G. I Portali di Ferrara nell'Arte [The portals of Ferrara in art.] Ferrara: Tipografia Taddei-Soati, 1907, 102-103.

. "Bramante, Rossetti e il Palazzo d Ludovico il Moro" [Bramante, Rossetti and the Palace of Ludovico il Moro.] In Gazzetta Ferrarese. Ferrara: Officina della Gazzetta, 11 Giugno 1914.

Righini, E. Quel che Resta di Ferrara Antica [What Remains of Ancient Ferrara.] Ferrara: Estense Libro, 1911, 55-98.

. "Bramante, Rossetti e il Palazzo d Ludovico il Moro" [Bramante, Rossetti and the the Palace of Ludovico il Moro.] In Gazzetta Ferrarese. Ferrara: Officina della Gazzetta, 1914.

Sambin de Norcen, M. T. "Osservazioni sui Palazzi (1490-1503)" [Observations on the Buildings (1490-1503).] In Grande così Quanto Forse Ignorato: Omaggio a Biagio Rossetti. Ferrara: Grafiche Turato Edizioni, 2018, 49-66.

Scalabrini, G. A. Momorie Istoriche delle Chiese di Ferrara e de' Borghi [Historical Scenes from the Churches of Ferrara.] Ferrara, 1773, 288-289.

Serlio, S. I Sette Libri dell'Architettura [The Seven Books of Architecture.] Milano: Polifilo, 1987. . Architettura Civile [Civil Architecture.] Milano: Polifilo, 1994.

Varese, R. "Il Palazzo di Costabili (Detto di Ludovico il Moro)" [The Palace of Costabili (Known of Ludovico il Moro).] In Spina. Museo Archeologico Nazionale di Ferrara. Bologna: Calderini, I-XXV.

Vitruvio Pollione, M. De Architectura. Milano: Polifilo, 1997, 571.

Zaccarini, D. "Ferrara. Palazzo di Ludovico il Moro" [The Palace of Ludovico il Moro.] In Architettura e arti decorative Ferrara. Milano-Roma: Bestetti and Tumminelli, 1922, 304-305.

Zevi, B. Biagio Rossetti Architetto Ferrarese il Primo Urbanista Moderno Europeo [Biagio Rossetti, Ferrara Architect, the First European Modern Urban Planner.] Torino: Einaudi, 1960, 320-324. 


\title{
Transformation of Cinema Buildings and Spaces in Nicosia: Early-Mid 20 ${ }^{\text {th }}$ Century Heritage
}

\author{
By Aliye Menteş ${ }^{*} \&$ Valentina Donà ${ }^{ \pm}$
}

\begin{abstract}
Cinemas emerged as a new and genuine expression of culture at the beginning of the 20th century. In the 1920s cinema buildings became important for developing city life and especially as a social public space for entertainment. The period of great success of cinemas was inevitably destined to fade with the arrival of TV. However, this period left behind interesting architectural heritage. On the other hand, the "box of dreams", the cinema industry, is a suggestive media contributing in defining other aspects of popular culture in a period of hectic changes and progress. The scope of this paper aims to investigate this specific building type, cinemas, within the context of modern heritage value in northern Cyprus. The purpose is to raise awareness on significance of cinema buildings thus to foster their protection and enhancement. The study also aims to investigate the historical relation of these buildings to their environments and neighborhoods as well as their transformed current situations. Some buildings were replaced with new ones, some were abandoned, and some others were converted into different uses. These transformed situations are results of changing economic, socio-cultural life styles and changing morphology of the cities. This paper aims also to stress the role of Cypriot architects and architecture in the international panorama within the Mediterranean area, in a peculiar multicultural context. Common features with other countries and local characteristics of the selected buildings are detected and analysed. Architectural qualities and solutions are studied to understand the reflections of the studied period. This study follows a qualitative research approach. The key discussions are made through investigating the cinema buildings and spaces in Nicosia, Northern Cyprus, as a case study method. This research investigates these buildings and spaces through historical archives, photographic surveys and producing maps for showing the location of these within the historic Walled City of Nicosia and its close surrounding. This stage provides significant data about their historic conditions and surroundings and comparisons with today's current situations. In addition, interviews with local residents who used these cinemas in those periods are also carried out to support historical information and highlight the socio-cultural and economic understanding of those days.
\end{abstract}

Keywords: Modern heritage, Cinema buildings, Open air cinema, Transformation, Nicosia

\section{Introduction}

In the last two decades, the lack of identification and documentation of lessrepresented categories of heritage becomes evident. UNESCO and ICOMOS becomes aware of the vulnerability of Modern Heritage Architecture of the $19^{\text {th }}$ and $20^{\text {th }}$ centuries, due to weak legal protection and low appreciation among the general public. In 2001 UNESCO's World Heritage Centre, the International Council on Monuments and Sites (ICOMOS) and the Working Party on the

*Assistant Professor, European University of Lefke, Cyprus.

\pm Assistant Professor, Girne American University, Cyprus. 
Documentation and Conservation of buildings, sites and neighbourhoods of the Modern Movement (DOCOMOMO) started a joint programme for the identification, documentation and promotion of the built heritage of the modern era.

An important document was produced by UNESCO, Identification and Documentation of Modern Heritage (2003), where Francesco Bandarin summarised the situation regarding to Modern Heritage as

'...due to rapid socio-economic changes in society demanding a different functional use, a poor understanding of the significance of these properties and sites plays an equally important role. In addition to traditional heritage categories, such as archaeological sites and monuments, also modern properties and sites need to be considered that are worthy of preservation and transmission to future generations for reasons of cultural identity in relation to aspects of continuity and change. In order to gain better understanding, raise public awareness and promote inscription of this category of heritage, study and evaluation of possibilities, establishment of criteria and selection of properties and sites is needed...,

Francesco Bandarin Director, UNESCO World Heritage Centre

Following this statement and facing similar problems in the context of the northern part of Cyprus, this paper aims to address the modern architectural heritage in Cyprus. The island has a long and rich history, thus valuable cultural heritage spanning from the Neolithic age to Modern times, passing through the signs left by Phoenicians, Persians, Greeks, Anatolians, Romans, Byzantines, Crusaders, Lusignans, Venetians, Genoese, Ottomans and British to mention the main ones. Currently valuable cultural heritage is still not appreciated enough and not protected extensively, even though many efforts have been spent through international and bi-communal associations and administrations. There is lack of conservation and protection rules and regulations towards more recent heritage. In this respect, the attention given to modern heritage is very little. Only recently, better understanding for their protection is received from architecture and heritage professionals and academics. ${ }^{2}$ It is important to remark that many modern artefacts are currently under threat because of changing life standards and buildings becoming out of use for different reasons. Furthermore, due to private ownership, public administrations are not interested to spend resources or to take initiatives for their protection. It is urgent to raise awareness on valuable modern heritage architecture, which has already lost a number of significant buildings and continues to disappear because of neglect and endangered conditions. The risk is that some good examples of $20^{\text {th }}$ Century modern architecture might be lost together with a part of the recent memory of the Cypriot society.

Cinemas emerged as a new and genuine expression of the culture at the beginning of the $20^{\text {th }}$ century. In the 1920 s cinema buildings became important for

1. O. Ron Van and S. Haraguchi, Identification and Documentation of Modern Heritage (Paris: UNESCO World Heritage Centre, 2003), 3.

2. Ş. Ö. Hoşkara and N. Doratli, A Critical Evaluation of the Issue of "Conservation of the Cultural Heritage" in North Cyprus (Ankara: ICANAS 38, 2007), 849-872. 
developing city life and especially as a social public space for entertainment. The period of great success of cinemas was inevitably destined to fade with the arrival of TV. However, this period left behind interesting architectural heritage. On the other hand, the "box of dreams", the cinema industry, is a suggestive media contributing in defining other aspects of popular culture in a period of hectic changes and progress. In the beginning of the $20^{\text {th }}$ century, indoor cinema buildings and outdoor cinema spaces were also emerged in Cyprus. In the earlymid $20^{\text {th }}$ century, cinema buildings and spaces were frequently used by the Cypriot community and there are many elaborate cinema buildings as modern heritage of this era.

Within the context of Cyprus, there are only a few studies concerning modern architecture as heritage, ${ }^{3}$ yet $20^{\text {th }}$ century cinema buildings are mentioned only in one study as part of modern heritage. ${ }^{4}$ In addition to this, a Turkish book by a journalist involves historical information of the cinema sector and interviews with related people, memories about cinemas in Cyprus. ${ }^{5}$ However, so far, there has been no research undertaken regarding to cinema buildings and, no academic publications exist for creating inventories of this type of building along with combining the intangible assets of the cinemagoing experience.

The scope of this paper is to investigate the specific building type, cinema halls, within the context of modern heritage value in northern Cyprus. The purpose is to raise awareness on significance of cinema buildings thus to foster its protection and enhancement. The study also aims to investigate the historical relation of these buildings to their environments and neighborhoods as well as their transformed current situations. Some buildings were replaced with new ones, some were abandoned, and some others were converted into different uses. These transformed situations are results of changing economic, socio-cultural life styles and changing morphology of the cities. This paper aims also to stress the role of Cypriot architects and architecture in the international panorama in the Mediterranean area, in a peculiar multicultural context. Common features with other countries and local characteristics of the selected buildings are detected and analysed. Architectural qualities and solutions are studied to understand the reflections of the studied period.

3. E. Oze et al. Cyprus 100 [Most] Important Buildings, Sites and Neighbourhood (Nicosia: Docomomo Cyprus, 2014), 2-11; P. Pyla and P. Phokaides, "Virtual Tour - Architecture and Modernity in Cyprus," Eahn newsletter European Architectural History Network 2, no. 09 (2009): 36-49; M. Kiessel and A. Tozan, "The Passenger Steamer and Cypriot Modern," Prostor - A Scholarly Journal of Architecture and Urban Planning 19, no. 1 (2011): 218-222.

4. C. Georghiou, The Architecture of the Cypriots during British Rule 1878-1960 (Nicosia: En Tipis Publications, 2018).

5. A. Tolgay, Kibris 'in Orta Yeri Sinema (Lefkoşa: Okman Printing Ltd., 2016). 

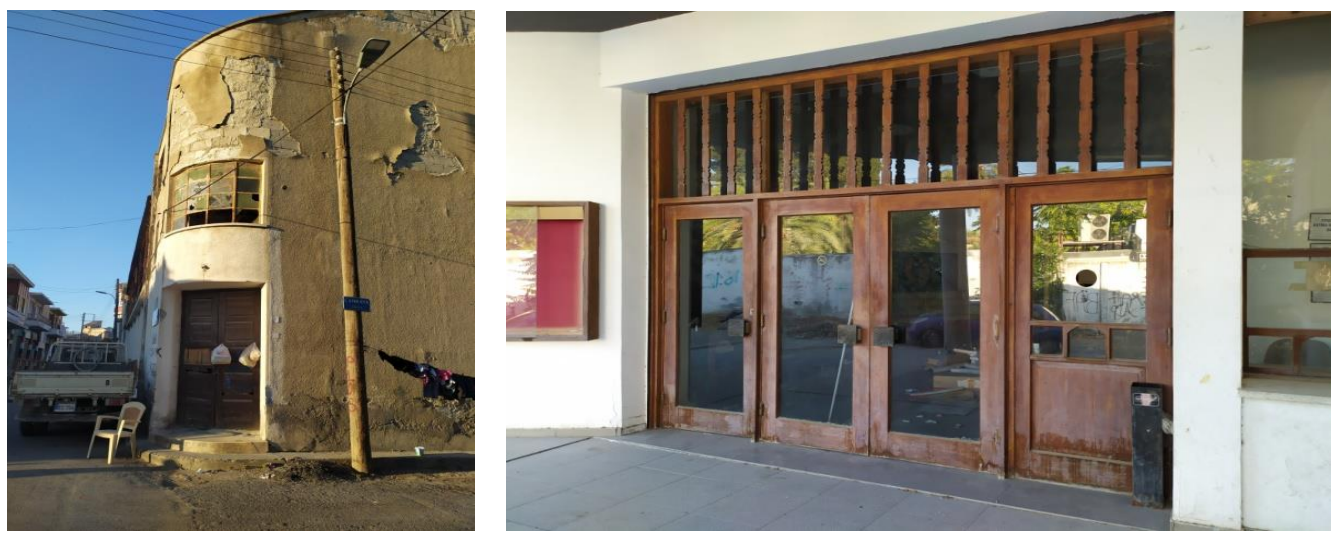

Figures 1-2. Decay of Zafer Cinema and State of Abandoned Misirlizade Cinema in Nicosia

Source: A. Menteş and V. Donà, 2019.

\section{Methodology}

This research is undertaken based on literature review, surveying of buildings on site, carrying out interviews and questionnaires with local people. The literature review involves (1) examining modern architecture within the context of Cyprus and Nicosia in specific, describing the important building typology of the cinema halls (2) examining architectural similarities between cinema buildings throughout Eastern Mediterranean countries, (3) examining the examples of cinema buildings built in Cyprus between the 20s and the 60s, before the division of the Island, and (4) examining indoor (closed cinema buildings) and outdoor (open air cinema spaces) cinemas built in the northern part of Nicosia. More emphasis is given on those buildings that are still standing (Figures 1-2).

The key discussions are made through investigating the cinema buildings and spaces in Nicosia, northern Cyprus, as a case study method. This research investigates these buildings and spaces first through historical archives, photographic surveys and producing a map for showing the location of these buildings and spaces within historic Walled City of Nicosia and its close surrounding. This stage provides significant data about their presence within the urban context. Besides literature review a qualitative research approach is followed in this research. Questionnaires and interviews with local residents, who used these cinemas in 1950s, 1960s and 1970s were carried out to support historical information and highlight the socio-cultural and economic understanding of those days. Among the limitations of the research, old photos and architectural drawings are very few as no archives concerning these buildings existed.

The structure of this paper follows the abovementioned outline of the literature review. The last part of the paper focuses on the cinema going experience as it was a significant cultural context of Nicosia. As a conclusion some suggestions are provided for the protection of these endangered buildings. 


\section{Modern Heritage in Cyprus: General Characteristics}

Concerning Cyprus, it should be mentioned that the Island was part of the Ottoman Empire since 1571 and from 1878 it was under the British Rule until 1960. During the Colonial period, the administrative and valuable buildings were built by foreign architects or engineers, mainly British. At that time, there were not Cypriot professionals, but some master-builders or practical architects, called mastores, ${ }^{6}$ were involved in the constructions of traditional houses or public buildings like churches or schools. They had good knowledge of traditional building techniques and some sort of understanding about design. They used to move throughout the Island due to different work and construction sites. In some cases, they further travelled to Southern Anatolia to Adana or Mersin.

Between the turning point of $19^{\text {th }}$ Century to $20^{\text {th }}$ Century, a number of young Cypriots started to travel abroad to get their higher education. There is no record, found yet, of the first Cypriot architect or engineer during the British period, however, it is known that in 1904, Theodoros Photiades received his Diploma in Engineering from the Metsovio Polytechnic in Athens. After his graduation, he moved first to Alexandria in Egypt to start his career, where he got in touch with its cosmopolite environment during the Belle Époque, with influences of European culture besides the Arabic one. In 1920, he returned permanently to Cyprus, taking his multicultural background with him. ${ }^{7}$ As similar to Photiades, other generations of young Cypriots moved abroad to get their diplomas or to start their professional careers in Greece or Turkey, because of the familiarity to the language, but also in Egypt, Lebanon, United Kingdom and even Italy, Germany or France. Between the end of the 1980s and beginning of the 1990s, a number of Universities with architecture faculties started to be established in the Island. This was a new opportunity for Cypriots to study in their country.

Between 1920s and 1970s, different architectural languages can be detected. ${ }^{8}$ It is possible to list the British Colonial style, that is mainly a rational version of local vernacular architecture, ${ }^{9}$ with use of local material and with light ornamentation, often applying loggias, balconies, verandas or courtyard in order to extend the inner space outdoor (Figure 3). Then, a mixed style combining characteristics of British Colonial and typical elements of early modernism (as it has been developed in the centre of Europe between the two World Wars) can be seen. The general features include motifs taken from the passenger steamer, like portholes windows, balconies as ship decks with linear metal handrails (Figure 4), rational organization of the interior ${ }^{10}$. Furthermore, the emphasis on the corner of

6. Georghiou, The architecture of the Cypriots during British rule 1878-1960, 2018, 23.

7. Ibid.

8. S. Fereos and P. Phokaides, "Architecture in Cyprus between the 1930s and 1970s." Docomomo 35 (2006): 15-19.

9. Pyla and Phokaides, "Virtual Tour - Architecture and Modernity in Cyprus," 2009, 36-47. 218-222.

10. Kiessel and Tozan, "The Passenger Steamer and Cypriot Modernism 1930-1970," 2011, 
the buildings facing an intersection, remarked by special decorations or highlighted with special architectural elements are visible characteristics. ${ }^{11}$

During the 1950s and 1960s it is possible to notice a transition to a more mature modernist influence due to new generation of architects, who applied the use of concrete structure, with more brave experiments in terms of construction and design (Figure 5). They also brought some elements typical of International Style such as wide span of glass, concrete canopies, cantilevers, more dynamic and interconnected interior spaces.

Important Cypriot architects of the 1950s and 1960s include; Ahmet Vural Bahaeddin, Abdullah Onar, Ayer Kaşif, Diomides Kythreotis, Hakki Atun, Neoptolemos Michaelides, Panayiotis Stavrinides, Polyvios Michaelides. At that time the Island was not divided and the architects and engineers of the Greek and Turkish communities used to know each other well and collaborated in many professional endowers. $^{12}$
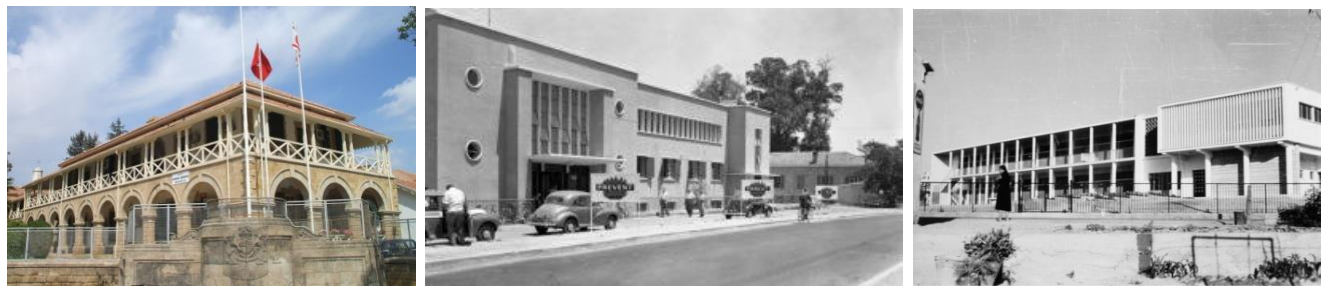

Figures 3-5. Modern Architectural Languages in Cyprus: Law Courts Building, 1901, Press and Information Office Building 1953-55, Lykavytos Elementary School, 1955-57, in Nicosia

Source: http://www.t-vine.com/turkish-cypriot-rule-of-law-legality-in-illegality/; https://cyprusmail.com/old/2013/06/02/colonialism-in-stone/; P. Phokaides, "Virtual Tour - Architecture and Modernity in Cyprus," EAHN Newsletter [Newsletter of the European Architectural Historians Network] no. 2/09 (2009).

\section{Cinemas as New Type of Building in the $20^{\text {th }}$ Century}

In the field of Modern Heritage a special role is played by cinema buildings. After the advent of moving pictures, at the end of $19^{\text {th }}$ Century, no special spaces were designed for showing movies. First itinerant marquee (travelling circus type tent structure) was used for this purpose, then, mainly in USA, nickelodeon started to spread (Figures 6-8). These spaces were early motion-picture theatres that flourished from about 1905 to $1915,{ }^{13}$ usually set up in converted storefronts, where a film or a variety show could be seen, usually for the admission price of one nickel (nickel, the name of the U.S. five-cent coin and odeon that is a Greek

11. M. Kiessel, "Art Deco Architecture in Cyprus from the 1930s to the 1950s." Prostor - A Scholarly Journal of Architecture and Urban Planning 20, no. 1 (2012): 172-185.

12. Oze et al., Cyprus 100 [Most] Important Buildings, Sites and Neighbourhood, 2014.

13. Nickelodeon (Movie Theatre), Wikipedia [Accessed 30 June 2019.] Retrieved from: https://en.wikipedia.org/wiki/Nickelodeon_(movie_theater). 
term for a building for musical performances. ${ }^{14}$ The nickelodeon became popular between working and middle class.
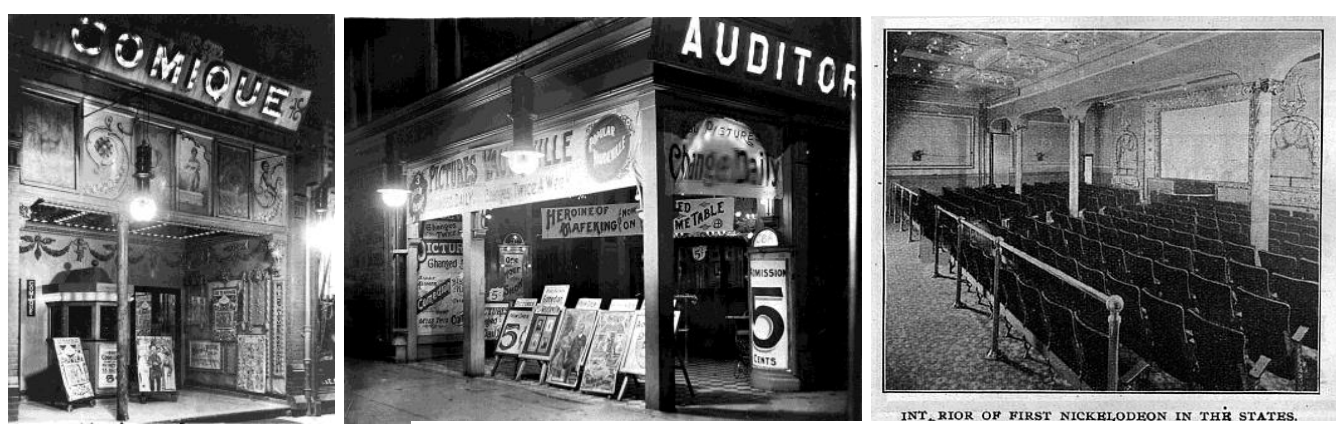

Figures 6-8. Examples of a Nickelodeon Theatre in Toronto, Ontario, Canada, around 1910; A Nickelodeon in 1910; Pittsburg Nickelodeon, Pittsburg, Pennsylvania, USA, 1905

Source:

https://en.wikipedia.org/wiki/Nickelodeon_(movie_theater)\#/media/File:ComiqueTheatre.jpg; http://www.marcopucci.it/i-nickelodeon/.

When longer films started to be popular and more comfortable venues were required, these places were then abandoned. Since the 1920 s the so called "movie palaces"15 started to be built replacing smaller venues (Figures 9-11).
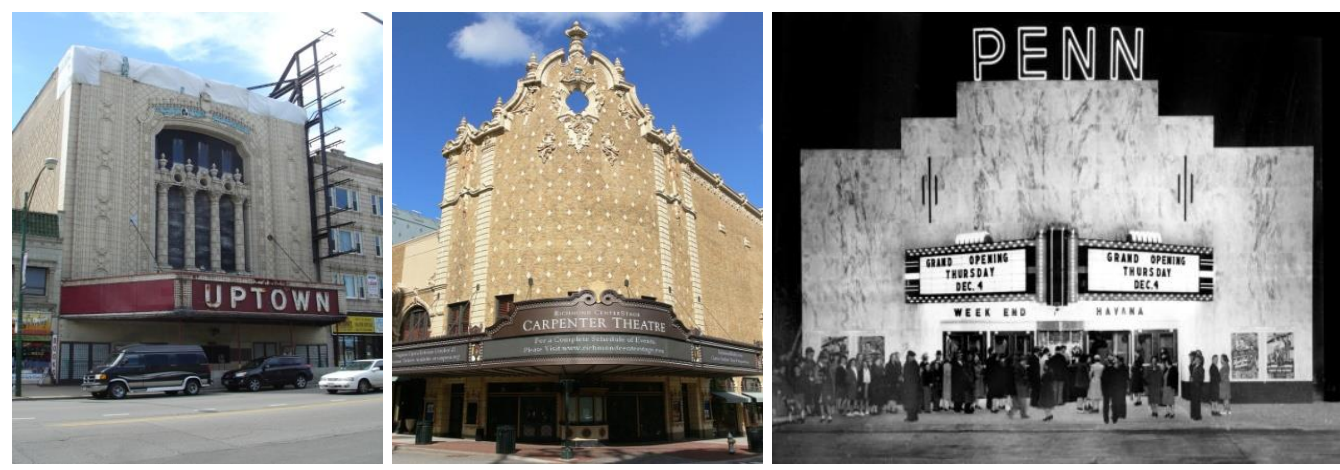

Figures 9-11. Examples of Movie Palaces: Uptown Theatre in Chicago. Illinois, USA, 1925; Carpenter Theatre, Richmond, Virginia, USA, 1927-28; Penn Theatre, Plymouth, Michigan, USA, Opened in 1941

Source: $\quad$ https://en.m.wikipedia.org/wiki/File:Chicago,_Illinois_Uptown_Theater1.jpg; https://en.wiktionary.org/wiki/movie_palace\#/media/File:Carpenter_Theatre_Richmond_Va.JPG; http://www.penntheatre.com/history.html.

In other contests, first improvised spaces were arranged to host movie screenings, such as rooms in town halls or other public buildings. Especially theatres started to be adapted for the new use until the growth of film industry.

14. Nickelodeon, Liberal Dictionary [Accessed 30 June 2019.] Retrieved from: https://www. liberaldictionary.com/nickelodeonnickelodeon/.

15. Movie Palace, Wikipedia. [Accessed 24 July 2019.] Retrieved from: https://en.wikipedia. org/wiki/Movie_palace. 
The diffusion of cinema going experience brought to the construction of buildings exclusively dedicated to the projection of movies.

It is interesting to note that the movie watching experience is often directly affected by the space where it is enjoyed. The space and the presence of people blended in with the projection to create a unique feeling. Especially in the first experiences in the itinerant marquees or in the town halls temporary use rooms, the memory of the space was transmitted with an intensity that was not inferior to the one of the projected story. In the memory of the audience, the room lived more for the life that pulsated inside it rather than for the images come to life on the screen. The spectator lost the boundaries of the individual ego and was led to a natural fusion in a collective ego. Everywhere the light that lighted up in the dark transmitted the sense of openness and conquest of a new world. A world that is more real than true, also proposing itself as a privileged access key to future and modernity. ${ }^{16}$

\section{Closed Cinema Buildings and Open Air Cinema Spaces: Significance as Modern Heritage in the Eastern Mediterranean and Cyprus Context}

Taking into account the value of cinema buildings, two kinds of aspects should be considered.

Tangible aspects concern architecture and urban context, whereas intangible aspects concern socio-cultural significance. ${ }^{17}$ Those buildings started to play the role of modern landmarks in the urban fabric, both for their architectural form and characteristics and for their location. In addition to this, outdoor and indoor cinema spaces played an urban role on the further development of the local urban morphology. They are historical documents witnessing social and economic data related to a specific period. They are part of recent heritage and, in the best cases, interesting examples of architecture or structural engineering. Their design, details and applied materials bear witness to the way of designing and constructing of that specific temporal and geographical context. On the other hand, cinema buildings are rooted in the common memory of people and are part of the urban memory. They used to represent a valid source of entertainment in Cyprus in periods with little options especially if wars and unstable political and economic situations are considered. Lastly, cinemas had definitely an important role of meeting and socialising within the urban and suburban communities.

Looking at the Eastern Mediterranean context, ${ }^{18}$ it is easy to spot similarities in the features of cinema buildings, especially for those countries that used to have more or less closely knit cultural, economic or professional relations. To mention a

16. G. P. Brunetta, "Sala cinematografica," in Enciclopedia del Cinema Treccani. [Accessed 28 June 2019.] Retrieved from: http://www.treccani.it/enciclopedia/sala-cinematografica_\%28 Enciclopedia-del-Cinema\%29/.

17. P. Ercole, D. T. Gennari, S. Dibeltulo and L. V. Vijver, "Cinema Heritage in Europe: Preserving and Sharing Culture by Engaging with Film Exhibition and Audiences," Alphaville Journal of Film and Screen Media 11 (2016): 1-12.

18. J. F. Lejeune and M. Sabatino, "North versus South - Introduction," in Modern Architecture and the Mediterranean (London-New York: Routledge, 2010): 1-12. 
few: Egypt, Greece, Turkey, Italy. It is possible to pick some cases from cities like Cairo, Athens, Istanbul, Izmir and Rome.

Some examples from cinemas in Cairo in 1930s and 1940s can show a big emphasis on the corner of the building, often at the crossing of important streets. Architectural elements, huge billboards, signs or special decoration usually defined the entrance placed in the corner. Canopies, cantilevered elements, light bulbs, columns are displayed to catch the attention of the citizens (and eventually spectators). Important cinema buildings in Cairo include Diana Palace Cinema (1930s) (Figure 12), MGM Cinema (1940s) (Figure 13), Odeon Cinema (1940s), Cinema Radio e Rivoli Cinema (1948) (Figure 14) among the others. ${ }^{19}$
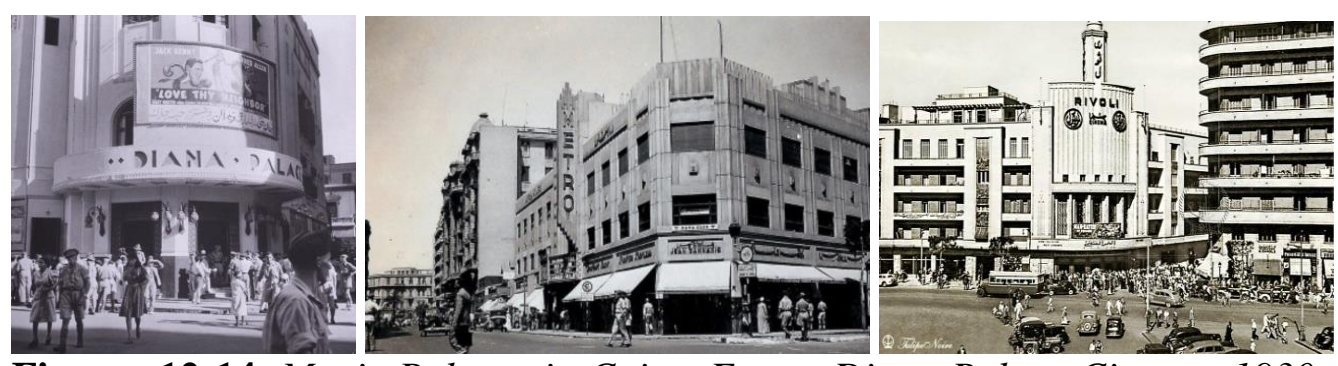

Figures 12-14. Movie Palaces in Cairo, Egypt: Diana Palace Cinema, 1930s, MGM Cinema, 1940, Rivoli Cinema, 1948

Source: https://thecairoscene.me/ArtsAndCulture/12-Movie-Theatres-From-Egypt-s-Golden-Age.

In Istanbul films were first screened in multifunctional buildings: ${ }^{20}$ theatres used for plays or music halls or other kind of performances (like Süreyya Opera House in Kadıköy) (Figure 16). The entrance part usually led to the street bazaars. Those buildings are mainly privately owned by public cooperation. Currently some of these became part of a shopping mall or have been completely demolished like the historical Emek Movie Theatre in Taksim (1884-2013) (Figure 15). In Turkey open-air cinemas were also common to find, according to regional climate conditions. Especially in Izmir during the ' 60 's open-air cinemas was highly preferred. A number of drive-in cinemas were also available. The open-air cinema spaces were hosted in large gardens and spectators used to sit on simple wooden chairs. This kind of places represented a special entertainment at the summer nights in almost every neighbourhood of the city.

19. 12 Movie Theatres from Egypt's Golden Age, Cairoscene. [Accessed 28 June 2019.] Retrieved from: https://thecairoscene.me/ArtsAndCulture/12-Movie-Theatres-From-Egypt-sGolden-Age.

20. Turkish Cinema, Turkish Culture Foundation. [Accessed 28 June 2019.] Retrieved from: http://www.turkishculture.org/performing-arts/film/turkish-cinema-591.htm. 

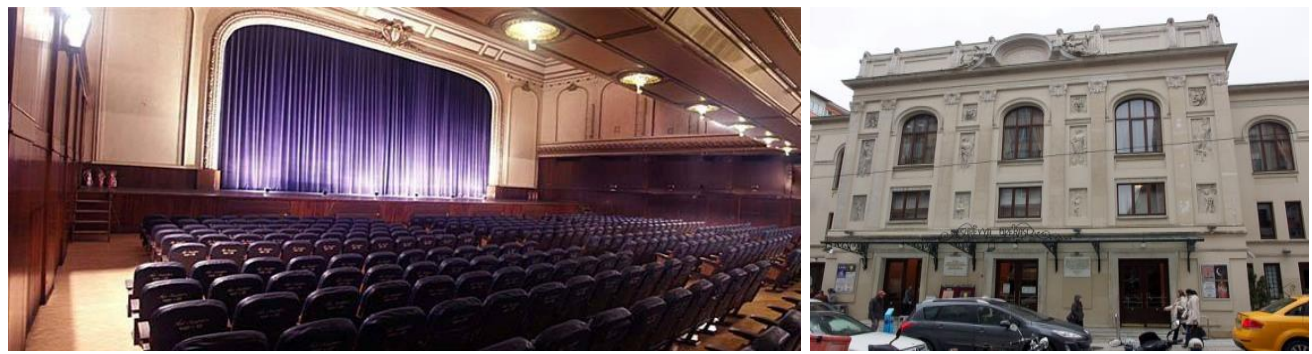

Figures 15-16. Movie Palaces in Istanbul, Turkey: Emek Movie Theatre, 1884; Süreyya Opera House, 1927

Source:https://images.app.goo.gl/kDX23LcbusHQSdXd9; https://en.wikipedia.org/wiki/S\%C3\%BCreyya_Opera_House.

In the case of Athens, it is important to highlight Rex Cinema (Figures 1718). The building still exists but is functionally closed. It has a monumental façade imposing its presence in one of the busiest streets of the city centre near Omonia Square. It was designed by Kassandras and Bonis as a multi-purpose entertainment venue and it features significant Art Deco elements. In addition, outdoor screening was arranged on cinema building roof tops, like in the case of Cine Paris in Plaka.

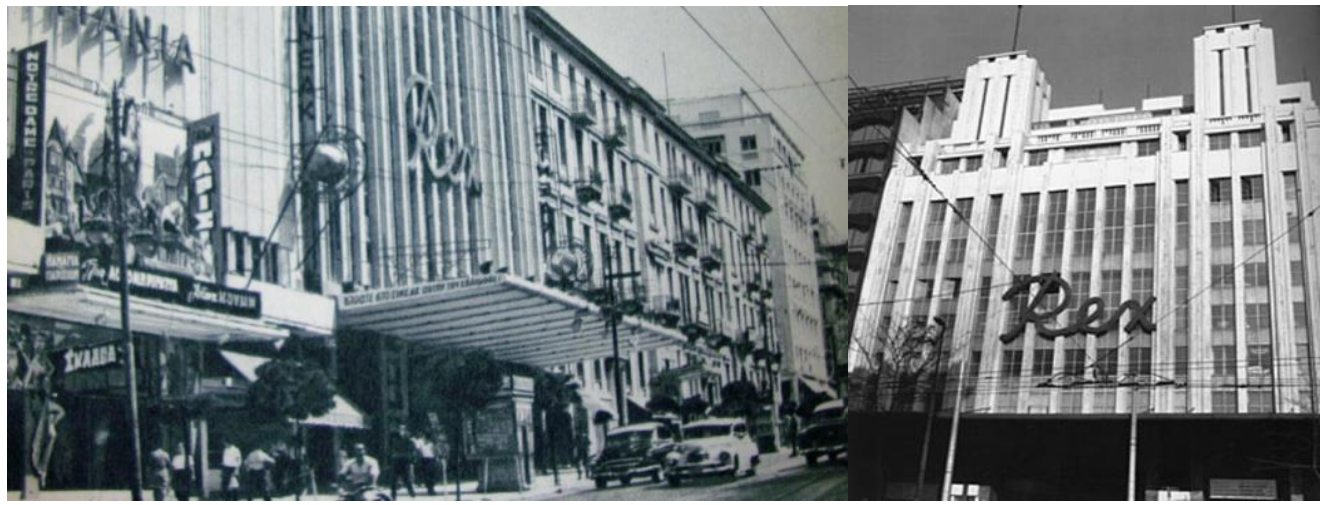

Figures 17-18. Rex Cinema in Athens, Greece, 1935-1937

Source: http://www.ekathimerini.com/219106/article/ekathimerini/life/rex-the-venue-thatbrought-a-slice-of-the-big-apple-to-athens; https://www.athenssocialatlas.gr/en/article/cinemas/.

In other areas of Mediterranean basin, in Rome, Italy, the development of the typology was similar. In the beginning, big theatres like Adriano, Ambra Jovinelli, and Italia Cinema (Figure 19) were used to host music performances and movie screening besides plays. After the 1930s, a new target was given to the design and construction of cinema places all around the country as well as the newly annexed colonies like Eritrea, Ethiopy and Somaly. By this time, cinemas became a popular form of entertainment, but they were also used for political propaganda. Buildings like Aquila (Figure 20), Impero and Induno Cinemas should also be mentioned.

During the 1950s and the 1960s the Italian cinema industry had a serious increase in demand for more movies and, as a consequence, for more venues to watch them. More elaborate and brave structures started to appear as new cinema halls designed by renowned designers such as Adalberto Libera and Riccardo Morandi. In Rome, often, no specific buildings were built as cinema halls but 
basements and ground floors of residential blocks were refurbished or designed for such function. ${ }^{21}$

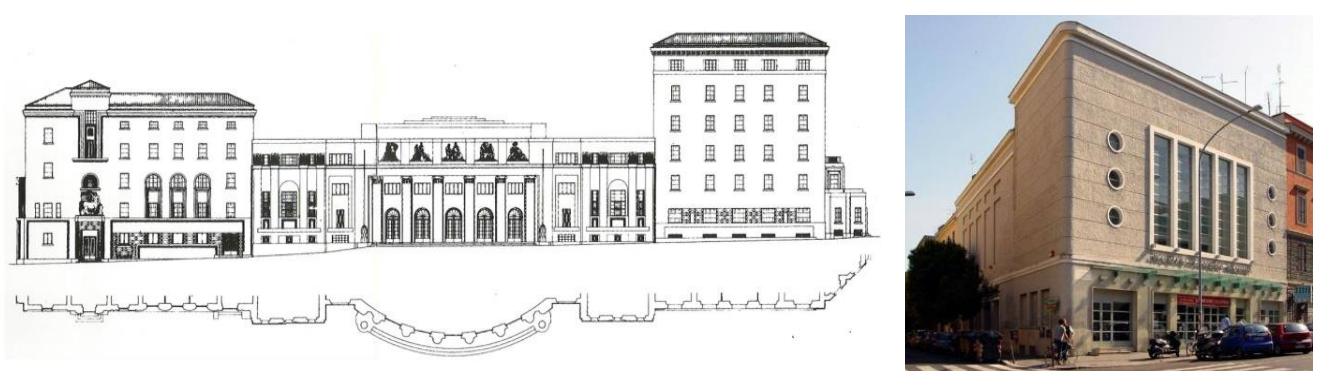

Figures 19-20. Cinema Theatres in Rome, Italy: Italia Theatre, 1929; Aquila Cinema, 1930s

Source: http://www.archidiap.com/opera/dopolavoro-ferroviario/; https://www.artwave.it/cinema-eserie-tv/notizie-e-rassegne/i-cinema-di-roma-fra-chiusure-e-riaperture-il-caso-del-maestoso-e-delnuovo-aquila/.

\section{Cinema Buildings and Open Air Cinema Spaces in Cyprus: Architectural and Spatial Qualities}

There were around thirty one cinemas in the main cities of the island. There were 6 in Limassol, 3 in Larnaka, 3 in Famagusta, 2 in Pafos, 2 in Kyrenia and at least 15 in Nicosia. In addition to the cinemas in the urban areas, there was also one open air cinema at least in every large village. However, both open air cinemas (summer cinemas) and closed cinemas (winter cinemas) were with better facilities in cities, therefore people used to travel from villages into cities to watch movies.

Some of the features explained in the earlier section can be revised in Cyprus as well. In general all around the Island different situations and qualities for the cinema halls can be found. Eclectism, Colonial influences, reflections of modern movement language and some examples inspired by Art Decò (echoing the splendours of American movie palaces) were found. Looking into a closer perspective to the buildings, often the main volume was formed of a simple box with rational envelope. The greatest emphasis was spent for the main facade and entrance, often placed in the corner and monumentalized by the use of steps, arches, columns, canopies and light bulbs signs.

Usually the structures were reinforced concrete, simply plastered or finished with marble or local sandstone in the more valuable parts, which were the main entrance and foyer. The first and architecturally more valuable cinema buildings in Cyprus seem to be those built in Limassol. Rialto Cinema (Figures 21-22) was built in 1930-32 on a project by Benjamin Gunzburg then renovated in 1949 by Charilaos Dikaios. Its rational, symmetrical façade shows some steps from the street leading to a portico with four columns, two large windows are at the side of it. Above the portico level, a three part elevation is defined by windows, the biggest in the middle just below the big sign with the name of the cinema. The solid part of the elevation is treated with a motif of lozenge. Influences of the

21. M. R. Intrieri, Le Sale Cinematografiche tra Ricordo e Attualità (Rome: Prospettive Edizioni, 2004), 3-21. 
elegance of Nordic classicism can be revised in this building. It has been refurbished recently and it is still in use and hosts film festivals every year. ${ }^{22}$
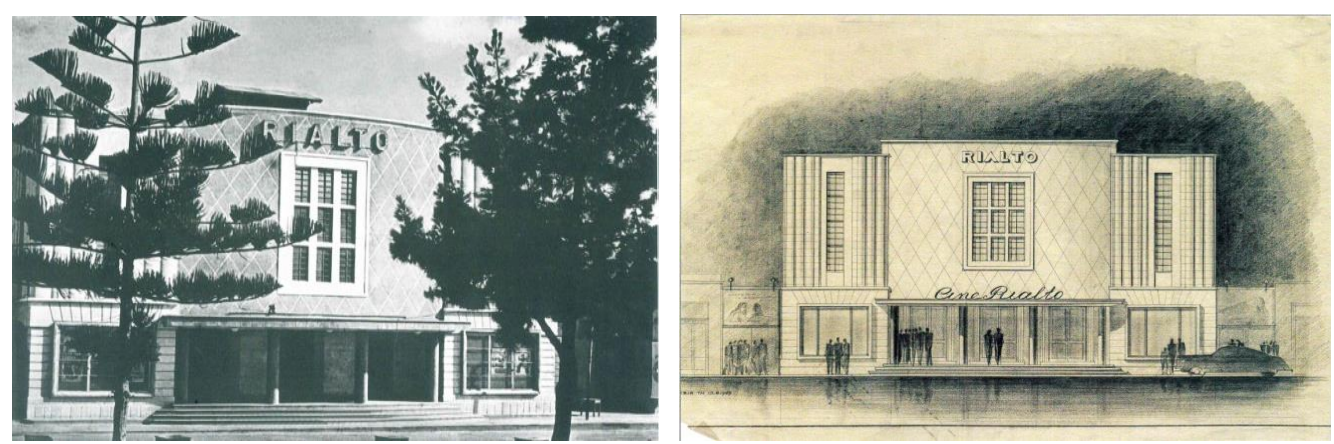

Figures 21-22. Cinema Theatres in Cyprus: Rialto Cinema, 1930-1932

Source: Georghiou, The Architecture of the Cypriots during British Rule 1878-1960, 2018, 186-187.

In the same city, Pallas Cinema (Figures 23-24) is another significant building built in 1948-1949 and designed by the Technical Office of Rousou and Pericleous and the Technical Organization of Panayiotis Stavrinides. Its outstanding façade shows Art Decò features, with, again, a symmetrical distribution. The convex main body of the building contains in the centre a concave shorter part, to which a concrete canopy is attached in order to provide shadow to the entrance. A taller tower shaped part cuts in the middle the convex main body of the building. Rows of windows underline the curved or vertical lines of the composition. The building is finished with marble cladding. ${ }^{23}$
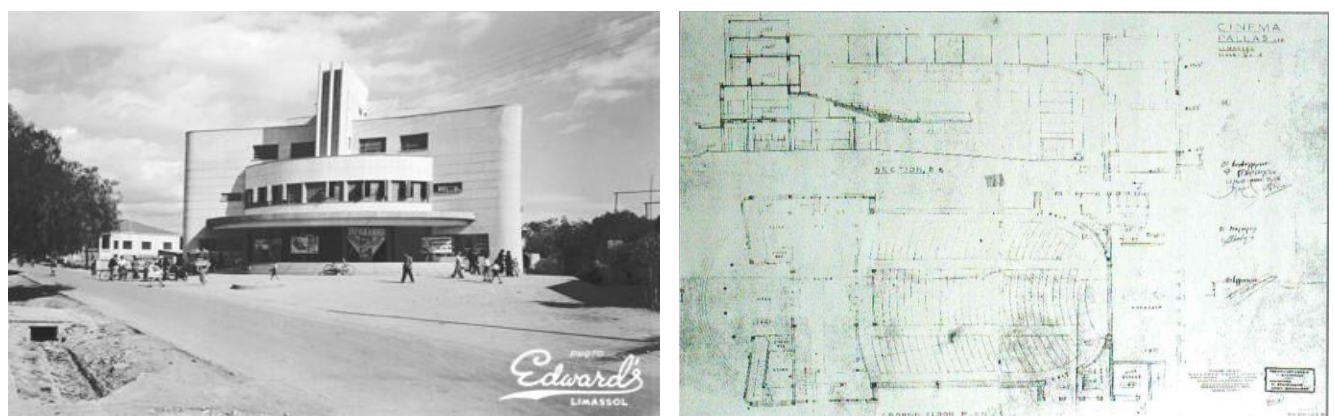

Figures 23-24. Cinema Theatres in Cyprus: Pallas Cinema, Limassol 1948-49 Source: https://www.facebook.com/groups/frozencyprus/photos/.; Georghiou, The Architecture of the Cypriots during British Rule 1878-1960, 2018, 362.

Yordamli Cinema was also a well known and popular cinema among the community, with large space and elaborate architectural qualities with emphasised entrances with steps and symmetrical front façade.

In Famagusta, a number of cinemas could be found in the Walled city and Maraş/Varosha area. The Ireon Cinema (Figure 25) was built around 1950s probably by Odysseas Tsangarides. ${ }^{24}$.

22. Georghiou, The Architecture of the Cypriots during British Rule 1878-1960, 2018, 186.

23. Ibid, 362

24. Ibid, 365 . 


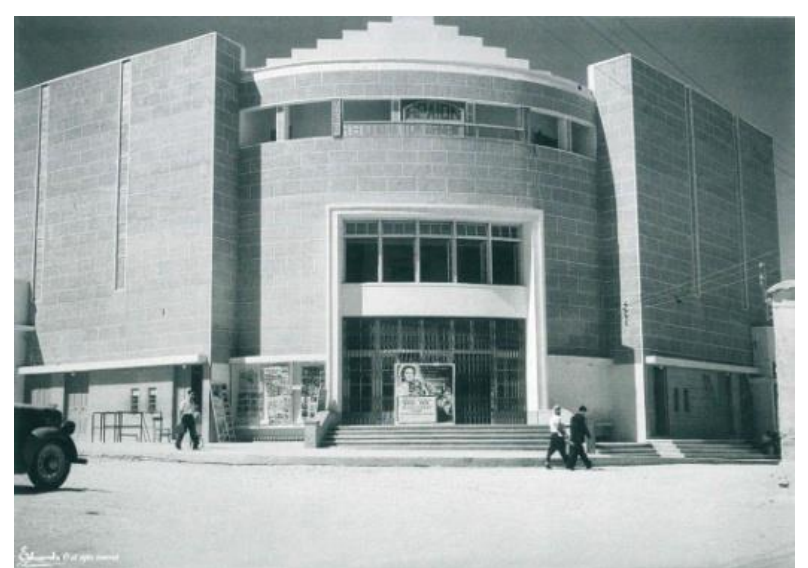

Figure 25. Cinema Theatres in Cyprus: Ireon Cinema, Famagusta, 1950s Source: Georghiou, The Architecture of the Cypriots during British Rule 1878-1960, 2018, 365.

Again a symmetrical façade is visible starting from a corner. A large entrance is placed above few steps and emphasised by big windows on top. Simple bulky wings, finished with local stone, embrace the rounded entrance corner, treated with the same material. On top, a stepped pediment reminds of a ziggurat or other Middle East charming structures.

In the same city, Hadjichanci (Figure 26) and Yildiz (Figure 27) Cinemas should also be mentioned. The first one is a small and modest building with a triple entrance in the centre of the elevation with tickets offices on both sides and a taller ceiling on top. Yildiz cinema, which may be a refurbishment of an older building, shows more eclectic/vernacular motifs. A curved corner opens in three pointed arches. On top of them, a sort of jumba, with several smaller glazed pointed arches, carries the sign with the name of the cinema.
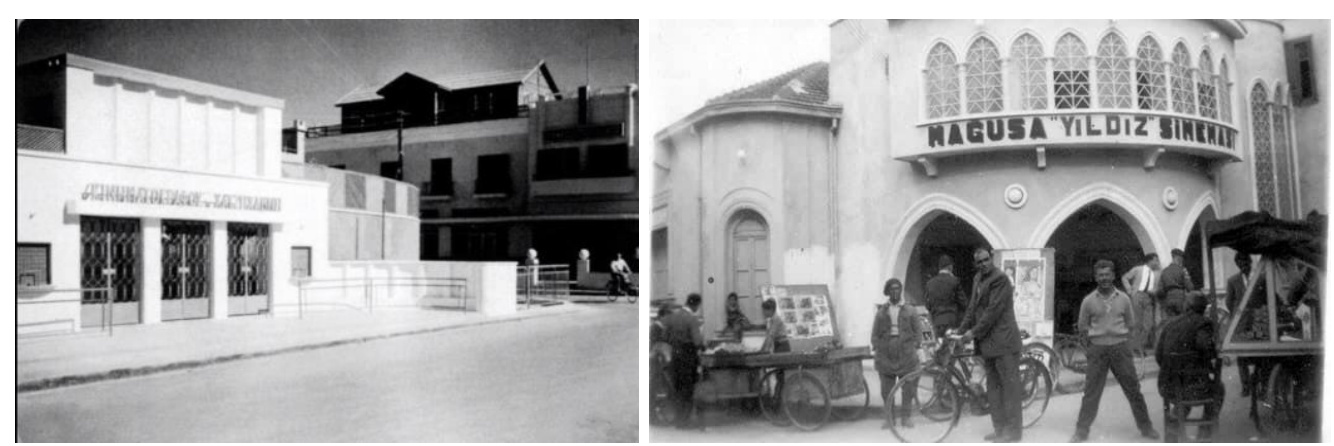

Figures 26-27. Cinema Theatres in Cyprus: also Hadjichanci and Yildiz Cinema, Famagusta

Source:https://en.wikipedia.org/wiki/Famagusta\#/media/File:CinemaXXampi.jpg; https://www.facebook.com/groups/frozencyprus/photos/.

Another architecturally interesting case is the Ellas Cinema (Figures 28-29), built around 1950 in Limassol and designed by Charilaos Dikaios. The regular façade is curved by a void hold by two big columns. The lower part is defined as a long portico covered with a concrete canopy carrying the sign of the cinema. The upper part is closed by a big glass surface with, at the sides, a frame of rounded 
corners. Above the void there are some squared regular openings while, on the sides, circular, port holes-like windows. The general composition reminds about typical modernist grammar. As Rialto Cinema, it echoes Nordic classicism but with more severe monumentality. This building has unfortunately been demolished. ${ }^{25}$
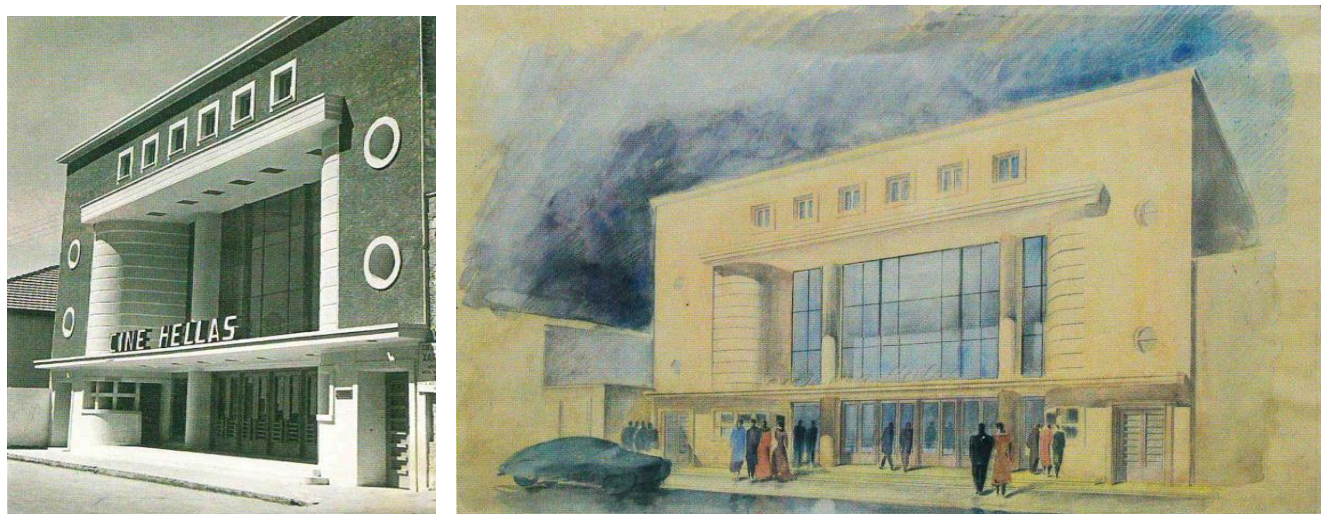

Figures 28-29. Cinema Theatres in Cyprus: Ellas Cinema, Limassol, 1950

Source: Georghiou, The Architecture of the Cypriots during British Rule 1878-1960, 2018, 366.

There were cinemas also in Kyrenia (Figure 30) but unfortunately they do not exist anymore. One was Catsellis Cinema, close to Dome Hotel near the historic harbour and another was St. Hilarion Cinema in Cengizhanli street, at the back of the historic city centre.

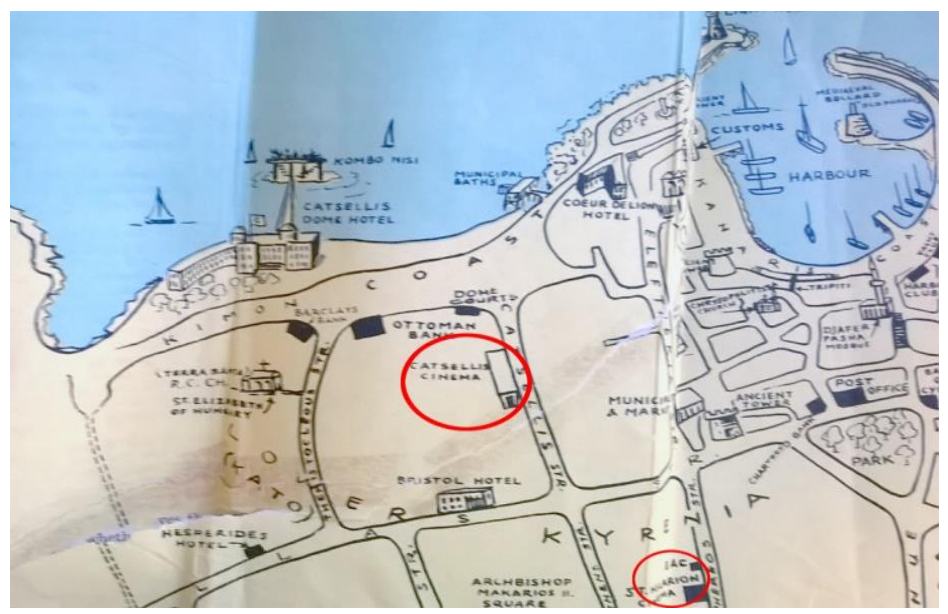

Figure 30. Map of Kyrenia Showing the Location of Catsellis Cinema and St. Hilarion Cinema

Source: Image composed starting from pictorial map of Kyrenia town drawn by J. Sabry, 1955, in Keshishian K. K., Romantic Cyprus guide book.

In the capital city of Nicosia, first the Papadopoulos Theatre (Figure 31) was used for motion picture screening while one of the first building built for the specific purpose was the Pallas Cinema (Figure 32), designed by Panayiotis Stavrinides in $1948-1949 .^{26}$

25. Ibid, 366

26. Ibid, 363-364. 


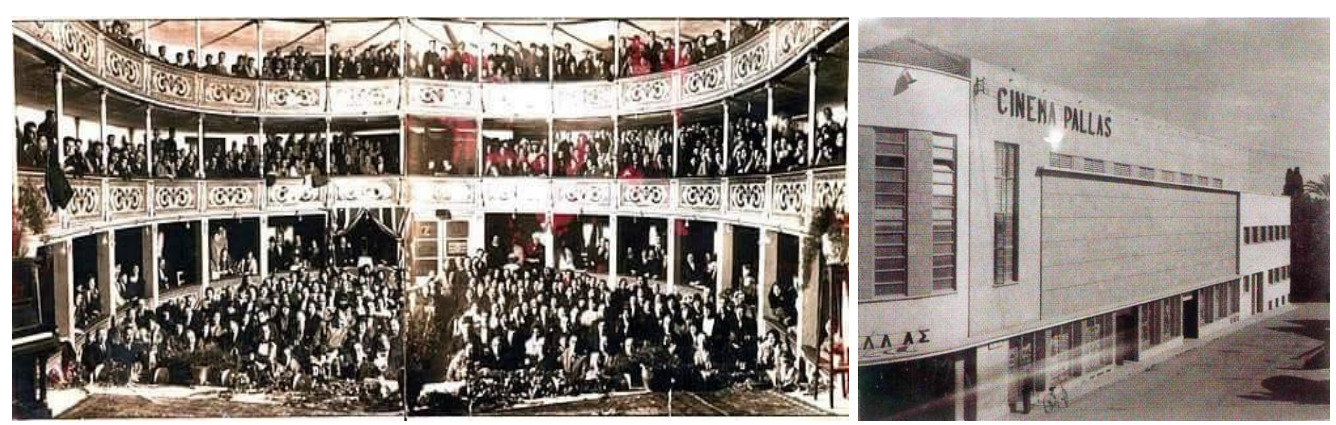

Figures 31-32. Cinema Theatres in Cyprus: Papadopoulos Theatre and Pallas Cinema, Nicosia

Source: https://www.facebook.com/groups/frozencyprus/photos/; Georghiou, The Architecture of the Cypriots during British Rule 1878-1960, 2018, 363.

The abovementioned shows clear references to a severe modernism. The entrance is placed in the corner and made evident through a dark rounded portico crowned by vertical openings in "iron-window" profile. The sides of the buildings are quite simple and the main composition is brought together by the change of materials, local stone, white plaster, glazed surfaces. As Rialto Cinema, Pallas Cinema has also been recently renovated and it works as cultural centre. Other well-known Greek cinemas were Lukudi and Magic Palace Cinemas.

\section{Development of Cinema Sector and Emergence of Cinema Buildings and Spaces in Cyprus with a Focus on the Turkish Cypriot Community: Nicosia as a Case Study}

In 1913, black and white, silent, short movies started to be shown to public at shabby halls surrounded by canvas curtains, at festivals, village fairs as well as coffee shops. During summer nights, open spaces were used. There was no electricity, thus projectors working by hand were used. In those years, the building structure and the space quality was not the priority, it was important enough that $20^{\text {th }}$ Century's new invention 'cinema' could meet the public in Cyprus. ${ }^{27}$ The first cinema hall (indoor or outdoor) in the Walled City of Nicosia is known to be close to Sarayönü square (Figure 33); however, there is no traces left behind this cinema hall.

27. Tolgay, Kibris 'in Orta Yeri Sinema, 2016. 


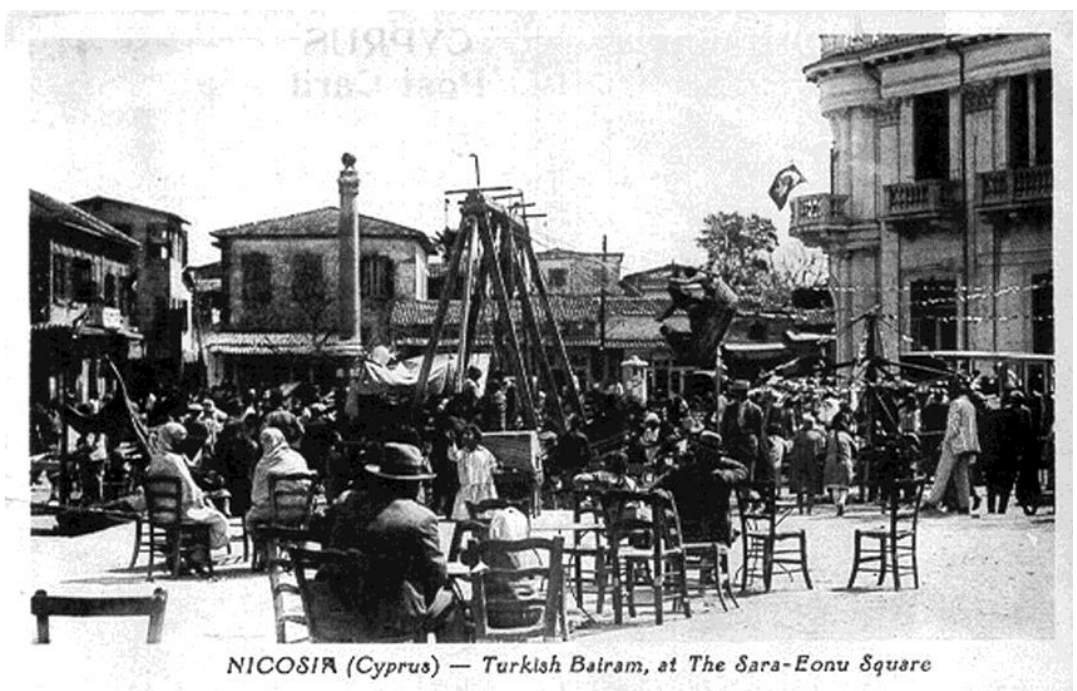

Figure 33. Sarayönü Square in 1925 (It was an important square for entertainment and first cinemas were also developed around this square) Source: A Historic Postcard, Kyrenia National Archieve.

Beliğ Paşa Cinema is known to be the first cinema building and most elaborate Turkish cinema. ${ }^{28}$ The owner Beliğ Paşa was a well educated lawyer, who studied in Sarbonne University with a scholarship. After practicing law in Cairo, he decided to return back to Cyprus and opened a cinema hall in the mid 1930's for contributing in the cultural development of his country. The plans of the cinema hall was imported from an Egyptian cinema hall in Cairo. ${ }^{29}$ This is a good example for how Modern Heritage in Cyprus was influenced from Eastern Mediterranean countries. In 1954 the cinema hall was burned down due to an unknown reason and unfortunately there are no pictures or drawings of the cinema building.

Since 1933, the Turkish community started bringing Yeşilçam films from Istanbul. Papadopoulos cinema in the southern part of Walled City of Nicosia, which belonged to a Greek Cypriot was rented to show these movies. However, the box office did not show enough success. Until 1945, the Turkish cinema sector went through a stagnation period. On the other hand, until 1950s Greek cinemas were in high demand with foreign films. A Turkish Cypriot investor started to import films from Istanbul on a regular basis. In 1947 the film industry started to rise and businessmen started investing in this sector. The first film company was established in this year. ${ }^{30}$ In 1949 , there was again a stagnation period in the cinema industry due to increase in rent prices of the cinema halls because of growing interest. In 1950, Halk Sinema Limited constructed a new open-air cinema space in Çağlayan and nameed it as Halk Cinema. ${ }^{31}$ According to Tolgay, the locals were keen to use this cinema and not miss any movie screenings, thus the cinema sector started rising again.

28. Tolgay, "Beliğ Paşa ve Tarih Yazan Sinemasi," 2017.

29. Tolgay, Kibris'in Orta Yeri Sinema, 2016.

30. Ibid.

31. Ibid. 
Some other sectors emerged as a result of this growing cinema sector. In order to increase public interest, advertisement was crucial, however, this was very expensive. If the movies were not announced, the box office would be in a disadvantaged economic situation. Along with these problems, first publishing house was established. Çigirtkan (barker) which is called to the person who would announce the movies by shouting in the streets, was another source of advertising.

Kristal Cinema, which was one of the open-air cinemas, becomes frequently used in 1947 due to a number of popular movies. Turkish Cinema Limited which was established and was working through renting out different cinema halls to screen their movies. However, this was not economically stable and profitable business to continue. In 1950, Turkish Cinema Limited was closed down. Later, Cyprus Turkish Film Limited was established and they used the Atlas Cinema and Istanbul Cinema as their cinema halls to show their movies. Atlas Cinema then changed its name into Beyrut Cinema. ${ }^{32}$ The names of the cinemas were changing when the owners or business partners were changing.

According to an interview respondent who owns an open air cinema, open air cinemas was usually surrounded by steel panels, which were cheap and practical to find. The space was organised in a way that the screen was facing towards south in order not to be affected by the moonlight. For better vision, there were few platforms on ground and the screen was built over brick wall rendered with plaster. Usually, people would bring their own wooden chairs from their home. For kids, cinema space would provide them long wooden benches. The sound of the movies were spread through the neighbourhood, where some people were watching the movie from their balconies. Open air cinemas were almost an extension of the outdoor spaces of the houses in that neighbourhood. It was an important link between private space and public open space.

Turkish Cinemas in the Walled City of Nicosia and its Close Surrounding: their Transformation

Turkish cinemas in the northern part of Nicosia (Figure 34) were located in three main locations (Table 1). First area is within the Walled City of Nicosia, second and third areas are just outside the Walls which are called Çağlayan and Köşklüçiftlik neighbourhoods.

32. Ibid. 


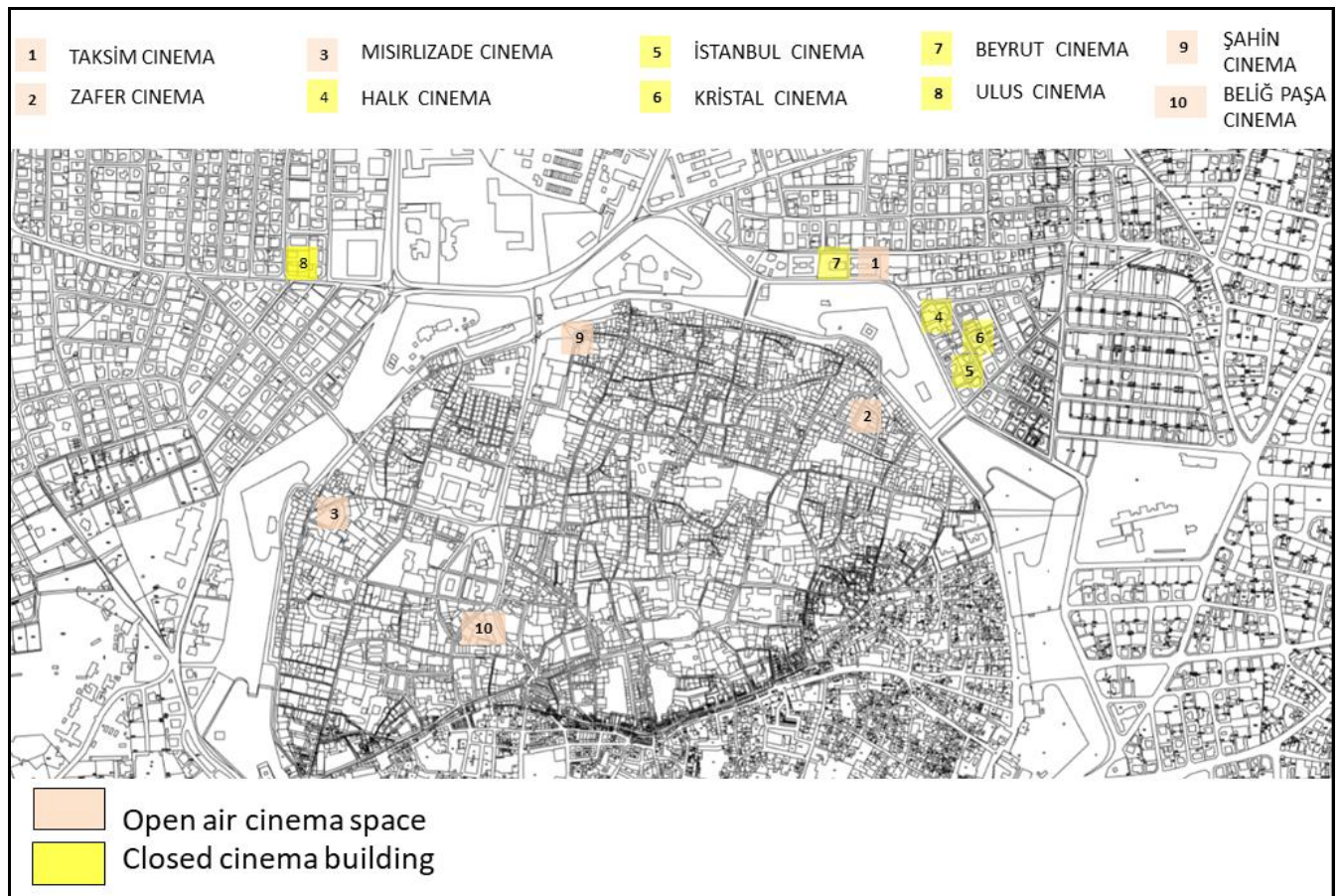

Figure 34. Turkish Cinemas Located in the Northern Part of Nicosia, Built and Used between 1938-1980s

Source: Menteş and Donà, 2019.

Table 1. Open Air Cinema Spaces and Closed Cinema Buildings Located in Three Main Locations, Çağlayan Neighbourhood, within the Walled City of Nicosia and Köşklüçiftlik Neighbourhood

\begin{tabular}{|c|c|c|c|c|c|}
\hline \multicolumn{2}{|c|}{$\begin{array}{c}\text { Çağlayan neighbourhood } \\
\text { (outside the Walled City } \\
\text { of Nicosia) }\end{array}$} & \multicolumn{2}{|c|}{ Walled City of Nicosia } & \multicolumn{2}{|c|}{$\begin{array}{c}\text { Köşklüçiftlik } \\
\text { neighbourhood } \\
\text { (outside the Walled City } \\
\text { of Nicosia) }\end{array}$} \\
\hline \multirow{4}{*}{ 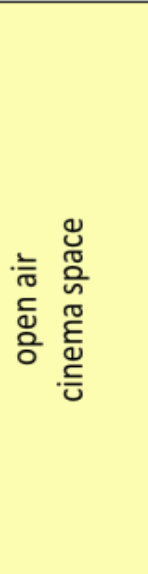 } & $\begin{array}{l}\text { KRISTAL } \\
\text { CINEMA }\end{array}$ & \multirow{5}{*}{ 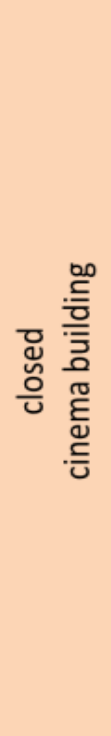 } & $\begin{array}{l}\text { BELIĞ PAŞA } \\
\text { CINEMA }\end{array}$ & 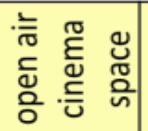 & ULUS CINEMA \\
\hline & $\begin{array}{l}\text { iSTANBUL } \\
\text { (ÇIÇEK or } \\
\text { ŞAHIN) } \\
\text { CINEMA }\end{array}$ & & $\begin{array}{l}\text { ZAFER } \\
\text { CINEMA }\end{array}$ & & \\
\hline & HALK CINEMA & & $\begin{array}{l}\text { ŞAHIN } \\
\text { CINEMA }\end{array}$ & & \\
\hline & $\begin{array}{l}\text { BEYRUT } \\
\text { CINEMA }\end{array}$ & & $\begin{array}{l}\text { MISIRLIZADE } \\
\text { CINEMA }\end{array}$ & & \\
\hline 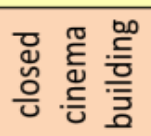 & $\begin{array}{l}\text { TAKSIM } \\
\text { CINEMA }\end{array}$ & & & & \\
\hline
\end{tabular}

Source: Menteş and Donà, 2019. 
Between 1938 and 1980, the most popular open air cinema spaces include Kristal Cinema, Istanbul Cinema, Halk Cinema and Beyrut Cinema in Çağlayan neighbourhood (Figure 34, Table 1). Taksim Cinema was the only closed cinema building in this neighbourhood and it also had an open air cinema space. In Köşklüçiftlik neighbourhood, there was also another open air cinema called Ulus Cinema within a large garden of a wealthy family. This cinema was opened in 1965 and closed down in 1973.

Due to dense urban context, open air cinemas were usually located outside the Walled City of Nicosia, whereas the closed cinema buildings were within the walls. There were four important cinema buildings; Beliğ Paşa Cinema, Zafer Cinema, Şahin Cinema and Misırlızade Cinema. By 1980s all cinemas were closed down. ${ }^{33}$ For many years these buildings and open spaces stayed as they were. However, due to changing life conditions, open spaces were filled with new apartments or petrol stations, whereas some of the cinema buildings were used as storage spaces or were demolished.

Until 2016, there were three cinema buildings, where the original architectural features and the structural integrity was still present. These buildings are, Taksim Cinema, Zafer Cinema and Misırlizade Cinema. However, Taksim Cinema was demolished due to private owner's own will and due to no preventions against destruction of modern heritage.
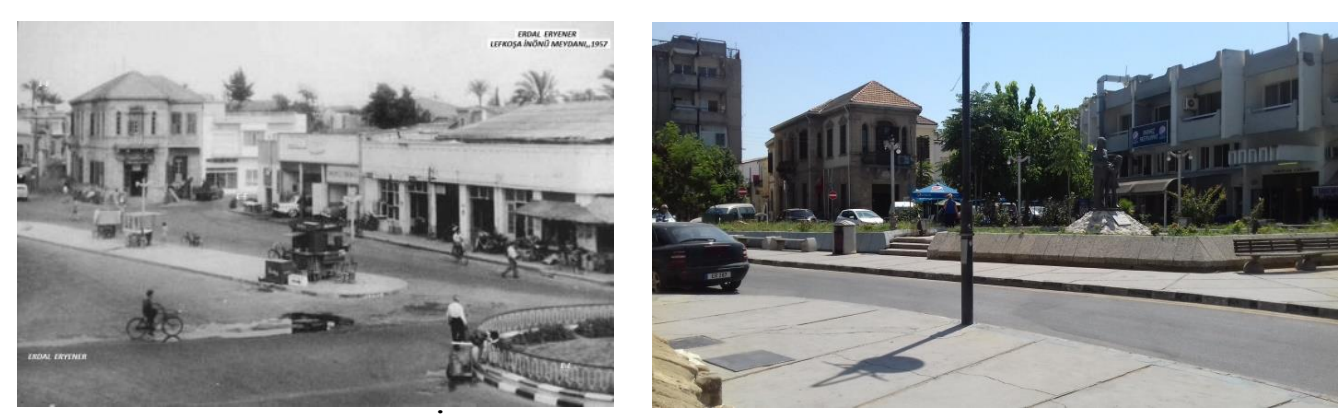

Figures 35-36. Nicosia İnönü Square 1957 (left), and 2019 (right) shows Old Ford Garage Space and the Complex of Vakiflar Pasaji

Source: Erdal Eryener, 1957, Menteş and Donà, 2019.

In addition to these, Şahin cinema building was located behind the old Ford garage space (Figure 35). This long building was then demolished and a similar new one was built (Figure 36). Within the new complex, another cinema was opened under the name of Vakif Cinema. Today, the name of the whole complex is Vakiflar Pasaji and the Vakif Cinema hall's traces remain inside (Figures 3740).

33. Bağişkan, T. "Çağlayan Mahallesinin Uzak ve Yakin Geçmişi 3,” Yenidüzen Gazetesi, 2016. 

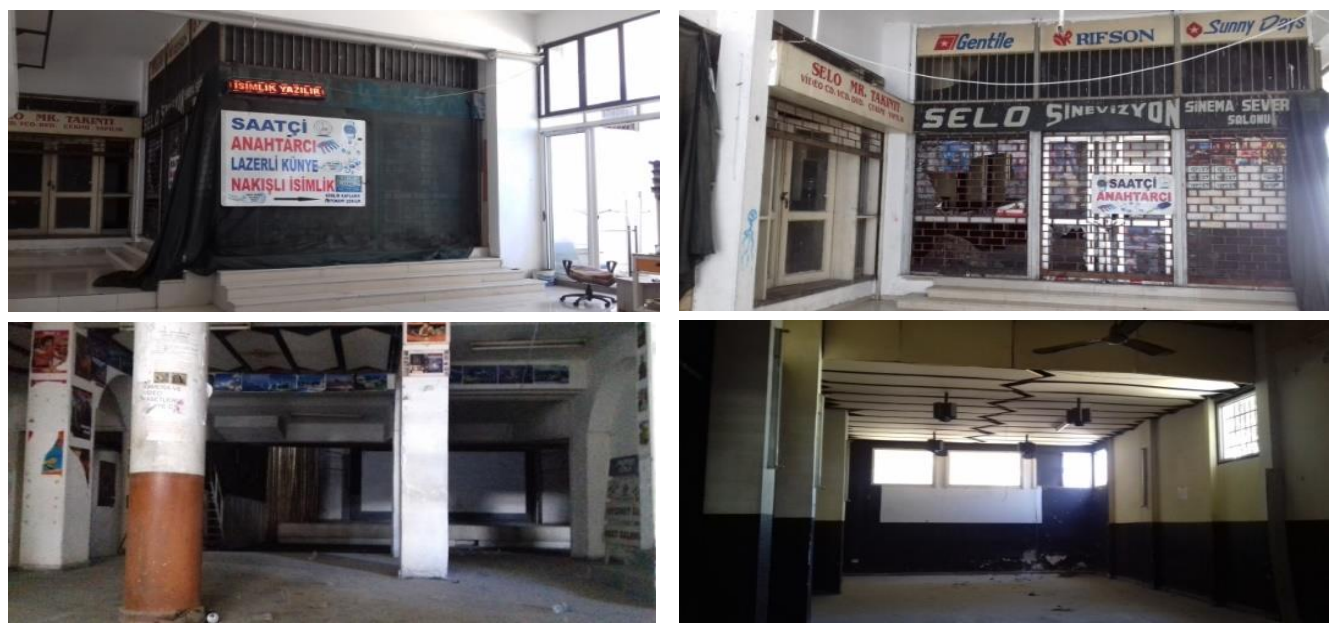

Figures 37-40. The Interior of the Old Vakif Cinema within the Complex of Vakiflar Pasaji within the Walled City of Nicosia

Source: Menteş and Donà, 2019.

\section{Taksim Cinema}

Taksim Cinema was built in the late 1950s and located at Şehit Albay Karaoğlanoğlu Caddesi in Çağlayan neighbourhood. The front façade of the building was parallel to the main road, across the Çağlayan park, where the fun fairs would take place. This cinema also had an open air hall and it was one of the largest cinemas. Therefore in the 1960s it was used for different purposes. Concert hall, performance hall, stand up shows, poetry nights, weddings, end of year school concerts were some of these purposes.

Between 1980s and 2016, Taksim Cinema stayed vacant and in bad condition (Figure 41). During time, homeless people occupied inside to sleep and use drugs. ${ }^{34}$ These negative situations also appeared in the media. No protection regulations towards modern heritage in the northern part of Cyprus enhanced the threaths of the building. The privately owned property was also not conserved by its owner and in 2016, the cinema was demolished ${ }^{35}$ (Figure 42). Since 2016, the plot of the building stays empty.
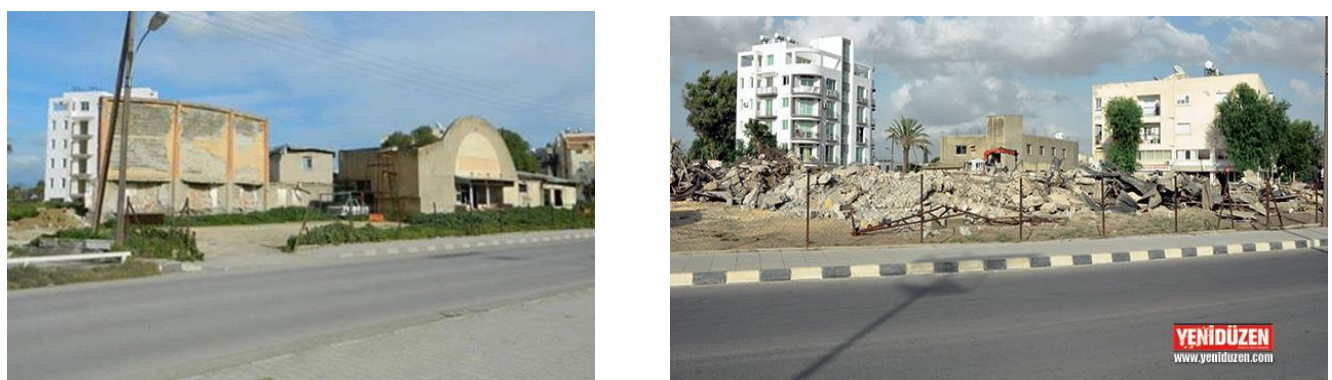

Figures 41-42. Taksim Cinema in 2016 Before and After it was Demolished Source: Yenidüzen Gazetesi, 2016; Haber Klbrls, 2016.

34. Yenidüzen Gazetesi, "Tarihi Taksim Sineması Yıkıldı,” 2016.

35. Haber Kıbrıs, "Buldozerler Lefkoşa'daki Tarihi Sinemaları Yıktılar,” 2016. 


\section{Zafer Cinema}

Zafer Cinema was built in the 1950s within the Walled city of Nicosia at Plevne street, on the way to go out of the walls towards Çağlayan neighbourhood. Located in a dense urban context, the building is attached to other buildings (Figure 43). A symmetrical façade is visible starting from the corner. A large entrance raised above with steps and curving along the corner is emphasised with columns left outside and large windows on top. Some letters of the cinema's name, written on top with iron frames, are still visible today (Figure 44). The capacity of the cinema hall is known to be around $1200 .^{36}$

Currently the building stays abandoned, partly as a storage and most of it is vacant. The owner of the building states that 'the storage includes almost 200 Turkish movies with their posters. ${ }^{37}$ These are important historical archive, however, their value is not yet appreciated and/or supported.

The current neighbourhood profile is low income group with a dominating residential area. It is still a landmark building in the neighbourhood and it can be re-used as a cinema or as a culture-related function to enhance the use of public spaces and bring back the community's memories in the area.
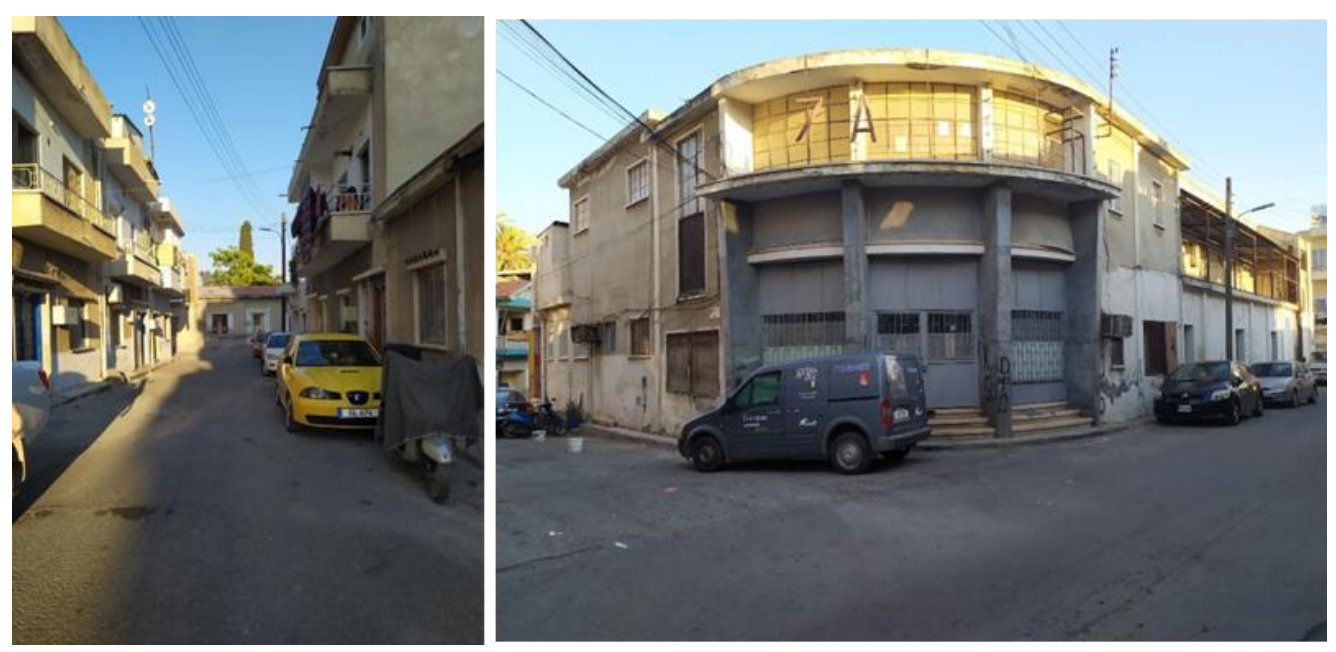

Figures 43-44. Zafer Cinema at Plevne Street, the Front Facade of the Cinema Source: Menteş and Donà, 2019.

\section{Misırlızade Cinema}

Misirlizade Cinema is located in Arabahmet neighbourhood within the Walled City of Nicosia at the junction of Nuri Efendi and Tanzimat streets. The cinema was built in the beginning of 1970s and was opened by the mid-1970s. Even though this paper aims to analyse cinemas until 1960s, this building is important to mention since it also carries significant features of late 1960s and it is one of the two cinema buildings that still exists. The cinema is a corner building

36. Tolgay, Kibris'in Orta Yeri Sinema, 2016.

37. Ibid, 62. 
within dense urban context (Figure 45). Entrance is emphasised with steps and a round column orients the entrance void stepped back from the street (Figure 46).

The cinema was closed down between the early 1980s and 1995. In 1995 the owner decides to regenerate the old cinema with its original function. After around 15 years of lack of cinema spaces in the northern part of Cyprus, the regeneration of this building was an important turning point for the future development of the cinema sector. Until the beginning of 2000's this cinema functions as the only cinema building and people arrive from different villages and cities to watch movies there.

In the beginning of 2000s new developments emerge as cinema buildings, as part of supermarket chains or shopping malls. Consequently the customers of Misirlizade Cinema drop increasingly. In 2017, the cinema was closed down due to lack of customers. Interior of the cinema still stands the same with its furniture since it was abandoned (Figures 47-48).

Currently, the building is in close proximity to administrative and business area. Courts, law firms, Chamber of Architects and a number of local shops can be found in this neighbourhood. Some entertainment alternatives include bars and cafes.
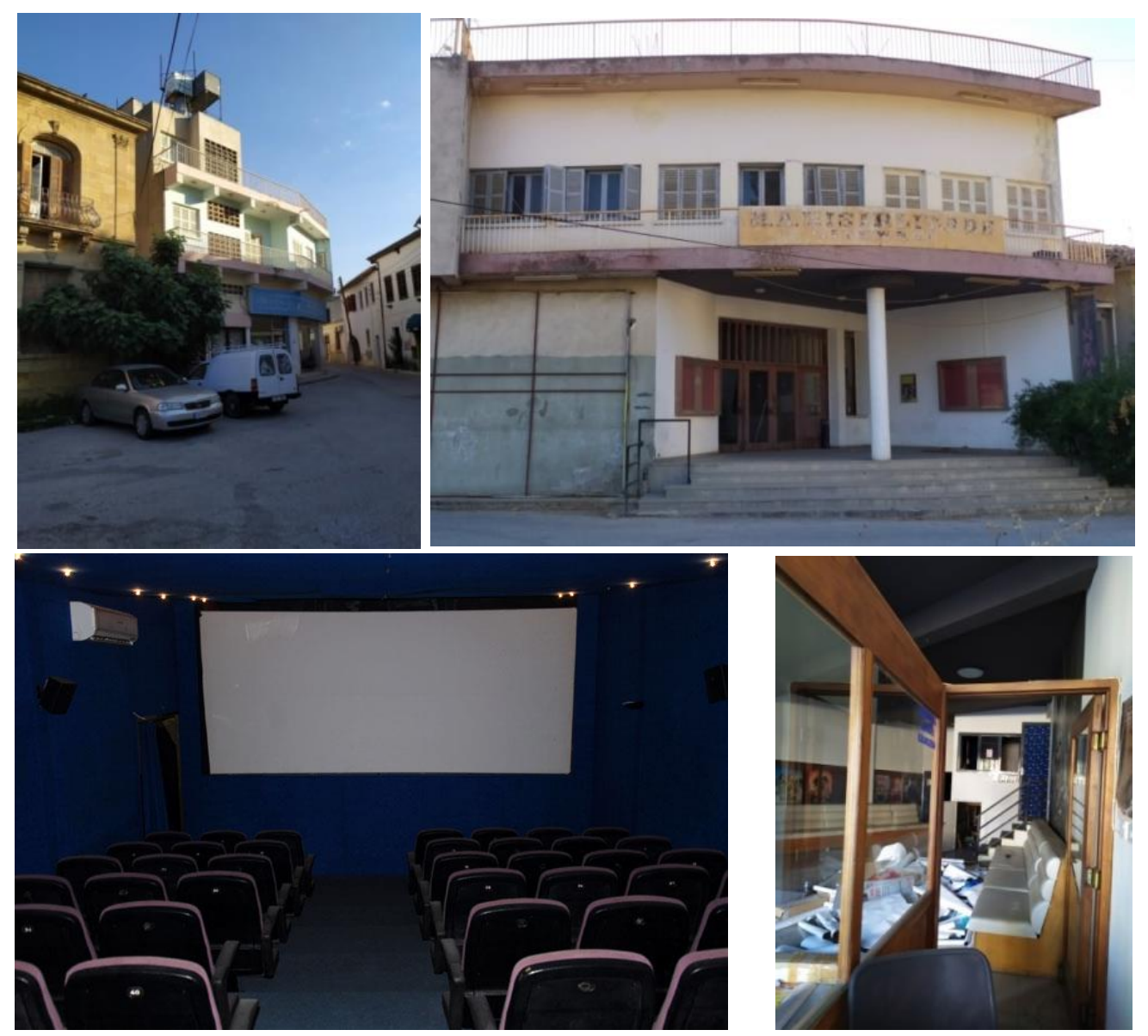

Figures 45-48. Misirlizade Cinema in Arabahmet Neighbourhood, the Front Façade of the Cinema and Interior Condition

Source: Menteş and Donà, 2019. 
Socio-Cultural Aspect, Cinemagoing Experience and Use of Public Spaces

Cinemagoing experience was an important entertainment and also one of the few options in such a complex time period where there was World Wars. Cinemagoing was the core socialising source either to spend time with family and friends as well as meeting new people.

Watching movies was giving the chance to have different topics to discuss with people other than the daily routines. Watching foreign movies, was one of the rare chances to catch up with Europe. Movies were usually reflecting new technologies, culture and customs of different places. In most Turkish movies, Istanbul was the main setting as it was the most popular city in Turkey and the city's development is visible from these movies.

Between 1920s and 1960s, Çağlayan neighbourhood was an important place to understand the process and significance of cinemagoing experience for Turkish Cypriot community (Figure 49).

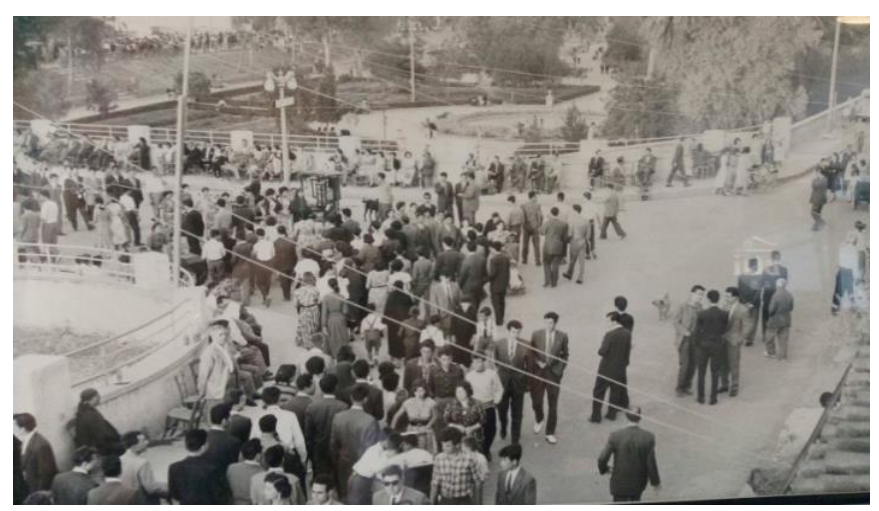

Figure 49. Square near the Çăglayan Park and Use of Public Open Space Source: 1920s and 1960s, Kyrenia National Archieve.

Between 1920s and 1960s, this neighbourhood was the heart of Nicosia entertainment, culture and social events. The neighbourhood had a number of different alternatives for entertainment and socialising, which were feeding each other for increasing the number of visitors to this area. The Çağlayan park, the fun fairs in and around the park, restaurants and patiserries, coffee shops, kebap shops, street sales were all part of cinemagoing experience (Figures 50-51).

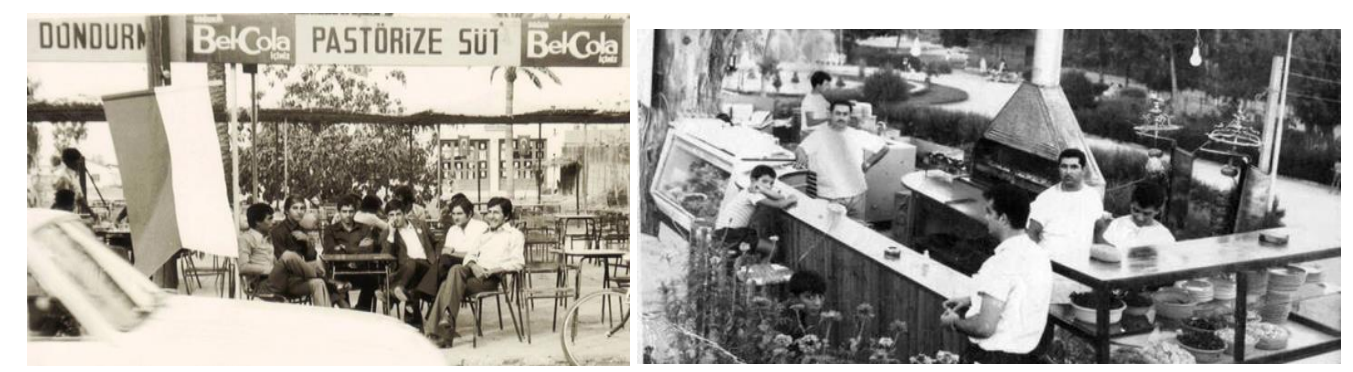

Figures 50-51. Well Known Local Kebap Shops at Çăglayan, where People Used to Visit Before or After the Cinema in the 1960s

Source: Kyrenia National Archieve. 
Street sales and cinemas were described as 'unseperable' by the questionnaire and interview respondents. Street sales included, pop corn, peanuts, cotton candy, bread (peksemet) and other local goods. One respondent describes her memories of the cinemagoing experience as "narrow streets smell of jasmine... they were selling jasmine on date leaves. For me summer nights were associated with open air cinemas and with jasmine smell" (woman, was born in 1947).

In the beginning of May, opening of the open air cinemas was accepted as the sign for the arrival of summer which was an important celebration. Yeşilçam movies are told to represent the cultural and social living conditions and drawing boundaries to the society. Most of the times, cinemas were meeting and socialising spaces for the young generation where the conservative living conditions would allow for innocent flirtation. ${ }^{38}$

"It was like a ritual to go to the cinema. It is not possible to express the excitement and happiness of cinemagoing... going to the cinema as a group, going out of the cinema all together. It was part of the cinema rituel to dress up nicely, stop by at the local restaurant, kebap shop, or at a patisserie before or after the cinema for long conversations." 39

Interview respondents quotes their memories about cinemas in Nicosia as:

"We used to go to the cinema with my family every Monday and Tuesdays. I was around 10 years old. At the entrance there was popcorn or peanuts... Once we entered, there was a man with a tray on his chest, selling refreshments. Single men were going to the cinema to see girls. I remember also going to the concerts in these cinemas. Also our end of school concerts and theatres would take place in one of the cinemas... We used to watch movies with different themes but mainly of war, love and passion. Some foreign movies I remember were The Rope, War and Peace and Niagara (Figures 52-54)" (woman, was born in 1950).

"I used to travel from the village to Nicosia to watch movies. The bus services would take us to the cinema and take us back. It was a very exciting journey for me. I was around 8 and I was saving from my pocket money to watch the movies... Inside of the cinema halls were a bit messy. Women would bring their babies, men were smoking, sometimes children were crying but everyone was happy to watch the movie" (man, was born in 1939).

Tolgay refers to Cinema Paradiso, which is a 1988 Sicilian movie and he resembles the cinema going experience in Cyprus with this movie, quoting that 'It was just like the festive feeling of this movie. ${ }^{40} \mathrm{He}$ also states that a cinema in Larnaka took its name after this movie 'Paradise Cinema'. Unfortunately in 2015 this building was knocked down as part of the Larnaka municipality's development plan and a car park space was created with the empty plot. Ironically, the same transformation happens in the film.

38. Ibid.

39. Ibid.

40. Ibid, 134. 

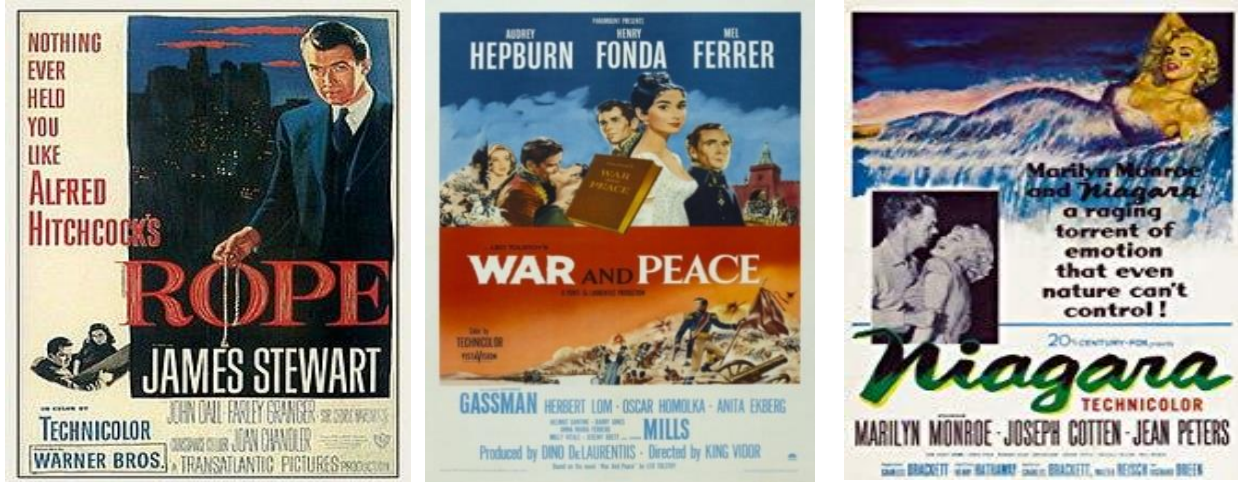

Figures 52-54. Some of the Posters of the Movies Mentioned by the Interview Respondents as Shown in these Cinemas in the Years of 1948, 1956, 1953

Source: The Rope by Alfred Hitchcock; War and Peace by King Vidor; Niagara by Henry Hathaway.

A resident of Nicosia and the owner of an open air cinema, called Hürriyet Cinema in Gönendere village (Figures 55-56), which was first opened in the 1950 's, is keen to continue their family business since 2014 . He is also a significant figure in emphasising the cinema culture in the northern part of Cyprus with sharing his archieve through three exhibitions between 2014-2017. In the last few years, there are some efforts also by the local authorities to protect intangible cultural heritage of Nicosia. Since 2017 August, 3 day festivals are organised by the local municipality in order to continue the nostalgic memory of Çağlayan neighbourhood, with open air cinema events and dance shows to attract visitors.

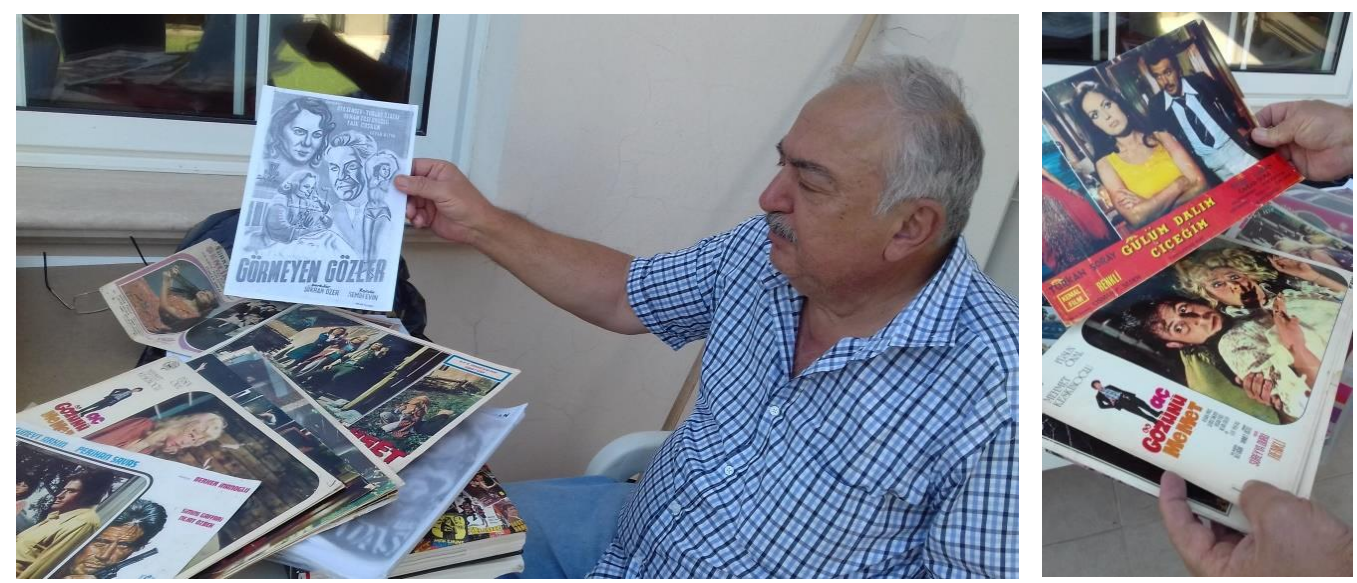

Figures 55-56. Yaşar Artam, an Interview Respondent's Archieve of Cinema Posters. More than 150 Turkish Movies from the Years of 1950s until 1980s Source: Menteş and Donà, 2019.

\section{Conclusions and Suggestions}

The findings of this research reveals two important results. One of them is linked to intangible aspect while the other is related to tangible aspect. The intangible aspect reveals that memory of cinemagoing experience is strong among 
the generation who used the open-air cinema spaces and cinema buildings between 1950 s and 1970s. Resembling these years with such a socio-cultural activity along with using these spaces, raises significance for their protection and/or for future regeneration. The cinemagoing experience could be considered as intangible heritage of Cyprus. The lack of inventory of these buildings is an important finding for the lack of interest by the authorities towards this building period, type and spaces. Cinema buildings are a part of the multifaceted urban landscape of Nicosia, a more recent contribution to the variety and richness of architectural languages and styles that is the main feature of the Walled City.

Among the Ottoman and British colonial legacy, few modernist buildings are valuable exceptions in the urban tissue. Those buildings bear witness to another complex stage of the history of the Island and its capital. Cinemas were landmarks of modern times, non-religious and non-political hubs of social life. Their urban role and their architectural qualities still show the importance they owned in the changing society. As in many other countries in the world, designers put their efforts in order to provide innovative projects for a new typology serving a new function. Cinema palaces had to be recognisable and attracting for the patrons, with appealing façades, astonishing interiors and welcoming and comfortable halls. A stream of influences flew through the Mediterranean Sea, spanning from Middle East to Spain, displayed in the porticoes, colonnades, pediments and fenestration composing the monumental entrances of the cinema halls. Thus reducing the distance between Cyprus and Continental countries. It is really important that the results of the efforts of those architects and engineers in Nicosia will not be erased, that one of the layer of the surprisingly wide architectural variety of the City will not depleted because of irresponsible narrow-mindness.

The Walled City of Nicosia (northern part) has been going through a regeneration period since the early 2000s, and many neighbourhoods are in need of rehabilitation both physically and culturally. New public uses are important to bring life and people back into the historic centre. The analysis of the questionnaire and interview repondents reveal that, local people are keen to continue the intangible heritage and urban memory of 'nostalgic cinema days' if there was an opportunity to regenerate open air cinemas as well as two existing cinema buildings that are closed. The encouragement of locals is hopeful for the future of the Walled City of Nicosia, saving the neighbourhood with the regeneration of historic cinema spaces and buildings. Therefore the last remaining historic cinema buildings, which are abandoned and in bad condition, should be re-evaluated for their re-use either to their original functions or another appropriate public usage linked to cultural purposes. Use of cinema buildings and spaces can be a positive regeneration tool. The cinemagoing experience could be considered as intangible heritage of Cyprus.

A holistic approach should be followed to enhance the significance of the remaining cinema buildings and spaces. Raising awareness towards local authorities and local investors is crucial. It is also important to emphasise the necessary protection regulations for the modern heritage in the northern part of Cyprus in order to prevent more destructions. A holistic approach should include 
cooperation of different local authorities and bodies as well as heritage and culture professionals to take precautions against destroying architectural modern heritage.

The ongoing research aims to continue for further research which will include recording and mapping the inventories of all historic cinemas in Nicosia and other cities of Cyprus. This will enable creating a valuable archieve to understand the broader picture as well as to prepare a basis for future protection for the remaining buildings.

\section{Acknowledgments}

Our thanks to all questionnaire and interview respondents and especially those who have generously shared their knowledge, contacts and memories: Tülin Ural, Yaşar Artam, Jale Oran, Şükran Menteş, Osman Saner, Behiye Müftüzade, Arif Feridun, Solmaz Feridun, Ahmet Tolgay, Ekrem Bodamyalizade, Aytan Suphi, Özkan Arkin for being generous with sharing information and memories about cinema buildings, spaces and cinemagoing experiences.

\section{Bibliography}

Bağişkan, T. Çağlayan Mahallesinin Uzak ve Yakin Geçmişi 3. [Far and Close History of Caglayan Neighbourhood.] Yenidüzen Gazetesi, 2016. Retrieved from: http:// www.yeniduzen.com/caglayan-mahallesinin-uzak-ve-yakin-gecmisi-1-84449h.htm.

Ercole, P., Gennari D. T., Dibeltulo S. and Vijver L. V. "Cinema Heritage in Europe: Preserving and Sharing Culture by Engaging with Film Exhibition and Audiences." Alphaville Journal of Film and Screen Media 11 (2016): 1-12.

Fereos, S. and Phokaides P. "Architecture in Cyprus between the 1930s and 1970s." Docomomo 35 (2006): 15-19.

Georghiou, C. The Architecture of the Cypriots during British Rule 1878-1960. Nicosia: En Tipis Publications, 2018.

Haber Kıbrıs. "Buldozerler Lefkoşa'daki Tarihi Sinemaları Yıktılar." [Bulldozers Destroy the Historic Cinemas in Nicosia.] 2016. Retrieved from: https://haberkibris.com/ buldozerler-lefkosadaki-tarihi-sinemalari-yiktilar-2016-09-21.html.

Hoşkara, Ş. Ö. and Doratlı N. "A Critical Evaluation of the Issue of Conservation of the Cultural Heritage in North Cyprus." ICANAS 38 proceedings (2007): 849-872.

Intrieri M. R. Le Sale Cinematografiche tra Ricordo e Attualità. [The Cinema Halls between Memory and Newness.] Rome: Prospettive Edizioni, 2004.

Kiessel, M. "Art Deco Architecture in Cyprus from the 1930s to the 1950s." Prostor - A Scholarly Journal of Architecture and Urban Planning 20, no. 1 (2012): 172-185.

Kiessel, M. and Tozan A. "The Passenger Steamer and Cypriot Modern." Prostor - A Scholarly Journal of Architecture and Urban Planning 19, no. 1 (2011): 218-222.

Lejeune, J. F. and Sabatino M. Modern Architecture and the Mediterranean. London-New York: Routledge, 2010.

Oze, E. et al. Cyprus 100 [Most] Important Buildings, Sites and Neighbourhood. Nicosia: Docomomo Cyprus, 2014.

Phokaides, P. "Virtual Tour - Architecture and Modernity in Cyprus," EAHN Newsletter [Newsletter of the European Architectural Historians Network] no. 2/09 (2009).

Pyla, P. and Phokaides P. "Virtual Tour - Architecture and Modernity in Cyprus." Eahn newsletter European Architectural History Network 2, no. 09 (2009): 36-49. 
Ron Van, O. and Haraguchi S. Identification and Documentation of Modern Heritage. Paris: UNESCO World Heritage Centre, 2003, 3.

Tolgay, A. Kibris'in Orta Yeri Sinema. [The Centre of Cyprus is Cinema.] Lefkoşa: Okman Printing Ltd., 2016.

. "Beliğ Paşa ve Tarih Yazan Sinemasi." [Belig Pasha and Historical Cinema.] Kıbrıs Gazetesi, 2017. Retrieved from: https://www.kibrisgazetesi.com/kultur-sanat/beligpasa-ve-tarih-yazan-sinemasi-h33092.html.

Yenidüzen Gazetesi. "Tarihi Taksim Sineması Ylkıldı." [Historic Taksim Cinema is demolished.] 2016. Retrieved from: http://www.yeniduzen.com/tarihi-taksimsinemasi-yikildi-69590h.htm.

\section{Websites}

12 Movie Theatres from Egypt's Golden Age. Cairoscene. [Accessed 28 June 2019.] Retrieved from: https://thecairoscene.me/ArtsAndCulture/12-Movie-Theatres-FromEgypt-s-Golden-Age.

Brunetta, G. P. "Sala Cinematografica." [Cinema hall.] In Enciclopedia del Cinema Treccani [Accessed 28 June 2019.] Retrieved from: http://www.treccani.it/enciclope dia/sala-cinematografica_\%28Enciclopedia-del-Cinema\%29/.

Movie Palace. Wikipedia. [Accessed 24 July 2019.] Retrieved from: https://en.Wikipedia. org/wiki/Movie_palace.

Nickelodeon (Movie Theater) Wikipedia. [Accessed 30 June 2019.] Retrieved from: https://en.wikipedia.org/wiki/Nickelodeon_(movie_theater).

Nickelodeon. Liberal Dictionary. [Accessed 30 June 2019.] Retrieved from: https://www. liberaldictionary.com/nickelodeonnickelodeon/.

Turkish Cinema. Turkish Culture Foundation. [Accessed 28 June 2019.] Retrieved from: http://www.turkishculture.org/performing-arts/film/turkish-cinema-591.htm. 